UNIVERSIDADE DE SÃO PAULO

FACULDADE DE FILOSOFIA LETRAS E CIÊNCIAS HUMANAS

PROGRAMA DE PÓS-GRADUAÇÃO EM LINGUÍSTICA GERAL E SEMIÓTICA

BRUNO OKOUDOWA

MORFOLOGIA VERBAL DO LEMBAAMA

SÃO PAULO

2010 


\section{BRUNO OKOUDOWA}

\section{MORFOLOGIA VERBAL DO LEMBAAMA}

Tese de Doutorado apresentada ao curso de Pós-Graduação em Semiótica e Linguística Geral da Faculdade de Filosofia, Letras e Ciências Humanas da Universidade de São Paulo.

Área de concentração: Semiótica e Linguística Geral

Orientadora: Profa. Dra. Margarida Maria Taddoni Petter

\section{SÃO PAULO}




\section{FOLHA DE APROVAÇÃO}

Bruno Okoudowa

Morfologia Verbal do lembaama

Tese de Doutorado apresentada ao curso de Pós-Graduação em Semiótica e Linguística Geral da Faculdade de Filosofia, Letras e Ciências Humanas da Universidade de São Paulo.

Área de concentração: Semiótica e Linguística Geral

\section{Aprovada em:}

\section{BANCA EXAMINADORA}

Orientadora: Profa. Dra. Margarida Maria Taddoni Petter

Membros da Banca

Prof. Dr.

Instituição:

Assinatura:

Prof. Dr.

Instituição:

Assinatura: 
'Scripta manent. Uerbum volant'

(Palavras escritas ficam. Palavras faladas voam). 
Este trabalho é dedicado

$\mathcal{A}$ todas as minorias cujas línguas ainda não foram transcritas;

A toda a diáspora 6anta;

$\mathcal{A}$ todos aqueles que se interessam pelas línguas africanas em gerale bantas em particular;

Aos meus falecidos pais, Okoudowa Alfonse e Andou Adrienne,

Que me mostraram o caminho da Escola e que estariam felizes com este trabalho;

A meu irmão mais velho Lekogho Jules César "Alandji", meu "Yaaya", que me criou depois da morte dos meus pais;

À minha esposa Iris Helena de Moura Okoudowa, que sempre esteve junto comigo nos momentos mais dificeis;

Aos meus filhos, Bruno Okoudowa Júnior, Andou Adrienne dos Santos Okoudowa, e particularmente ao caçula Odjuani de Moura Okoudowa que vivenciou e sofreu as dificuldades deste trabalho comigo desde o início, que todos eles encontrem neste trabalho suas raízes bantas. 


\section{AGRADECIMENTOS}

À Prof ${ }^{a} \operatorname{Dr}^{\mathrm{a}}$ Margarida Maria Taddoni Petter, pela paciência e pela disposição de ensinar, por sua inestimável orientação e pelo incentivo durante a realização deste trabalho.

À $\operatorname{Prof}^{a} \operatorname{Dr}^{\mathrm{a}}$ Esmeralda Vailati Negrão pela orientação durante nossa discussão no Encontro dos Alunos da Pós-Graduação em Linguística "ENAPOL”, criado por ela.

Aos Professores Doutores Esmeralda Vailati Negrão e Waldemar Ferreira Neto pela discussão durante o exame de qualificação.

À Prof ${ }^{\mathrm{a}}$ Dr $^{\mathrm{a}}$ Maria Célia Lima-Hernandes, pela sua importante ajuda e pela sua amizade.

Aos Professores Doutores Jean Paul Rékanga, Didier S.J.M. Demolin, Jacky Maniacky pela sua ajuda.

Ao Sr. Legnongo-Ndoumba Benjamin pela sua ajuda material.

Ao Departamento de Linguística, em especial à Erica Flávia de Lima, por seu apoio.

Ao Paulo Jefferson e à Dayane Pal, colegas do Grupo de Estudos de Línguas Africanas (GELA) da FFLCH-USP, e à Ester Zuzo pela revisão deste trabalho e pela amizade. 


\section{SUMÁRIO}

INTRODUÇÃO...........................................................................................................1

1 Estudos anteriores sobre a língua lembaama ..................................................2

2 Corpus e Metodologia................................................................................................7

Capítulo I - ESTUDO DAS LÍNGUAS BANTAS.....................................................8

1 Pioneiros da Bantuística......................................................................................................8

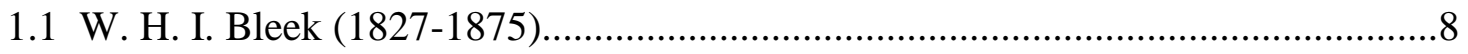

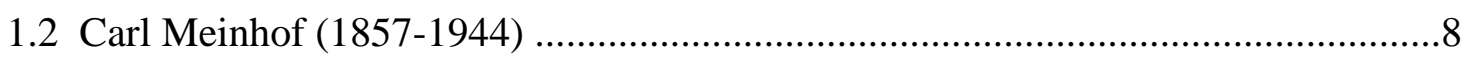

1.3 Malcolm Guthrie (1903-1972) .......................................................................

1.4 Achille E. Meeussen (1912-1978) …………………………………………........

2 As línguas bantas..............................................................................................................11

2.1 Localização das línguas bantas............................................................................11

2.2 Classificação genética das línguas bantas................................................................12

2.3 Características tipológicas das línguas bantas........................................................14

3 Características tipológicas das línguas bantas da floresta........................................19

3.1 Características gerais fonológicas das línguas bantas da floresta..............................20

3.2 Características gerais da morfologia nominal das línguas bantas da floresta............26

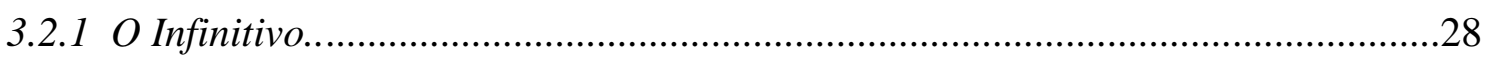

3.3 Características gerais da morfologia verbal das línguas bantas da floresta..............29

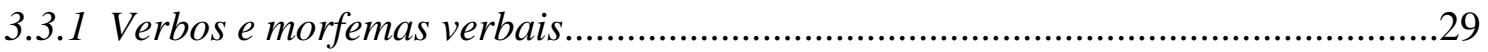

Capítulo II - PRINCIPAIS CARACTERÍSTICAS DA FONOLOGIA

E DA MORFOLOGIA NOMINAL DO LEMBAAMA................................................36

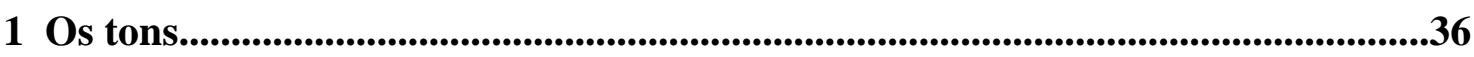

2 As consoantes.....................................................................................................36

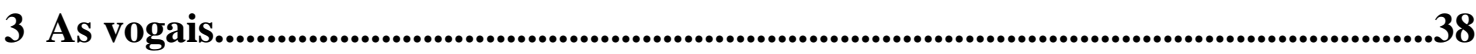

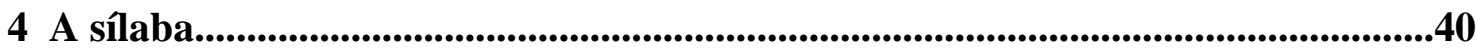

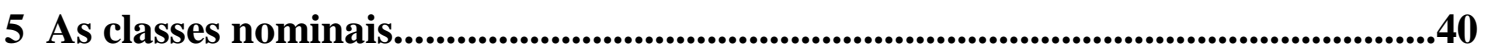

5.1. Organização do quadro 4.................................................................................................43 
Capítulo III - ESTRUTURA DO VERBO EM LEMBAAMA................................45

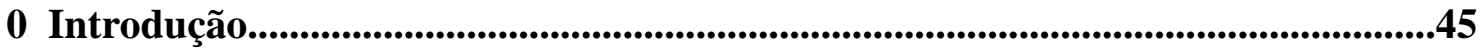

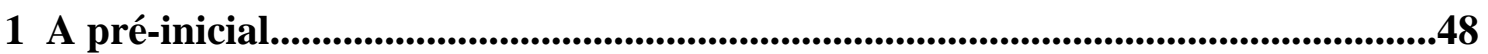

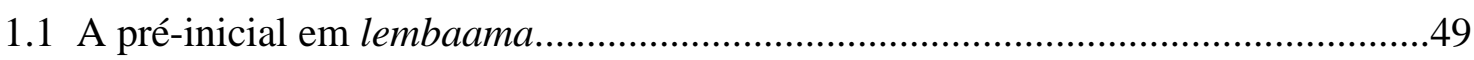

2 A Inicial......................................................................................................................................49

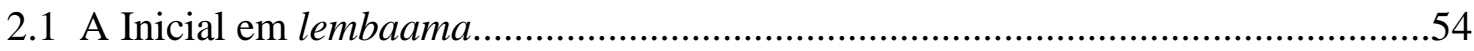

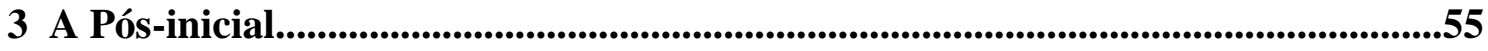

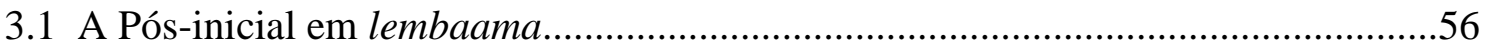

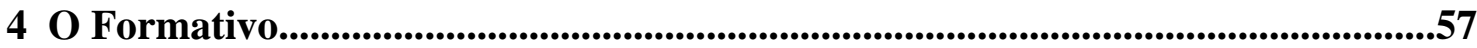

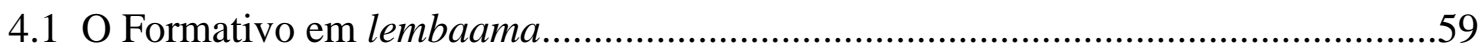

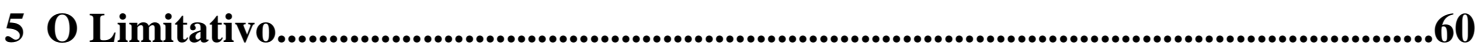

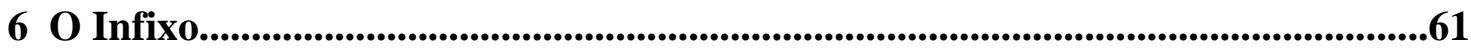

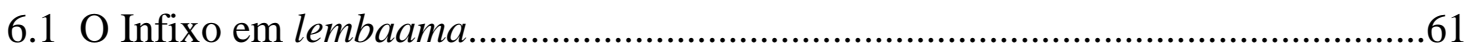

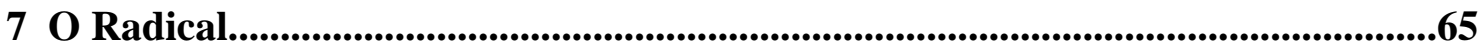

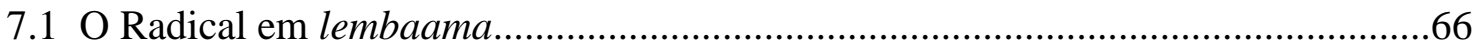

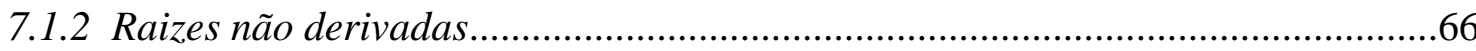

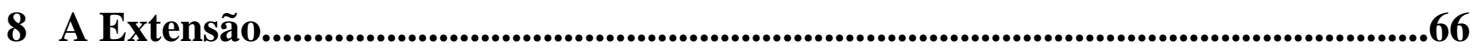

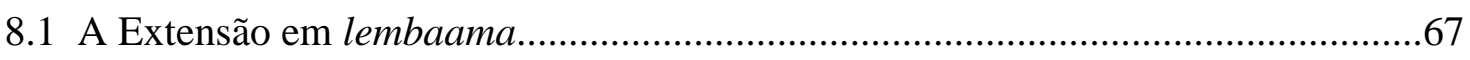

9 A Pré-final............................................................................................................68

10 A Final ou Vogal Final...............................................................................................68

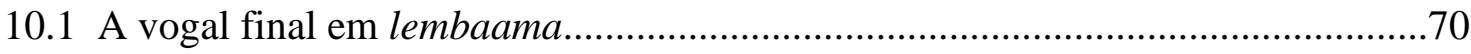

11 A Pós-final..............................................................................................................................72

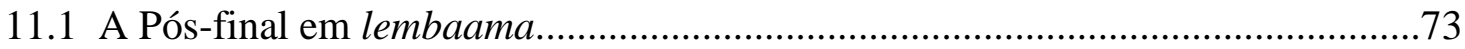

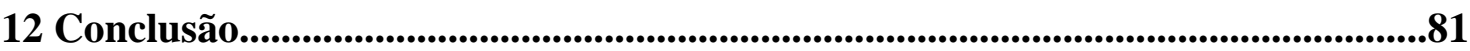

Capítulo IV - A DERIVAÇÃO VERBAL .......................................................84

0 Introdução.........................................................................................................................................84

1 A Transitividade segundo Hopper e Thompson (1980:251-299) .............................84

2 Os sufixos derivativos e a transitividade em lembaama .........................................88

2.1 Sufixos derivativos que distinguem os traços +/- humano......................................98

2.2 Sufixos derivativos que indicam o habitual em lembaama....................................100

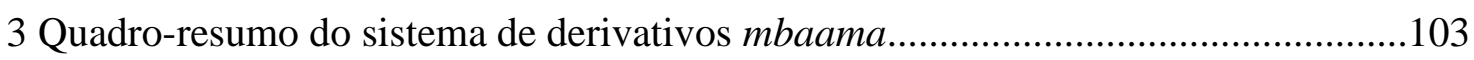

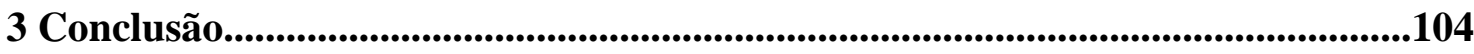


Capítulo V - TEMPO, ASPECTO E MODO EM LEMBAAMA..........................106

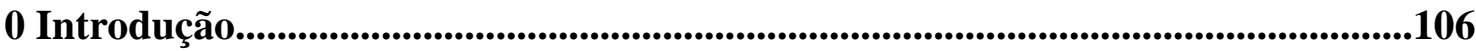

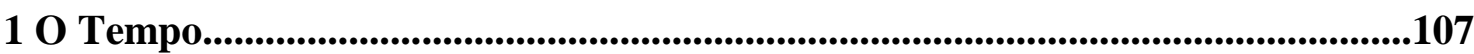

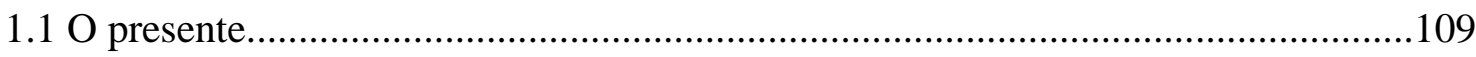

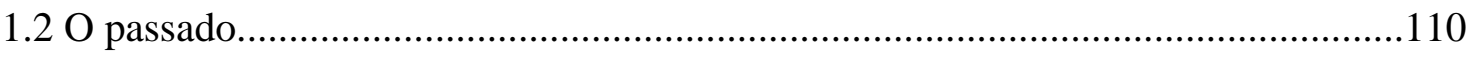

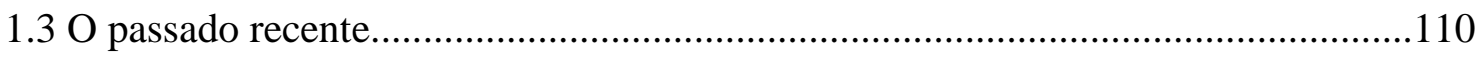

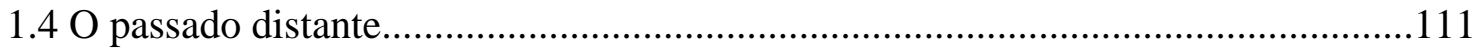

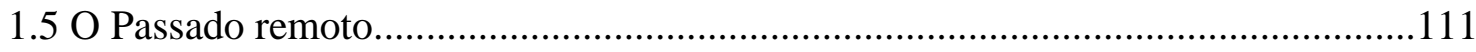

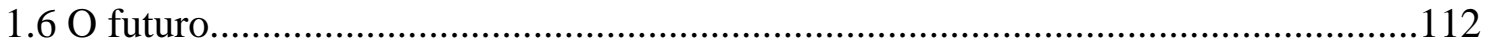

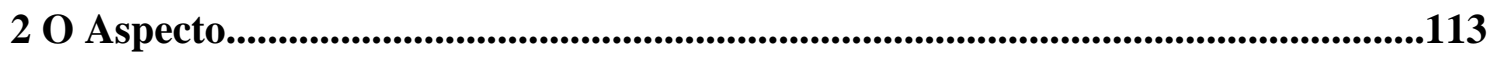

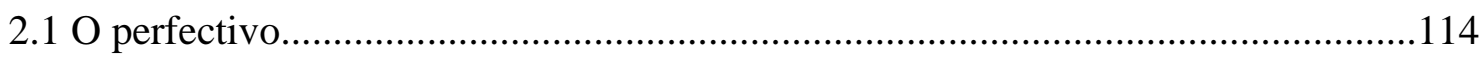

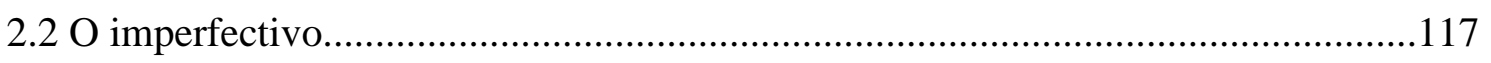

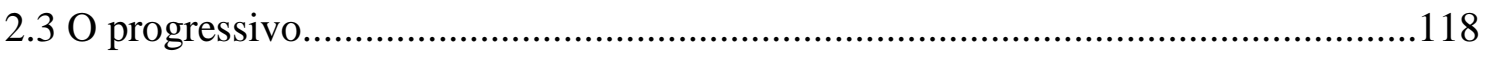

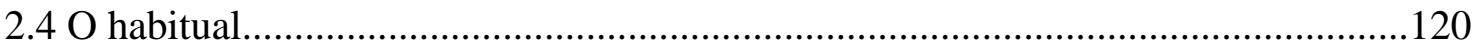

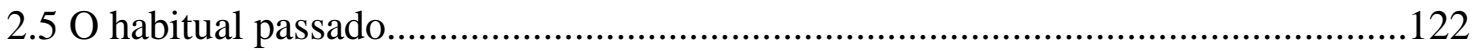

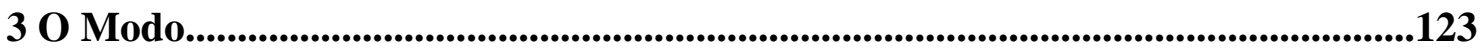

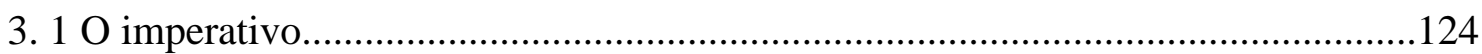

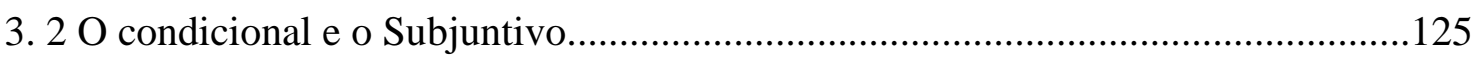

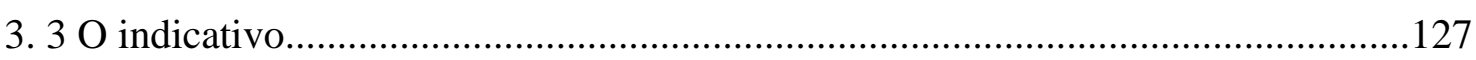

4 Conclusão

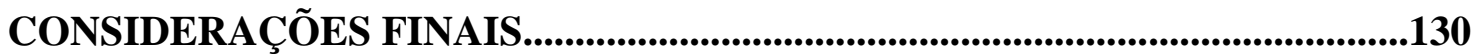

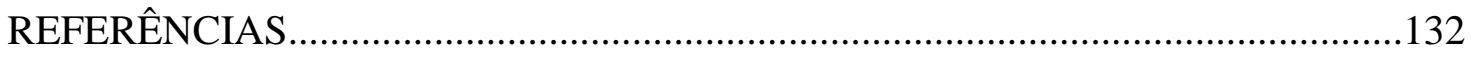

APÊEDICES...........................................................................................................138

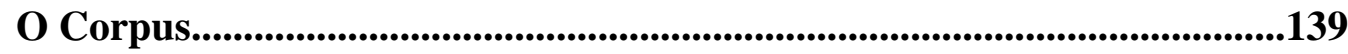

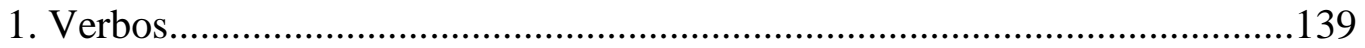

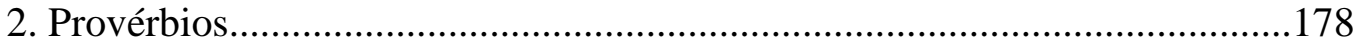

3. Fábula mbaama: O ferreiro e a tartaruga................................................ 183

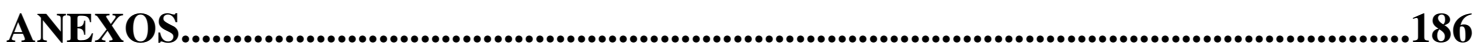

Classificação genética das línguas africanas do tronco Nigero-congolês......... 187

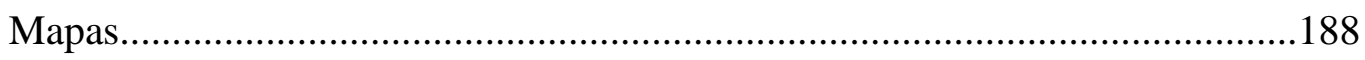


OKOUDOWA. Bruno. Morfologia verbal do lembaama. 2010. 213f. Tese (doutorado) Faculdade de Filosofia, Letras e Ciências Humanas, Universidade de São Paulo, São Paulo, 2010.

\section{RESUMO}

Este trabalho propõe a análise da morfologia verbal do lembaama ${ }^{1}$, que é uma língua do subgrupo banto (da floresta), B.62 (Guthrie, 1971), do grupo Benuê-Congo, do tronco Nigero-congolês. Como esta língua não apresenta nenhum estudo deste gênero, esperase que esta primeira análise possibilite estudos posteriores neste e em outros campos linguísticos. A análise morfológica dos verbos revelou, primeiramente, que a estrutura verbal dessa língua é composta dos seguintes elementos: sujeito, índice do sujeito, negaçãol, marca de Tempo, raiz do verbo, extensão, vogal final ou marca de Aspecto, objeto(s) ou índice do objeto, negação2 que se seguem numa ordem fixa na oração. Constatamos que o índice do objeto, que é geralmente anteposto à raiz do verbo na maioria das línguas bantas, é posposto ao verbo em lembaama. A negação, por sua vez, é representada pelo morfema descontínuo composto por dois elementos: $k a$ - (negação1) e -ní (negação2). Sendo que na estrutura verbal, $k a$ - aparece depois do índice do sujeito (à esquerda da raiz do verbo) e -ni aparece depois do índice do objeto (à direita da raiz do verbo), é o último elemento da estrutura do verbo. Ao estudar a derivação verbal em lembaama, constatamos que a estrutura das extensões desta língua difere daquela encontrada nas outras línguas bantas pelo fato do lembaama ter acrescentado à estrutura -VC- preexistente no protobanto, estruturas do tipo -C-, -CV- e -CVC-. A extensão mais comum e mais fácil de ser reconhecida nessa língua é aquela que marca o habitual, tanto no presente (-ag-) como no passado (-ig-). O estudo dos sufixos derivativos do lembaama revelou também a existência de uma correlação entre o valor gramatical e o valor semântico das extensões. Vimos que seres humanos e animados são envolvidos em orações que apresentam uma transitividade alta. $\mathrm{O}$ estudo da transitividade mostrouse, ainda, como uma noção fundamental nessa língua porque distingue ações e estados, por exemplo. Quanto à análise das categorias Tempo, Aspecto e Modo (TAM), essa língua evidenciou três tempos: um presente que não tem marcas e que se confunde com o presente pontual, o progressivo e o futuro. Dois futuros: um mais próximo, sem

\footnotetext{
${ }^{1}$ Esta língua é também conhecida oficialmente no Gabão como obamba.
} 
marcas, que se confunde com o presente pontual e o progressivo; outro, mais distante, marcado pelo verbo auxiliar odze 'ir'. Três passados: um recente, marcado pelo morfema mí- de tom alto e anteposto ao radical do verbo; um distante, marcado pelo morfema máá- de tom alto e anteposto ao radical do verbo; um remoto, expresso pela junção do verbo auxiliar - $k i$ 'estar' e o morfema do passado mí-. Assim, contrariamente aos morfemas de Aspectos, os morfemas de Tempo são sempre antepostos ao radical do verbo. É o caso dos dois morfemas que marcam os passados recente e distante. Há dois aspectos: o perfectivo, marcado pela vogal final -í; o imperfectivo, sem marca específica. A análise dos tempos e dos aspectos revelou que o Aspecto é mais fundamental em lembaama. O estudo dos modos permitiu identificar três: o imperativo, o condicional e o indicativo.

Palavras-chave: lembaama, línguas bantas, línguas africanas, morfologia verbal, morfossintaxe. 
OKOUDOWA. Bruno. Morphology of lembaama verbal system. 2010. 213f. Dissertation (PhD Course) Faculdade de Filosofia, Letras e Ciências Humanas, Universidade de São Paulo, São Paulo, 2010.

\begin{abstract}
This work proposes an analysis of the verbal morphology of Lembaama (B62) according to Guthrie (1971). Officially called Obamba in Gabon, Lembaama is a Bantu language of the forest, from the Benue-Congo group and Niger-Congo phylum. As far as we know, this language has yet to receive a detailed study. It should be noted that Lembaama shows some interesting features. Indeed, the verbal morphology analysis shows that a single inflected verb contains the following elements: subject, subject marker, negative1, Tense marker, root, extension, Final Vowel or Aspect marker, negative2 occurring in a fix order in a sentence. The object marker comes after the root. Negation consists of a discontinuous morpheme: $k a \ldots n i$. $K a$ - is placed before the root (by the left) and -ní occurs after the root (by the right) being the last element of this structure. The verbal derivation study reveals the following structure of Lembaama extensions: -C-, -CV-, -VC- and -CVC-.The habitual marker ag- being the commonest extension. This study also highlights the existence of a correlation between the grammatical value and the semantic value of extensions. Hence, human and animate beings are evoked in clauses with higher transitivity than things. Therefore, transitivity is fundamental in Lembaama, as it can distinguish actions from states, for example.

Tense, Aspect and Mood study defines three Tenses. First, there is a present that, because it is used without tense marker, can be merged with near future or with progressive. Then, we note two future tenses: a near future (F1) occurring without mark and a distant future (F2) marked by the auxiliary verb odze 'go'. Finally, we count three past tenses: a recent (P1) marked by mí- with a high tone; a distant (P2) marked by máá- with a high tone too, and a remote past (P3) marked by ki 'be', an auxiliary verb with high tone and mí-, the recent past marker, both coming before the root (by the left). Thus, Tense marker morphemes are always placed before the root (by the left) and Aspect markers occur after the root (by the right). This analysis highlighted two Aspects: a perfective marked by the Final Vowel -í; an imperfective without a specific mark. Tense and Aspect analysis allows to conclude that Aspect is more fundamental than Tense in this language. Concerning Mood, the analysis revealed three: imperative, conditional and indicative.
\end{abstract}

Keyword: Lembaama, Bantu languages of the forest, African languages, verbal morphology, morpho-syntax. 


\section{LISTA DE QUADROS}

Quadro1: Quadro fonológico das consoantes................................................................37

Quadro2: Quadro fonológico das vogais breves........................................................38

Quadro3: Quadro fonológico das vogais longas.........................................................38

Quadro4: Classes nominais do lembaama .................................................................42

Quadro5: Gêneros e classes nominais do lembaama .......................................................44

Quadro6: Pronomes pessoais do lembaama.............................................................77

Quadro7: Critérios da transitividade segundo Hopper \& Thompson.....................85

Quadro8: Sistema dos derivativos mbaama................................................................104

Quadro9: imperativo do verbo okúná 'plantar'...............................................124

\section{LISTA DE MAPAS}

MAPA 1- Mapas das línguas da grande família Nigero-congolesa........................188

MAPA 2- Mapa que apresenta o grupo Benuê-congo e o subgrupo banto............189

MAPA 3- Mapa das línguas bantas classificadas em grupos................................190

MAPA 4- Mapa das principais línguas bantas da floresta.....................................191

MAPA 5- Mapa das principais línguas do Gabão........................................................192 


\section{ABREVIAÇÕES E SIGNOS}

\begin{tabular}{|c|c|}
\hline 1-12 & Classe 1-12 \\
\hline $1 P$ & Primeira pessoa do plural \\
\hline $\mathbf{1 S}$ & Primeira pessoa do singular \\
\hline A & Tom alto \\
\hline Adj & Adjetivo \\
\hline ANT & Anterior \\
\hline Asp & Aspecto \\
\hline Aux & Verbo auxiliar \\
\hline B & Tom baixo \\
\hline $\mathbf{C}$ & Consoante \\
\hline Caus & Extensão Causativa (indica a causa) \\
\hline $\mathrm{Cl}$ & Classe \\
\hline Con & Conectivo \\
\hline CV & Consoante + Vogal \\
\hline DEM & Demonstrativo \\
\hline Ext & Extensão \\
\hline F1 & Futuro1 \\
\hline Foc & Foco \\
\hline Fut & Futuro \\
\hline Ger & Gerúndio \\
\hline Hab & Habitual \\
\hline Habp & Habitual Passado \\
\hline Imp & Imperativo \\
\hline Inf & Infinitivo \\
\hline Inst & Extensão Instrumental (indica o instrumento) \\
\hline IO & Índice do Objeto \\
\hline IPFV & Imperfectivo \\
\hline IS1 & Índice do Sujeito da classe1 \\
\hline LBs & Línguas Bantas \\
\hline $\mathbf{L B F}$ & Línguas Bantas da Floresta \\
\hline L1 $(2,3,4)$ & Linha $1(2,3,4)$ \\
\hline
\end{tabular}




\begin{tabular}{|c|c|}
\hline Loc & Locativo \\
\hline MT & Marca de Tempo \\
\hline $\mathbf{N}$ & Nasal ou Nome (depende do contexto) \\
\hline NC & Consoante pré-nasalizada (Nasal+Consoante) \\
\hline NEG & Negação \\
\hline Neg1 & Primeiro elemento da negação \\
\hline Neg2 & Segundo elemento da negação \\
\hline NV & Nasal + Vogal \\
\hline O1,2.../Obj & Objeto1,2.../Objeto \\
\hline $\mathbf{P}$ & Plural \\
\hline P1,2,3.../Pas & Passado 1, 2, 3.../Passado \\
\hline PA & Prefixo Adjetival (Prefixo do Adjetivo) \\
\hline PFTV & Perfectivo \\
\hline PN & Prefixo Nominal \\
\hline Pos & Possessivo \\
\hline Pré-f & Pré-final \\
\hline Prep & Preposição \\
\hline Pres & Presente \\
\hline Prog & Progressivo \\
\hline Pscl & Extensão Posicional (indica a posição) \\
\hline PSV & Extensão Passiva (indica a forma passiva do verbo) \\
\hline PV & Prefixo verbal \\
\hline Rad & Radical \\
\hline Refl & Reflexivo \\
\hline Rel & Relativo \\
\hline Rel5 & Relativo da Classe 5 \\
\hline Rel3s & Relativo da terceira pessoa do singular \\
\hline RFL & Extensão Reflexiva (indica a reflexividade) \\
\hline Rst & Extensão Resultativa (indica o resultado) \\
\hline $\mathbf{R V}$ & Raiz Verbal (Raiz do verbo) \\
\hline SBJ & Subjuntivo \\
\hline SVO & Sujeito, Verbo, Objeto \\
\hline TA & Transitividade Alta \\
\hline
\end{tabular}




$\begin{array}{ll}\text { TAM } & \text { Tempo, Aspecto e Modo } \\ \text { TA } & \text { Transitividade alta } \\ \text { TB } & \text { Transitividade Baixa } \\ \text { Tr } & \text { Transitivo } \\ \text { V } & \text { Vogal } \\ \text { VF } & \text { Vogal Final } \\ + & \text { Junção } \\ \text { II } & \text { Limite entre orações } \\ / & \text { Limite entre lexemas independentes } \\ - & \text { Limite entre morfemas } \\ \varnothing- & \text { Prefixo zero }\end{array}$




\section{INTRODUÇÃO}

O lembaama é uma língua do subgrupo banto (da floresta), B.62 (Guthrie, 1971), do grupo Benuê-Congo, do tronco Nigero-congolês. Esta língua é oficialmente conhecida no Gabão como Obamba, sendo também chamada Mbede, Mbete ou Mbama pelos linguistas que a estudaram. A língua lembaama estudada aqui é falada no sudeste do Gabão na província do Haut-Ogooué por cerca de 24.800 habitantes, segundo Lewis (2009).

Os falantes da língua lembaama denominam-se ambaama (plural) ou ombaama (singular), mas são oficialmente chamados, no Gabão, de "obamba" (invariável), termo que corresponde a uma simplificação que ocorreu no período colonial e que foi retomada pela administração gabonesa do termo ombaama (Andjembé, 1999).

Segundo o mesmo autor, o povo mbaama, desde suas origens, compreende sete clãs, hoje divididos entre a República do Gabão e a República do Congo. São eles: Serê, Ampiini, Nguali, Lessia, Lolo-aku, Ngaami e Oba.

O clã serê, que se considera como o primeiro de todos, localiza-se principalmente em Kelle, no Congo, e em Okondja, no Gabão. O clã Ampiini cobre, no Gabão, a região de Franceville, cuja maior parte se encontra no município de Lekabi-Lewolo. Ele se encontra também em Okondja. No Congo, ele se localiza nas cidades de Zanaga e Sibiti. O clã Nguali reside nas seguintes cidades: Franceville, Okondja, Moanda, Munana e Lasturville, no Gabão; em Kelle, Sibiti e Zanaga, no Congo. Quanto ao clã Lessia, este tem como berço a cidade de Kelle no Congo. O clã Lolo-Aku se localiza em Franceville e seus arredores. O clã Ngaami se encontra nas cidades de Abumi e Okondja no Gabão; por fim, o clã Oba está presente em Kelle e Lewo no Congo.

Segundo Adam (1971), os ambaama usam vários nomes diferentes dependendo da região onde moram ou dependendo do nome atribuído pelos autores que os estudaram. Assim, fala-se de mbeti, umbete, ambéré, embiri, etc. para designar o mesmo povo.

Trata-se de um povo que pratica, por tradição, o culto dos antepassados e a religião cristã por influência da colonização francesa. O povo mbaama hoje reside tanto no meio rural como no meio urbano. Aquele que reside no meio rural (no interior do país) vive nos vilarejos localizados, de uma parte, entre as cidades de Franceville e Abumi passando pela cidade de Akiéni: entre as cidades de Akiéni e Okondja e de Okondja e Abumi. Por outro lado, os ambaama do meio rural se encontram nos vilarejos entre as Cidades de Franceville e 
Okondja. Há, ainda, relatos de que há ambaama em alguns vilarejos da província do OgoouéLolo ${ }^{1}$, que é uma província vizinha do Haut-Ogooué.

Sendo um povo essencialmente da floresta (como o nome do clã ampiini 'florestas' já o diz), o povo mbaama vive da agricultura, da caça, da pesca e da coleta. Os ambaama que residem no meio urbano, na sua maioria, vivem nas cidades como Libreville: capital do Gabão; Franceville (capital provincial do Haut-Ogooué), Moanda (cidade industrial do HautOgooué) e Okondja (cidade principal dos ambaama). Esse povo vive das atividades econômicas que a vida moderna dessas cidades oferece. Porém, os dois grupos do povo mbaama estão sempre em contato, principalmente durante as férias daqueles que trabalham e estudam nas cidades. Não existe nenhum poder central para todo o grupo étnico mbaama. Cada vilarejo tem seu chefe e vive relativamente de uma maneira autônoma sob a autoridade da administração provincial.

As atividades do vilarejo obedecem ao ritmo das quatro estações do ano no país que são: a grande estação de chuvas (de março a maio), a grande estação de seca (de julho a agosto), a pequena estação de chuva (de setembro a novembro), e a pequena estação de seca (de dezembro a fevereiro).

Para efeitos de recorte metodológico, esta tese tomará como objeto central o lembaama falado na cidade de Okondja, no Gabão, especificamente na aldeia Entogho ou Obagha-Mpari (um vilarejo que faz parte do agrupamento de vilarejos chamado Otala, no departamento de Lekoni-Lekori) de onde o autor é oriundo (apesar de ter nascido na cidade de Moanda).

\section{Estudos anteriores sobre a língua lembaama}

Alguns estudos já haviam sido feitos sobre o lembaama, no século passado (século XX), pelos missionários Adam e Biton (1969) e pelos estudiosos Blanchon e Alihanga (1992).

(i) O estudo de Adam e Biton é o primeiro e único dicionário escrito sobre essa língua em francês: DICTIONNAIRE DUMU-MBEDE-FRANÇAIS (dicionário ndumu-mbede-francês). Esse dicionário é acompanhado de um léxico sobre a flora: PETITE FLORE (pequena flora) e de uma gramática: GRAMMAIRE. Essa obra é, portanto, dividida nessas três partes que

\footnotetext{
${ }^{1}$ No Gabão, os nomes das províncias seguem os dos rios. Portanto Ogooué e Lolo são rios. Sendo Ogooué o principal deles. Ele se joga no Oceano Atlântico. Haut-Ogooué se refere à parte alta do rio Ogooué.
} 
totalizam 656 páginas e foi publicada em 1969 pela imprensa Saint-Paul na cidade de Bar-leDuc no departamento de Meuse, na França;

(ii) Uma outra obra, a cuja referência não podemos nos furtar, é a coletânea de provérbios, adivinhas e fábulas mbede (FOLKLORE DU HAUT-OGOOUÉ: PROVERBES, DEVINETTES, FABLE MBEDE). Trata-se de uma obra de 360 páginas, da autoria do arcebispo de Libreville J. J. Adam ${ }^{2}$, publicada em 1971 pela imprensa Saint-Paul na cidade de Issy-les Moulineaux no departamento de Hauts-de-Seine, na França.

Apesar da sua importância do ponto de vista histórico, esses estudos feitos pelos missionários propiciam ao leitor uma visão pouco precisa da língua, já que esses autores tinham outros objetivos e não dispunham dos conhecimentos de que dispomos hoje, por exemplo, sobre a classificação dessa língua e sobre a anotação dos seus tons.

(iii) Quanto ao estudo realizado por Blanchon e Alihanga (1992), embora este último estudioso seja falante nativo do lembaama, limitou-se a algumas anotações para uma tentativa de definição das classes nominais dessa língua: trata-se do artigo intitulado 'Notes sur la morphologie du lempiini de Eyuga'(Notas sobre a morfologia do lempiini de Eyuga ${ }^{3}$ ), publicado em 1992, na Revista Pholia, volume 7, pelo Laboratório de Fonética e Linguística Africana do Centro de Pesquisas Linguísticas e Semiológicas da Universidade Lumière Lyon 2, na cidade de Lyon, na França. Nesse trabalho, os autores identificaram 15 classes nominais em lempiini, contra as 7 descobertas por Adam (1969) e contra as 12 que definimos em trabalho anterior (cf. Okoudowa, 2005: 32). Um aspecto importante do trabalho de Blanchon e Alihanga é que, no mesmo quadro, além das classes nominais, apresentam também os demonstrativos que vão com cada classe, assim como os emparelhamentos de cada classe. Porém, assim como no trabalho predecessor, não há qualquer anotação sobre tons ${ }^{4}$. Pelo menos, diferentemente do que ocorreu com Adam, concordamos com Blanchon e Alihanga sobre a presença de alomorfes ou variantes nos prefixos nominais de algumas classes: por exemplo, os prefixos $o$-, zero $(\varnothing-), m u$ - que se torna $m w$ diante de uma vogal na classe $1 ; a$ - e $b a$ - na classe $2 ; \varnothing$ - e $N$-respectivamente nas classes 9 e 10 . Por fim, o nosso quadro das classes nominais apresenta, além dos prefixos do nome, o prefixo do adjetivo, o conectivo, o índice do sujeito e o índice do objeto acompanhados de exemplos.

Em 2005, iniciamos o estudo dessa língua com a nossa Dissertação de Mestrado intitulada Descrição Preliminar de Aspectos da Fonologia e da Morfologia do Lembaama.

\footnotetext{
${ }^{2}$ Nasceu em 1904 em Wittenheim na França e faleceu em 1981 em Franceville no Gabão.

${ }^{3}$ Trata-se do lempiini, dialeto do lembaama, falado no vilarejo de Eyuga que é localizado entre as cidades de Okondja e Abumi. Esse é o dialeto falado pelo autor deste trabalho.

${ }^{4}$ Segundo os autores, a anotação de tons não foi publicada por não ter sido suficientemente verificada.
} 
(OKOUDOWA, 2005). Os objetivos específicos desse estudo foram: fazer um inventário do sistema fonético; descrever fonologicamente os sistemas consonantal e vocálico; analisar alguns fatos do sistema tonal e descrever a estrutura morfológica dos nomes dessa língua. $\mathrm{O}$ estudo em questão apresenta alguns aspectos da língua que ainda não tinham sido estudados até então, como o fenômeno da nasalização das vogais; a análise da estrutura da sílaba e de alguns fenômenos fonológicos como a semivocalização, a palatalização, o apagamento vocálico, a elisão, dentre outros. Há ainda muitos não estudados em lembaama, como a morfologia verbal e a sintaxe. No que diz respeito à morfologia verbal só existe a gramática de Adam e Biton (1969), uma gramática geral da língua, o que significa que não se fez nenhum trabalho especializado sobre o tema.

Na maioria das línguas, o verbo tem uma flexão consideravelmente mais complexa do que qualquer outra categoria gramatical da língua. De fato, se para os nomes, a flexão se dá em termos de gênero e número, caso das línguas latinas, por exemplo, para as línguas bantas, a flexão se faz em número. Para o verbo, a flexão é muito mais produtiva do que a dos nomes e se manifesta sob a forma de tempo, aspecto e modo (TAM).

Nas línguas bantas, em especial, a flexão verbal se organiza de modo aglutinante. Línguas de morfologia aglutinante ou 'línguas aglutinantes' diferenciam-se das línguas de morfologia flexional, pelo fato de que, naquelas línguas, o alinhamento de morfemas é maior, sendo que estes são relativamente transparentes, com uma forma (sem nenhum ou com poucos alomorfes, frequentemente condicionados) e um significado; enquanto nas línguas flexionadas, os morfemas são opacos com muitos alomorfes com significados amalgamados (NURSE, 2008, p. 28).

As línguas bantas são também chamadas de 'Verby languages', isto é, a sua morfologia aglutinante expressa pela flexão o que outras línguas expressam lexicalmente ou sintaticamente (NURSE; PHILIPPSON, 2008, p. 21). Para esses autores, um único verbo é originalmente constituído por 11 'elementos' centrados em uma raiz. Os autores advertem que 'elementos' não significam necessariamente morfemas. À esquerda da raiz do verbo, encontramos prefixos que expressam o relativo, a negação, o sujeito, o tempo, o aspecto, e muitas outras categorias como o condicional, o foco, o objeto etc. À sua direita, encontramos extensões com flexão que expressam aspectos, modos e outras categorias. Muitas línguas bantas ainda têm essa estrutura ou uma estrutura semelhante. Umas modificaram-na. Outras alongaram ou reduziram-na. A posição da extensão permite a ocorrência de vários morfemas. Em algumas línguas bantas, a posição da vogal final permite a ocorrência de três morfemas. Em poucas delas, a posição do prefixo principal que indica o tempo e o aspecto pode ter 
vários morfemas. Vejamos o exemplo do quinande (DJ42) citado por Nurse \& Philippson (2003: 9) sem glosa (sem tradução de cada morfema):

(1) tu-né-um-ndi-syá-tá-sya-ya-ba king-ul-ir-na-is- i- á kyô

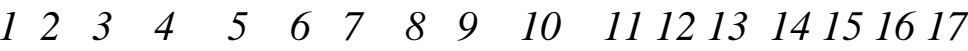

'Nós vamos tornar isso possível mais uma vez para que eles abram isso uns aos outros'

O fato de a maioria das línguas africanas ter poucos adjetivos qualificativos como observam muitos estudiosos como Dimmendaal (2000, p. 171), Creissels (2000, p. 249) e Watters (2000, p. 195-196) faz com que muitas delas usem verbos para expressar o que é expresso por adjetivos em outras línguas do mundo.

Nas línguas africanas, nomes e verbos são classes de palavras muito importantes. Línguas africanas tendem a usar verbos frequentemente, mais frequentemente do que línguas como o inglês e outras línguas europeias. Muitos adjetivos descritivos nas línguas europeias são expressos por verbos nas línguas africanas. Frases como 'ele é grande’ e 'ela é bonita' são frequentemente expressas por um verbo no lugar de 'ser + adjetivo' como em 'é + bonito(a)'.

Vejamos os seguintes exemplos ${ }^{5}$ em que 'vermelho' em (2) e 'doente' em (3) são tratados como verbos:

(2) Aghem, Grassfield Bantu, Benue-Congo, Niger-Congo (Hyman 1979:32 )

$\begin{array}{ll}\text { nwín fí-bánà nò } & \text { nón } \\ \text { pássaro 1-vermelho:Pres } & \text { FOC } \\ \text { 'o pássaro é vermelho' } & \end{array}$

(3) Ngiti, Lendu, Central Sudanic, Nilo-Saharan (Kutsch Lojenga 1994:228)

mǎ m-àndi

$1 \mathrm{P}$ IS- doente:Pres

'Estamos doentes'

Verbos também podem ser usados onde o inglês, por exemplo, usaria advérbios (como frequentemente, ainda, ainda não, novamente) e conjunções (como e então)' (Watters, 2000: 195-196). No exemplo (4) a seguir, na língua Ejagham, o verbo 'continuar' tem o significado de ‘ainda' em (a) e de ‘ainda não' em (b).

\footnotetext{
${ }^{5}$ Simplificamos a glosa desses exemplos para facilitar a compreensão.
} 
(4) Ejagham, Ekoid Bantu, Benue-Congo, Niger-Congo (Watters, 2000:196)
(a) à-nyə́nè
à-chòr-á
3s:PFTV-continuar 3s:Hab-falar-IPFV
'Ela ainda está falando'
(b) à-nyónè
á-kà-chǒt
'Ela ainda não falou'
3s:PFTV-continuar 3s-NEG-falar

É preciso reconhecer que ainda há muito para investigar com relação aos verbos nas línguas africanas em geral e bantas em particular. Fenômenos como tons e foco, por exemplo, precisam de mais descrições já que eles têm uma importância capital nessas línguas. Isso nos ajudará a ter uma melhor compreensão das línguas africanas e contribuir com a (re)formulação de teorias na Linguística Geral. O que ainda não é o caso:

\begin{abstract}
Em particular, muitos mecanismos gramaticais encontrados nas línguas africanas, por exemplo o fenômeno do foco através da morfologia verbal, põe frequentemente em jogo variações das formas do verbo - (ver Creissels, 1996) - mas infelizmente, a proporção das línguas africanas que têm uma boa descrição da morfologia tonal do verbo é pequena. Portanto, um melhoramento na descrição das línguas africanas é uma condição para melhorar o nosso entendimento da estrutura das línguas africanas, e consequentemente uma melhor contribuição da tipologia das línguas africanas na lingüística geral (CREISSELS, 2000, p. 258).
\end{abstract}

O trabalho de Larry M. Hyman e John R. Watters sobre o foco auxiliar 'Auxiliary focus' publicado em dezembro de 1984 pela revista Studies in African Linguistics (volume 15, número 3), é um excelente exemplo de trabalho sobre o foco na língua aghem (língua banta do grupo Grassfields falada na república dos Camarões).

O fato de que nas línguas bantas o verbo pode incorporar muitas informações e que ainda há, relativamente, poucos estudos sobre essas línguas estimularam-nos a optar pelo estudo desta categoria em lembaama. Assim, o objetivo geral deste estudo é fazer uma análise de aspectos da morfologia verbal do lembaama. Para tanto, os seguintes objetivos específicos orientam os passos da pesquisa:

1. Apresentar os estudos bantuístas e características gerais das línguas bantas e, especificamente, das línguas bantas da floresta;

2. Apresentar a estrutura geral do verbo banto e descrever a estrutura do verbo em lembaama;

3. Analisar os componentes da estrutura verbal;

4. Analisar as marcas de tempo, aspecto e modo em lembaama. 
Para desenvolver nossa proposta, em primeiro lugar, situamos nosso estudo no conjunto dos trabalhos desenvolvidos sobre as línguas bantas. Para tanto apresentamos brevemente os pioneiros da bantuística e, a seguir, tratamos das línguas bantas, suas características gerais e destacamos as principais características das línguas bantas da floresta. Em seguida, antes de entrar propriamente no estudo da morfologia verbal em lembaama, fazemos uma síntese da fonologia e da morfologia nominal dessa língua, para que se possa acompanhar melhor as análises que se seguirão. Na terceira parte, estudaremos a estrutura geral do verbo banto e do lembaama, com destaque para a análise das extensões verbais e da transitividade no lembaama e, por fim, descreveremos as diferentes marcas de tempo, aspecto e modo nessa língua.

\section{Corpus e Metodologia}

Os dados que compuseram o corpus sob análise foram oriundos de fontes distintas: uma parte foi constituída com base no conhecimento do autor como falante nativo. Elaboramos um corpus contendo cerca de 400 verbos (separados pelo critério da transitividade); 29 provérbios e uma fábula. Consultamos, quando foi necessário, o corpus da Dissertação de Mestrado (OKOUDOWA, 2005), a coletânea de provérbios, adivinhas e fábulas Mbede de Adam (1971) e, por fim, o dicionário de Adam e Biton (1969).

As análises empreendidas inspiram-se no trabalho de africanistas bantuístas, principalmente. Desta forma, seguimos a tradição bantuista representada por Bleek, Meinhof, Guthrie (1948, 1967 e 1971), Achille E. Meeussen (1959-67), Nurse e Philippson (2003) e Nurse (2008), e em alguns momentos foi seguido o modelo de análise proposto por Denis Creissels (2004 e 2006) para as línguas negro-africanas, especialmente a língua tsuana, língua banta falada no Botsuana. Em alguns tópicos específicos de análise buscamos fundamentação teórica em linguistas não africanistas. Assim, para o estudo da transitividade, seguimos o trabalho de Hopper e Thompson (1980: 251-299) e para o estudo do tempo a análise de Fiorin (1996 e 2003), no seu trabalho sobre as categorias enunciativas segundo a visão de Benveniste. 


\section{Capítulo I - ESTUDO DAS LÍNGUAS BANTAS}

\section{Pioneiros da bantuística}

1.1 W. H. I. Bleek (1827-1875)

A palavra banto foi usada pela primeira vez por Bleek, que pode ser considerado o pioneiro e fundador do estudo comparativo das línguas bantas. De fato, seguindo contribuições de outros estudiosos, principalmente de H. Lichtenstein, Bleek (1856) reconheceu não só a unidade das línguas bantas e também sua relação com as grandes famílias Nigero-congolesa e Cordofaniana.

Sua maior obra é intitulada Comparative grammar of south african languages (186269), em que, a partir da comparação de várias línguas do sul da África, constata pontos de semelhanças importantes. Justamente por isso as chamou de línguas bantas: $b a$ - (prefixo nominal da classe 2) e -ntu (raiz que significa 'pessoa'); assim, banto quer dizer 'pessoas'. Nessa obra, Bleek também faz uma comparação tipológica entre 'Bâ-ntu' e 'Hottentot' (da família lingüística Coissan). O estudo de Bleek, além de descobrir a relação entre as línguas bantas, revelou sua morfologia nominal, definindo e enumerando suas classes nominais. Essa enumeração serve de exemplo aos bantuístas até hoje (cf. NURSE; PHILIPPSON, 2003, p. 144; OKOUDOWA, 2005, p. 29).

\subsection{Carl Meinhof (1857-1944)}

O método comparativo aplicado ao estudo do Indo-Europeu foi trazido para o estudo das línguas bantas por Carl Meinhof, que publicou a sua obra Comparative phonology em 1899. Uma versão inglesa foi publicada em co-autoria com Van Warmelo em 1932. O volume complementar Comparative grammar foi lançado logo depois, em 1906.

Quando Meinhof começou esse trabalho, as linhas gerais das línguas bantas já eram conhecidas como as conhecemos hoje, razão por que partiu de conhecimentos já organizados sobre uma pequena série de línguas bem conhecidas à época; ainda assim, sua contribuição foi significativa, pois reconstruiu o sistema de sons comum a essas línguas. Foi uma operação bem sucedida até então. As principais correções foram feitas apenas sobre a série das suas 
duas palatais $* \underline{t} \quad \underline{l}$ e $* \underline{k} \quad X$ para $*_{c} \quad j$; o tom e o comprimento das vogais também foram acrescentados.

Se seu trabalho de reconstrução da morfologia das línguas bantas continua válido, em suas linhas gerais, até hoje, o caráter pioneiro das reconstruções do léxico das línguas bantas não foi menos relevante, ainda que tenha sido alvo de revisão por seus estudantes e colegas, principalmente por Dempwolff e Bourquin. Sua importância para o cenário das pesquisas linguiísticas é tão grande que até hoje todo linguista que tenha que realizar trabalhos de campo com gravações, análises e descrições de línguas bantas toma seus dois principais livros como referência.

Muitos livros foram escritos sobre línguas bantas, principalmente por missionários que seguiram as diretrizes de Meinhof acerca dos estudos bantos durante a primeira metade do século XX. Na África do Sul, por exemplo, sua abordagem foi seguida e desenvolvida por C. M. Doke e seus estudantes.

Na segunda metade do século XX, dois nomes destacam-se na história da linguística banta: Malcolm Guthrie e Achille E. Meeussen (Nurse \& Philippson, 2003: 144).

\subsection{Malcolm Guthrie (1903-1972)}

Guthrie foi professor de línguas bantas na Escola dos Estudos Africanos e Orientais em Londres (School of Oriental and African Studies). Como linguista, foi um autodidata que desenvolveu seus próprios e rigorosos métodos idiossincráticos para comparar as línguas bantas. Seu grande projeto começou com a obra The classification of the bantu languages (1948), no qual ele tentou definir a série de línguas que iriam ocupá-lo para o restante da sua vida, sem pressupor o parentesco histórico entre elas. Esse livro contém também a primeira versão da famosa classificação das línguas bantas por 'zonas' geográficas (cf. Mapa em anexo).

A famosa obra de Guthrie intitulada Comparative Bantu é publicada durante os anos 1967 e 1971. O primeiro volume contém os detalhes do seu método e o registro de suas convicções; o terceiro e o quarto volumes são belas compilações de seus dados organizados em cerca de 2.500 'séries comparativas', cada uma representando um conjunto de palavras ou de morfemas em línguas diferentes ligados por correspondências sonoras e por um significado idêntico. O segundo volume, que apareceu por último, contém principalmente índices para os dados dos volumes 3 e 4, e inclui uma série de declarações a respeito das correspondências 
sonoras entre as línguas bantas. Ele contém também conclusões baseadas nas análises estatísticas da difusão de suas séries comparativas, um esboço rudimentar da subclassificação genética das línguas bantas e uma lista de 670 reconstruções lexicais.

1.4 Achille E. Meeussen (1912-1978)

Fundador do Departamento de Linguística do Museu Real da África Central, em Tervuren (Bruxelas), na Bélgica, Meeussen foi também professor de línguas africanas nas universidades de Leuven e Leiden. Seu trabalho comparativo sobre as línguas bantas encontra-se publicado de forma dispersa em artigos breves e concisos. Suas publicações mais abrangentes são Bantu grammatical reconstructions (BGR 1967) e Bantu lexical reconstructions (BLR 1969).

Meeussen iniciou o programa de pesquisa "Lolemi” (*lv =lími 'língua, linguagem'), um empreendimento coletivo que resultou num grande número de publicações de estudos comparativos bantos, muitos deles foram publicados em Tervuren reunidos na série Africana linguistica, que existe até hoje.

Uma das grandes contribuições de Meeussen e que pode traduzir seu pioneirismo foi sua análise da estrutura do verbo banto contida no seu artigo Bantu grammatical reconstructions (1967), justamente publicado na revista Africana linguística, em Tervuren. Esse material serve de fonte de trabalhos até hoje.

Finalmente, para falar dos herdeiros de Meeussen, podemos citar Thilo C. Schadeberg (autor do artigo que inspirou esta parte do nosso trabalho), considerado um dos brilhantes alunos de Meeussen. 


\section{As línguas bantas 6}

\subsection{Localização das línguas bantas}

As línguas bantas são faladas pelas comunidades localizadas numa região delimitada por uma linha imaginária que vai do sul da Nigéria, na sua fronteira com a República do Camarões, atravessa a República Centro-Africana, a República Democrática do Congo (exZaire), Uganda, e Quênia, até o sul da Somália no leste do continente africano. A maioria das línguas faladas entre essa linha e a República da África do Sul é composta por línguas bantas, aproximando um total de 27 países. São eles: Angola, Botsuana, Burundi, Camarões, República Centro-africana, Comoros (ilha), Congo, República Democrática do Congo (RDC), Guiné Equatorial, Gabão (país de origem do autor deste trabalho), Quênia, Lesotho, Madagascar (a grande ilha), Maláwi, Mayote (ilha), Moçambique, Namíbia, Nigéria, Ruanda, Somália, África do Sul, Sudão, Suazilândia, Tanzânia, Uganda, Zâmbia, e Zimbábue.

De um total de cerca de 726 milhões de africanos (TIMES ATLAS, 1999), a mais recente publicação (LEWIS, 2009) relata a existência de cerca de 382 milhões de falantes de línguas da grande família Nigero-Congolesa, dos quais cerca de 240 são falantes de línguas bantas, sendo que de três africanos, um é falante de língua dessa família.

Não há consenso sobre o número total de línguas bantas: Guthrie (1967-71) afirma serem umas 400 variedades de línguas bantas, Lewis (2009) informa que são 501 (menos algumas 'extintas' ou 'quase extintas'); Bastin et alii (1999) calculam 542; Maho (2003) soma aproximadamente 660; e Mann et alii (1987) argumenta sobre cerca de 680. Digamos que o número varia entre 400 e 680 línguas. O problema nesse caso, na verdade, está situado em como saber diferenciar uma língua de um dialeto na África subsaariana, ou seja, a questão está em delimitar língua e dialeto.

A esse respeito, a área da sociolinguística oferece uma resposta convencional, segundo a qual (i) a língua tende a ser uma variedade padrão, que é escrita, (ii) apresenta um número maior de falantes, (iii) goza de um estatuto oficial, detendo maior prestígio, e (iv) não é inteligível a falantes de outras 'línguas'. Com particularidades diametralmente opostas, os dialetos (i) são as variedades não-padronizadas, (ii) não são escritos, (iii) apresentam um número restrito de falantes, (iv) gozam de um estatuto não-oficial, daí deter pouco ou nenhum prestígio, e (v) são mutuamente inteligíveis a falantes de outros dialetos.

\footnotetext{
${ }^{6}$ Este trabalho é inspirado do artigo 'Historical Linguistics' de T. Schadeberg publicado em Nurse e Philippson (2003) e também da obra de Nurse (2008).
} 
Na África subsaariana, esses critérios são apenas parcialmente aplicáveis. Em alguns casos, a distinção entre língua e dialeto pode ser feita por critérios em parte linguísticos e, em parte, políticos, o que implica de uma parte e de outra, graus de prestígio. Portanto, não se têm claramente definidos os limites entre os estatutos de língua e de dialeto quando se avalia a complexa realidade da África subsaariana.

Um índice do quão diferente são as realidades linguísticas pode ser depreendido pela inexistência de uma palavra para rotular 'dialeto'. A palavra 'língua' cobre toda a extensão de significações que abarcam em outras realidades sentidos mais restritos, e não menos complexos, como o de dialeto. No caso do lembaama falado no Gabão (na província do HautOgooué), por exemplo, a língua é o lembaama que engloba dois falares mais conhecidos: lempiini (lê = prefixo da classe 9 que significa língua, mpiini $=$ floresta. Ou seja, lempiini $=$ falar da floresta) e lembéré (mbéré = parte baixa. Ou seja, lembéré = falar da parte baixa). Ocorre que ambos são inteligíveis para as duas comunidades.

Cientificamente, falaríamos de dois dialetos da mesma língua: o lembaama, já que há intercompreensão, contudo das duas variantes a que foi descrita e escrita primeiro pelos missionários foi lembéré, chamada de mbede pelos estudiosos ${ }^{7}$. O efeito disso é que ao lembéré foi conferido um certo reconhecimento científico, e essa é a razão por que na classificação de Lewis (2009), lembaama (B62) é um subgrupo do mbede (B60). Lempiini sequer aparece nessa classificação, razão por que uma inversão indevida de estatuto embutese aí: por ser a língua, lembaama viria antes.

\subsection{Classificação genética das línguas bantas}

Todas as línguas bantas, também chamadas de bantoides, fazem parte do grupo Benuê-Congo e do tronco Nigero-congolês (Cf. classificação genética em anexo ${ }^{8}$ ). O Nigerocongolês é o maior grupo genético do mundo: cerca de 1.489 'línguas' são vinculadas a esse grupo.

As línguas bantas são convencionalmente divididas em dezesseis zonas (A, B, C, D, E, F, G, H, J, K, L, M, N, P, R, S), que por sua vez são divididas em número de dezenas. Essas são aproximadamente em torno de oitenta. Assim temos A10, A20, B10, B60, etc. Cada uma se refere a um grupo de línguas. É o caso da zona A que tem as línguas A11, A12, A13, etc.

\footnotetext{
${ }^{7}$ Uma das razões atribuídas para o fato é que essa é a variante mais fácil de escrever.

${ }^{8}$ Essa classificação genética é tirada de Williamson e Blench (2000).
} 
Cada uma se refere a uma língua específica dentro de A10. Esse sistema é baseado na classificação de Guthrie (1967-71), atualizada por Maho (2003).

Segundo estudiosos, as línguas bantas do Leste e do Sul da África são em geral mais conservadoras do que as do noroeste. Isso porque as línguas do noroeste formam a parte leste de uma área geográfica e tipológica que abraça línguas adjacentes do oeste da África incluindo muitas línguas não bantas.

É difícil definir uma linha entre uma língua banta e uma língua não banta dentro da grande família Nigero-congolesa. Isso ocorre porque as línguas bantas do noroeste demonstram características 'não-bantas' enquanto seus parentes e vizinhos demonstram características bantas. Segunda os autores acima citados, esse problema tem dúvidas tipológicas (cf. GUTHRIE, 1948, p. 11-12) e históricas (cf. BENNETT; STERK, 1977; WILLIAMSON, 1989; WILLIAMSON; BLENCH, 2000).

Algumas características são comuns às línguas bantas, como:

1) Duas negações contrastivas: uma na posição pré-inicial associada à proposição principal ou independente, e outra na posição pós-inicial associada com dependentes ou pequenas estruturas, como os relativos, os subjuntivos e infinitivos (Kamba Muzenga, 1981, Güldemann, 1999a);

2) O aspecto em certos verbos é expresso por finais específicos ( -ile, -i, -a(n)ga);

3) Dois padrões de formação do locativo, o uso das classes 16-18 versus o uso de preposições; entretanto, classes locativas também ocorrem em algumas línguas não-bantas (as línguas Beboid, por exemplo);

4) As línguas bantas apresentam muitos graus para se referir ao passado e ao futuro (Cf. cap.6 de Nurse, 2003; Nurse 2008);

5) As línguas bantas apresentam uma harmonia nasal. Temos uma imagem clara embora não totalmente completa da sua distribuição nas línguas bantas (Greenberg, 1951), mas ainda não temos certeza do seu desenvolvimento inicial no período pré-banto;

Os autores Nurse e Philippson (2003) alertam que é preciso conhecer melhor a respeito da distribuição dessas características na grande família Nígero-congolesa e fora dela para termos certeza que são traços peculiares das línguas bantas. 
2.3 Características tipológicas das línguas bantas

Três pontos merecem ser esclarecidos quando se trata de classificar tipologicamente as línguas bantas:

1. Os fatos apresentados para a caracterização tipológica mudou desde o início da classificação e continuam mudando (Johnston, 1919-22, Guthrie 1948, Greenberg 1963a, 1966, 1978b, Meeussen, 1967, Heine 1976, Heine e Vossen 1981, Comrie, 1989, Nichols, 1992);

2. na tentativa de definir o banto historicamente, deparamo-nos com a dificuldade de distinguir especificamente o que é só do banto dentro da grande família Nigero-congolesa;

3. as línguas bantas do noroeste da África, às quais pertence o lembaama, são muitas vezes exceções para as generalizações sobre as línguas bantas, isso porque elas não inovaram ou perderam algumas características.

Apresentamos, resumidamente, alguns traços característicos das línguas bantas ${ }^{9}$

a) Vogais: o protobanto possuía 7 vogais opostas, e a maioria das línguas bantas de hoje apresentam 7 ou 5 vogais (poucas dentre elas têm mais de 7 vogais, poucas também têm vogais nasalizadas). O protobanto tinha vogais que se opunham pela duração (vogais breves versus longas), mas que não parecem distinguir muitos pares mínimos lexicais. Algumas línguas bantas atuais mantêm essa distinção: é o caso do lembaama; outras neutralizaram-na. Há duração sincrônica de vogais e que aparece em contextos típicos (depois de glides, antes de uma consoante e de uma nasal moraica na penúltima posição). Certos processos fonológicos que afetam vogais são bem recorrentes: uma harmonia na altura vocálica (especialmente nos radicais das extensões verbais) e a semivocalização ou ainda a labialização e palatalização das vogais $u / o$ e i/e para $w$ (labialização de u) e $y$ (palatalização de i), respectivamente diante de vogais não-identificadas.

b) Consoantes: o sistema de consoantes do protobanto era relativamente simples. Havia 4 (ou 3 , a depender de como são interpretados os sons $* c$ e $* j$ j) posições de articulação e distinção de voz (vozeamento distintivo). Entretanto há uma série de oclusivas não-vozeadas, não se sabe claramente se seus pares vozeados eram consoantes longas ou oclusivas também. O protobanto tinha características extraordinárias como grupos de nasais e oclusivas

\footnotetext{
${ }^{9}$ O estudo de Nurse (2003) é a referência de todos os itens aqui tratados.
} 
homorgânicas (*mp, $m b, n t, n d$, etc.) e uma falta geral de fricativas. Algumas línguas, principalmente aquelas com as 7 vogais originais mantêm exatamente esse sistema consonantal, enquanto outras, aquelas que sofreram processos de espirantização e de africação (fato de uma consoante se tornar africada) antes de duas vogais altas e a redução de 7 para 5 vogais tem expandido o sistema e desenvolvido fricativas. Processos como aspiração, lenição em geral, palatalização, espirantização, vozeamento pós-nasal e a harmonia nasal (Greenberg, 1951) são bem difundidos.

c) As sílabas: são todas abertas $((\mathrm{N}) \mathrm{CV}, \mathrm{NV}, \mathrm{V})$ na maioria das línguas bantas.

d) Os tons: cerca de $97 \%$ das línguas bantas são tonais. O quissuaíli e o comorense são as raras línguas bantas sem tom. Os tons afetam a sílaba, ou seja, uma palavra ou parte de uma palavra composta por consoante(s) e vogal (ou vogais). Todas as línguas bantas que têm tom distinguem duas alturas tonais: alto e baixo (A, B), analisados como /A/ vs $\varnothing$ (sem tom)(NURSE; PHILIPPSON, 2003, p. 8). Os processos tonais mais espalhados são: o downstep; o espraiamento, a mudança que costuma acontecer da esquerda para direita; a desfavorável ou mal vista sucessão de tons altos chamada Príncipio de Contorno Obrigatório (Obrigatory Contour Principle - OCP).

A tonologia nominal é relativamente simples. Radicais dissilábicos podem, em princípio, ser $\mathrm{AA}, \mathrm{AB}, \mathrm{BA}$ ou $\mathrm{BB}$. Os prefixos nominais são, em geral, baixos, os préprefixos chamados 'aumentos' são altos e os sufixos derivacionais também têm tons distintivos.

A tonologia verbal é mais complicada principalmente porque o verbo é uma palavra mais complicada comparada ao nome: o verbo varia de acordo com o tempo, o aspecto e o modo (TAM) enquanto o nome em banto só varia em termos de número. Muitas línguas têm um tom lexical associado com o radical verbal e muitos morfemas gramaticais carregam um tom. Assim, por exemplo, a primeira e a segunda pessoa que marcavam o objeto costumavam ter tom baixo no protobanto (e continuam assim até hoje em muitas línguas), como eram os marcadores de sujeitos que representavam pessoas no singular, hoje, todos os marcadores de objetos e sujeito têm tom alto. Além disso, pode também haver tons gramaticais em algumas línguas: um tom alto é atribuído a uma mora particular no radical ou no verbo, dependendo da categoria gramatical (TAM). Para línguas que contam moras, há sempre uma elevação do tom sobre uma mora culminante. Alguns morfemas gramaticais não têm tom nenhum, por 
exemplo, nas extensões. O tom em geral delimita constituintes sintáticos e verbos que são seguidos de preposições (verbos que têm pós-posições). Para ilustrar o tom gramatical nas línguas bantas, vejamos os seguintes exemplos:

Em yambasa (A62) (Yukawa, 1992), por exemplo, o passado é marcado por um tom alto que vai da segunda até as silabas finais. Assim, temos:

(1a) gu\#dóneno 'chamar'

(1b) gu\#nyongolonyo 'fazer cócegas (em)'

Esses dois verbos têm como passado remoto, respectivamente:

(1c) amba\#dónénó 'ele chamou' e

(1d) amba\#nyongólónyó ‘ele fez cócera (em)’.

O mesmo padrão é encontrado em kamba (E55):

(2a) nétwáa\#konéthésŷิ 'nós fizemos bater'(/kon/)

(2b) nétwáa\#táléthésyĉ 'nós fazemos contar' (/tal/).

(NURSE; PHILIPPSON, 2003, p. 61-2).

\section{e) A morfologia}

As línguas bantas têm uma morfologia aglutinante. Os verbos têm uma série elaborada de afixos (cf. Capítulo III desta tese). A maioria das línguas bantas tem nomes derivados e não-derivados: os nomes derivados têm um prefixo flexionado e um sufixo derivacional. Para verbos e nomes, a análise convencional começa com um radical ou uma raiz que mais freqüentemente tem a forma -(i)CV(C)- (NURSE; PHILIPPSON, 2003, p. 8). Para nomes, um radical é formado pela incorporação de um sufixo derivacional (geralmente composto apenas de uma vogal). Para verbos, uma base pode ser derivada da raiz, pela sufixação de uma extensão e pela incorporação de um sufixo flexional na final verbal, o que gera um radical ao qual uma flexão do pré-radical é acrescentada. A série de sufixos é limitada para nomes e verbos. Para nomes um prefixo de classe é acrescentado, e em algumas línguas existe um préprefixo chamado de aumento. Todos os nomes têm uma classe. São ao todo mais de vinte classes nominais reconstruídas para o protobanto (PB), embora as línguas bantas de hoje na sua maioria tenham entre 12 e 20 classes nominais, algumas línguas bantas reduziram e até eliminaram suas classes nominais (cf. os capítulos 15, 16 e 23 de NURSE; PHILIPPSON, 2003). 
Uma classe é caracterizada por um prefixo distinto, um emparelhamento (singular/plural) específico (e característico) chamado de 'gênero' pelos bantuístas e uma concordância com os outros constituintes. Durante quase todo o século XX, na semântica, observou-se uma arbitrariedade na delimitação das classes nominais, mas nos últimos anos observa-se uma tentativa de encontrar generalizações nesse sentido.

As línguas bantas têm sido descritas como 'verby' (em que o verbo é fundamental na construção do sentido da oração). O verbo é o elemento central da oração: incorpora muitas informações e pode ficar sozinho como uma sentença. Quase todas as línguas bantas são prodrop (o verbo nem sempre precisa da presença do sujeito, mas necessita da presença de um índice do sujeito. No capítulo III explicaremos o que é o índice do sujeito). Em várias línguas bantas, os verbos têm seis posições possíveis no pré-radical. A partir daí, algumas podem ser preenchidas por mais de um morfema; é frequentemente possível ter uma dezena de morfemas ou mais num verbo. Um exemplo extremo é dado sem glosa na língua kinande (DJ42) por Philip Mutaka (NURSE; PHILIPPSON, 2003, p. 9):

(3) tu-né-mu-ndi-syá-tá-sya-ya-ba $\neq$ king-ul-ir-an-is-i-á $=k y \hat{o}^{10}$ (Nós possibilitaremos isso mais uma vez para que eles abram isso para cada um deles).

Entre eles, os prefixos e sufixos verbais expressam geralmente a negação, a relativização (o relativo), o tempo, o aspecto, o condicional (a condição), o sujeito (a pessoa/ classe nominal), o objeto (a pessoa/classe nominal), o foco/ a asserção, as extensões derivacionais, o modo, e os elos entre aspectos do discurso e da sintaxe. Outras categorias podem também ser consideradas, especialmente nas posições inicial e final do verbo. Muitas línguas bantas têm duas marcas de negação. Uma que ocorre nas orações principais, a outra ocorre nas estruturas menores ou dependentes. Muitas línguas bantas se caracterizam por uma rica série de contrastes entre tempos verbais e entre aspectos verbais também. Muitas também têm verbos compostos em que um verbo principal flexionado (conjugado) pode ser precedido por um ou mais verbos auxiliares também flexionados (conjugados).

A concordância se reflete a partir do nome-núcleo através do grupo nominal até no verbo. Em algumas classes o prefixo do acordo é o mesmo para todos os constituintes da oração. Em outras, há um tipo de prefixo para nomes e adjetivos, um outro para possessivos, demonstrativos, conectivos, marcadores do sujeito do verbo e frequentemente para

\footnotetext{
${ }^{10} \mathrm{O}$ exemplo está sem glosa no original.
} 
marcadores de objetos e outras categorias menores. Em outras ainda, nomes e adjetivos são marcados diferentemente.

Nos demonstrativos, muitas línguas bantas opõem três tipos de demonstrativos: perto do falante, perto do interlocutor e longe dos dois interlocutores. É o caso na língua lembaama que diferencia respectivamente, por exemplo: akáásí ba (estas mulheres), akáássí báá (essas mulheres), akáássí báníiní (aquelas mulheres ali).

\section{f) A sintaxe}

A ordem não-marcada (default) dos constituintes de uma oração completa na maioria das línguas bantas é S (Aux) VO (adjuntos). Uma pequena parte de línguas bantas tem a seguinte ordem predominante: OV. É o caso da língua nen ou banen ou tunen (A44) (cf. capítulo 16 de NURSE; PHILIPPSON, 2003). Poucas têm a seguinte ordem: V+Aux. É o caso das línguas langi ou irangi (F33) e mbugwe ou buwe (F34). Por razões pragmáticas, o objeto pode ser anteposto e o sujeito posposto. Dessa maneira, o foco pode ser marcado pela ordem das palavras ou por morfemas intraverbais. Uma informação codificada na sintaxe pode ser codificada na morfologia. Zero, um, dois ou três argumentos podem ser codificados intraverbalmente, dependendo da língua. O terceiro argumento será codificado pela extensão do verbo ou alternativamente por um locativo adjunto. A ordem dos morfemas intravebais reflete a dos argumentos externos que, por sua vez, seguem uma determinada hierarquia. Como se espera de todas as línguas que tenham a ordem sintática VO e em geral, o nome precede seus modificativos dentro do grupo nominal. A ordem comum é $\mathrm{N}+\mathrm{Adj}+\mathrm{Numeral}$ + outros constituintes, mas considerações pragmáticas dominam muito a flexibilidade. A maioria das línguas bantas tem poucas preposições verdadeiras ou adjetivos. As línguas bantas não têm artigos. Então, definem pessoas, objetos, etc., via aumento nominal (sujeito), marcador do objeto no verbo (objeto) ou pela ordem do demonstrativo no grupo nominal.

Segundo Nurse e Philippson (2003, p. 9), Thomas Bearth (em comunicação pessoal) afirma que a estrutura sintática básica das línguas bantas não oferece nada muito particular. Nem sua ordem de palavras, já que SVO é a ordem mais comum nas línguas do mundo. Nem o sistema de concordância baseado na classificação nominal é inusitado. Mesmo a dupla representação dos constituintes núcleos pela incorporação de elementos pronominais no verbo para a redução das estruturas e para ajustar/especificar o verbo, não é única ao grupo banto ou à família nigero-congolesa. Os autores concluem que é a combinação de todas essas 
características com o dinamismo das propriedades da estrutura sentencial das línguas bantas que faz a originalidade da sintaxe dessas línguas.

\section{Características tipológicas das línguas bantas da floresta ${ }^{11}$}

Antes de tudo, é preciso levar em conta que a floresta é o lugar da heterogeneidade linguística por excelência: é um lugar de contatos e fronteiras entre línguas. Embora seja possível imaginar que os povos da floresta tenham um modo de vida análogo, o estudo linguístico revela que a floresta é um lugar de difícil acesso, onde a comunicação é essencialmente estabelecida por vias navegáveis e onde a ausência de um contato regular ajuda a manter as fronteiras existentes entre os diferentes grupos linguísticos. Assim sendo, a floresta equatorial é o lugar onde as línguas bantas fazem fronteira com as línguas ubanguianas no oeste da África e com as línguas sudânicas do leste do continente africano. É também o lugar onde encontramos as linhas divisórias que a classificação linguística mostra entre, de um lado, as línguas bantas do bloco do leste e o do oeste; e do outro lado, as línguas bantas do noroeste (zona A + B10, B20, B30) e o restante das línguas ocidentais. Todos os tipos de fronteiras podem ser encontrados nessa área geográfica: fronteiras entre diferentes famílias genéticas, fronteiras entre diferentes grupos da mesma família e fronteiras entre os maiores grupos que são separados dentro do próprio grupo banto (GRÉGOIRE, 2003, p. 349). A autora afirma que a delicada questão que representa a presença dos povos pigmeus na floresta da África central deve ser considerada no estudo das línguas bantas dessa região.

Notamos que, a despeito das valiosas contribuições de vários autores, ainda há muitas lacunas na documentação sobre as línguas bantas da floresta. Há línguas com poucas descrições e outras sem descrição alguma. Essa percepção de lacunas propiciaria uma explanação exaustiva do tema, no entanto, apresentamos uma breve síntese de peculiaridades fonológicas e morfológicas dessas línguas, sem, contudo, ter qualquer pretensão de esgotá-las.

\footnotetext{
11 Este trabalho é uma síntese do capítulo 'The bantu languages of the forest' da Claire Grégoire (2003: 349370) publicado em Nurse e Philippson (2003). Nesta síntese procuramos estabelecer um diálogo entre lembaama (que é o objeto do nosso estudo) e as outras línguas da floresta estudadas por Grégoire. Damos exemplos descritos em lembaama para ilustrar os nossos pontos de vista na descrição dessa língua. O mapa das línguas bantas da floresta apresentado pela autora está no anexo deste trabalho.
} 
3.1 Características gerais fonológicas das línguas bantas da floresta

\section{a) As vogais}

A maioria das línguas bantas da floresta apresenta um sistema vocálico de 7 oposições vocálicas [i e $\varepsilon$ a $\supset$ o u ]. Essa seria a maior propriedade que essas línguas têm em comum. É como se elas tivessem sido poupadas da inovação que reduziu esse número para 5 vogais [i e a o u] que encontramos hoje na maioria das línguas bantas.

A maioria dessas línguas apresenta vogais nasais fonéticas, mas que tendem a se tornar fonológicas. Este não é o caso do lembaama, cujas vogais são nasalizadas por consoantes prénasalizadas. A extrema tolerância demonstrada por essas línguas com relação à sequência de vogais coincide frequentemente com uma aplicação um tanto não sistemática da elisão vocálica ou da semivocalização derivada do contato entre morfemas. Em algumas dessas línguas, a sequência de vogais pode igualmente aparecer por causa da elisão de certas consoantes colocadas em certos ambientes. Essa elisão pode ser obrigatória ou opcional, ou pode ser relacionada à velocidade da fala. Exceto nos grupos B10, B60 (grupo a que o lembaama (B62) pertence) e B70, as línguas bantas da floresta geralmente exibem uma sequência de vogais dentro de uma raiz nominal assim como no contato entre morfemas, especialmente entre prefixos e raízes, dentro de um verbo derivado ou numa sequência de morfemas antepostos ao radical.

Muitas línguas apresentam sequências de 3 vogais. Por exemplo ${ }^{12}$ :

\begin{tabular}{|c|c|c|}
\hline \multirow[t]{2}{*}{ (4a) $a k a(\mathrm{C} 10)$} & mogúía & 'profundidade' \\
\hline & ngùìá & 'javali' \\
\hline \multirow[t]{2}{*}{ (4b) lombo (C54) } & lìóì & 'fala' \\
\hline & bàúuè & 'choros' \\
\hline \multirow[t]{2}{*}{ (4c) mongo (C61) } & lòúá & 'água encima das plantas’ \\
\hline & 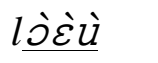 & ‘lábio’ \\
\hline
\end{tabular}

A duração vocálica é fonológica nas línguas bantas da floresta dos grupos B60 (grupo de que faz parte o lembaama (B62)), B70 e B80; assim como nessas línguas: bobangui (C32), ngombe (C41), boa (C44), tofoke (C53), tetela (C71), lengola (D12), enya (D14) e bali (D21). Ainda é difícil estabelecer um mapa geográfico dessa característica. Segundo Grégoire (2003:352), embora muitos autores reconheçam essa característica nas línguas, pares mínimos

\footnotetext{
${ }^{12}$ Exemplos extraidos de Grégoire (2003, p. 352).
} 
opondo vogais breves a longas são raros. Entretanto, com a língua lembaama, observamos o contrário, há vogais breves e longas fonológicas (OKOUDOWA, 2005, p. 11).

\section{b) As consoantes}

O sistema consonantal das línguas bantas da floresta é repleto de particularidades. Só destacamos algumas características mais importantes. São elas:

(i) o grande número de consoantes labiovelares do tipo $k p, g b, \eta \mathrm{kp}, \eta g b$ ou das implosivas como 6, đ (que não encontramos no lembaama) é mais frequente nessa área do que em outras áreas das línguas bantas. Uma influência das línguas vizinhas (não-bantas) poderia explicar esse fato, entretanto ainda faltam provas nesse sentido;

(ii) uma característica particular dessas línguas é a ausência da consoante lábio-nasal nas formas prefixadas. Esse fenômeno denuncia sua natureza tanto fonológica quanto morfológica, porque a consoante $/ \mathrm{m} /$, nas outras línguas, corresponde à consoante $/ \mathrm{b} /$ nos prefixos do tipo $\mathrm{CV}$-, mas corresponde a $/ \mathrm{m} / \mathrm{em}$ outro lugar. Isso pode ser observado na área que cobre as línguas do grupo C60 chamadas de grupo-Mongo que se estende até as línguas ngando (C63), yela-kela (C74-75), ombo (C76) e ndegese (C81) dentre outras;

(iii) muitas línguas da zona $\mathrm{C}$ demonstram uma tendência marcada de elidir certas consoantes numa fala rápida, pelo menos em alguns contextos específicos. As mais vulneráveis são $/ b / \mathrm{e}$ $/ l$, mas em muitas outras línguas, essa tendência pode ser aplicada às consoantes como $/ m$, $t$, $k, z$. Essas elisões opcionais só podem ser observadas nas consoantes em posição intervocálica dentro de uma oração ou num conjunto de palavras que não contêm verbo, numa expressão ou numa locução e essencialmente para consoantes que são prefixos. Entretanto, nunca ocorre elisão quando a consoante está no início de uma oração;

(iv) a sequência de uma nasal e de uma consoante oral que pode ser encontrada nas línguas bantas da floresta exibe algumas características interessantes, tanto pela sua natureza, como pela sua distribuição geográfica: - a primeira que merece alguma discussão é a presença ou a ausência da sequência de uma nasal e de uma consoante desvozeada. Essas consoantes são ausentes em muitas línguas da zona B (pove B22c, kota $\mathrm{B} 25$, tsogo $\mathrm{B} 31$, pinji $\mathrm{B} 30$, nzebi $\mathrm{B} 52$, fumu $\mathrm{B} 77 \mathrm{~b}$, etc.), da zona C (koyo $\mathrm{C} 24$, mboshi $\mathrm{C} 25$, aka $\mathrm{C} 10$ ), e nas línguas localizadas ao norte e vizinhas do grupo ngiri (C30), línguas do grupo C50, e também em algumas línguas da zona D (lengola D12, mituku D13, bira D32, nyali D33, bodo D35, etc.). A maioria delas é 
falada ao norte da floresta equatorial. Em lembaama essa sequência é presente e aparece muito no início e no meio de várias palavras (OKOUDOWA, 2005, p. 20);

(iv) em algumas línguas localizadas no sul, a sequência NC pode sofrer outros tipos de reduções. Numa pequena área onde existem línguas como tetela $\mathrm{C} 71$, kela $\mathrm{C} 75$, ombo $\mathrm{C} 76$, e mituku D13, segundo a regra de Meinhof, nota-se a redução de sucessões de nasais e consoantes orais em uma nasal homorgânica (que é às vezes longa) se o ataque da sílaba seguinte for uma nasal ou uma sequência de $\mathrm{N}+\mathrm{C}$ vozeada. O mesmo fenômeno se aplica também às representações como $m b$ - e $n d$ - de um prefixo do tipo (-)N- que aparece antes de raízes iniciadas por vogal. Assim, encontramos os seguintes exemplos na língua kela (C75): நòndé 'crocodilo', நj̀mò 'tambor', lìsóngànà 'casar-se'. Na língua mituku (D13), temos: òlàngà, pl. màngà 'lança'; kònàmbà 'criticar-me', mas kòndźtà 'chamar-me' com objeto na primeira pessoa do singular cujo prefixo é $n d$ - que vem antecedendo o radical do verbo iniciado por uma vogal; mas seria $n$ se o radical do verbo fosse do tipo + VNC-. Em ombo (C76), temos: Iòángá, pl. mmángá 'queixo'; ménà 'ver'(radical do verbo: + Én-) mas mbìyà 'chegar' (radical do verbo: $+\hat{i} y$-).

Há línguas como nkengo e ngando (C60) que reduzem sistematicamente a sequência $\mathrm{N}+$ consoante vozeada em uma nasal homorgânica em todos os contextos, no início e no interior da palavra. Dessa forma, em ngando temos: múlà 'chuva', mwá 'cachorro'. Isso é de fato contrário ao que temos em lembaama (B62), em que é possível se encontrar: mvlá 'chuva', mvá 'cachorro'.

Nenhum dos fatos assinalados até aqui, no entanto, é exclusivo das línguas bantas da floresta. É justamente por isso que, somente um estudo mais completo e pormenorizado desses processos ajudaria a entender melhor até mesmo fenômenos similares que podem ser observados nas demais línguas bantas do noroeste, ou até em certas línguas bantas do sul.

\section{c) Os tons}

Sistemas tonais das línguas bantas da floresta (doravante LBF) não demonstram nenhuma uniformidade, por outro lado, a falta de descrições do tom nessas línguas não permite saber muita coisa sobre esse fenômeno linguístico supra-segmental. 
Algumas línguas da zona D, como lega (D25), têm dois tons e um downstep ${ }^{13}$ dos tons altos; muitas línguas do sul e da zona $\mathrm{C}$ têm tons alto e baixo e tons modulados que manifestam uma grande estabilidade, sendo dificilmente modificados dentro da oração, se excluirmos as regras que se aplicam ao contato entre morfemas e palavras. Entretanto, esses contatos têm um impacto importante sobre a tonalidade devido ao grande número de elisões de vogais e de consoantes (opcional ou obrigatório) já mencionadas nos parágrafos precedentes.

A maioria dos tons são frequentemente combinados e podem formar modulações tonais como $\mathrm{AB}$ (alto e baixo) ou $\mathrm{BAB}$, que são excessivamente abundantes nessas línguas. $\mathrm{A}$ língua tetela $(\mathrm{C} 71)$ tem um processo de espraiamento do tom alto, que é bastante frequente na família banta como um todo, mas que parece ser raro nessa parte do grupo $\mathrm{C}$, embora exista igualmente em algumas línguas do grupo ngiri C30.

Talvez seja por causa da influência das línguas sudânicas do centro, de um lado, e das línguas ubanguianas, do outro, que algumas línguas do norte da zona D e C têm 3 tons: alto, médio e baixo.

O sistema tonal mais complexo se encontra em duas principais áreas: a área ocupada pelas línguas do grupo ngiri (C30) e a área ocupada pelas línguas do grupo B. Grégoire (2003: 357) afirma que os tons do grupo ngiri são de dois tipos, embora ainda não se tenha estudado profundamente o sistema tonal desse grupo. Línguas localizadas ao norte nas margens do grande rio Congo (mabale, poto, motembo, doko) ou entre o grupo ngiri e ubangui (zamba, lobala, bomboma, lingonda, ebuku) têm um sistema tonal muito complexo. Segundo Twilingiyimana (1984) e Kamanda (1991), doko e zamba têm downstep. Além disso, as modulações tonais das formas nominais são altamente dependentes da influência dos tons altos iniciais, que estão presentes devido à persistência do aumento (um tipo de préprefixo nominal). Em bomboma, formas nominais apresentam modificações tonais que dependem da sua função na oração. Isso acontece também em muitas línguas da zona B e do tipo Congo.

Línguas da zona B que ocupam a parte oeste da floresta costumam ter um sistema tonal complexo também, mas essas línguas são bem conhecidas hoje em dia. Esses sistemas podem ter 'casos tonais ${ }^{14}$, assim como os das línguas do grupo Congo. Isso se pode ver nos

\footnotetext{
13 Abaixamento do tom alto, resultante de um processo de gramaticalização do downdrift, abaixamento tonal previsível, em razão da presença da sequência Alto - Baixo - Alto.

${ }^{14}$ Uma das características mais notáveis das línguas bantas do grupo B é provavelmente a desorientadora variedade das modulações tonais que um dado nome pode assumir em diferentes posições sintáticas. Por
} 
trabalhos de Blanchon (1987b) sobre as línguas do grupo B50 e nos trabalhos de MarchalNasse (1989) sobre a língua nzebi (B52) que é uma língua falada no Gabão e vizinha do lembaama (B62). Ainda não verificamos a existência do fenômeno de 'casos tonais' em lembaama.

O grupo B30 não pertence a esse tipo, mas o sistema tonal dos seus nomes pode ter sido influenciado pelos mais ou menos resíduos do aumento ${ }^{15}$, é o caso em himba e tsogo (B31) que exibem um mecanismo de mudança de tom alto bastante frequente nas línguas bantas. A situação é mais complexa para as línguas do grupo B10, onde a oposição definido vs indefinido é expressa por meio de tons nas formas nominais que são bastante raras e que determinam realizações que parecem não ter recebido ainda nenhuma explicação abrangente ${ }^{16}$.

Outros pontos interessantes que merecem a nossa atenção sobre os tons das línguas bantas da floresta são:

(i) a manifestação da metatonia em línguas bantas da floresta, assim como em várias outras línguas bantas. Segundo Schadeberg (1995:111), metatonia ${ }^{17}$ é o termo reservado para aqueles casos em que o tom do sufixo flexionado de certas formas verbais é alto diante de um objeto, e baixo em outra situação. O autor afirma que é assim que Meeussen (1967:111) reconstruiu o tom do sufixo do infinitivo $-a$, e explica a origem da metatonia na zona A, pelo desaparecimento da parte segmental do aumento: desaparecendo, o aumento deixou seu tom alto que foi incorporado pelo nome. A metatonia, então, poderia ser a incorporação desse tom alto flutuante pelo verbo que o precede. Por exemplo, em $k p \bar{a} ?$ (A53), língua falada na

exemplo, oito variações tonais são encontradas na palavra 'vassoura', em ichira[rìsìrè ], língua do grupo B40 falada no sul do Gabão. As oito formas para 'vassoura' são:

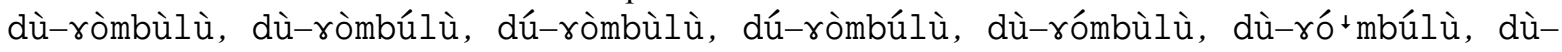
rómbùlù e dú-ró +mbúlù.

Como há frequentemente correlação com a função gramatical, tais formas são às vezes chamadas de 'casos tonais'. Principalmente quando temos, por exemplo:

(1) dùròmbùlù dútsàbénzìrò 'A vassoura quebrou'

(2) nż̀lâbò dùrómbùlù 'Vi a vassoura'

(3) nzə̀lâbə̀ rìràngìlílù dúròmbùlù 'Vi o cabo da vassoura' (Blanchon,1999:37-82).

${ }^{15} \mathrm{Na}$ maioria das línguas bantas o prefixo de classe pode ser precedido por um outro prefixo que é chamado de 'aumento'. Pode ser um pré-prefixo ou uma vogal inicial. Isso porque se trata geralmente de uma vogal somente. $\mathrm{O}$ aumento não se encontra em todas as línguas bantas.

${ }^{16}$ Os trabalhos de Philippson e Puech (Disponível em: <http://www.ddl.ish-lyon.cnrs.fr/Publication/index.html> Acesso em 25 de maio de 2010) representam uma boa tentativa.

17 'Metatony is the term used for those cases where the tone of the final (inflectional) suffix of certain verbs forms is (underlyingly) high before an object and low otherwise' (Schadeberg, 1995:111). 
república de Camarões, temos a seguinte frase que aplica a regra da metatonia (Guarisma, 2003:322):

\begin{tabular}{|c|c|c|}
\hline ṅ-dém & W-ÉÈ-fáfá & bwáp \\
\hline 3-coração & 3-prog-dar(cont)+IPFV & 9+sangue \\
\hline
\end{tabular}

Essa regra é aplicada, por exemplo, em certos tempos verbais de línguas como mituku (D13) e lega (D25), no infinitivo, em mbole-tooli (C60) (em que temos: òlámbà 'cozinhar, preparar' vs òlámbáyèkà 'cozinhar comida') e no presente afirmativo, em pove (B22c) (em que temos: $m$ Ėkàpùndà 'cavo' vs $m$ Ėkàpùndá èbèmb 'É ‘cavo o buraco') (GRÉGOIRE, 2003, p. 368).

\section{d) As sílabas}

Em geral, as línguas bantas da floresta não apresentam sílabas com consoante no final. Porém, há línguas em que a sílaba é apenas constituída pelo núcleo da sílaba. No grupo mongo (C60), há sílabas com a nasal $/ \mathrm{m} /$ em posição de coda. Ela só é silábica se for núcleo da sílaba, com um tom, no caso de se tratar de uma língua tonal. Se a nasal $/ \mathrm{m} /$ estiver na coda não será silábica; isso só ocorrerá se ela for núcleo da sílaba. Essa nasal é muitas vezes um prefixo nominal das classes 9 e 10 e é presente em muitas línguas bantas, inclusive, em lembaama. Nas línguas mongo e ombo (C76) essa nasal é presente em que as línguas adjacentes apresentam sílabas finais como $m i$ e às vezes $m u$.

Seria interessante observar a análise de sílabas com as sequências NC na posição do ataque nas línguas bantas onde elas existem, já que são elas que podem causar problemas de análise fonológica. No lembaama, esse fenômeno não representa mais nenhum problema. Essa sequência é tratada, dependendo do nome, como um segmento único: uma consoante homorgânica ou como dois segmentos: nasal silábica + consoante (que pertence a uma outra sílaba); temos, por exemplo, lèmfú 'cabelo' (pertence à classe 9 e conta duas sílabas: lè.mfú) vs îfú 'cabelos'(pertence à classe 10 e conta também duas sílabas, sendo a nasal silábica com tom baixo: ì.fú) (OKOUDOWA, 2005, p. 32). 
Para terminar, digamos que como nas línguas bantas em geral, a sílaba canônica nas línguas bantas da floresta é também do tipo CV. Finalmente, segundo Grégoire (2003:358), o mais notável dos grupos B30, C10, C50, C60, C70 e D10 é a grande frequência de sílabas que só possuem núcleo.

3.2 Características gerais da morfologia nominal das línguas bantas da floresta

Uma das características comuns das formas nominais das línguas da floresta é que elas não têm uma classe reservada para locativos. Isto é, o lugar não é indicado por meio de um prefixo de classe nominal ${ }^{18}$. Os morfemas locativos são do tipo gó- nas línguas do grupo B, do tipo ò ou ó nas línguas C10 e C30 do grupo ngiri assim como em bolia e ntomba (C35), do tipo ndá ou ǎ nas línguas do grupo C60 e do tipo lá no grupo tetela (C71-3). Ngando(C63) tem a preposição má (por exemplo: malìhòkù 'na valeta'). Um morfema ka é encontrado nas línguas boa (C44), bira (D32) e nyali (D33) onde coexiste com da'a/para', etc.

Todos esses morfemas funcionam como preposições e devem ser analisados como tal. Em lembaama, temos várias preposições para indicar o lugar: ó, nt Sá, ónt Sá, má, jilá 'no(a), dentro de, em, sobre, etc'. Por exemplo:

\footnotetext{
${ }^{18}$ Resumidamente, o sistema de classes nominais é baseado na repartição dos substantivos em prefixos. Esses prefixos nominais por sua vez são repartidos em grupos ou classes sob a base do emparelhamento singular/plural. São uma herança do Protobanto (ancestral comum a todas as línguas bantas). Foram reconstruídas 24 classes nominais. Mas não há nenhuma língua banta que tenha todas elas. Uma das exceções é a língua ganda (JE15) que tem 21 classes nominais. Encontramos 12 em lembaama (Okoudowa, 2005: 32). Os pares mais comuns são:1/2, 3/4, 5/6, 7/8, 9/10,11/10,12/13 e 14/6. O mais uniforme é o primeiro (1/2). Os prefixos de classes nominais são o coração de um sistema de concordância nas línguas bantas. Vejamos os seguintes exemplos (tirados e traduzidos de Katamba, 2003: 111) em quisuaíli, que é uma das raras línguas bantas sem tom:
}

a)

m-toto $\quad \boldsymbol{m}$-dogo a-mefika

1-criança 1-pequeno 1-chegou

'A pequena criança chegou'

b)

$$
\begin{array}{llr}
\text { ki-kapu } & \text { ki-dogo } & \text { ki-mefika } \\
\text { 7-cesta } & \text { 7-pequena } & \text { 7-chegou } \\
\text { 'A pequena cesta chegou' } &
\end{array}
$$

Como se pode observar, nas orações acima, na concordância gramatical, o prefixo nominal é retomado tanto pelo adjetivo, como pelo verbo. 
(6)

báán’álínt Sálekóóli

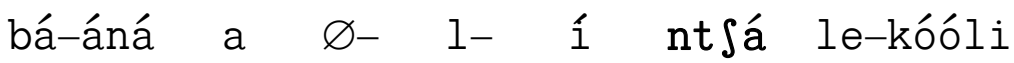

2-crianças IS2 Pres estar VF Prep 9-escola

'As crianças estão dentro da escola'

A classe 12 é rara, mas encontra-se nas línguas do grupo B, como em lembaama, em que ò- é o prefixo de classe. Nela encontramos infinitivos como ò-dzá 'comer', ò-nwá 'beber' e objetos como ò-pélé 'prato'. O mesmo acontece com a classe 15 que se encontra também nas línguas do grupo D. Na zona B, observa-se a fusão das classes 15, 11 e ou 14. O par 13/19 que existe na zona D não se encontra nas línguas dos grupos B60-70 (mbaama-lempiini B62, laale B73, yaa B73c, fumu B77b), etc. (GRÉGOIRE, 2003, p. 359).

Outra característica que merece nossa atenção é a existência de uma classe nominal 1 com prefixo nominal a- numa série de línguas localizadas no nordeste da floresta. Esse é um caso inédito porque geralmente a- é o prefixo nominal da classe 2 , que é o plural da classe 1 . Essa subclasse reúne um pequeno número de nomes que designam animais e plantas e raramente membros da família. Esse prefixo a- tem sido atestado em línguas dos grupos $\mathrm{C}$ e D como buja (C37), doko (C40), boa (C44), lombo-turumbu (C54), kele (C55), mbole-tooli (C60), mituku (D13) e nyali (D33).

Em geral, os prefixos nominais das línguas da floresta são do tipo CV- exceto nas classes 7 e 19, porque sua estrutura vocálica resulta da ausência das consoantes $\mathrm{k}$ e p nos prefixos. Essas classes só têm a estrutura CV- nas línguas da zona D (mituku D13, enya D14, lega $\mathrm{D} 25$, binja D20), em tetela (C71) e numa parte da zona B (tsogo B31, pove B22c, nzebi B52, nduти B63 (língua próxima do lembaama)). Para as outras classes, dependendo da estrutura silábica de cada língua e da classe, há línguas com prefixos dos dois tipos: V- e VC-. Quanto ao lembaama, além desses dois tipos, temos um prefixo zero ( $\varnothing-$ ) nas classes 1,7 e 9 e um prefixo composto por uma nasal silábica como demonstrado acima.

Assim, temos línguas com prefixos do tipo (C)V- diante de uma base nominal que começa por uma consoante; e do tipo $\mathrm{VC}(\mathrm{V})$ - diante de bases nominais que começam por vogais (por exemplo, temos ósálí, pl. básálii 'trabalhador' mas ómáná, pl. ábáná 'criança') na língua Doko (C40). Existem também línguas com estrutura silábica do tipo (C)V-vs $(\mathrm{V}) \mathrm{C}(\mathrm{V})-, \mathrm{C}(\mathrm{V})-$. Nas línguas do centro da floresta como lembaama, o prefixo nominal da 
classe 5 é sempre do tipo CV- (até VCV- ou CVCV-), independente da estrutura silábica da base nominal. Essa última encontra-se em línguas dos grupos B60-70 como nduтu B63 e fumu B77b, na maioria das línguas mais conhecidas dos grupos C10 (aka, ngando e babole), ngiri (C60), bobangi (C32), línguas mongo (C60), etc

Finalmente, Grégoire (2003, p. 362) reconhece que embora pregressos tenham sido feitos nessa área, o conhecimento das línguas bantas isoladas entre línguas ubanguianas e sudânicas ainda é fragmentário. Essa afirmação vale também para as línguas localizadas nas bordas do domínio banto em geral.

\subsubsection{O Infinitivo}

As línguas bantas da floresta apresentam uma situação complexa a respeito daquilo que é tradicionalmente chamado de infinitivo. O que podemos dizer é que, hoje, não há unanimidade sobre a classe nominal usada para formar o infinitivo nas línguas bantas da floresta. Na zona B, por exemplo, temos a classe 5 em tsogo (B31) que tem como prefixo nominal è-; segundo Grégoire (2003, p. 367) em lembaama (B62), há o prefixo 15, afirmação que contestamos, uma vez que, no lembaama, há menos de 15 classes nominais. O que existe na verdade, é um vestígio da classe 15 do protobanto (forma reconstruída e comum a todas as línguas bantas) que serve de prefixo tanto para alguns nomes quanto para o infinitivo, pertencendo, contudo, à classe 12 do lembaama (OKOUDOWA, 2005, p. 32).

$\mathrm{O}$ infinitivo pertence à classe 15 nas línguas como laale (B73b), yaa (B73c) e fumu (B77b), mas está na classe 7 em ndumu (B63) e em algumas línguas do grupo teke (B70), na classe 3 em himba (B30), classe 5 com um prefixo nominal zero em pove (B22c). A situação continua heterogênea até nas línguas das zonas C e D (há uma exceção no sul desta zona onde o infinitivo é da classe 15 e ocorre com um deverbal da classe 5).

$\mathrm{Na}$ zona $\mathrm{C}$, fala-se de um grande número de formas nominais e verbais ao mesmo tempo (chamadas 'nominoverbais' por Grégoire (2003, p. 367)) cujo uso difere de uma para outra. Contudo, a forma clássica do infinitivo é a seguinte: prefixo nominal da classe $15+$ radical + a; - a é utilizado nas línguas do grupo ngiri C30 (lifonga, likata, libobi, loi, balobo), no grupo C50 (kele, tofoke), C60 (nkundo, mbole-tooli) e D10-20 (mituku, enya, lega), C30 (bolia, litoka, ndobo), C60 (nkengo), C70 (kela). Outras formas do infinitivo, bem representadas, são do tipo: prefixo nominal + radical+ -é, -a, -i que podem ser encontradas em leke (C14), nas línguas do grupo ngiri C30 (mbudza, lifonga, likata, mbonji, babale, mtembo, 
litoka, balobo); formas como $\varnothing+$ radical + -a, -á, -e, - $\varepsilon$ são encontradas em aka (C10), no grupo ngiri C30 (libobi, lobala, zamba, mboji, balobo), boa (C44), bodo (D35) e bira (D32) etc.

Ainda sobre os infinitivos, podemos identificar infinitivos negativos nas línguas bantas da floresta. É o caso da língua tofoke (C53) em que encontramos: ngòlèmà 'não cultivar', ngj̀gógà 'não recolher'.

Existem infinitivos que incluem marcas de deslocamento que podemos encontrar nas línguas como bolia (C35) em que temos: ikèlà 'fazer', iyókèlà 'vir e fazer' e itókèlà 'ir e fazer'.

Há também infinitivos terminados em -o em lembaama (B62) (òlwóró ‘sonhar', òwóbó 'falar'). Esses infinitivos com -o, como já foi dito, são raros nas línguas bantas da floresta.

Para concluir, digamos que, infelizmente, as descrições atuais ainda não permitem entender essas formas de uma maneira exata, tampouco permitem vislumbrar a diferença entre esses nomino-verbais e os deverbais. Entretanto, embora não focalize especificamente as línguas bantas da floresta, a descrição do infinitivo tsuana por Creissels (2004) é uma excelente tentativa de esclarecer o problema da natureza híbrida do infinitivo no conjunto das línguas bantas.

3.3 Características gerais da morfologia verbal das línguas bantas da floresta

Como já havíamos tratado das características gerais da morfologia das línguas bantas, nesta parte focalizaremos apenas as características gerais da morfologia verbal das línguas bantas da floresta.

\subsubsection{Verbos e morfemas verbais}

\section{a) Prefixos verbais ou índice do sujeito}

Normalmente a classe do infinitivo dos verbos nas línguas bantas é a classe 15. Essa é uma herança do protobanto. Mas vimos, acima, que muitas línguas bantas não mantiveram as 24 classes nominais dessa protoforma. Tudo vai depender, portanto, do número total de 
classes nominais de cada língua. É por isso que podemos ter infinitivos em diversas classes nas línguas bantas da floresta: temos infinitivos nas classes 15, 5, 9 ou 14. Por exemplo, para lembaama, que totaliza 12 classes nominais, vimos que o infinitivo se encontra na classe 12 . Assim sendo, os prefixos verbais não apresentam nenhuma particularidade nas línguas bantas da floresta. Entretanto, na concordância verbal da classe 1, há um morfema chamado pela autora (GRÉGOIRE, 2003), assim como muitos outros bantuistas, de prefixo verbal. Esse prefixo é geralmente à- (á em tofoke C53 e lega D25), mas ò em enya (D14).

Em lembaama também temos um ó na concordância da classe 1. Entretanto, esse morfema, para nós, não é um prefixo verbal. É o que chamamos de índice do sujeito (IS). Já que ele retoma qualquer sujeito da classe 1.

Prefixo verbal é uma descrição apenas, que não analisa a função sintática. Na verdade, a denominação 'Prefixo verbal' visa a deixar claro que todo verbo deve ser precedido de uma marca do sujeito. De fato, o índice do sujeito precede o verbo, mas se separa dele por uma marca de tempo. Vejamos alguns exemplos com diferentes índices de sujeitos com a mesma marca de tempo (MT):

mwán’ómît sá tóló

mu- áná ó mî- ts- á $\varnothing-$ tóló

1 criança IS1 MT dormir VF 7-

'A criança dormiu' (Faz pouco tempo)

báán’ámîtsá tóló

bá- áná á mî- ts- á $\varnothing-$ tóló

2 criança IS2 MT dormir VF 7- sono

‘As crianças dormiram' (Há pouco tempo)

De fato, nos exemplos acima, podemos ver que o índice do sujeito da primeira classe (IS1) em lembaama é ó, e na segunda classe (IS2) é á. Vemos, também, que a concordância é dirigida pelo sujeito, localizado no início da oração. O seu índice muda de acordo com seu 
número, isto é, o sujeito tem um índice no singular (na classe 1) e outro no plural (na classe 2). Contrariamente ao sujeito e seu índice, a marca de tempo ou o prefixo verbal não muda: o morfema mí- marca sempre o passado recente (P1) em todas as classes, em lembaama. Esta língua exige um sujeito nas suas orações, exceto no imperativo como na maioria das línguas do mundo. Mesmo assim, o seu índice aparece no imperativo plural. Vejamos esses exemplos:

bsílénw'ándzá

bsi lé $\varnothing-$ nw- á á- ndzá

1p IS1p Pres beber VF 8 água

'Nós bebemos água'

\section{lénw’ándzá}

lè $\varnothing-$ nw- á á- ndzá

IS1p MT beber VF 8 água

‘ bebamos água!'

nw' åndzá

nw- á a- ndzá

Beber VF 8 água

' beba água!'

Como podemos ver, no imperativo plural, o índice do sujeito da primeira pessoa do plural está presente, embora o sujeito não apareça. No singular, nem o sujeito, nem o seu índice aparecem (cf. Capítulo V, sobre Tempo, Aspecto e Modo desta tese).

As línguas da floresta têm poucos prefixos verbais. Muitas vezes elas têm nà- na primeira pessoa do singular. Esse prefixo pode ser encontrado em tsogo (B31), aka (C10), ntomba-tumba (C35), doko (C40), mpunza, lifonga, loi, mbonji, litoka, balobo, ndobo (C30 ngiri), beo (C45) e bodo (D35). Há também formas alternativas como nè- ou nì- que podemos encontrar em algumas línguas do grupo ngiri (C30) (likata: nè nà; libobi: ne-, na-, ni-). Nas 
línguas B10, B30 e pove (B22c) o prefixo verbal da primeira pessoa do singular é $m \mathcal{E}$-. No caso do lembaama (B62), esse morfema existe também. Só que para nós, ele é pronome pessoal da primeira pessoa do singular e seu índice do sujeito é e. Vejamos esse exemplo:

$$
\begin{aligned}
& \text { m’éka yá } \\
& \text { mé e } \quad \varnothing-\quad \text { k- } \\
& \text { 1s IS1s Pres ficar VF } \text { yá }
\end{aligned}
$$

'Eu fico aqui'

Essa forma parece aglutinada ao prefixo verbal da primeira classe la- em dumu (B63), onde a autora (GRÉGOIRE, 2003, p. 363) anota $m$ ' $a$ - ou (me) $a$-.

Com relação aos pronomes pessoais, o prefixo verbal da segunda pessoa do singular é $\grave{o}$ - em quase todas as línguas. De fato, em lembaama, o índice do sujeito da terceira pessoa do

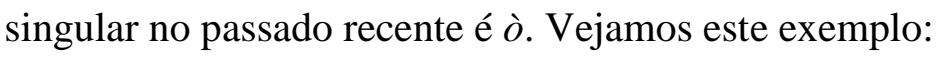

nd 'ómínw' åndzá

ndé o mí- nw- á a- ndzá

3s IS3s P1 beber VF 8 água

'Ele(a) bebeu água' (Há pouco tempo)

Todavia, ndumu e fumu (B77b) usam o pronome substitutivo com o prefixo verbal da classe 1. O fato mais notável é o de que um grande número de línguas tem o mesmo prefixo verbal na segunda pessoa do singular e do plural (exceto quando, por acaso, há uma diferença tonal que não é marcada nas fontes). A estratégia usada por essas línguas para neutralizar a ambiguidade nem sempre é conhecida, mas é interessante saber que algumas delas generalizaram, dentro das formas verbais ambíguas, o uso do morfema (-)ánì, que frequentemente marca o plural do imperativo nas línguas bantas em geral. Exceto em lembaama em que desconhecemos essa marca no imperativo. Mas temos um exemplo na língua mbole-tooli (C60): òsôkambà 'trabalhe (sg)' e òsôkàmbááyì 'trabalhem (pl.)'. Nos casos onde não é idêntico a uma das pessoas do singular, o prefixo verbal é nò- nas línguas tsogo $\mathrm{B} 31$ e pove $\mathrm{B} 22 \mathrm{c}$; bò-, wó- nas em tofoke C53, lombo C54, kele C55, Enya D14, Bira 
D32, ntomba C35 e no grupo ngiri (C30): mpunza, loi, litoka, balobo. Em ndumu (B63), que é uma língua próxima do lembaama, é lì- ou lè-. Em lembaama (B62), é lè- (cf. o exemplo (6) sobre o imperativo plural acima).

Na maioria das línguas bantas da floresta, os prefixos verbais têm um tom baixo nos nomes referentes a pessoas, isto é, na primeira classe, e um tom alto nas outras classes (GRÉGOIRE, 2003, p. 364).

\section{b) Prefixos objetos ou pronomes objetos}

O que a autora chama de 'prefixos objetos' são índices do objeto. Eles retomam o objeto de uma oração. Nesse sentido, praticamente, todas as línguas bantas da floresta têm uma gama de índices do objeto tanto para pessoas como para classes ou pronomes reflexivos. No entanto, observa-se uma ausência dos índices do objeto nas línguas do grupo B10, em pove (B22c), assim como em nduти (B63) е fuти (B77b). Em lembaama, temos uma gama de índices do objeto que acompanham o verbo em função de objeto. Essa gama inclui todos os pronomes pessoais que podem ser tanto sujeitos como objetos. A principal diferença entre eles é que os índices do objeto são pospostos ao verbo, enquanto os índices do sujeito são antepostos ao verbo. Vejamos este exemplo:

$$
\begin{aligned}
& \text { nd 'ómîbíî́lámé } \\
& \text { ndé o mí- bîíl- á mé } \\
& \text { 3s IS3s P1 chamar VF IO1s } \\
& \text { 'Ele(a) me chamou' (Há pouco tempo) }
\end{aligned}
$$

Como podemos observar, o pronome pessoal da terceira pessoal do singular ndé 'ele(a)' que aparece no início da oração, tem como índice do sujeito o (IS3s) e está à esquerda do verbo na função de sujeito. Enquanto o da primeira pessoa do singular mé'me'(IO1s) aparece, à direita e imediatamente depois do verbo em função de objeto. Na nossa análise os 'prefixos objetos' serão tratados como índices do objeto (IO).

A língua leke (C14) apresenta alternativamente frases do tipo àdèzéíngá 'ele me fez chorar' e àmómbédé 'ele me mandou chamar' onde o pronome substituto posposto alterna 
com o 'prefixo do objeto' da primeira pessoa do singular - $\grave{n}$ - Esse 'prefixo' é o único que existe para as pessoas nessa língua, enquanto todos os 'prefixos objetos' das classes e todos os reflexivos são atestados.

A tendência geral, exceto em lembaama, é a de se fazer uso do mesmo 'prefixo objeto' da segunda pessoa do singular para a segunda pessoa do plural. Assim, mbole-tooli (C60) tem -ò- e -ò-; mpundza, mbonji e balobo (C30 ngiri) têm -bo- e-bo-; lifonga, likata, libobi e lobala (C30 ngiri) têm -e- e - e-. A confusão formal pode ir até mais longe nas línguas do grupo ngiri (C30) onde de acordo com Motingea (1996), a língua kunda tem o mesmo 'prefixo objeto' -mo- para a primeira pessoa do plural, a segunda pessoa do singular e do plural, e para a classe 1; enquanto em babale, -mo- é usado na classe 1 e na segunda pessoa singular e plural.

O 'prefixo objeto' da primeira pessoa do singular é geralmente uma consoante nasal; o da primeira pessoa do plural é, normalmente, -to-, mas encontramos -lo- em zamba, loi e mbonji que é o 'prefixo objeto' da segunda pessoa do plural em bolia (C35), em nkengo e nkundo (C60) ou em kela (C75). É de longe o 'prefixo objeto' reflexivo que tem as formas mais particulares. Os dois predominantes nas línguas bantas da floresta são -yá-, que pode ser encontrado em leke (C14), ntomba (C35), nas língua do grupo mongo (C60), kela (C75) ou tetela (C71), e -mí- que aparece nas línguas do grupo ngiri (C30). Encontramos alternativas desse morfema em outras línguas. Assim, doko (C40) tem -mí- ou -má-; e -ma- é a única forma citada na língua motembo do grupo ngiri (C30). Muitas formas isoladas podem também ser mencionadas, como -ka- em bolia (C35), -k亡̌- em bira (D32) ou formas do tipo vocálico como -á- em mbudza, língua do grupo ngiri (C30) ou -é- em boa (C44) e beo (C45).

De acordo com a autora, os 'prefixos objetos' têm tom baixo para pessoas e para a classe 1, no entanto, o tom é alto nas outras classes, ou têm tom baixo para as pessoas do singular e para a classe 1, mas alto para as pessoas do plural e para as outras classes. Em lembaama, observamos o contrário: o tom dos índices objetos é geralmente alto.

\section{c) A derivação}

A derivação verbal diz respeito ao tipo de sufixos que, quando acrescentados a uma raiz verbal, mudam o seu sentido. São chamados de 'extensões' verbais pelos bantuístas. Esses sufixos indicam várias relações como a transitividade, a reciprocidade, a frequência, voz passiva, a causa, etc. As línguas bantas da floresta têm poucos sufixos derivacionais 
comparando com as línguas bantas do centro ou do sul do continente africano. São encontrados em quase todas as línguas da floresta: o sufixo aplicativo (-ee-, -e-), o sufixo recíproco -an-, o sufixo estativo (que indica duração, estado permanente) -am-,-em-, às vezes - Vm-, o par de sufixos reversivos: o transitivo -ol- e o intransitivo -o-, e o menos frequente sufixo neutro -eg-, -ik-, ou -i-. O sufixo longo causativo do tipo -is-, -ih-, -es- é atestado na maioria dessas línguas, particularmente em duтu (B63), leke (C14), balobo, lilenge, kunda, mbonji, zamba, lobala, libobi, lifonga (C30 ngiri), doko (C40), boa (C44), beo (C45), tofoke (C53), lombo (C54), kele (C55), mbole-tooli (C60), mituku (D13), bira (D32) e bodo (D35).

O sufixo causativo coexiste com a forma longa encontrada em beo ou leke, e parece predominante nas línguas bantas do centro sul, como ntomba e bolia (C35), as línguas do grupo mongo (C30), etc. A língua pove (B22c), tem o sufixo derivativo causativo $-i$ - e a sequência -id-i- enquanto tsogo (B31) tem -éd- e um sufixo aplicativo -é- (por exemplo: èkàdàmèdì 'ele tem uma cicatriz'; màbòkáméì 'levantei meus olhos para..., 19 .

As línguas bantas da floresta expressam frequentemente a voz passiva por meio de formas verbais derivadas com o sufixo -am-. O sufixo passivo do tipo - $u$-, - $i b u$ - é raro entre essas línguas, embora ele tenha sido encontrado na zona B (pove B22c, tsogo B31), nas línguas do grupo ngiri C30 onde temos - $u b u$-, -iubu- na língua mpunza, no grupo C40 onde temos - $u$ - na língua beo $\mathrm{C} 44$, e no grupo C40 onde temos -o- na língua kele C55.

Sequências de sufixos derivacionais têm sido atestadas em todas as línguas (a única dificuldade está em encontrá-las) e certas descrições dão inúmeros exemplos que demonstram a produtividade do micro-sistema da derivação nas línguas bantas. Em lembaama, atestamos a existência de uma dezena de extensões que indicam: a transitividade, a voz passiva, a frequência, a reflexividade, a reversividade, o benefício, a posição, o instrumento, o resultado e a diferença entre uma ação humana e natural (cf. Capítulo IV sobre a derivação verbal).

\footnotetext{
${ }^{19}$ Lembramos que pove e tsogo, assim como lembaama (B62) são línguas faladas no Gabão.
} 


\section{Capítulo II - PRINCIPAIS CARACTERÍSTICAS DA FONOLOGIA E DA MORFOLOGIA NOMINAL DO LEMBAAMA}

Lembramos nesta parte alguns dados essenciais da fonologia do lembaama, úteis para a leitura e a compreensão dos fatos gramaticais deste trabalho.

\section{Os tons}

Língua tonal pode ser definida como aquela em que uma comutação fonologicamente limitada à altura ou à melodia de uma única sílaba ou mora é susceptível de construir a única marca de uma comutação entre duas unidades significativas mínimas (CREISSELS, 1994, p. 175).

Vejamos estes exemplos:

mvá 'cachorro'

mvà 'como'(comparativo).

A língua lembaama possui dois tons pontuais, notados como se segue:

ハソ 'baixo', que notamos igualmente pela letra B

I'I 'alto', que notamos igualmente pela letra A

Não encontramos combinação de tons no mesmo segmento em lembaama, que constituiriam o que a literatura denomina tons de contorno ou tons modulados.

\section{As consoantes}

O sistema consonântico comporta 43 consoantes (cf. Quadro 1, abaixo). Dessas 43, apenas /g/ se realiza [₹]. Ele aparece apenas na posição intervocálica. No dialeto lembere, /r/ se realiza [d] na posição intervocálica. Vejamos estes exemplos: 
(2a)

lempiini [taara]'pai'

(2b)

lembere [taada] 'pai'

Quadro 1: quadro fonológico das consoantes

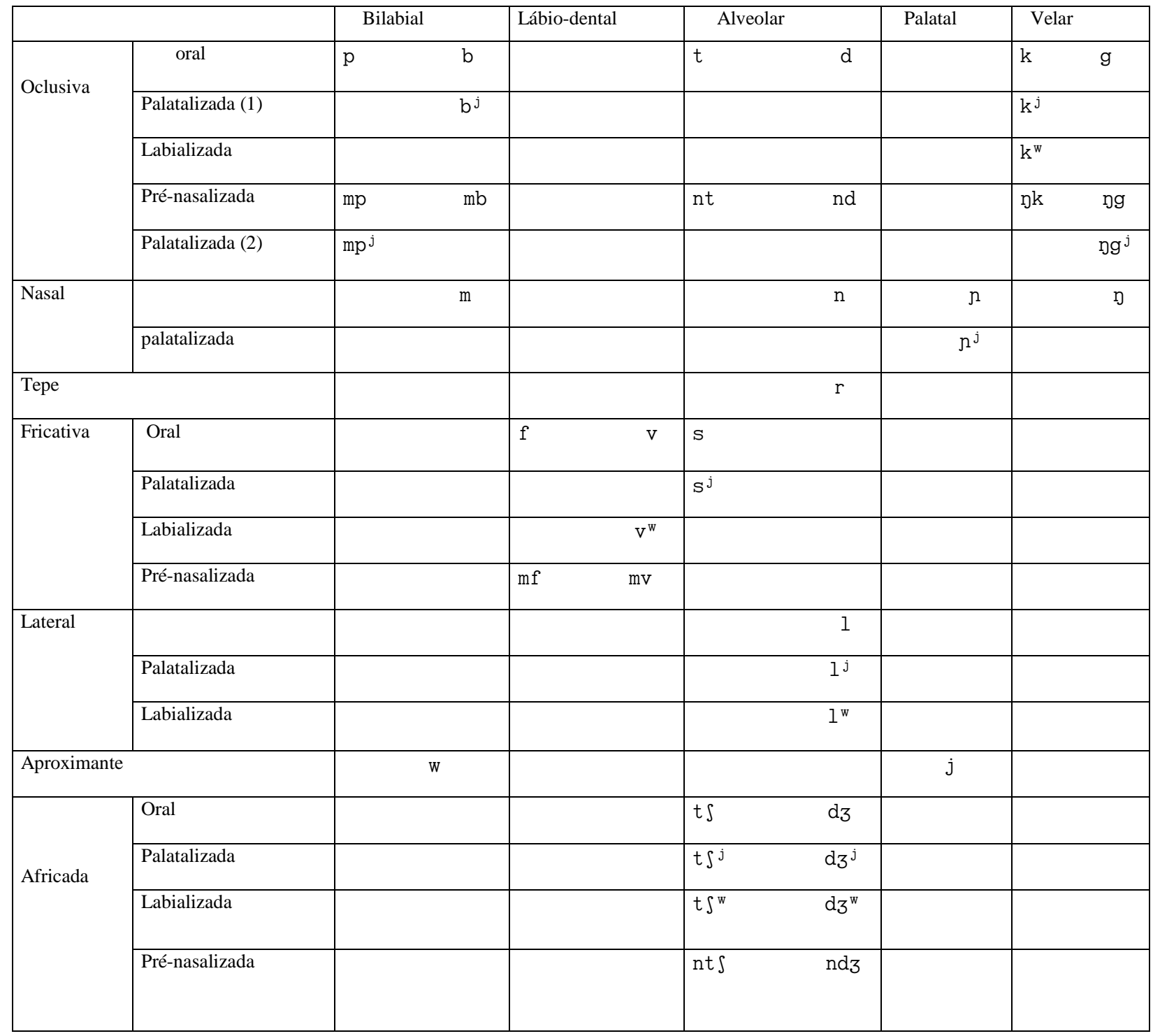

Nosso trabalho é foneticamente transcrito com anotações de tons (como mencionado no item acima) e indicação de algumas elisões pelo sinal do apóstrofo. Por outro lado, fizemos uma transcrição fonológica das consoantes labializadas e palatalizadas. O alfabeto usado para as transcrições é o Alfabeto Fonético Internacional (International Phonetic Alphabet-IPA) de 1993, corrigido em 1996. Com relação à representação dos dois tons do lembaama, para facilitar a leitura dos exemplos do texto, só marcaremos o tom alto, representado pelo acento 
agudo. Já no corpus, os dois tons, alto e baixo, são respectivamente representados pelos acentos agudo e grave. Na transcrição dos exemplos, daremos na primeira linha o enunciado em lembaama, na segunda linha, a segmentação morfológica; na terceira, faremos a descrição gramatical e a tradução dos elementos do enunciado. Finalmente, na quarta linha, daremos a tradução do sentido do enunciado em português.

\section{As vogais}

O sistema vocálico é composto de 14 vogais que se diferenciam pela sua duração. Assim, o sistema vocálico se desdobra em dois subsistemas de 7 vogais, um das vogais breves e outro das vogais longas, apresentados abaixo em quadros, respectivamente:

\section{Quadro 2: Quadro fonológico das vogais breves}

\begin{tabular}{|l|c|c|c|}
\cline { 2 - 4 } \multicolumn{1}{c|}{} & Anterior & Central & Posterior \\
\hline Fechada & i & & $u$ \\
\hline Meio-fechada & e & & 0 \\
\hline Meio-aberta & $\varepsilon$ & & 0 \\
\hline Aberta & & a & \\
\hline
\end{tabular}

\section{Quadro 3: Quadro fonológico das vogais longas}

\begin{tabular}{|l|c|c|c|}
\cline { 2 - 4 } \multicolumn{1}{c|}{} & Anterior & Central & Posterior \\
\hline Fechada & ii & & uu \\
\hline Meio-fechada & ee & & oo \\
\hline Meio-aberta & $\varepsilon \varepsilon$ & & o० \\
\hline Aberta & & aa & \\
\hline
\end{tabular}

Em lembaama, a distinção entre as vogais longas e breves é pertinente. As vogais longas nunca aparecem no início de um substantivo, nem de um verbo.

Observa-se às vezes uma harmonia pela repetição das vogais idênticas. Trata-se de um fenômeno reconhecido sob nome de harmonia vocálica, tal como ocorre na harmonia da vogal $o$ nas seguintes palavras: obolo 'apodrecer' e okolo 'cansar'. 
O fenômeno da elisão é também uma característica marcante das vogais do lembaama, principalmente quando elas se encontram entre duas palavras, a primeira se elide em benefício da segunda. Vejamos este exemplo:

(3) ndé a dzá $\rightarrow$ nd’ádzá ‘ele(a) come’

Existem outros fenômenos fonológicos que afetam as vogais do lembaama. São eles: a semivocalização que ocorre quando V1 é mais alta que V2; o alongamento que ocorre quando vogais são idênticas dentro de um prefixo de classe e entre dois lexemas. Nesse caso não há elisão. Vejamos alguns exemplos:

\section{a) Semivocalização}

(4)

$$
\begin{aligned}
& \text { mù- áná } \longrightarrow \text { mwáná 'criança' } \\
& \text { 1- criança } \\
& \text { / u / } \longrightarrow \text { w/_ [v] }
\end{aligned}
$$

A vogal $/ u /$ se transforma em semivogal diante de uma outra vogal. Mas não encontramos exemplos de $/ \mathrm{i} / \longrightarrow \mathrm{j} / \longrightarrow[\mathrm{v}]$

\section{b) Alongamento}

(5)

$$
\text { bá + áná } \longrightarrow \text { báá ná 'crianças ou filhos' }
$$

2- criança

(6)

$$
\begin{aligned}
& \text { à- bárá + á + bó } \longrightarrow \text { ábáráábó 'as facas deles' } \\
& \text { 9- facas de ele(a)s } \\
& \text { V1+V1 } \longrightarrow \text { V1: }
\end{aligned}
$$

Uma vogal se alonga em contato com outra vogal idêntica (OKOUDOWA, 2005, p. $41-42)$. 


\section{A sílaba}

No lembaama, a configuração da sílaba é geralmente do tipo $(\mathrm{C}) \mathrm{V}$, e aberta. É por isso que a língua procura evitar encontros consonantais. $\mathrm{O}$ ataque permite apenas uma consoante. Há também presença de uma nasal silábica que serve de prefixo nominal na classe 10, que representa o plural da classe 9 (cf. Quadro 4).

\section{As classes nominais}

O sistema de classes nominais é uma das características comuns às línguas bantas. Esse sistema é baseado na repartição dos substantivos em prefixos. Esses prefixos nominais por sua vez são repartidos em grupos ou classes sob a base do emparelhamento singular / plural. Segundo Bonvini (1996, p. 79), o sistema classificatório do substantivo, próprio ao tronco nigero-congolês, está também, embora logicamente independente, diretamente relacionado ao sistema de concordância que caracteriza uma proporção importante das línguas desta família. Neste sistema, o substantivo, integrado no sistema classificatório e em função das marcas de classes, gera tanto o mecanismo de determinação que opera no nível do constituinte nominal quanto aquele que opera sobre as funções sintáticas no nível da oração. Daí a noção de "classe de concordância".

Quando se trata de determinação nominal, a concordância se manifesta habitualmente da seguinte maneira: o substantivo, em função de determinado, escolhe os determinantes, simples (demonstrativo, interrogativo, definido, qualificador, ou complexos (substantivo + um constituinte nominal, um adjetivo, uma preposição).

Quanto à concordância no nível da oração, ela se manifesta geralmente nas escolhas dos índices pronominais ligados ao predicado verbal: esses estão relacionados simultaneamente ao sistema de afixos flexionais, que caracterizam o substantivo, e à função sintática que ele exerce na oração; embora teoricamente os dois sistemas sejam diferentes e independentes.

O lembaama tem cinco categorias de classificadores:

1- o prefixo nominal (PN) que marca o substantivo;

2- o prefixo do adjetivo (PA) que marca o adjetivo;

3- o conectivo (Con) que representa o genitivo;

4- o índice do sujeito (IS) que marca o sujeito do verbo; 
5- o índice do objeto (IO) que marca o complemento do verbo.

A forma desses classificadores varia de acordo com a classe da palavra que eles classificam, ou com a qual eles se relacionam ou concordam na oração (OKOUDOWA, 2005, p. 30).

Num total de 12, as classes nominais não coincidem com as 7 indicadas por Adam e Biton (1969) e nem com as 15 identificadas por Blanchon e Alihanga (1992). Os prefixos nominais são do tipo CV-, V-, N- (nasal silábica), Ø-(zero) e têm um tom baixo em geral, exceto para as classes 2, 5 e 6 . Contrariamente a outras línguas bantas, não há uma classe reservada para lugares (classe do locativo): para tanto, a língua lembaama usa morfemas independentes que funcionam como preposições. Vejamos este exemplo:

m’édze ntsá ndzó

mé $\quad$ e $\quad \varnothing-\quad d z \quad \varepsilon \quad$ ntsá $\varnothing-$ ndzó

1s IS1 Pres ir VF prep 7 casa

'vou dentro de casa'

Abaixo, no Quadro 4, apresentamos os prefixos de classe nominal identificados em lembaama: 
Quadro 4: classes nominais do lembaama

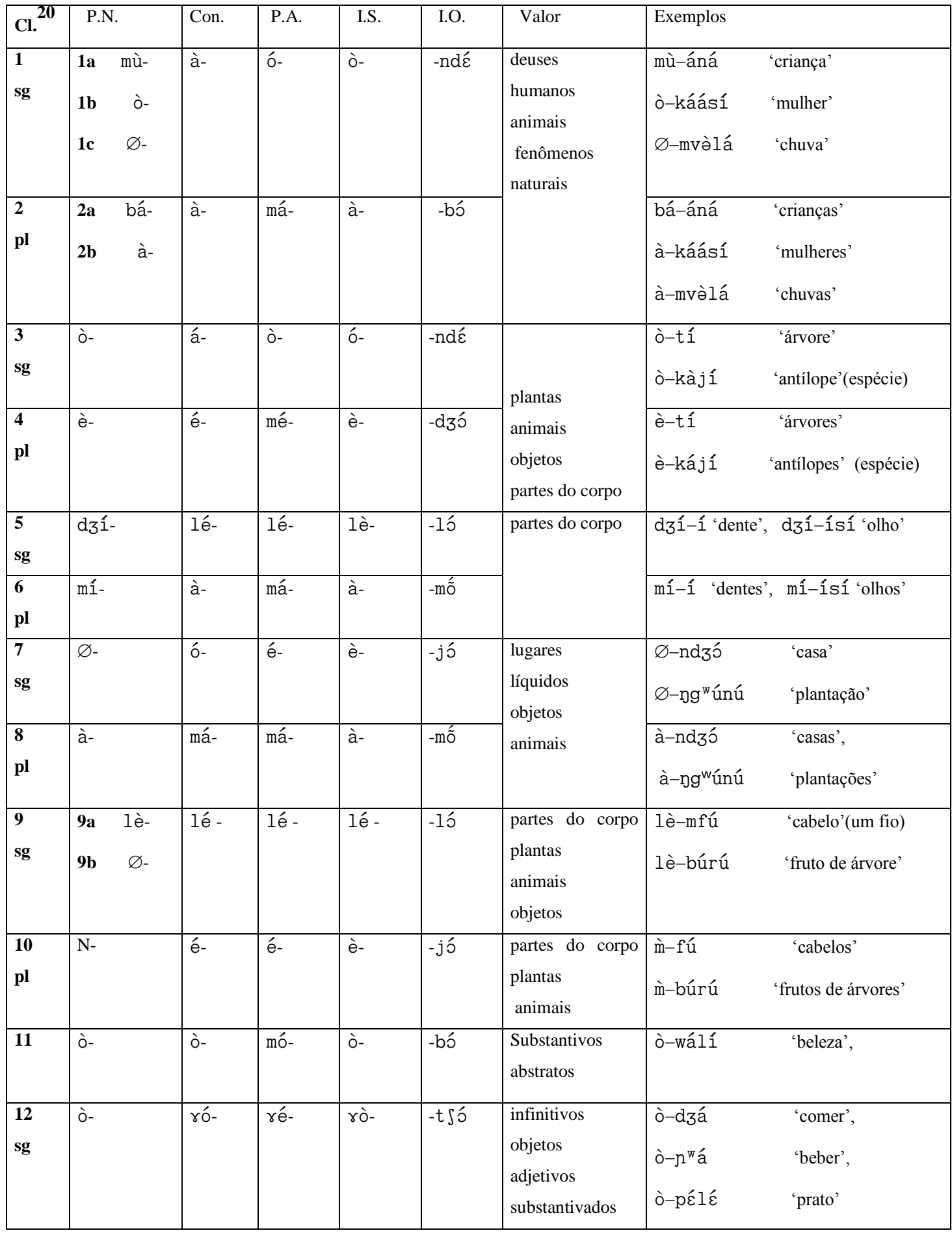

\footnotetext{
${ }^{20}$ Abreviações: $\mathrm{Cl}$ : classe $\mathrm{PN}$ : prefixo nominal

P.A: Prefixo do Adjetivo

IS: índice do sujeito IO: índice do objeto Con.: conectivo 


\subsection{Organização do quadro 4}

É possível proceder à leitura desse Quadro em dois eixos: num eixo vertical, a leitura é paradigmática. Ela serve para distinguir os nominantes ${ }^{21}$ segundo o tipo de unidades com as quais eles se juntam na formação de um substantivo e de uma oração indicando preferencialmente o número, singular ou plural. O eixo horizontal é sintagmático. Ele serve para distinguir os diferentes elementos de uma expressão ou de uma oração. As colunas mostram os prefixos segundo sua relação na composição dos substantivos e da oração, ou seja, segundo sua concordância com um núcleo nominal.

Só a consideração desses dois eixos permite a identificação da classe de um morfema. Por exemplo, apesar da sua semelhança formal, os prefixos das classes 3, 11, e 12 se encontram em três classes distintas, já que cada um deles estabelece concordância (no nível sintagmático) diferente, manifestada por índices e prefixos distintos para cada classe. Vejamos alguns exemplos de classes:

Classe1 - classe dos substantivos que denominam deuses, seres humanos, animais, fenômenos naturais. Singular.

L.1. muáná a me okáásí omìja bîílá ndé

L.2. /mu- áná / a- /me /ó- káásîl o /mí / ja || bîílá / ndé

L.3. /PN- criança/ Con- de /1s-eu / PA- mulher / IS-ela / P1 / chegar || imp. Sg-chamar/ IO- a

L.4 . 'A minha filha chegou. Chame-a!'

(9)

Classe 2 - plural da classe1.

L.1. bááná ame mákáásí amíja bíílá bó

L.2. /bá- áná / a- /me /má- káásîl a /mí / ja |l bîílá / bó

L.3. /PN- crianças /Con- de /1s-eu /PA- mulheres/ IS- elas / P1 / chegar || imp.Sg-chamar / IO- as

L.4 'As minhas filhas chegaram. Chame-as!'

Essas duas primeiras classes (singular e plural) formam o gênero I. Denominação utilizada pelos bantuístas para indicar o emparelhamento singular/plural (SG/PL). A língua

\footnotetext{
${ }^{21}$ Entendemos por nominantes todos os afixos ou morfemas que determinam a classe dos nomes. Em lembaama, ele está sempre prefixado na base (raiz) do item lexical.
} 
lembaama apresenta 12 classes nominais e 9 gêneros, conforme apresentado no Quadro 5 abaixo:

Quadro 5: Gêneros e classes nominais do lembaama

\begin{tabular}{|l|l|}
\hline GÊNERO I & Classes 1 e 2 \\
\hline GÊNERO II & Classes 3 e 4 \\
\hline GÊNERO III & Classes 5 e 6 \\
\hline GÊNERO IV & Classes 7 e 8 \\
\hline GÊNERO V & Classes 9 e 8 \\
\hline GÊNERO VI & Classes 9 e 10 \\
\hline GÊNERO VII & Classes 7 e 4 \\
\hline GÊNERO VIII & Classes 11 e 4 \\
\hline GÊNERO IX & Classes 12 e 4 \\
\hline
\end{tabular}




\section{Capítulo III - ESTRUTURA DO VERBO EM LEMBAAMA}

\section{Introdução}

Segundo a tradição bantuísta iniciada por A. Meeussen no seu trabalho "Essai de grammaire rundi", publicado em 1959, o verbo tem a seguinte estrutura nas línguas bantas (teoricamente, porque nem sempre se realiza):

1.pré-inicial

2.inicial

3.pós-inicial

4. marca

5. infixo

6.radical

7.sufixo

8.final

9.pós-final

Essa apresentação foi reformulada por Nurse (2008) como segue:

1.pré-inicial

2.inicial

3.pós-inicial

4.formativo

5.limitativo

6.1.infixo

6.2.radical

6.3.sufixo (extensão)

7.pré-final

8.final ou vogal final

9.pós-final

Como podemos observar nessas duas apresentações da estrutura do verbo banto, há uma diferença de nomenclatura e de classificação entre a descrição de Meeussen (1959) e a de Nurse (2008). As principais diferenças são:

- na posição 4, o que Meeussen chama de marca, Nurse chama de formativo. 
-a posição 5 é ocupada pelo infixo no esquema de Meeussen. Enquanto para Nurse, ele está na posição 6.1 .

- a posição 6 para Meeussen é somente ocupada pelo radical. Enquanto para Nurse, essa posição é subdividida em três partes: 6.1. Infixo, 6.2. Radical, 6.3. Sufixo (extensão).

- a posição 7 para Meeussen é ocupada pelo sufixo. Para Nurse, ela é ocupada pela pré-final. Sendo que esse termo não é só uma redenominação, mas trata-se de uma posição não identificada por Meeussen e que, portanto, não fazia parte da estrutura que ele apresentou.

Finalmente, temos um total de onze posições na estrutura do verbo banto estabelecida por Nurse. Ou seja, às 9 posições iniciais definidas por Meeussen, Nurse acrescentou duas ao subdividir a posição 6 em três partes. De fato, podemos observar que as posições 5,6 e 7 de Meeussen foram interpretadas por Nurse como uma só posição, onde estão as informações propriamente verbais: o infixo, o radical e a extensão. Houve, portanto, uma certa reformulação da proposta de Meussen, ao agrupar essas três posições.

Quanto a nós, como a nossa preocupação neste capítulo é de apresentar a estrutura do verbo banto em geral e a do lembaama em particular, pensamos que é importante mostrar as duas principais classificações: a mais antiga, a do pioneiro Meeussen, e a mais recente, a de Nurse. Escolhemos a estrutura do verbo banto revista por Nurse como modelo para nossa análise da estrutura verbal do lembaama por concordarmos com a reorganização proposta principalmente no que se refere à parte nuclear do verbo: o infixo, o radical e a extensão. É nessas posições que o verbo costuma codificar várias informações que dizem respeito ao tempo, ao modo e à semântica do verbo. Por exemplo, em lembaama, a marca de tempo aparece logo antes do radical e os sufixos derivativos ou extensões juntam-se à raiz do verbo para formar o radical, acrescentando um novo significado ao verbo (cf. Capítulo IV sobre a derivação verbal). Isso é bem claro no esquema do Nurse. O esquema de Meeussen é mais genérico, não especificando a extensão nem a final, que veiculam informações fundamentais e cruciais no verbo banto em geral. Em lembaama, como veremos, a vogal final indica o aspecto (cf. capítulo V sobre o Tempo, o Aspecto e o Modo).

Para ilustrar a estrutura do verbo banto, Meeussen (1959) dá o seguinte exemplo, em quirundi (D62), em que a posição 3 (a pós-inicial) não ocorre: 
(1)

$\begin{array}{llllllll}\text { Nti }- & b a- & z o ́ o- & t u- & \text { hit }- & \text { ir }- & a- & \text { mwó } \\ 1 & 2 & 4 & 5 & 6 & 7 & 8 & 9 \\ \text { Neg1 } & 3 \mathrm{p} & \text { Fut } & 1 \mathrm{p} & \mathrm{Rad} & \mathrm{Ext} & \mathrm{VF} & \mathrm{Neg} 2 \\ \text { 'Eles não escolherão por nós' }\end{array}$

Nesse exemplo, os elementos se seguem numa ordem fixa. A posição 1 é ocupada pela negação 1 (Nti- 'não'). A posição 2 representa a inicial que é pronome (índice) de terceira pessoa do plural (-ba- 'eles'). A posição 4 representa o marcador do futuro (-zôo-). A posição 5 representa o infixo que é aqui um pronome objeto da primeira pessoa do plural (-tu- 'nós'). A posição 6 é o radical do verbo (-hit- 'escolher'). A posição 7 representa o sufixo que aqui é uma extensão que expressa a transitividade (-ir-). A posição 8 representa a final, ou seja, a vogal final do verbo $(-a)$. Finalmente, a posição 9 representa a pós-final que expressa a segunda negação (-mwó 'não'). Com um certo cuidado, podemos afirmar que a pré-inicial e a pós-final são tratadas como não estando estritamente ligadas à palavra verbal como o são o índice do sujeito - ba- e a extensão -ir- que são obrigatórios nesse caso.

A partir de agora, trataremos da estrutura verbal proposta por Meeussen sob a óptica de Nurse. Assim sendo, o radical, posição 6.2 da estrutura de Nurse, é uma parte completamente aberta, ampla por ser lexical. Ela pode aceitar empréstimos de novos verbos oriundos de outros idiomas, mas preservando a morfologia do verbo na língua banta acolhedora. Por exemplo, em lembaama, os verbos no infinitivo têm $o$ - como prefixo e - $a$ como sufixo, que pode ser verificado no verbo 'ler', o-liir- $a$, emprestado do francês 'lire'. As outras posições como a inicial (posição 2), a pós-inicial (posição 3), o limitativo (posição 5), o infixo (posição 6.1), o sufixo ou a extensão (posição 6.3), a pré-final (posição 7) e a final ou a vogal final (posição 8) são mais ou menos fechados, isso porque, no decorrer dos séculos, essas partes do verbo permitiram a formação de novos alomorfes. A pré-inicial (posição 1), o formativo (posição 4), e a pós-final são também posições que permitiram a aparição de novos membros no decorrer dos séculos, principalmente pela incorporação de um novo material por empréstimos ou por gramaticalização. Como é o caso comum em muitas línguas do mundo, de verbos como ir, ficar, acabar assumirem o papel de verbo auxiliar na formação de tempos compostos.

Apresentamos, na sequência, uma análise de cada uma das posições da estrutura do verbo banto acompanhada de ilustrações de algumas línguas bantas (Nurse, 2008: 32-39) e de exemplos do lembaama. 


\section{A pré-inicial}

Meeussen coloca dois morfemas possíveis na pré-inicial porque são as categorias que preenchem esta posição. Trata-se da primeira negação e do relativo. O exemplo (1) do quirundi (D62), aqui renumerado, ilustra esse fato:

(2) Nti - ba - zóo - tu - hit - ir - a- mwó

$\begin{array}{llllllll}1 & 2 & 4 & 5 & 6 & 7 & 8 & 9\end{array}$

Neg1-3p. -Fut- 1p. -Rad. -Ext.- VF- Neg2

'Eles não escolherão por nós'

As formas negativas que ocorrem na maioria das línguas bantas na pré-inicial seriam reflexos do morfema reconstruído como $*(n) k a$-, embora tenha outras formas como $*(n) t a$-, $* t i-/ c i$, e *(n)tI que ocorrem também. A forma do relativo concorda com a classe do núcleo nominal da frase. É o caso dos exemplos ${ }^{22}$ das línguas bushoong e lega renumerados abaixo (NURSE, 2008, p. 32):

(3) bushoong (C83)

a) Frase afirmativa:

t- -a- bók nyam

1p PFTV fuzilar animal

'nós fuzilamos o animal'

b) Frase negativa:

ka- $\quad$ - - a- bók nyam

NEG 1p PFTV Fuzilar animal

'Não fuzilamos o animal'

A segunda categoria ou o segundo morfema que pode ocupar essa posição é o relativo. Por exemplo:

\footnotetext{
${ }^{22}$ As glosas foram acrescentadas.
} 
(4) $\operatorname{lega}(D 25)$

nnyama zi- ba- ta- gik- é zábolé

9carne 9REL- 2- NEG2 Cozinhar- VF apodrecerá

'A carne que eles não cozinharem apodrecerá'

O relativo concorda com a classe do antecedente (nnyama 'carne') que deve ser da classe 9.

1.1 A pré-inicial em lembaama

Em lembaama, na pré-inicial só ocorre o relativo. O exemplo lega (D25) acima, traduzido para o lembaama seria:

(5) Frase com relativo

nam’ábomakalaamádzuání ,

ø-nama a bó- ma- ka- laam- -á dzuá ní

1-carne 1REL- $3 p \quad$ IS NEG cozinhar VF DEM NEG

'A carne que ele(a)s não cozinharem,

ádzero-bolo

á- $d 3_{-} \varepsilon$ o-bol- o

IS ir VF 12-apodrecer VF

vai apodrecer'

O exemplo acima deixa claro que, em lembaama, o relativo aparece na posição préinicial, e concorda em classe com o antecedente.

\section{A Inicial}

Este é o lugar do sujeito que geralmente precede o verbo na maioria das línguas bantas. O sujeito, quando lexical ou pronominal, em algumas línguas, como lembaama, é retomado por um morfema que representa a concordância obrigatória entre o sujeito e o 
verbo. Esse morfema é o Índice do Sujeito (IS), também denominado Marca do Sujeito (MS). Entretanto, existem línguas bantas que não marcam o sujeito por um índice (esteja ele sob forma lexical ou pronominal). Vejamos o exemplo ${ }^{23}$ da língua setsuana (ou tsuana) que apresenta um sujeito sem índice na sua concordância com o verbo:

(6)

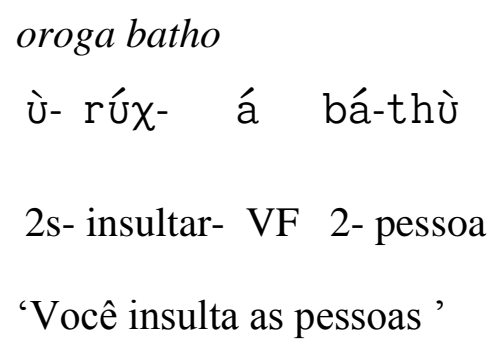

Como podemos observar nesse exemplo, depois da segunda pessoa do singular que é o sujeito, não temos nenhum morfema antes do verbo. Portanto, o sujeito não é retomado por morfema nenhum, ou seja, não há índice do sujeito nesse exemplo do tsuana.

Há línguas que colocam a marca do sujeito à direita da raiz verbal, como os clíticos e os pronomes nas relativas. No exemplo (7c). abaixo, em protobanto, reconstruído por Meeussen (1967:112-113 apud NURSE, 2008, p. 33), seria possível substituir o substantivo muntu 'pessoa', por um clítico pós-verbal ou por um pronome:

mu- ntu a- $\quad$ - $\quad$ dim- a $\quad$ i- pía

1 pessoa IS1 zéro cultivar VF 5 horta

'A pessoa cultiva a horta'

mu- ntu ju- $\quad$ j- dim- a i- pía

1 pessoa REL.3s zéro cultivar VF 5- horta

'A pessoa que cultiva a horta'

\footnotetext{
${ }^{23}$ Exemplo extraído de Creissels (2004:6).
} 
(7c). Exemplo com muntu 'pessoa' como sujeito do verbo dima 'cultivar'

i- pía di- ø- dim- a mu- ntu

5 horta REL5 zero Cultivar VF 1 pessoa

'A horta que a pessoa cultiva'

(7d). Exemplo com pía 'horta' como objeto do verbo dima 'cultivar'

mu- ntu ju- tú- ø- dim- il- á- i- pía

1 pessoa REL3s $1 \mathrm{p}$ zéro Cultivar para VF 5 horta

'A pessoa para a qual cultivamos a horta'

Substituir o sujeito lexical por um pronome é possível em algumas línguas bantas. Meeussen não dá exemplo nesse caso, mas Nsuka Nkutsi (1982, p. 248) dá o seguinte exemplo (sem glosa) na língua bolia (C35b):

nyama ěbáátákí bonto

nyama ěbáátákí bonto

animal (Objeto) Verbo homem (Sujeito)

'o animal que o homem teve'

nyama ěbáátákí ndé

nyama ěbáátákí ndé

animal (Objeto) Verbo 3s (Sujeito)

'o animal que ele teve'

De fato, no exemplo (8a) acima, podemos ver que o substantivo bonto 'homem', que desempenha o papel de sujeito nessa oração, aparece à direita da raiz do verbo. No exemplo (8b), vemos que esse substantivo pode ser substituído por um pronome da terceira pessoa do singular ndé 'ele' que continua desempenhando o papel de sujeito e que continua à direita da raiz verbal. 
Nas relativas, a inicial contém, ao lado do sujeito, a marca do objeto se o objeto não estiver ligado ao verbo.

Outro caso em que o sujeito aparece depois do verbo, é o da inversão que se faz, geralmente, com locativos, a chamada 'inversão locativa'. A expressão do locativo parece ter se movido do seu lugar original (pós-verbal) para uma posição pré-verbal deslocando o sujeito para uma posição pós-verbal. A estrutura verbal da construção invertida é a mesma de uma construção verbal não invertida. Vejamos alguns exemplos na língua chewa ou cicewa (N31b) tirados de Bearth (2003, p. 139) apud Bresnan e Kanerva (1989, p. 2):

(9a)

a lendô-wo a-na bwér-a ku-mu dzi

2 visitante aqueles 2 pass vir VF Loc(17)-3 vila

'Aqueles visitantes que vieram na vila'

ku-mu dzi $k u-n a$ bwér-a a lendô-wo

Loc(17)-3 vila 17 pass vir VF 2 visitante aqueles

'Para a vila vieram aqueles visitantes'

Vemos que no exemplo (9b) a concordância é feita entre a classe do locativo (classe 17) que está na posição inicial e o índice do sujeito ou marcador do sujeito (17). Vejamos um outro exemplo na mesma língua:

M-mi têngo mw-a khal -a a nyáni

18-4 árvore 18- ANT sentar VF 2 babuíno

'Na árvore estão sentados babuínos'

Mas se o verbo 'sentar', cujo particípio passado é usado aqui como adjetivo, for substituído por um verbo numa forma ativa, a oração torna-se agramatical. Vejamos este exemplo: 
(11)

*M-mi têngo mu-ku ímb-á a nyáni

18-4 árvore 18- PROG cantar VF 2 babuíno

'Na árvore estão cantando babuínos'

Essas inversões não são possíveis em lembaama. A tradução das orações com inversões acima é inaceitável em lembaama. Vejamos alguns exemplos:

*ó mpuru baari báá a dzí
ó $\quad \varnothing$-mpuru ba-ari báá a dz- í
LOC 7-vila 2-pessoa DEM IS3p vir PFTV

'Para a vila vieram aqueles visitantes'

De fato, a oração acima só seria aceitável se o locativo e o lugar ó mpugu 'na vila' estivessem no final, isto é, depois do verbo. O mesmo acontece com a oração abaixo. Vejamos mais um exemplo:

*ójul’ótî a lí m’ántsí åankímá

ó júlá ó-tí a l- í má ánt

Loc sobre 3-árvore IS2 estar PFTV Loc sentado 2-babuino

'Na árvore estão sentados babuínos'

ánkím’á lî m’ạntsî ójul’ótí

a-pkímá a l- î má åantsí ó júlá ó-tí

2-babuino IS2 estar PFTV Loc sentado Loc sobre 3-árvore

'Os babuínos estão sentados na árvore' 


\subsection{A Inicial em lembaama}

Em lembaama a posição inicial é ocupada pelo índice do sujeito. Exceto na primeira pessoa do imperativo, o IS está sempre presente nas formas verbais:

(13a)

mvuur 'ákúná ngwúnú

mv- uuru á- kún- á ø- ggwúnú

1 pessoa IS1 cultivar VF 7 plantação

'A pessoa cultiva a plantação'

(13b)

báári mákúná jgwúnú

ba- ari má- kún- á ø- Đgwúnú

2 pessoa IS2 cultivar VF 7 plantação

'As pessoas cultivam a plantação'

(13c). Imperativo singular

ø- dz- á

Zero.2s comer VF

'coma!'

(13d). Imperativo plural

le- dz- á

IS. $2 \mathrm{p}$ comer VF

'comam!' 


\section{A Pós-inicial}

O único morfema que ocorre nesta posição é o morfema da negação secundária que não aparece com a negação primária. A segunda negação foi provavelmente associada com contextos de orações não-principais, relativas, com verbos no imperativo e subjuntivo.

Os morfemas mais comuns que representam a segunda negação são reflexos de *-tí-; reflexos de $*_{-t a ́-}\left(\mathrm{cf}\right.$. a língua lega), ${ }^{*}-k a-,{ }^{*}$-ca-, e *-na- (com tom desconhecido) também ocorrem (e nessa ordem de frequência). O exemplo na língua zalamo (G33) apresentado por Nurse (2008, p. 34):

$$
\begin{array}{lll}
\text { (14) u- } & \text { si- } \quad \text { gul- } \quad \text { e }(* t i>s i) \\
\text { 2s- } & \text { NEG2-comprar-SBJ }
\end{array}
$$

'Não compre'

Meeussen trata a pós-inicial como uma posição contendo o marcador da negação (sem dizer se se trata da primeira ou segunda negação, de acordo com Nurse), e o formativo contendo os marcadores discretos de tempo e aspecto, portanto possíveis de ocorrer. Isso é verdadeiro nos exemplos (15) e (16). Entretanto, há também casos em que o marcador da negativa não foi acrescentado ao morfema de tempo e aspecto, e sim meramente substituído por ele, como a situação do tsuana estudada por Creissels (1999a). Vejamos os exemplos de Nurse (2008:34) para as línguas londo, babole e nen:

(15a). londo (A11) - Forma afirmativa

$\begin{array}{llll}\text { a- } & \text { mo- } & \text { sak- } & \text { á } \\ 3 \mathrm{~s} & \text { Pas } & \text { procurar } & \text { VF }\end{array}$

'Ele procurou'

(15b). londo (A11) - Forma negative

a- sí- mo- sak- á

3s NEG Pas procurar VF

'Ele não procurou' 
(16a). babole (C101) - Forma afirmativa

a- á dzie- ak- á

3s Pas comer IPFV VF

'Ele comeu'

(16b). babole (C101) - Forma negativa

a- Ka- á- dzíe- ak- á

$3 \mathrm{~s}$ Neg Pas comer IPFV VF

'Ele não comeu'

(17a). nen (A44) - Forma afirmativa

$\begin{array}{llll}m \varepsilon & n a & \text { samb- } & \varepsilon \\ \text { 1s } & \text { P2 } & \text { colocar } & \text { VF }\end{array}$

'Coloquei'

(17b). nen (A44) - Forma negativa

$m \varepsilon$ sá samb- $\varepsilon$

1s P2 colocar VF

'Não coloquei'

Observa-se que a forma negativa distingue-se da afirmativa pelo tom alto na primeira pessoa do singular e pelo morfema sá no lugar de na para expressar o P2 (passado 2). Esses dois morfemas, portanto, acumulam a informação de tempo e de polaridade (afirmação e negação).

\subsection{A Pós-inicial em lembaama}

No caso do lembaama, que tem duas marcas obrigatórias de negação (ka...ni), a pósinicial é $k a$ - (exemplo 18), que deve ser uma herança do morfema *-ka-do protobanto. Vejamos dois exemplos com tempo e aspecto diferenciados pelos tons, marcado no morfema de negação, que também informa tempo e polaridade: 
(18) no passado

mé ká dzá ní

me é- ká- $\quad$ - dz- á ní

1s IS- Neg- zero- comer - VF Neg

'Não comi'

(19) no presente e/ou futuro (próximo)

mé ka dzá ní

me é- $\quad$ ka- $\varnothing-\quad d z^{-} \quad$ á ní

1s IS1s Neg zero comer VF Neg

'Não como /Não vou comer'

De fato, os exemplos acima diferenciam-se pelos tons baixo e alto do morfema $\mathrm{ka}$-. No passado (exemplo (18)), o morfema $k a$ - tem um tom alto, enquanto no presente ou futuro (próximo) ele tem um tom baixo (exemplo (19)). Em lembaama não há um morfema que possa distinguir o presente do futuro nesse caso (Cf. no Capítulo V, sobre Tempo, Aspecto e Modo).

Considerando que as marcas da negação $k a$ e $n i$ formam um morfema descontínuo $k a . . . n i$, esse morfema ocupa duas posições na estrutura do verbo mbaama. São elas: a pósinicial e a pós-final conforme os exemplos (18) e (19) acima.

\section{Formativo}

Esta é a posição dos morfemas de tempo e aspecto, morfemas fundamentais para o verbo. O protobanto tinha uma repartição de funções entre essa posição e a vogal final; repartição pela qual os marcadores de tempo (inclusive na sua ordem) ocorriam na sua maioria nessa posição, enquanto os marcadores de aspecto ocorriam na vogal final. $\mathrm{O}$ formativo, dependendo da língua, também costuma receber marcadores de outras categorias gramaticais, tais como a condição, o modo e o foco.

Dado que a maioria das línguas bantas têm como estrutura silábica canônica $\mathrm{V}, \mathrm{CV}$, $\mathrm{NV}$ ou NCV, a maioria dos morfemas que ocupam essa posição adotam uma dessas estruturas silábicas, e os morfemas com novos papéis gramaticais também tendem a se reduzir a essas 
estruturas. O processo de redução envolvido só ocorre nessa posição e em mais nenhuma outra na língua.

Segundo Nurse (2008), o fato de um morfema ter uma estrutura silábica maior do que a estrutura canônica $(\mathrm{CV})$ pode ser um índice para reconhecer morfemas que estão desempenhando um novo papel gramatical na língua. Os exemplos em lamba (M54), a seguir, mostram isso:

(20a). lamba (M54)

tu- $\varnothing-\quad$ cit- $a$

$1 p-\quad \varnothing-\quad$ fazer- $\quad V F$

'Nós que fazemos'

(20b). lamba (M54)

tw- a:- cit- a

1p- ANT- fazer- VF

'Nós fizemos'

(20c). lamba (M54)

tu- la- cit- a

1p- PRES- fazer- VF

'Nós fazemos'

(20d). lamba (M54)

tu- ka- cit- a

1p- F3- fazer- VF

'Nós faremos' (futuro remoto ou distante)

(20e). lamba (M54)

tw- aku- cit- a

1p- F1- fazer- $\quad \mathrm{VF}$

'Nós faremos'(futuro próximo) 
(20f). lamba (M54)

tu- ci- cit- a

1p- PRES- fazer- VF

'Ainda nós fazemos/ ainda nós estamos fazendo'

(20g). lamba (M54)

tw- luku- cit- a

$1 p-\quad$ IPFV- fazer- VF

'Nós estamos fazendo' (provavelmente $<* 1 \mathrm{i}+\mathrm{ku}$ 'estar em’)

(20h). lamba (M54)

tw- aku- luku- cit- a

1p- F1 IPFV- fazer- VF

'Nós estaremos fazendo'

(20i). lamba (M54)

tw- aku- luku- ci- cit- a

1p- F1 IPFV- Pres- fazer- VF

'Ainda nós estaremos fazendo'

\subsection{O Formativo em lembaama}

Em lembaama, somente o tempo é marcado nessa posição. $\mathrm{O}$ aspecto é marcado na vogal final. Assim, o morfema de tempo é colocado antes do verbo e depois do índice do sujeito (IS) em lembaama, como se pode observar nos exemplos abaixo com o verbo osiasa 'despedaçar um animal':

(21). Oração no passado recente (P1)

bsí lé mísjasa náma

bsí lé mí- sjas- a ø- náma

$1 \mathrm{p} \quad \mathrm{IS} 1 \mathrm{p} \quad \mathrm{P} 1 \quad$ despedaçar $\quad \mathrm{VF} \quad 1-\quad$ animal

'Nós despedaçamos a caça' (Há pouco tempo) 
(22). Oração no passado distante (P2)

loßí bsí le másjasa náma

loßí bsí le má- sjas- a

Hoje 1p IS1p P2 despedaçar VF 1- animal

'Hoje nós despedaçamos a caça' (Há muito tempo)

Como podemos observar, o lembaama, como o protobanto, apresenta morfemas indicadores de tempo que antecedem a raiz verbal. Quanto ao Aspecto, ele é marcado na vogal final (Trataremos desses temas no capítulo V).

\section{O Limitativo}

Meeussen (1967) propõe poucos marcadores nessa posição: -kí- 'persistivo' (marca uma ação que dura) e - $k a$ - que ele chama de 'narrativo', que só ocorrem num número limitado de línguas.

Essa estrutura, segundo Nurse (2008, p. 37), resulta da gramaticalização das primeiras estruturas compostas nas quais o primeiro membro teria sido um verbo auxiliar, e o segundo, um verbo principal. Assim sendo, a proposta de Botne (1999) é de que um - $k a$ - teria derivado de um verbo que significa 'ir'. É o caso na língua yanzi (B85):

$$
\text { baar bá-má ka-kóm }
$$

ba- ar- bá- má- ká- kóm

2 pessoa IS 'just'(ACABAR) ir pagar

'As pessoas acabaram de ir pagar'

Como o limitativo é uma posição que não é obrigatória nem comum na maioria das línguas bantas, lembaama faz parte do grupo daquelas que não preenchem esta posição. 


\section{Infixo}

A posição do infixo contém marcadores dos pronomes objetos, que indicam a concordância com o objeto, que pode ser constituído de um ou mais nomes que seguem o verbo, ou um objeto que foi mencionado anteriormente. As línguas bantas usam três estratégias para marcar os objetos:

1) algumas línguas marcam os objetos nesta posição;

2) outras não permitem marcas nesta posição, mas no final do verbo como clíticos ou pronomes independentes;

3) outras ainda admitem as duas posições (a do infixo e a do final do verbo).

A posição do infixo será referida por IO (Índice do Objeto). Vejamos um exemplo renumerado, em quissuaíli (BEARTH, 2003, p. 123):

(24) quissuaíli (G41-3)

nataka kumwoa

na taka ku- mw oa

(1s) Prog querer Inf IO1 casar

'(Eu) Quero casar com ela'

\subsection{O Infixo em lembaama}

Das três estratégias indicadas acima, a língua lembaama usa a terceira. Isto é, o índice do objeto pode vir antes ou depois do verbo em alguns casos. Vejamos alguns exemplos:

(25a). Afirmação

mwan'átende o sángumu

mu- áná á- ø- tend- $\varepsilon$ o- sångumu

1- filho IS1 zero escrever VF 12 papel

'O filho escreve/ está escrevendo/ vai escrever a carta' 
(25b1). Afirmação

nd' átende t tó

ndé a- $\quad \varnothing-\quad$ tend- $\varepsilon \quad$ tsó

3s IS3s zero escrever VF $\quad$ IO12

'Ele(a) vai escrevê-la / a escreve / está escrevendo-a'

Mas é impossível colocar o IO entre o IS e o verbo:

* (25b2)

ndé á t $\int$ té de

ndé á- tsó tend- $\varepsilon$

3s IS3s IO12 escrever VF

(25c). Interrogação

nd' átende t $\int$ ó ?

ndé á- $\varnothing-$ tend- $\varepsilon$ tsó

$3 \mathrm{~s} \quad \mathrm{IS} 3 \mathrm{~s}$ zero escrever VF $\quad$ IO12

'Ele(a) vai escrevê-la? / a escreve?/ está escrevendo-a?'

Aqui há focalização do índice do objeto. A focalização consiste em assinalar de maneira explícita um constituinte que desempenha o papel discursivo de foco. Segundo Creissels (2006, p. 111), a noção de foco é evidente na resposta às perguntas que incluem pronomes ou advérbios interrogativos: num contexto como esse, só o constituinte que corresponde à pergunta pode ser focalizado. É, portanto, o caso nas interrogações em lembaama acima. O autor (2006, p. 121) distingue três maneiras de focalizar um constituinte sem marca morfológica: só pela entoação, só pela ordem das palavras, ou combinando entoação e a ordem das palavras. De fato, em lembaama, o foco é marcado pela combinação da ordem das palavras e da entoação. A palavra focalizada sempre vem no final da frase. A focalização é sempre reforçada pelo alongamento da vogal final do termo focalizado. No exemplo acima, é a vogal do IO que é alongada. Na ausência de uma palavra interrogativa, há 
sempre focalização do constituinte sobre o qual a interrogação se baseia. Vejamos outros exemplos:

(25d). Interrogação com alongamento da vogal final do verbo. O foco é colocado no verbo.

ndé t $\int$ wátendé ?

ndé tsó á- $\varnothing-$ tend- $\varepsilon \varepsilon$

3s IO12 IS3s zero escrever VF

'Ele vai escrevê-la? / a escreve?/ está escrevendo ela?'

Nesse exemplo (25d), também, o IO não pode vir logo depois do IS. A oração seria agramatical.

Em (25e) temos uma interrogação com foco no pronome da terceira pessoa do singular (ndé 'ele/ela') que se refere a mwáná 'criança' do exemplo (25a), que aparece como dêitico. Há também alongamento da vogal desse pronome dêitico que é o elemento focalizado na sentença (25e) abaixo:

$(25 \mathrm{e})$

átende t $\int o ́$ ndéć ?

á- $\quad \varnothing-\quad$ tend- $\varepsilon \quad$ t $\int \delta$ ndé

IS3s zero escrever VF IO12 3s

'é ele que vai escrevê-la?'

(25f). Afirmação

átende t $\int \check{o}$ ndé

á- $\quad$ - $\quad$ tend- $\varepsilon$ t $\int \delta$ ndé

IS3s zero escrever VF IO12 3s

'é ele que vai escrevê-la'

A afirmação acima (25f), seria a resposta da seguinte pergunta formulada com uma palavra interrogativa: 
$(25 \mathrm{~g})$.

átende tsó ná

á- $\quad \varnothing-\quad$ tend- $\varepsilon \quad$ tsó ná

IS3s zero escrever VF IO12 quem

'Quem (é que) vai escrevê-la'

Numa oração interrogativa negativa, sem palavra interrogativa, a entoação focaliza também a última palavra que é o último elemento da negação (ni) alongando também a sua vogal. Vejamos este exemplo:

$(25 \mathrm{~h})$.

átende t ó ká ndé níí

á- $\varnothing$ - tend- $\varepsilon$ t

IS3s zero escrever VF $\quad$ IO12 Neg1 $3 \mathrm{~s} \quad \mathrm{Neg} 2$

'Não é ele que vai escrevê-la?'

Portanto, a partir da observação dos exemplos (25c, 25d, 25e, 25f, 25g, 25h), podemos afirmar que a interrogação, em lembaama, se faz de duas maneira:

a) por uma palavra interrogativa (cf. exemplo (25g));

b) pelo alongamento da vogal final da última palavra da sentença, seja ela qual for (Cf. exemplos (25c, 25d, 25e, 25h).

Como podemos ver, em geral, o índice do objeto ocorre depois do verbo tanto nas orações afirmativas como nas orações interrogativas. Observamos que a interrogação feita sem palavra interrogativa, isto é, pela entoação, é sempre acompanhada pelo foco, ou seja, é a interrogação pela entoação que provoca o foco e o consequente alongamento da vogal final. $\mathrm{O}$ elemento focalizado nos exemplos acima sempre aparece no final da oração. Esse elemento pode ser um verbo (Cf. exemplo (25d)), um IO (cf. exemplos (25c) ou uma negação (25h). 


\section{O Radical}

O radical, ou raiz, é o "constituinte da palavra que contém o significado lexical e não inclui afixos de flexão, mas pode incluir afixos derivacionais" (XAVIER; MATEUS, 1992, p. $321)$.

Em nossa análise, distinguimos radical de raiz. Para nós, raiz não inclui a extensão (afixos derivacionais), enquanto o radical inclui a extensão. Temos, por exemplo, as seguintes formas verbais em lembaama:

(26a). odzra 'verter/jogar' onde a raiz é -dzr-

(26b). odzrira 'estar vertido/jogado' em que o radical é -dzrir- (com a inclusão da extensão):

\begin{tabular}{|c|c|c|}
\hline 0 & $-d 3 r-$ & $-i \gamma-$ \\
\hline 12 & raiz & extensão \\
\hline
\end{tabular}

A maioria dos radicais tem a forma $\mathrm{CVC}$, em que $\mathrm{C}_{2}$ pode ser uma consoante prénasalizada: algumas das raízes têm a forma $\mathrm{CV}$, incluindo verbos comuns como - (y) VC-VC ou - CVC- CV. Segundo Nurse (2008), a maioria dessas raízes já deve ter sido um radical, ou seja, raiz seguida de extensões, embora estas últimas sejam semanticamente opacas hoje.

Quase todas as línguas bantas do leste e do sudeste da África têm verbos com uma reduplicação parcial da vogal da raiz que têm um significado lexical. Este é um dos fatos que diferenciam essas línguas (do leste e do sudeste da África) das línguas bantas do noroeste da África. Essas línguas não apresentam esse fenômeno de reduplicação que seria mais uma herança do protobanto. Por exemplo, no protobanto temos: *-pat- 'segurar', mas *-pa-pat'tocar, mover-se às cegas'. Vejamos alguns exemplos de reduplicação em verbos com raízes do tipo -C- em duas línguas faladas em Moçambique (NGUNGA, 2004):
(27a) ronga $(\mathrm{S} 54)$
-detetel-a 'comer repetidamente'
-tetetel-a 'vir repetidamente'
(27b) yao (P21)
-swaaswaaswa 'entardecer muitas vezes'
-vaavaava 'ser/estar muitas vezes' 
Segundo o autor, na língua ronga, por exemplo, a reduplicação de radicais do tipo -Climita-se apenas ao aspecto semântico, uma vez que esta língua faz uso de dispositivo morfológico que não comporta nada de reduplicação. Trata-se da extensão frequentativa. Em yao, vê-se que a base é repetida duas vezes, o que não acontece com reduplicação de radicais longos (NGUNGA, 2004, p. 190-1).

\subsection{O Radical em lembaama}

\subsubsection{Raizes não derivados}

Lembaama apresenta consoantes pré-nasalizadas, palatalizadas e labializadas (cf. quadros fonético e fonológico das consoantes acima).

a) -tipo -C- (-C-; -NC-; - $\mathbf{C}^{\left.\mathbf{W}_{-}\right)}$: esse tipo de raizes é constituído por consoantes simples, africadas, pré-nasalizadas, palatalizadas e labializadas.

(28) Exemplos: -k- 'ficar'; -t $\int$ - 'dormir'; -mp- 'dar'; -dz j - 'amar' ; -t s w - 'morder';

b) -tipo -CC-: esse tipo de raiz pode ter uma sequência de duas consoantes, sendo que a primeira pode ser uma labial ou labializada.

(29) Exemplos: -br- 'arrancar'; -kw $\mathbf{w}-$ 'enganar'; -k $\mathbf{k}^{\mathbf{w}} \mathbf{l}-$ 'dar luz';

c) -tipo -CVC-: esse tipo é constituido pela sequência consoante, vogal, consoante. Sendo que a vogal pode ser alongada.

(30) Exemplos: -man- 'acabar'; -jay- 'pegar'; -lع́r- 'colocar'; -láás- 'vestir'

d) -tipo -CVCVC- : esse tipo é constituido pela sequência consoante, vogal, consoante, vogal, consoante. Sendo que a primeira consoante pode ser uma africada.

(31) Exemplos: -kúmun- 'derrubar' ; -núrur- 'cheirar' ; -tsìnìn- 'empurrar'

Na maioria das línguas bantas, as raizes dos verbos têm frequentemente a estrutura CVC (cf. exemplo 30 acima).

\section{A Extensão}

Temos duas denominações para esta posição: a de Meeussen (1959) e a de Nurse (2008). Para Meeussen trata-se de um sufixo, enquanto Nurse (2008, p. 37) e outros bantuístas substituíram o termo sufixo por extensão. Mas essa substituição não chega a ser tão rígida, já 
que há um pequeno número de morfemas que aparecem nessa posição sem ser tão produtivos quanto os verdadeiros sufixos derivativos ou extensões. A maioria das extensões expressa categorias derivacionais de mudança de valência. Segundo Schadeberg (2003a), as extensões mais comuns são: o aplicativo (também chamado dativo, preposicional), o causativo, o extensivo, o impositivo, o passivo, o posicional (estático, estativo), o recíproco (associativo), o separativo (reversivo), o estativo (também chamado de intransitivo ou neutro), e o tentivo (contactivo). Muitas dessas extensões podem ocorrer simultaneamente. Quando isso acontece, elas tendem a fazê-lo respeitando uma certa ordem canônica (neutra) (por exemplo: 'CARP' = causativo, aplicativo, recíproco, passivo (HYMAN, 2002)). Essa ordem pode variar dependendo da sintaxe, do significado e das restrições da língua. A maioria das extensões tem tom baixo. Entretanto, elas são afetadas pelo processo que propaga o tom alto da final que as segue à sua esquerda dentro da extensão.

\subsection{A Extensão em lembaama}

Em lembaama chamamos de extensões os sufixos derivativos que ocorrem depois da raiz do verbo e antes da vogal final, e que alteram a valência do verbo. Vejam alguns exemplos de extensões aplicativas:

(32) Pessoa

nd 'á bééré mwáná

ndé á bé- ér- é mu- áná

3sg IS bater- TA- VF 1- criança

'Ele(a) bate na criança'

\section{(33) Objeto}

nd'á béréré ngómo

ndé á bé- rér- $\varepsilon$ ø- gómo

$3 \mathrm{sg}$ IS bater- TA- VF 7- tambor

'Ele bate o tambor' 
No exemplo (33) trata-se de uma extensão que só se usa quando se trata de tocar um instrumento, o tambor, no caso. Enquanto no exemplo (32) essa forma verbal pode ser usada quando se trata de bater em uma pessoa (cf. capítulo IV).

\section{A Pré-final}

Nurse (2008, p. 37) afirma que esta é a posição do morfema -ag- (que tem como variante regional -ang-) de comportamento ambíguo, porque expressa 'o imperfectivo, o repetitivo e o habitual'. Em algumas línguas, esse morfema ocupa a posição de uma extensão, em outras ele aparece antes da vogal final que é uma vogal flexional. Em outras ainda, o morfema -ag- convive nas duas posições e assume os dois papéis, como se observa no exemplo abaixo:

(34) bena (G63)

ndi- laa- gul- ang- ag- a 1s- FUT- Comprar Ext. Pré-f. VF

'Eu estarei comprando em quantidades'

Nesse exemplo, podemos ver que o morfema -ag- e sua variante -ang- ocupam as posições da extensão (-ang-) que significa 'em quantidades' e da pré-final (-ag-) que expressa o aspecto 'imperfectivo' (estar + gerúndio).

Em lembaama, o lugar da pré-final é ocupado pela extensão (cf. extensão acima). Não há distinção entre a posição da extensão e da pré-final como em bena (G63).

\section{A Final ou Vogal Final}

Um pequeno número restrito de morfemas ocorre na posição final do verbo nas línguas bantas. Tais morfemas são sempre vogais. Entre os mais frequentes estão: a vogal - $\boldsymbol{a}$ que é neutra; as vogais finais $-I$ e $-e$ que indicam o modo subjuntivo (essas vogais em geral têm tom alto); -ile passado anterior; $-a(n) g-a$ imperfectivo. Outros são menos comuns: -I anterior / passado próximo/estativo; -I negação; e o morfema envolvendo uma cópia da vogal da raiz. Todos esses morfemas finais expressam o aspecto e o modo do verbo no protobanto. O Indicativo/Neutro - $a$ é considerado não-marcado ou neutro, os outros são considerados 
marcados. Vejamos alguns exemplos citados por Nurse (2008:38), e que apresentam todas as categorias que a vogal final pode expressar nas línguas bantas :

(35a). tumbuka (N 21) - A vogal final expressa o aspecto perfectivo

t(i)-a-timb-a

ti- a- timb- a

1p P1 grudar PFTV

'Nós grudamos' (hoje)

(35b). tumbuka (N 21) - A vogal final expressa o modo subjuntivo

ti- (ka) -tol -e

$1 \mathrm{p} \quad$ (Itivo) pegar SBJ

'Nós vamos (ir e) pegar'

(35c). tumbuka (N 21) - A vogal final expressa o aspecto imperfectivo

t(i)-a-timb-anga

ti- a- timb- Anga

1p P1 atacar IPFV

'Nós estavamos atacando (hoje)'

(36) vunjo (E62) - A vogal final expressa o passado anterior

ngí-ø-wóny-1́

ngi- $\quad \varnothing-\quad \mathrm{m}-\quad$ bom- ie $\left(-i e<*_{-}\right.$-ile $)$

1s nulo IO3s ver $\quad$ ANT

'Eu vejo ela'/‘Eu tenho visto ela'

(37) venda (S20) - A vogal final expressa a negação

a- ri- $\varnothing-\quad$ rém- $\quad 1$

NEG 1p nulo cortar NEG

'Nós não cortamos'/ 'Nós não estamos cortando' 
(38) ngombe (C41) - A vogal final expressa o modo subjuntivo

Na- $\quad \varnothing-\quad$ sómb- é

1s nulo comprar SBJ

'Deixe-me comprar'

10.1 A vogal final em lembaama

Em lembaama, a vogal final varia de acordo com o Tempo, o Aspecto e o Modo (TAM). Nesse sentido, ela pode diferenciar, por exemplo, o infinitivo do aspecto perfectivo. Meeussen, A. E. (1967, p. 94), reconstruindo o banto comum, quando trata da derivação nominal, afirma que algumas reconstruções terminam em -a e significam 'ação': 'Some reconstructions point to stems in $-a$..., with the meaning "action"'. De fato, diferente do substantivo, sendo o verbo a ação por excelência, nas línguas bantas a maioria dos verbos terminam em -a no infinitivo. Essa opinião é também confirmada por D. Creissels (2004b) no seu estudo sobre o infinitivo da língua tsuana.

Quanto ao lembaama, os verbos mbaama terminam em -a, - $\boldsymbol{\varepsilon},-\boldsymbol{\jmath}$ e -i. Vejamos alguns exemplos de infinitivos:

(39a).

odzá

o- dz- á

12 (Inf) comer VF

'comer'

(39b).

odzé

o- $d z-\varepsilon$

12 ir VF

'ir' 
(39c).

otó

o- t- ó

12 chegar VF

'chegar'

(39d).

olí

o- 1- í

12 estar VF

'estar' ${ }^{24}$,

Em lembaama, a vogal final diferencia também os aspectos perfectivo e imperfectivo.

Vejamos estes exemplos:

(40). Aspecto imperfectivo

baáná má dzá biila

ba- áná má $\varnothing-\quad$ dz- á $\quad$ - biila

2 criança IS2 zero comer VF 4 comida

'As crianças comem / estão comendo comida'

(41). Aspecto perfectivo

baáná á dzí biila

ba- áná á $\varnothing-\quad$ dz- $\quad$ í $\quad$ ø- bila

2- criança IS2 zero comer- VF 4- comida

'As crianças comeram comida'

Como podemos ver, a vogal final (VF) nos exemplos acima indica o TAM (tempo, aspecto e modo), o -a em (39a) indica o infinitivo e o -i em (41) indica o aspecto perfectivo.

\footnotetext{
${ }^{24}$ As línguas bantas têm muitos verbos que podem ser traduzidos por 'estar' que representa um estado temporário. Os mais frequentes são -li e -ri ‘estar em/num lugar particular’ (Nurse, 2008:98).
} 
Por outro lado, devemos respeitar certas correlações entre morfemas para expressar certos aspectos. Por exemplo, para expressarmos o imperfectivo em lembaama, na terceira pessoa do plural, há uma correlação entre morfemas zero na raiz verbal e comutação de vogais finais (cf. exemplos (40)).

\section{A Pós-final}

O morfema mais frequente nesta posição nas línguas bantas é *-ni. Ele ocorre em todas as zonas exceto na zona $\mathrm{F}$, onde as línguas têm a final -I. Apresenta as seguintes formas alternativas -(V)ni, -Vnu e Vna, onde a Vogal Final tem geralmente um tom alto e está ligada às formas pronominais na segunda pessoa do plural. Este morfema é glosado por Meeussen como 'plural imperativo' e por Guthrie como 'um sufixo plural' nas interjeições'. Embora ocorra na maioria das vezes na segunda pessoa do plural nos imperativos, esse não é o seu único uso; ele ocorre também na primeira pessoa do plural e está presente, em algumas línguas, para todos os plurais e nos modos não-imperativos e que desempenham um papel na distinção entre o dual e o plural. Vejamos os seguintes exemplos no imperativo, no dual e no plural em LBs:

(42a). bemba (M42)

bomb- $a$ 'trabalhe' (singular)

bomb-eni 'trabalhem' (plural): aqui ele marca a segunda pessoa do plural do imperativo.

(42b). lamba (M54)

$$
\begin{aligned}
& k a-u m-y-a \text { 'ir' ( dual ) } \\
& k a-m u-y-e: n i \text { 'ir' ( plural ) }
\end{aligned}
$$

(42c). benga (A34)

$$
\begin{aligned}
& \text { kal-aka 'falar' ( dual ) } \\
& \text { kal-aka-ni 'falar' (plural) } \\
& \text { ho-kala-ni, ho-kal-aka-ni 'Vamos falar' (imperativo) }
\end{aligned}
$$

(42d). nkoya (L62)

$$
\begin{aligned}
& \text { mona 'ver, olhar' (singular) } \\
& \text { mon-enu 'ver, olhar' (plural) }
\end{aligned}
$$


Nas línguas contemporâneas, outros morfemas e categorias podem ocorrer na pósinicial, porque, assim como para a pré-inicial, as posições ao redor do verbo tendem a atrair um novo material recentemente gramaticalizado. Essas novas categorias incluem locativos, pronomes objetos, foco, aspecto e tempo. Assim, em benga (A34), o morfema -ngo que aparentemente expressa o imperfectivo ocorre na pós-final:

(43) benga (A34)

mbikalango

mbi- ka- a- ngo

1s Falar VF IPFV

'Eu estou/estava falando'

Ao menos duas dessas categorias adotadas por algumas línguas hoje, como pronomes objetos e clíticos, começaram na língua, sem dúvida, como elementos pós-verbais independentes que foram atraídos pelo verbo no decorrer dos tempos. O estatuto contemporâneo desses morfemas como elementos independentes, como clíticos ou sufixos nem sempre é claro.

\subsection{A Pós-final em lembaama}

Em lembaama, depois da VF, portanto, na pós-final, dependendo da sentença, podemos ter um objeto ou o índice do objeto. Por exemplo:

(44) O índice do objeto (IO)

bááná má dzábiila || bó má dzá dzó

bá- áná má- dz- á ø- biila bó má- dz- á dzó

2- criança IS2 comer VF comida $3 p$ Pres comer VF IO

'As crianças comem/vão comer a comida. Eles comem-na/ vão comê-la'

Podemos também ter o segundo elemento da negação: o morfema ní. Por exemplo: 
(45a)

bááná má ka dzábiila ní.

bá- áná má- ka dz- á ø- biila ní

2- criança IS2 Neg comer VF comida Neg

'As crianças não comem/ não vão comer a comida.

bó má ka dzá dzó ní

bó má- ka dz- á dzó ní

3p Pres Neg comer VF IO Neg

Eles não comem-na/ não vão comê-la'

A negação é composta por duas marcas: $k a . . . n i$. Um morfema descontínuo, como foi dito acima. A segunda marca (-ni) é a única que vem depois da VF.

Em síntese, da estrutura verbal oriunda do protobanto, que é geral e comum a todas as línguas bantas (cf. Meeussen, (1959) e Nurse (2008), o lembaama herdou e conservou as seguintes posições e seus elementos:

1. A pré-inicial, que pode ser um relativo;

2. A inicial, que pode ser um sujeito e/ou um índice do sujeito que nunca aparece no imperativo singular;

3. A pós-inicial, que pode ser a primeira parte da negação $(k a-\ldots . .$.$) ;$

4. O formativo, que representa, em geral, o morfema de tempo. Ele pode, por exemplo, distinguir o passado recente ( $\left.m i^{-}\right)$do passado distante ( $\left.m a ́-\right)$ por exemplo;

6. O infixo que pode ser o índice do objeto (IO) e que é um morfema independente;

7. O radical, que é um elemento obrigatório por ser constituído pela raiz do verbo e por uma extensão (às vezes), é uma posição sempre preenchida;

8. A extensão, que representa os sufixos derivativos. Não é uma posição sempre preenchida, já que os sufixos derivativos são poucos (têm um número limitado em cada língua banta);

10. A final, que é a vogal final. Ela é obrigatória, já que ela indica o aspecto (o perfectivo ou imperfectivo);

11. A pós-final onde só cabe o objeto ou o índice do objeto e a segunda parte da negação $(\ldots . .-n i)$. 
Em lembaama só falta a posição 5, o limitativo.

A saturação máxima da estrutura verbal em lembaama tem os seguintes elementos: $($ um sujeito $)+$ um índice do sujeito $+(N e g)+$ uma marca de tempo + Raiz do verbo + (uma extensão) + uma vogal final + (objetos ou um índice do objeto $)+(\mathrm{Neg})$.

Vale lembrar que os elementos acima se seguem tanto no verbo como na oração numa ordem fixa. As posições entre parênteses não são obrigatórios. Vejamos um exemplo:

bááná má kajisir’ákwúrúmbjaní

ba- áná má ka ø- ji-sir- a a- kwúrú mbija ní 2 crianças IS Neg zero ensinar-Ext.Ben- VF 2 velhos caça Neg $\begin{array}{llllllllll}\text { Sujeito } & \text { IS } & \text { Neg } & \text { MT } & \text { Radical do verbo } & \text { VF } & 2 & \text { O1 } & \text { O2 } & \text { Neg }\end{array}$ ' crianças não ensinam/ não vão ensinar a caça aos velhos'

Apresentamos a seguir uma descrição sintática de cada elemento da estrutura verbal do lembaama:

a) O sujeito

Qualquer substantivo ou pronome pode assumir a função de sujeito, que aparece no primeiro lugar da estrutura. Os substantivos do lembaama são classificados por prefixos. Os prefixos por sua vez são classificados em classes. Cada nome ou substantivo pertence a uma das 12 classes nominais do lembaama (Okoudowa, 2005:29). Vejamos estes exemplos de orações com pronome sujeito e com sujeito lexical:

(47). Com sujeito lexical

mwán’álila

mu- áná a $\varnothing \quad$-lil- a

1- criança IS1 Pres chorar VF

'A criança chora' 
(48). Com pronome sujeito

nd’álila

ndé a $\varnothing \quad-1 i l-\quad a$

3s IS1 Pres Chorar VF

'Ele(a) chora'

b) O índice do sujeito

É obrigatório em todas as formas verbais flexionadas. Salvo no imperativo singular que é um modo que geralmente não admite um sujeito explicito (cf. modo imperativo no capítulo V). Trata-se de um morfema que retoma o sujeito, com quem concorda em classe. Ocupa o primeiro lugar no verbo propriamente dito (excluindo o sujeito do verbo).

Nas orações acima o índice de sujeito dos sujeitos mwana e ndé é a.

Vejamos este exemplo no imperativo com o IS sem o sujeito:

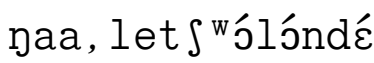

naa le- tswól- j́ ndé

Então IS1p chamar VF $3 s$

'Então, vamos chamá-lo(a)'

Os pronomes pessoais do lembaama, apresentam-se da maneira seguinte, com seus respectivos índices do sujeito (os mais usados estão em negrito): 
Quadro 6: Pronomes pessoais do lembaama

\begin{tabular}{|c|c|c|c|}
\hline \multicolumn{4}{|l|}{ Singular } \\
\hline Pessoas & Pronomes & Índice do sujeito & Tradução \\
\hline $1^{\mathrm{a}}$ & $\mathrm{m} \varepsilon \dot{\varepsilon}$ & e & $\mathrm{eu}$ \\
\hline $2^{\mathrm{a}}$ & wé & $0, a$ & você \\
\hline $3^{\mathrm{a}}$ & ndé & $0, a$ & ele/ela \\
\hline \multicolumn{4}{|l|}{ Plural } \\
\hline $1^{\mathrm{a}}-\mathrm{a}$ & bsí, sáá-bo & le & Nós exclusivo $^{25}$ (eu e eles/elas) \\
\hline$-b$ & sáá- we & le & Nós inclusivo (eu e você) \\
\hline$-\mathrm{c}$ & sáá-ndé & le & Nós exclusivo (eu e ele/ela) \\
\hline$-d$ & sáá-bé & le & Nós inclusivo (eu e vocês) \\
\hline $2^{\mathrm{a}}$ & bُ & le & vocês \\
\hline $3^{\mathrm{a}}$ & bó & $a, \mathrm{ma}$ & Eles/elas \\
\hline
\end{tabular}

Alguns pronomes podem ter mais de um índice do sujeito já que ele pode variar em tempo e aspecto. É o caso das duas últimas pessoas do singular (segunda e terceira) e da terceira pessoa do plural. O índice o é usado com o passado e o aspecto perfectivo. Enquanto o índice a é usado com o presente/futuro e o aspecto imperfectivo. Resumindo, o índice da esquerda é usado com o passado e o aspecto perfectivo. O da direita é usado com o presente/futuro e o aspecto imperfectivo.

c) A negação

Em lembaama, como já foi dito, a negação de qualquer forma verbal flexionada é formada por um morfema descontínuo com dois elementos: ka...ní. O primeiro é o morfema, $\boldsymbol{k} \boldsymbol{a} . .$. (de tom baixo), que vem sempre entre o índice do sujeito e o radical do verbo. A última parte desse morfema, ...ní (de tom alto), vem sempre no final do verbo, depois da vogal final.

${ }^{25}$ Exclusivo e inclusivo, sempre com relação ao interlocutor: exclui ou inclui. Em negrito, estão as formas mais usadas. 
(50)

mwán ’á kalilaní

mu- áná á ka- $\varnothing$-lil- a

1- criança IS1 Neg chorar VF Neg

'A criança não chora/não vai chorar'

nd'á kadzananza blá wení

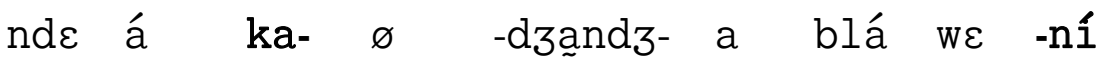

3s IS2s Neg MT trabalha VF com 2s Neg

'Ele(a) não trabalha/não vai trabalhar contigo'

d) A marca de tempo

Aparece sempre à esquerda do radical do verbo entre o índice do sujeito e o radical (para uma oração afirmativa) ou entre a primeira parte da negação e o radical do verbo em sentenças negativas. Nos exemplos acima, o tempo é marcado pelo morfema zero ( $\varnothing)$. Tratase de um tempo que é concomitante ao momento da enunciação. Se usarmos um desses enunciados no passado, teremos um índice do sujeito diferente e uma marca do passado.

mwán ’ómílila

mu- áná o mí -lil- a

1- criança IS1 P1 chorar VF

'A criança chorou'

Como podemos observar, nesse exemplo, o passado é marcado pelo morfema mí- que é anteposto ao radical verbal. Comparando com o exemplo 47 acima, vemos que além do índice do sujeito (que mudou de a no presente para o no passado), a marca de tempo, também mudou (de zero no presente, para mí-, com tom alto, no passado). Dessa maneira, cada índice 
do sujeito é usado de acordo com seu devido tempo. O morfema mí- marca o passado recente (P1). Ele indica uma ação que acabou de se realizar há pouco tempo (cf. Capítulo V).

e) A raiz e o radical do verbo

Trata-se do verbo na sua forma mais simples: é o verbo desprovido de seus afixos e infixos, mas que possui o significado deste. Por exemplo, temos o verbo odzá 'comer'. Nessa forma verbal, o o- é o prefixo verbal marcador do infinitivo. O -dz- é a raiz (por ser um verbo sem extensão) e o -a é a vogal final. Caso tenhamos um verbo que apresente uma extensão, teremos uma situação diferente:

odzra

$0 \quad-d z r-a$

12 Raiz VF

'Verter'

odzrira

o - d3r- ir- a

12 Raiz Ext VF

'Verter-se'

No exemplo 53, temos um verbo sem extensão. A raiz ou o radical dele é $-d z r-$ 'verter'. No exemplo 54 pelo contrário, temos a mesma raiz e a extensão reversiva representada pelo morfema derivativo -ig-. Nesse caso, o radical é -dzrig- 'verter-se'. Ou seja, o radical inclui a extensão. 
f) A extensão

Trata-se de um morfema derivativo, que aparece entre a raiz do verbo e a vogal final deste, para lhe mudar o sentido. Assim, a raiz e a extensão formam o radical de um verbo (que tem uma extensão). (cf. Capítulo IV).

g) A vogal final

Trata-se da última vogal do verbo como o seu próprio nome diz. Em um verbo flexionado, ela indica essencialmente o aspecto. $\mathrm{O}$ aspecto é geralmente posposto ao radical do verbo em lembaama. Vejamos este exemplo:

mwán’álîlí

mu- áná á -lil- í

1- criança IS1 chorar VF

'A criança chorou'

Se comparado ao exemplo 52 (acima), podemos observar que em 55, a vogal final e o IS mudaram. Embora o significado da oração seja o mesmo "a criança chorou", neste, consideramos o aspecto como acabado; não o tempo (marcado à esquerda do radical). Esse aspecto é marcado pela vogal final -í (à direita do radical) que geralmente tem um tom alto. Exceto no habitual passado.

h) $O(s)$ objeto(s)

Trata-se de todo nome ou pronome que estabelece uma relação transitiva com o verbo. O objeto é geralmente posposto ao radical e aparece depois da vogal final. 
(56a).

mwán ’ómîlilángúrú

mu- áná ó mí -lil- a ø-ygúru

1- criança IS1 P1 chorar VF 1-mãe

'Literalmente: A criança chorou a mãe (A criança chorou pela ausência da mãe)'

(56b).

mwán’ómîlilándé

mu- áná ó mí -lil- a ndé

1- criança IS1 P1 chorar VF $3 \mathrm{~s}$

'A criança a(o) chorou'

Mas o objeto também pode ser anteposto ao verbo. Principalmente em uma oração interrogativa com ênfase.

$(56 c)$

mwáná, ngúr’álilaa

mu- áná ø ø-ngúrú a -lil- a

1- criança MT 1-mãe IS1 chorar VF

'A criança chora/está chorando/vai chorar a mãe ?' ou

'É a mãe que a criança chora/ está chorando/vai chorar ?

Neste exemplo, o objeto é 'a mãe', que é enfatizado, por isso antecede o verbo.

\section{Conclusão}

Por todas essas razões, a estrutura verbal lembaama se diferencia do protobanto pelas seguintes características:

i) Lembaama não aceita a 'inversão locativa' nem a posição: o limitativo;

ii) aceita infinitivo com as seguintes vogais finais: $\boldsymbol{\jmath}, \boldsymbol{\varepsilon}$ além de a $e \mathbf{i}$; 
iii) não distingue a posição sufixo ou extensão da pré-final;

iv) a negação de qualquer forma verbal flexionada é formada pelo morfema descontinuo ka...ní;

v) o IO é posposto ao verbo. Trata-se, como já foi dito, de um pronome independente.

Creissels (1991, p. 293) ao estudar as 'formas verbais simples' do tsuana (S31), apresenta a estrutura do verbo banto como uma sequência de 8 posições, das quais três são necessariamente fornecidas (as que não estão entre parênteses):

(1) 2 (3) (4) (5) 6 (7) 8

Essas posições não mudam de nome nem de função com Creissels (cf. descrição acima). Ele só destaca algumas funções. Assim, segundo ele, a posição 6 é a do elemento lexical irredutível (o radical). A posição 2 é a do índice de sujeito (obrigatoriamente presente em tsuana). A posição 5 é aquela que ocupa um morfema -i(N)- usualmente designado como reflexivo (para o tsuana). A posição 7 é a dos morfemas chamados 'extensões verbais' nas línguas bantas. São possíveis associações de vários morfemas deste tipo. Vejamos alguns exemplos do tsuana (S31) dados por Creissels (Op. Cit., p. 294):

$$
\begin{aligned}
& \text { tsuana (S31) ki- rék- a lo bonc 'Eu compro uma lâmpada' } \\
& \begin{array}{lll}
2 & 6 & 8
\end{array} \\
& \text { 1s comprar VF } 11 \text { lâmpada (glosa acrescentada) } \\
& \text { tsuana (S31) ki- a- ló- rék- a 'Eu compro-a' } \\
& \begin{array}{lllll}
2 & 3 & 4 & 6 & 8
\end{array} \\
& \text { 1s Pres IO comprar VF (glosa acrescentada) }
\end{aligned}
$$

Ainda, segundo o autor, a descrição das posições 1, 3 e 8 coloca um problema particular: se é possível ter uma independência relativa entre as outras posições cuja sequência define a palavra verbal, o mesmo não se pode dizer para as posições 1, 3 e 8; há tantas obrigações mútuas que não dá para analisá-las isoladamente: de fato, num enunciado contendo um verbo flexionado numa língua banta, o verbo está interligado ao sujeito, ao objeto e a todos os índices ou marcas pela concordância em número. No verbo encontramos vários elementos fundamentais que determinam o sentido do enunciado, pelo menos numa descrição sincrônica (só a posição 8 ou final está necessariamente presente), ela predomina 
globalmente, pois é ela que determina o significado da forma verbal do ponto de vista do aspecto, do modo e da negação.

O linguista moçambicano Armindo Ngunga (2004, p. 149), num estudo sobre línguas bantas, apresenta a estrutura do verbo banto de forma hierárquica:

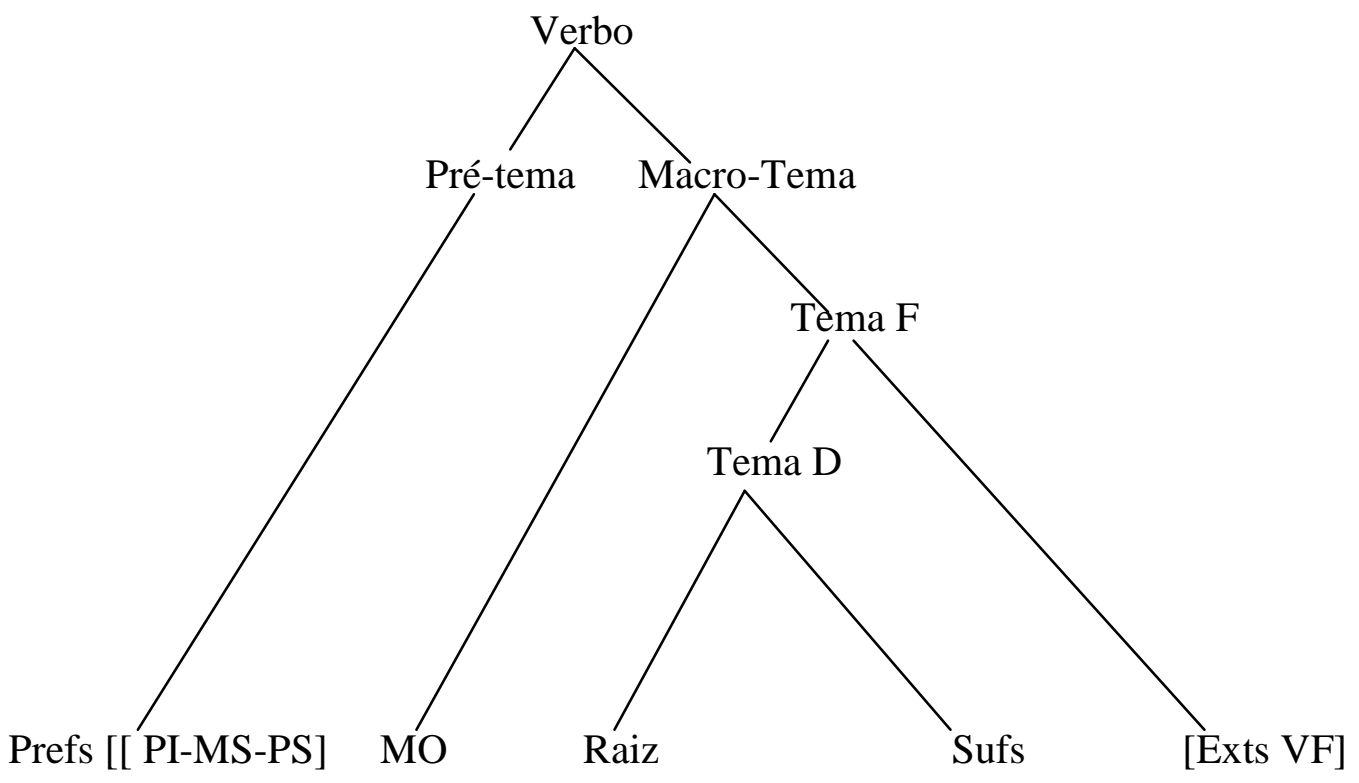

Onde Tema F: Tema Flexionado; Tema D: Tema derivado; MS: Marca de sujeto ou índice sujeito (para outros estudiosos); PS: pós-sujeito; PI: Pré-inicial; MO: Marca de Objeto; Exts: Extensões (verbais); VF: Vogal final, também chamada Vogal Terminal (VT).

Para o mesmo autor, esta estrutura pode adaptar-se a qualquer língua banta, mas não é obrigatório que toda a língua banta tenha todos os elementos aqui apresentados. Por exemplo, nas línguas em que existam, a PI é geralmente marca de negação, e o PS marca de tempo, às vezes pode ser sufixo e ocorrer depois da raiz. Quando presente, a MO é o único morfema cuja posição é fixa na estrutura da forma verbal, ocorrendo imediatamente antes da raiz. É por isso que o macro-tema inclui a MO e o tema flexionado (NGUNGA, 2004, p. 149).

Os esquemas elaborados por todos esses autores bantuístas (Meeussen, Nurse, Creissels e Ngunga) demonstram seus esforços analíticos para explicar a complexidade da estrutura dos verbos nas línguas bantas. A representação hierárquica de Ngunga é importante por ser uma síntese de todas as outras e, principalmente, por mostrar a hierarquia e a ordem dos elementos que têm um papel muito importante: é na raiz verbal que se concentram todos os outros elementos fundamentais que determinam o sentido do enunciado, fazem a concordância, criam outros significados, expressam o tempo, o aspecto, o modo e a negação em qualquer língua banta. 


\section{Capítulo IV - A DERIVAÇÃO VERBAL}

\section{Introdução}

Entendemos por derivação verbal o acréscimo de um morfema ou sufixo entre o radical e a vogal final de um verbo banto, que resulta na formação de uma forma verbal derivada com outro significado. Os derivativos correspondem ao que os linguistas bantuístas chamam de extensões verbais. O número, o tipo e a forma dessas extensões verbais variam de uma língua para outra. Em geral, sua estrutura fonológica é do tipo -V- ou -VC-.

Dependendo da língua, podemos ter as seguintes extensões: benefactiva, causativa, aplicativa, passiva, intensiva, estativa, frequentativa, reversiva, recíproca, impositiva, neutra, transitiva, intransitiva, etc.

Os morfemas derivativos expressam e reforçam a transitividade atuando sobre a relação entre os participantes de uma ação. As extensões trazem algo novo para a forma inicial do verbo e consequentemente para a oração, seja no plano semântico como no plano sintático.

A questão dos sufixos derivativos envolve a transitividade em lembaama porque o acréscimo ou a mudança de um sufixo derivativo em um verbo pode fazer com que o verbo seja ou deixe de ser transitivo. Para compreender este fato em lembaama, apoiamo-nos em Hopper e Thompson (1980, p. 251-299). Retomamos na sequência, sua proposta sobre a transitividade.

\section{A Transitividade segundo Hopper e Thompson (1980:251-299)}

Os autores reconhecem que a transitividade é uma relação fundamental nas línguas naturais, tendo em vista o papel importante que ela desempenha na gramática e no discurso. Hopper e Thompson definem a transitividade, primeiramente, de acordo com a tradição: uma atividade realizada ou transferida de um agente para um paciente, que envolve, portanto, pelo menos dois participantes.

Para os autores, a transitividade é um continuum. Como primeiro passo, eles propõem isolar as partes que compõem a noção de transitividade e estudar a maneira como são tipicamente representados pelas línguas do mundo. O que nos interessa nessa proposta são os seguintes critérios que os autores elaboraram para distinguir a transitividade baixa da alta: 
Quadro 7: Critérios da transitividade segundo Hopper e Thompson (1980:252)

\begin{tabular}{|l|l|l|}
\hline & ALTA & BAIXA \\
\hline A. PARTICIPANTES & 2 ou mais participantes, A e O ${ }^{26}$ & 1 participante \\
\hline B. CINESE & ação & não-ação \\
\hline C. ASPECTO & télico & atélico \\
\hline D. PONTUAL IDADE & pontual & não-pontual \\
\hline E. VOLICIONALIDADE & volicional & não-volicional \\
\hline F. AFIRMAÇÃO & afirmativo & negativo \\
\hline G. MODO & real & irreal \\
\hline H. AGENTIVIDADE & Organização alta em potência (forte) & baixa em potência (fraca) \\
\hline I. AFETAÇÃO & O totalmente afetado & O não-afetado \\
\hline J. INDIVIDUAÇÃO & O altamente particularizado & O não-particularizado \\
\hline
\end{tabular}

É fácil mostrar que cada componente da transitividade envolve uma afetação ou uma intensidade com a qual a ação é transferida de um participante para outro:

(A) PARTICIPANTES: nenhuma transferência pode acontecer sem que haja pelo menos dois participantes envolvidos.

(B) CINESE: uma ação pode ser transferida de um participante para o outro; estados não podem. Assim algo acontece com Sally em Eu abraço Sally, mas não em Eu amo Sally.

(C) ASPECTO: uma ação vista a partir do seu ponto de vista. Isto é, uma ação télica é mais efetivamente transferida para um paciente do que uma que não é télica (completa ou acabada) com um final semelhante. Numa oração télica como comi tudo, a atividade é vista como completa, a ação é realizada inteiramente e por isso tem uma alta transitividade; mas numa oração não-télica como estou comendo isto, a ação não está acabada e por isso tem uma baixa transitividade.

(D) PONTUALIDADE: as ações realizadas sem nenhuma fase de transição evidente entre o seu início e o seu fim têm um efeito mais marcado nos seus pacientes do que ações em andamento; há, por exemplo, um contraste entre os verbos kick 'chutar' (pontual) e carry 'carregar'(não-pontual).

\footnotetext{
${ }^{26}$ Os autores desta proposta seguem a nomenclatura de Dixon (1979) que usa 'A'(para Agente) e 'O' (para Objeto) para se referir aos dois participantes numa oração com dois participantes. Segundo os autores, não há problema se os argumentos referentes aos participantes referirem-se também ao verbo nas suas relações gramaticais. O termo 'paciente' se refere a um objeto que é de fato o 'receptor/destinatário' da ação numa relação transitiva fundamental.
} 
(E) VOLICIONALIDADE: o efeito no paciente é mais aparente quando o participante é apresentado como atuando propositalmente; há, por exemplo, um contraste entre Escrevi teu nome (volicional)[ação realizada pela vontade ou a intenção do sujeito] e Esqueci teu nome (não-volicional) [ação realizada sem a vontade ou a intenção do sujeito].

(F) AFIRMAÇÃO: esse é o parâmetro afirmação vs negação.

(G) O MODO: esse se refere à distinção entre real e irreal como qualidade dos acontecimentos ou eventos. Uma ação que não ocorreu ou que é apresentada como em andamento num mundo não-real (contingente) é obviamente menos efetiva, do que uma ação cuja ocorrência é confirmada num acontecimento ou num evento real.

(H) AGENTIVIDADE: participantes altos em Agência podem afetar a transferência de uma ação contrariamente àqueles que são baixos em Agência. Assim, a interpretação normal da oração George me assustou é a de um evento perceptível com consequências perceptíveis; mas a interpretação normal de A foto me assustou seria algo de um estado interno.

Finalmente, chegamos a algo que se refere ao Objeto: (I) AFETAÇÃO do Objeto e (J) INDIVIDUAÇÃO do objeto. O grau em que a ação é transferida para um paciente é uma função de como o paciente é completamente AFETADO; isso se vê de fato quando dizemos Bebi o leite de um trago, em vez de dizer, simplesmente, Bebi um pouco de leite. $\mathrm{O}$ componente da INDIVIDUAÇÃO, entretanto, se refere tanto à peculiaridade do paciente com relação aos participantes quanto à sua peculiaridade com relação a sua própria origem ou a ele mesmo. Assim os referentes dos nomes com propriedades à esquerda abaixo são mais altamente particularizados do que aqueles que estão à direita (Cf. TIMBERLAKE, 1975; 1977):

$\begin{array}{ll}\text { INDIVIDUADO } & \text { NÃO-INDIVIDUADO } \\ \text { Próprio } & \text { Comum } \\ \text { Humano, animado } & \text { Não-animado } \\ \text { Concreto } & \text { Abstrato } \\ \text { Singular } & \text { Plural } \\ \text { Contável } & \text { Não-contável } \\ \text { Referencial, definido } & \text { Não-referencial, Indefinido }\end{array}$

Uma ação pode ser mais efetivamente transferida para um paciente que é individuado do que para um que não é; assim um objeto definido é frequentemente visto como mais completamente afetado do que um indefinido. Em Fritz bebeu a cerveja, há uma possível e 
até provável implicação de que ele acabou a cerveja de que dispunha; mas em Fritz bebeu um pouco de cerveja, essa implicação é obtida com dificuldade (isto é, só se tão pouca cerveja foi deixada, fazendo com que beber pouco seja equivalente a beber toda ela). É a mesma coisa com os pacientes animados e não-animados: em choquei-me com Charles o foco de atenção é provavelmente colocado sobre o evento: o choque com Charles ou talvez nos dois participantes; mas em Eu bati (o pé) na mesa é menos provável que algo tenha acontecido com a mesa; é mais provável que o efeito do choque sobre o participante (A) seja mais ressaltado.

A transitividade é, então, vista da maneira mais convencional possível, como sendo o fato de passar de um lado para o outro ou de transferir uma ação de um participante para o outro. Pode ser analisada a partir das partes que a compõem (pelos seus participantes), cada um focalizando uma das facetas dessa transferência, numa parte diferente da oração. Quando consideradas juntas, essas partes permitem às orações serem caracterizadas como sendo mais ou menos transitivas: quanto mais a oração tiver as características de $\mathrm{A}$ até $\mathrm{J}$ da coluna à esquerda (alta transitividade), mais ela será transitiva. E mais ela estará próxima à Transitividade Cardinal. Comparemos estes exemplos:
a. Jerry gosta de cerveja
b. Jerry derrubou Sam

O exemplo 1 b acima é mais alto em transitividade do que o exemplo 1a porque mostra as seguintes características:

Cinese: Ação.

Aspecto: télico

Pontualidade: pontual.

Afetação do Objeto: total.

Individuação do Objeto: alto, referencial, animado, e próprio.

Vejamos mais um exemplo:

(2) Não havia nenhuma estrela no céu.

Esse exemplo seria muito mais baixo em transitividade do que os exemplos 1a e $1 \mathrm{~b}$ acima, já que ele não tem nenhuma característica de alta transitividade a não ser o modo real. 
A partir da aplicação desses critérios, podemos melhor entender a transitividade nos exemplos que daremos com os sufixos derivativos ou extensões verbais do lembaama.

\section{Os sufixos derivativos e a transitividade em lembaama}

Separamos os derivativos do lembaama conforme seus valores gramaticais e semânticos. Assim sendo, vamos analisar os sufixos derivativos comparando seus valores gramaticais e semânticos caso a caso. No que diz respeito às extensões transitivas, os autores Nurse e Philippson (2003, p. 77-78) assinalam que a maior parte das descrições de línguas bantas indicam duas extensões: uma transitiva *-vl- e uma intransitiva *-vk- que são reconstruções do protobanto. A língua lembaama apresenta os seguintes casos:

\section{Caso 1}

Oração transitiva 1 sem sufixo derivativo (transitividade alta).

Raíz verbal: -dzir - 'derramar'

mwán’ó mídzir’ándz’ó nt je

mu- áná o mí dzir- ø- à á- ndzá ó ø- $\operatorname{nt} \int^{j} \varepsilon$

1- criança IS1 P1 jogar TA $\quad$ VF 8 água $\quad$ Loc 7 terra

'A criança derramou a água no chão'

Oração intransitiva com sufixo derivativo /-ig-/

Radical verbal: -dzirig- 'derramar/ derramar-se/ estar derramado'

ándz’á mí dzrir’ó nt jo

á- ndzá a mí dzr- ir $-a$ ó $\varnothing-\operatorname{nt} \int^{j} \varepsilon$

8 água IS8 P1 derramar Intr VF 1 loc 7 terra

'A água está derramada no chão'

O exemplo (1a) acima é mais alto em transitividade do que o exemplo (1b) porque mostra as seguintes características: 
Participantes: dois (a criança é o agente e a água é o objeto ou o paciente)

Cinese: ação

Aspecto: télico

Pontualidade: pontual

Afetação do objeto: total

Individuação do objeto: concreto e definido.

Enquanto o exemplo (1b) tem baixa transitividade porque só tem um participante: a água. Além do mais, é uma oração intransitiva porque não tem objeto, ou seja, o seu objeto é indefinido. Logo, essa oração não responde ao critério da individuação que é uma das características mais importantes da transitividade. Esse fato está, portanto, relacionado ao baixo valor da transitividade (Cf. Critérios da transitividade baixa acima). De fato, verbos intransitivos são considerados nesta proposta como tendo uma transitividade baixa. No exemplo acima, o sufixo derivativo /-ig-/ modifica o valor gramatical do verbo, isto é, o verbo deixa de ser transitivo e se torna intransitivo.

Outro exemplo com esse sufixo derivativo é encontrado na seguinte raiz verbal: -pi ir- 'apertar' (transitivo) que tem como radical verbal:

-pirig- 'amolecer'(intransitivo).

\section{Caso 2}

Oração transitiva 2 sem sufixo derivativo (transitividade alta).

Raíz: -bul- 'quebrar'

mwán’ó mî búl’ólạ́ngu

mu- áná o mî bul- ø- á ó- la্রgu

1 criança IS1 P1 quebrar TA $\quad$ VF 3 garrafa

'A criança quebrou a garrafa'

Oração intransitiva com o sufixo derivativo /-ug-/

Radical: -bulug- 'quebrar/quebrar-se/ estar quebrado'. 
(2b)

óláng’ó mî búlura

ó- långu o mí búl- ur- a

3 garrafa IS3 P1 quebrar Intr VF

'A garrafa quebrou/ quebrou-se/ está quebrada'

O exemplo (2a) acima é mais alto em transitividade do que o exemplo (2b) porque mostra as seguintes características:

Participantes: dois (a criança é o agente e a garrafa é o objeto)

Cinese: ação

Aspecto: télico

Pontualidade: pontual

Afetação do objeto: total

Individuação do objeto: definido, concreto, contável e singular.

Enquanto o exemplo (2b) tem uma baixa transitividade porque só há um participante: a garrafa, que é um objeto individuado e definido. Aqui, também, o sufixo derivativo /-ug-/ modifica o valor gramatical do verbo, isto é, o verbo deixa de ser transitivo e se torna intransitivo.

Nos casos 1 e 2, acima, o processo é o mesmo. Há uma destituição do Agente: o participante O movimentou-se para a posição de A.

\section{Caso 3}

Oração transitiva 3 com sufixo derivativo /-is-/(transitividade alta)

Radical verbal: -bi is- 'estragar'

(3a)

$$
\begin{aligned}
& \text { mwan’ó mí bîísá ngwómí } \\
& \text { mu- áná o mí bî- î́s- á ø- ngwómí } \\
& 1 \text { criança IS1 } 1 \text { P1 estragar } \quad \text { TA } \quad \text { VF } 7 \text { rádio }
\end{aligned}
$$




\section{Oração intransitiva sem sufixo derivativo}

Raiz verbal: -bi- 'estragar/ estragar-se/ estar estragado'

$(3 b)$.

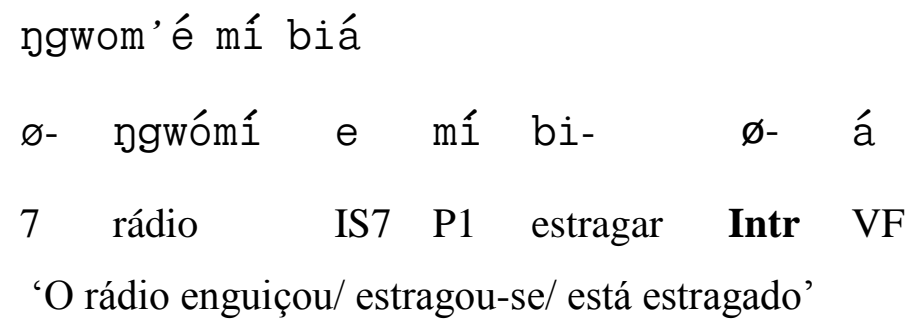

Nesse caso a oração mais transitiva é a que tem o sufixo derivativo porque mostra as seguintes características:

Participantes: dois (a criança é o agente e o radio é o objeto)

Cinese: ação

Aspecto: télico

Pontualidade: pontual

Afetação do objeto: total

Individuação do objeto: concreto, contável e singular.

Enquanto a oração (3b) é de transitividade baixa porque não há objeto, isto é, o objeto é indefinido. Observamos também a ausência do sufixo derivativo. Aqui, contrariamente ao que vimos acima, é a ausência do sufixo derivativo que muda o valor gramatical do verbo: o verbo deixa de ser transitivo e se torna intransitivo.

\section{Caso 4}

Oração transitiva 4 com sufixo derivativo /-S-/ (transitividade alta).

Radical: -dzwás- 'ferir'

$$
\begin{aligned}
& \text { mwán’ó mî dzºásá mvúr’ó kwúlú } \\
& \text { mu- áná o mí dzwá- s- á mv- úru ó ø- kúlú } \\
& 1 \text { criança IS1 P1 ferir TA VF } 1 \text { pessoa Loc pé }
\end{aligned}
$$


Oração transitiva com o sufixo derivativo /-l-/(transitividade baixa).

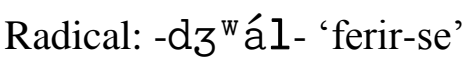

(4b).

\begin{tabular}{|c|c|c|c|c|c|c|c|c|c|}
\hline mu- & áná & 0 & mî & d3 $3^{w} a ́-$ & 1- & á & ó & $\varnothing-$ & $\mathrm{k}^{\mathrm{w}} u ́ l u ́$ \\
\hline 1 & criança & IS & $\mathrm{P} 1$ & ferir & TB & VF & Loc & & pé \\
\hline
\end{tabular}

'A criança feriu-se/ está ferida no pé'

No exemplo (4a), a transitividade é mais alta do que no exemplo (4b) porque mostra as seguintes características:

Participantes: dois (a criança é o agente e alguém é o objeto)

Cinese: ação

Aspecto: télico

Pontualidade: pontual

Afetação do objeto: total

Individuação do objeto: humano, animado, concreto, contável e singular.

Isso é diferente do exemplo (4b) que tem apenas um participante (a criança) que é ao mesmo tempo o agente e o objeto ou o paciente. Trata-se, portanto, de uma ação reflexiva. Consideramos a oração reflexiva (4b) como uma oração de transitividade baixa porque tem apenas um participante. Isso porque a transitividade alta exige a participação de, no mínimo, dois participantes.

Vejamos outros derivativos que refletem o mesmo fenômeno de transitividade alta (com dois participantes) vs transitividade baixa (com um participante):

\section{Caso 5}

Oração transitiva 5 com sufixo derivativo /- us -/ (transitividade alta)

Radical: -nuus- 'acordar' 
(5a)

loßí ngúr’á nuusá mwáná

lobí ø- ggúrú a ø- nu- us- á mu- áná

Hoje 1 mãe $\quad$ IS1 Pres Acordar- TA VF 1 filho

'Hoje a mãe (vai) acorda (r) o filho'

\section{Oração transitiva com o sufixo derivativo /-sug-/ (transitividade baixa)}

Radical verbal: -nusug- 'acordar-se/ estar acordado'

lobi mwán’á nusura nd ’ánkúlú

lobi mu- áná a ø- nu- sur- a ndé ạkúlú

Hoje 1 filho IS1 Pres Acordar- TB VF $3 \mathrm{~s}$ mesmo

'Hoje o filho acorda/ vai acordar por ele mesmo' (sozinho)

No exemplo (5a) a transitividade é mais alta do que no exemplo (5b) porque mostra as seguintes características:

Participantes: dois (a mãe é o agente e o filho é o objeto)

Cinese: ação

Aspecto: télico

Pontualidade: pontual

Afetação do objeto: total

Individuação do objeto: humano, animado, concreto, contável, definido e singular.

Isso é diferente do exemplo (5b), que tem apenas um participante (o filho), que é ao mesmo tempo o agente e o paciente.

Essas duas extensões indicam uma diferença na transitividade da ação. No exemplo (5a), o filho acorda pela ação da mãe. No exemplo (5b), o filho acorda por ele mesmo, sem a ação da mãe. Isso mostra uma autonomia ou uma independência do filho com relação à mãe. Trata-se de uma ação reflexiva. É por isso que o exemplo (5a) tem uma transitividade mais alta. O exemplo (5b) pelo fato de expressar uma ação do sujeito sobre ele mesmo tem uma 
transitividade mais baixa, porque a transitividade alta exige a participação de, no mínimo, dois participantes.

Um caso semelhante ainda é expresso pelo sufixo derivativo /-rag-/ realizado -rag-.

\section{Caso 6}

Oração transitiva 6 com sufixo derivativo /-ar-/ (transitividade alta)

Radical verbal: -saar- 'levantar'

(6a)

\begin{tabular}{|c|c|c|c|c|c|c|c|}
\hline$\varnothing-$ & taará & 0 & mí & sá- & ár- & á & mu- \\
\hline $1-$ & Pai & IS 1 & $\mathrm{P} 1$ & levantar & TA & VF & 1 \\
\hline
\end{tabular}

Oração transitiva com sufixo derivativo /-rag-/(transitividade baixa)

Radical verbal: -sarag- 'levantar-se/ estar levantado'

(6b)

\begin{tabular}{|c|c|c|c|c|c|c|}
\hline mu- & áná & 0 & mí & sa- & rar- & a \\
\hline 1 & filho & IS1 & $\mathrm{P} 1$ & levantar & TB & VF \\
\hline
\end{tabular}

No exemplo (6a), a transitividade é mais alta do que no exemplo (6b) por mostrar as seguintes características:

Participantes: dois (o pai é o agente e o filho é o objeto)

Cinese: ação

Aspecto: télico

Pontualidade: pontual

Afetação do objeto: total

Individuação do objeto: humano, animado, concreto, contável, definido e singular. 
Isso é diferente do exemplo (6b), que tem apenas um participante (o filho), que é ao mesmo tempo o agente e o paciente. Essas duas extensões indicam uma diferença na transitividade da ação. No exemplo (6a), o filho é levantado pela ação de alguém (o pai). No exemplo (6b), o filho se levanta sozinho (sem a ação de ninguém), trata-se de uma ação reflexiva. É por isso que o exemplo (6a) tem uma transitividade mais alta. O exemplo (6b), pelo fato de expressar uma ação reflexiva, tem uma transitividade baixa como já foi dito nos casos anteriores (4 e 5). Portanto, nesses casos (4 e 5) o problema é a mudança de valência, isto é, o derivativo indica o número de argumentos do verbo.

Apresentamos a seguir, sufixos derivativos com transitividade alta, mas que se diferenciam, essencialmente, pelo seu valor semântico.

\section{Caso 7}

Oração transitiva 7 com sufixo derivativo /-si-/(transitividade alta)

Radical verbal: -jisir- 'ensinar'

m’é jisirá bó lefaala

mé e $\varnothing-$ ji- sir- á bó le- faala

1s IS1s Pres ensinar TA $\quad$ VF $\quad 3 p(\mathrm{O} 1) \quad 9 \quad$ Francês (O2)

'Eu ensino francês para ele(a)s'

\section{Oração transitiva sem sufixo derivativo (transitividade alta)}

Raíz verbal: -jir- 'aprender'

m’é jirá dzúújî́ l’ábrezilję

mé e $\varnothing-\quad j i \gamma-\quad \varnothing-\quad a ́$ o- dzúújí le a- brezilję

1s IS1s Pres aprender TA VF 7 língua Con 2 brasileiro

'Eu aprendo a língua dos brasileiros' 
Os verbos dos exemplos (7a) e (7b) são todos transitivos porque apresentam objetos. O exemplo (7a) tem uma transitividade mais alta porque apresenta as seguintes características:

Participantes: três (Eu é o agente, ele(a)s é o objeto1, francês é o objeto2)

Cinese: ação

Aspecto: télico

Pontualidade: pontual

Afetação do objeto: total

Individuação do objeto1: humano, animado, concreto e contável.

Individuação do objeto2: não-humano, não-animado, abstrato e não-contável.

De fato, o exemplo (7a) apresenta três participantes sendo dois com o traço + humano (Eu e Ele(a)), e um abstrato, não-humano e não-contável (o francês ou a língua francesa). É por isso que a oração (7a) tem transitividade mais alta do que a oração (7b), que tem uma transitividade baixa porque apresenta as seguintes características:

Participantes: dois (Eu é o agente e a língua dos brasileiros é objeto)

Cinese: ação

Aspecto: télico

Pontualidade: pontual

Afetação do objeto: total

Individuação do objeto: não-humano, não-animado, abstrato e não-contável.

Podemos ver que a principal diferença entre as duas orações (7a) e (7b) acima, que é também o principal motivo que torna a transitividade mais baixa na oração (7b), é o fato de que a oração (7b) só tem dois participantes (um agente e um objeto), sendo que um deles apenas é humano (o agente: $E u$ ). A outra diferença entre essas orações é semântica. Ela reside no fato de que no exemplo (7b), a ação do agente $m \varepsilon$ 'eu' beneficia a ele mesmo (aprendo a língua dos brasileiros para meu próprio benefício). Portanto é uma ação autobenefactiva. Enquanto no exemplo (7a), a ação do agente (Eu) beneficia ao paciente (ele(a)s) que tem o traço + humano: ensino francês para o benefício dele(a)s). Portanto é uma ação benefactiva. Essa ação é marcada pela extensão -si-. Trata-se, portanto, de uma extensão que chamamos de benefactiva.

Apresentamos, abaixo, um caso cujos sufixos derivativos distinguem posições. 


\section{Caso 8}

Raiz verbal comum: -su-

Radicais verbais:

(a) -suus- 'pôr, colocar para baixo'

(b) -suur- 'pôr-se, colocar-se, para baixo' (para pássaros ou todo voador)

(c) -surug- 'descer'

Oração transitiva 8 com sufixo derivativo /-us-/(transitividade alta)

ygúr’ásuusá mwan’ójilá ntárí

ø- ygúrú a ø- su- us- á mu- ana ó jilá ø- ntárí

1 mãe IS1 Pres colocar TA VF 1 criança Loc sobre 7- cama

'A mãe coloca o filho na cama'

Oração intransitiva com o sufixo derivativo /- ur-/ (transitividade baixa)

(8b)

noj’o mî suur'ójil’ótî́ ju

ø- nojí o mî su- ur- a ó jilá ó- tî́ ju

1- pássaro IS1 P1 pausar Intr VF Loc sobre 4- árvore DEM

'O pássaro pousou em cima desta árvore'

Oração intransitiva com sufixo derivativo /-ruð-/(transitividade baixa)

(8c)

mwan'o mísurura m’oti

mu- áná o mí su- rur- á mó ó- tí

1- criança IS1 P1 descer Intr VF Loc 4- árvore

'A criança desceu da árvore' 
Das três orações acima, só a (8a) apresenta uma transitividade mais alta. Sendo a (8b) e a (8c) de baixa transitividade. A oração (8a) apresenta uma transitividade mais alta porque mostra as seguintes características:

Participantes: dois (a mãe é o agente e o filho é o objeto)

Cinese: ação

Aspecto: télico

Pontualidade: pontual

Afetação do objeto: total

Individuação do objeto: humano, animado, concreto, contável, definido e singular.

Enquanto as ações em (8b) e (8c) são de baixa transitividade porque não apresentam nenhum objeto ou paciente. São intransitivas. Um fato semântico que chama atenção nos verbos acima é que as três extensões expressam, todas elas, um movimento para baixo e não para cima. Porém, são extensões que indicam cada uma um movimento específico no plano espacial. É, portanto, uma extensão que chamamos de posicional. A extensão que indica o movimento contrário é -saar- 'levantar' (Cf. Caso 6 acima).

2.1 Sufixos derivativos que distinguem os traços +/- humano

Apresentamos, abaixo, um caso cujos sufixos derivativos que distinguem os traços (+/- humano). Desta vez, os derivativos diferenciam-se, principalmente, pelo tipo de paciente envolvido na transitividade: uma pessoa, um animal ou um objeto. Todas as orações são altamente transitivas.

\section{Caso 9}

Oração transitiva 9 com o sufixo derivativo $/-\varepsilon \varsigma-/$ (transitividade alta envolvendo uma pessoa)

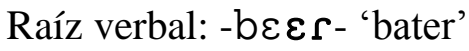

(9a).

nd’á béćré mwána

ndé a ø- bé- ér- é mu- áná

3s IS3s Pres bater TA VF 1 criança

'Ele bate na criança' 
Oração transitiva com o sufixo derivativo /-rعg-/ (transitividade alta envolvendo um objeto)

Radical verbal: -be reg- 'bater palmas, tambor'

(9b).

nd’á béréré ngómo

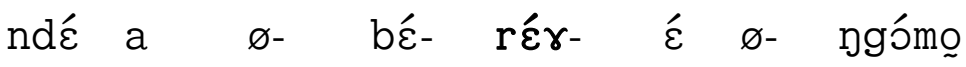

3s IS3s Pres bater TA VF 7 tambor

'Ele bate $o$ tambor'

A oração (9a) tem uma transitividade alta porque apresenta as seguintes características:

Participantes: dois (Ele é o agente e criança é o objeto)

Cinese: ação

Aspecto: télico

Pontualidade: pontual

Afetação do objeto: total

Individuação do objeto: humano, animado, concreto, contável, definido e singular.

A oração (9b) também tem uma transitividade alta porque apresenta as seguintes características:

Participantes: dois (Ele (a) é o agente e $o$ tambor é o objeto)

Cinese: ação

Aspecto: télico

Pontualidade: pontual

Afetação do objeto: total

Individuação do objeto: não-humano, concreto, não-animado.

A principal diferença entre essas duas orações está na individuação do objeto, isto é, no tipo de objeto ou paciente envolvido na ação transitiva: uma pessoa em (9a) e um objeto em (9b). Outra diferença semântica é que o verbo em (9a) é usado em ações que envolvem uma violência contra uma pessoa ou um animal (bater em uma pessoa ou um animal). Enquanto em (9b), o verbo é usado em ações que produzem ou envolvem o som ou a música (tocar um instrumento musical, um rádio, etc.). 
2.2 Sufixos derivativos que indicam o habitual em lembaama

Apresentamos, a seguir, outros sufixos derivativos que, desta vez, expressam um outro valor gramatical: o habitual. Trata-se da extensão habitual que os bantuístas chamam também de frequentativa.

\section{Caso 10}

Oração com a extensão habitual expressa pelo sufixo derivativo /-ag-/

É um sufixo /-CV-/, em que /g/ também se realiza $\gamma$. Vejamos alguns exemplos de orações:

Raíz verbal: -d3- 'comer'

Radical verbal: $-\mathrm{d} 3^{j}$ ag- 'ter o costume de comer, costumar comer, comer frequentemente'

(10a).

mwan'á dz'ákó

mu- aná a ø- dz- á á- kó

1 criança IS1 Pres comer VF 8 banana

'A criança come bananas'

$(10 b)$.

muan’ á dz járá ákó

mu- áná a d d $3^{j}$ á(r)- á á- ko

1 criança IS1 comer Hab Asp 8 banana

'A criança costuma comer bananas' 
(11a).

okáásí d3º́ nwá mal ’ánkálá

o- káásí dzwá á ø- nw- á ø- mali å nkálá

1 mulher aquela IS1 Pres beber VF bebida Con brava

'Aquela mulher bebe bebidas alcoolizadas'

(11b).

okáásí dzº́á nwáráá mal ’ánkálá

o- káásí dzwá á nw- á(r)- á ø- mali åa jkálá

1 mulher aquela IS1 beber Hab Asp bebida Con brava

'Aquela mulher costuma beber bebidas alcoolizadas'

Observando os exemplos acima, podemos observar que -ag- expressa uma ação que costuma acontecer ou que acontece com frequência. Trata-se, portanto, de uma extensão que chamamos de habitual ou frequentativa.

Em lembaama, a extensão frequentativa pode ser feita no presente e no passado tomando por base o infinitivo do verbo. Isso porque a extensão habitual sempre envolve a vogal final do verbo no infinitivo. Portanto, dependendo da vogal final do verbo no infinitivo, podemos ter as seguintes extensões: /-ag-/; /-og-/; /-eg-/, isso porque os verbos mbaama geralmente terminam em -a, -o, -e no infinitivo. Exceto o verbo - $l i$ 'estar' que termina em - $i$. Esse verbo tem como variante - $k a$ 'ficar'. Nesse caso, é essa variante que é usada no habitual. Vejamos exemplos de orações com a extensão habitual envolvendo outro tipo de vogal final:

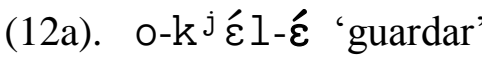

$$
\text { PV-Rad-VF }
$$

(12b).

bó má kำléré bááná jemĩní

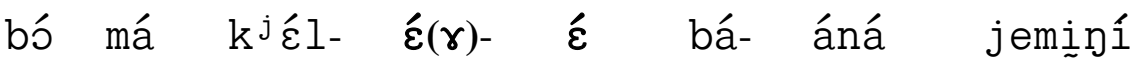

$3 p \quad$ IS3p guardar Hab Asp 2 criança bem

'Ele(a)s costumam cuidar bem das crianças' 
(13a).

o- kól- ó

PV- Rad- VF

'embriagar-se, engasgar, ficar bêbado'

(13b).

bó má kólóró mali

bó má kól- ó(

3p IS3p engasgar Hab Asp bebida

'Ele(a)s costumam ficar bêbado(a)s'

Podemos ter também extensão habitual no passado. Nesse caso, a extensão é /-ig-/. Isso porque ela se baseia na vogal final -i que é a marca do Aspecto perfectivo por excelência (Cf. no próximo capítulo sobre o sistema TAM em lembaama). Vejamos alguns exemplos com a extensão habitual no passado:

bó á kólí mali

bó a kól- í

$3 p \quad$ IS3 $p$ engasgar PFTV bebida

'Ele(a)s ficaram bêbado(a)s'

bó á kóliri mali

bó a kól- $i(\gamma)-\quad i \quad \varnothing-\operatorname{mali}$

3p IS3p engasgar Habp Asp bebida

'Ele(a)s costumavam ficar bêbado(a)s'

Aqui, na passagem do passado (Aspecto perfectivo) para o habitual passado, observamos uma mudança de tom na vogal final. Passamos do tom alto no passado para o tom 
baixo no habitual passado. Vale assinalar que o habitual pode também ser expresso sem a fricativa velar $\gamma$. Nesse caso, o encontro da vogal da extensão em harmonia com a vogal final produz um alongamento que vai marcar o habitual. Assim a marca de Aspecto é representada pelo alongamento da vogal final. De fato, observa-se, hoje em dia, que as duas formas estão em variação livre. Há uma síncope da consoante velar /g/ do morfema do habitual /-ag-/ na fala dos falantes jovens, por exemplo, se comparados aos velhos. Trata-se de um alongamento compensatório, porque a queda do segmento consonantal provoca o alongamento vocálico, isso é comum nas línguas. Vejamos este exemplo sem a fricativa velar $/ \mathrm{g} /$ :

$$
\begin{aligned}
& \text { okáásí dzw'á nwáá mal aánkála } \\
& \text { o- káásí dzwá a nw- áá o- mali åa nkála } \\
& 1 \text { mulher aquela IS1 beber Hab bebida Con brava }
\end{aligned}
$$

Vale lembrar também que a extensão habitual ou frequentativa é a única que se pode aplicar a todos os verbos do lembaama. Basta acrescentar à raiz do verbo o sufixo derivativo -ag- no presente ou -ig- no passado.

Segundo Nurse et al (2003, p. 72), o elemento *-a(n)g- se comporta tonalmente como uma extensão, mas ele entra frequentemente no paradigma da flexão (com vários significados imperfectivos tal como o durativo ou o habitual). Em lembaama, como vimos acima, esse morfema derivativo expressa o Aspecto: o habitual. Por isso foi tratado ao longo deste capítulo sem marca de tempo.

3 Quadro-resumo do sistema de derivativos mbaama

Apresentamos abaixo um quadro-resumo dos derivativos em lembaama: 
Quadro 8: Sistema dos derivativos mbaama

\begin{tabular}{|c|c|c|c|}
\hline Extensões & Valor gramatical & Valor semântico & \\
\hline $\begin{array}{l}1 .-\varnothing- \\
2 .-i g-\end{array}$ & $\begin{array}{l}\text { transitividade alta (TA) } \\
\text { intransitiva (Intr) }\end{array}$ & $\begin{array}{l}\text { Ação } \\
\text { Resultado/Estado }\end{array}$ & $\begin{array}{l}\text { Ex: derramar } \\
\text { Ex: estar derramado }\end{array}$ \\
\hline $\begin{array}{l}3 .-\varnothing- \\
4 .-u g-\end{array}$ & $\begin{array}{l}\text { TA } \\
\text { Intr }\end{array}$ & $\begin{array}{l}\text { Ação } \\
\text { Resultado/estado }\end{array}$ & $\begin{array}{l}\text { Ex: quebrar } \\
\text { Ex: estar quebrado }\end{array}$ \\
\hline 6.- $\varnothing-$ & $\begin{array}{l}\text { Intr } \\
\text { TA }\end{array}$ & $\begin{array}{l}\text { Ação } \\
\text { Resultado/ Estado }\end{array}$ & $\begin{array}{l}\text { Ex: estragar/enguiçar } \\
\text { Ex: estar estragado }\end{array}$ \\
\hline $\begin{array}{l}7 .-S- \\
8 .-l-\end{array}$ & $\begin{array}{l}\text { TA } \\
\text { transitividade baixa (TB) }\end{array}$ & $\begin{array}{l}\text { Ação } \\
\text { Resultado/estado }\end{array}$ & $\begin{array}{l}\text { Ex: ferir } \\
\text { Ex: ferir-se, estar ferido }\end{array}$ \\
\hline $\begin{array}{l}\text { 9.-us- } \\
\text { 10.-sug- }\end{array}$ & $\begin{array}{l}\text { TA } \\
\text { TB }\end{array}$ & $\begin{array}{l}\text { Ação } \\
\text { Resultado/Estado }\end{array}$ & $\begin{array}{l}\text { Ex: acordar } \\
\text { Ex: estar acordado }\end{array}$ \\
\hline $\begin{array}{l}\text { 11.-ar- } \\
\text { 12.-rag- }\end{array}$ & $\begin{array}{l}\text { TA } \\
\text { TB }\end{array}$ & $\begin{array}{l}\text { Ação } \\
\text { Resultado/Estado }\end{array}$ & $\begin{array}{l}\text { Ex: levantar } \\
\text { Ex: estar levantado }\end{array}$ \\
\hline $\begin{array}{l}\text { 13. }-\varnothing- \\
14 .-s i-\end{array}$ & $\begin{array}{l}\text { TA } \\
\text { TA }\end{array}$ & $\begin{array}{l}\text { Ação autobenefactiva } \\
\text { Ação benefactiva }\end{array}$ & $\begin{array}{l}\text { Ex: aprender } \\
\text { Ex: ensinar }\end{array}$ \\
\hline $\begin{array}{l}\text { 15.-us- } \\
\text { 16.-ur- } \\
\text { 17.-rug- }\end{array}$ & $\begin{array}{l}\text { TA } \\
\text { Intr } \\
\text { Intr }\end{array}$ & $\begin{array}{l}\text { Ação } \\
\text { Ação } \\
\text { Ação }\end{array}$ & $\begin{array}{l}\text { Ex: colocar (para baixo) } \\
\text { Ex: pousar } \\
\text { Ex: descer }\end{array}$ \\
\hline $\begin{array}{l}\text { 18.-er- } \\
\text { 19.-reg- }\end{array}$ & $\begin{array}{l}\text { TA } \\
\text { TA }\end{array}$ & \multicolumn{2}{|c|}{$\begin{array}{l}\text { Ação sobre um objeto humano/animal } \\
\text { Ação sobre um objeto produtor de música/som }\end{array}$} \\
\hline $\begin{array}{l}\text { 20. -ag-, -eg-, -og- } \\
\text { 21.-ig- }\end{array}$ & $\begin{array}{l}\text { habitual no presente } \\
\text { habitual no passado }\end{array}$ & $\begin{array}{l}\text { hábito/frequência } \\
\text { hábito/freqüência }\end{array}$ & \\
\hline
\end{tabular}

\section{Conclusão}

Par terminar, observamos que, em lembaama, nos sufixos derivativos do tipo /-VC-/, a consoante $\mathbf{g}$ se realiza $\gamma$. Em todos os verbos com esse tipo de raiz, atua o princípio da harmonia vocálica. Há sufixos derivativos que se iniciam por consoante e que invertem a consoante final (-er-, -reg-, -ur-, -rug- etc.). As extensões /-s-/ e /-l-/, que distinguem a transitividade alta da baixa no caso 4 acima, são extensões compostas por uma consoante. São do tipo /-C-/. São diferentes das extensões que costumamos ter nas línguas bantas que são em 
geral do tipo /-VC-/ (vogal com consoante). Constatamos que as extensões com alta transitividade são do tipo /-C-/, /-CV-/, /-VC-/ e expressam ações. Enquanto extensões com baixa transitividade são do tipo /-VC-/, /-CVC-/ e representam estados. A única exceção nessas extensões é -reg-, que é do tipo /-CVC-/, tem uma transitividade alta, mas só introduz uma ação envolvendo um objeto produtor de música ou de som.

O derivativo - $s-,-u s$ - parece ser o mesmo, de transitividade alta. Da mesma forma que -ig-, -ug-, onde a questão é de harmonia vocálica. Uma questão que se coloca é sobre o que parece reflexivo na tradução, porque aparece $-l-$, -rag-, -sug-. Como achar uma regularidade? Talvez os dois últimos se possam explicar pela alternância $r / s$.

Observamos também uma correlação entre o valor gramatical e o valor semântico dos sufixos derivativos em lembaama. Assim, vimos que seres humanos e animados são envolvidos em orações que apresentam uma transitividade alta (Cf. Caso 9). De fato, segundo os autores da proposta sobre a transitividade, quando um objeto humano está em competição com um objeto não animado, o objeto humano sempre prevalece. Esse fato, segundo eles, parece ser universal (THOMPSON; HOPPER, 1980, p. 260).

A transitividade é um continuum, orações sem objetos devem ser capazes de se localizar nesse continuum, mas não necessariamente no extremo fim da transitividade (Op.cit., p. 266).

O fato de termos uma oposição entre as ações e os estados, como vimos em lembaama, é também uma das características da transitividade que tem consequências morfossintáticas na direção escolhida. Esse fato é caracterizado como pontualidade pelos autores (Op. cit, p. 266).

Finalmente, constatamos que, em lembaama, as extensões que expressam um hábito, um resultado ou um estado são as mais encontradas. A extensão mais produtiva e mais fácil de formar ou reconhecer é aquela que marca o habitual ou a frequência: ela pode ser formada pela presença da fricativa velar entre a vogal da extensão e a vogal final ou simplesmente pela subtração da fricativa e consequentemente pela fusão dessas duas vogais em harmonia. 


\section{Capítulo V - TEMPO, ASPECTO E MODO EM LEMBAAMA}

\section{Introdução}

Para a análise do tempo, aspecto e modo em lembaama, além da tradição bantuísta ilustrada por Nurse (2003; 2008) e Creissels (2006), nós nos apoiaremos na teoria da enunciação elaborada por Benveniste (1974) e apresentada por Fiorin (1996; 2003).

Quando um falante produz um enunciado, ele diz algo, em um lugar e em um dado momento. Esse momento é o agora. Tudo isso pode ser resumido pela expressão latina ego (eu), hic (aqui), nunc (agora). Como o agora é gerado pela enunciação, ele se desloca ao longo do discurso permanecendo sempre agora que se torna, portanto, um eixo que ordena a categoria topológica da concomitância vs não-concomitância. Esta, por sua vez, articula-se em anterioridade vs posteridade. Assim, todos os tempos estão intrinsecamente relacionados à enunciação (FIORIN, 1996, p. 142-143).

Como já foi apresentado, no Capítulo III, referente à estrutura do verbo em lembaama, essa estrutura verbal em lembaama pode apresentar, no máximo, os seguintes elementos que se seguem numa ordem fixa:

(um sujeito $)+$ um índice do sujeito + (Neg) + uma Marca de Tempo + Raiz do verbo + (uma extensão) + uma vogal final (Marca de Aspecto) + (objeto (s) ou um índice do objeto) + (Neg).

Sendo que os elementos entre parênteses ou em negrito não são obrigatórios. Vejamos um exemplo:

nd 'ákajisirábódzandzaní

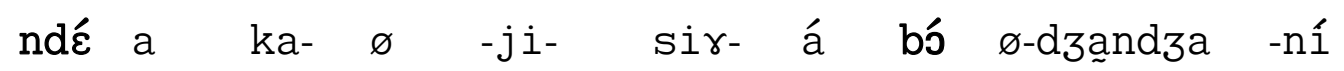

Suj IS3s Neg MT ensinar Ext. VF obj 7-trabalho Neg

'Ele(a) não vai ensinar-lhes o trabalho'

Todos os elementos localizados à esquerda e à direita da raiz do verbo -ji- 'ensinar' estão envolvidos na flexão verbal. 


\title{
10 Tempo
}

Na literatura, encontramos muitas definições da noção de Tempo (em maiúscula para significar categoria linguística), em geral, de ordem semântica. Para Comrie (1985), o Tempo é a expressão gramaticalizada do lugar no tempo, e Aspecto é a expressão gramaticalizada da consistência temporal interna (COMRIE, 1985, p. 6-9), ou seja, é a categoria gramatical que exprime a representação que o falante faz do processo expresso pelo verbo ou da constituição interna de uma ação ou de uma situação, isto é, a representação de sua duração, do seu desenvolvimento ou do seu acabamento (aspecto progressivo ou imperfectivo, perfectivo, resultativo, etc.) (DUBOIS, 1973, p. 73).

“O Tempo é uma categoria que marca na língua, a través de lexemas, de morfemas, de perífrases, a posição que os fatos referidos ocupam no tempo, tomando como ponto de partida o ponto-dêitico da enunciação" (COSTA, 2002, p. 17). A exemplo de Costa (2002) e Fiorin (2003), distinguiremos Tempo (categoria linguística) de tempo (tempo físico). Fiorin acrescenta ao tempo linguístico e físico a dimensão cronológica que corresponde ao tempo dos acontecimentos, o tempo do calendário. O tempo físico é marcado pelo movimento dos astros, que determina a existência de dias, meses, anos, etc. (FIORIN, 2003, p. 166).

Interessa-nos, aqui, o tempo linguístico, por estar relacionado à enunciação, que tem seu centro no presente da instância da fala. Sua singularidade é marcada da seguinte maneira:

a) Seu eixo ordenador e gerador é o momento da enunciação;

b) Está relacionado à ordenação dos estados e transformações narrados no texto.

\begin{abstract}
Daí decorre que existem na língua dois sistemas temporais: um relacionado diretamente ao momento da enunciação e outro ordenado em função de momentos de referência instalados no enunciado. Assim, temos um sistema enunciativo no primeiro caso e um enuncivo no segundo. Ocorre, no entanto, que o momento de referência está relacionado ao momento da enunciação, já que este é o eixo fundamental de ordenação temporal na língua. Por isso, ao momento da enunciação aplicamos a categoria topológica concomitância vs não-concomitância (anterioridade vs posteridade) e obtemos três momentos de referência: concomitante, anterior e posterior ao momento da enunciação.

São três os momentos estruturalmente relevantes na constituição do sistema temporal: momento da enunciação (ME), momento da referência (MR) e momento do acontecimento (MA) (FIORIN,1996, p. 145-146).
\end{abstract}

Parece-nos haver um consenso na maioria das línguas do mundo sobre a existência desses três tempos cuja relação pode ser representada da seguinte maneira esquemática, que marca o momento da enunciação: o agora - em que se situa o falante: 


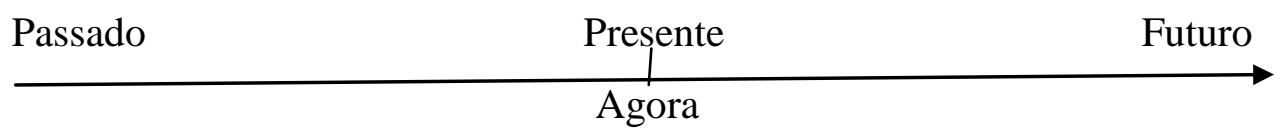

O momento de referência presente é um agora, pois ele coincide com o momento da enunciação. $\mathrm{O}$ momento de referência passado indica uma anterioridade ao momento da enunciação; o futuro, uma posteridade a esse momento (FIORIN, 2003, p. 166).

Os Tempos não refletem o mundo, mas a nossa categorização do mundo, em consequência, as línguas dividem a linha do tempo de maneira diferente. O resultado disso é que temos um número diferente de tempos, pois, em princípio, a linha do tempo pode ser repartida em muitos tempos. Assim, muitas línguas bantas, mas não aquelas mais usadas como o suaíli e o xona, são conhecidas pelas suas múltiplas divisões do tempo (NURSE, 2003, p. 99).

A maioria das línguas bantas têm um, dois, três ou quatro passados. Hyman (1980b) cita uma língua do subgrupo Grassfields ${ }^{27}$ que tem cinco passados e cinco futuros e a língua gogo do oeste também tem cinco. As línguas com dois (49 línguas) e três passados (47 línguas) constituem a maioria. São seguidas por aquelas com apenas um passado (23 línguas) e, finalmente, com quatro (16 línguas). Das línguas com dois, três e quatro passados, são citadas respectivamente: o rundi, o haya e o bemba em Hyman e Waters (1984). Nas línguas com três passados, o passado próximo refere-se normalmente aos acontecimentos de hoje, começando pela manhã (na maioria das línguas bantas, o dia começa com o nascer do sol e termina com o pôr do sol), o passado médio refere-se tanto aos acontecimentos de ontem, ou de ontem e de alguns dias antes; e o passado remoto relaciona-se aos acontecimentos anteriores àqueles do passado médio.

O quarto passado, nas línguas que o possuem, refere-se a eventos que ocorreram imediatamente antes do momento da enunciação. Nas línguas com dois passados, o passado recente refere-se a ambos os acontecimentos, os de hoje de manhã, ou os de hoje e de ontem, e o passado remoto refere-se a eventos anteriores. Em línguas com um passado, este tempo refere-se a qualquer evento anterior ao momento da enunciação.

As divisões gerais do tempo refletem as do passado, exceto aquela que tem a semântica do 'presente' que, muitas vezes, coincide com o futuro próximo.

O futuro, também, possui duas ou três formas discretas nas línguas bantas. Uma que se refere a eventos que vão ocorrer algumas horas depois do momento da enunciação: é o

\footnotetext{
${ }^{27}$ Assim como o banto, o Grassfields é um subgrupo do bantóide da família benuê-congolesa (cf. HEINE; NURSE, 2000, p. 31-35).
} 
chamado futuro próximo. Outra que se refere a eventos que vão acontecer alguns meses ou anos depois do momento da enunciação, é o chamado futuro distante. As línguas com dois futuros distinguem o próximo do distante. Com relação ao número de futuros, o suaíli e aghem em Hyman e Waters (idem), hehe (NURSE, 1979a) e o logooli são, respectivamente, línguas com um, dois, três e quatro futuros (NURSE, 2003, p. 100).

Em lembaama o tempo pode ser codificado de duas maneiras:

a) pela flexão verbal, isto é, por morfemas marcadores de tempos ou morfemas de tempo (MT), antepostos ao radical do verbo.

b) pelo uso de verbos auxiliares que precedem o verbo principal. São verbos como odzé 'ir', omana 'acabar', obuuna 'poder', osaga 'procurar', etc.

Vejamos como se manifesta o Tempo em lembaama:

\title{
$1.1 \mathrm{O}$ presente
}

O presente refere-se ao momento da enunciação: o agora, que coincide com o momento de referência presente. Ele é marcado pela fluidez e pela efemeridade.

\begin{abstract}
O presente marca uma coincidência entre o momento do acontecimento e o momento de referência presente. Deve haver no presente uma tripla coincidência: $M A=M R=$ $\mathrm{ME}^{28}$. No entanto, é necessário precisar o que é a coincidência mencionada, já que o momento da enunciação é difícil de delimitar, na medida em que foge sem cessar. $\mathrm{Na}$ verdade, o presente é uma abstração do espírito, uma vez que, como mostra Guillaume, ele se recompõe com instante que acabaram de passar e com instantes que ainda vão passar (1968: 51). Por isso, a parcela de tempo do momento de referência que está relacionada ao momento da enunciação pode variar em extensão (...) O que há sempre é uma coincidência entre o momento do acontecimento e o momento de referência (FIORIN, 1996, p. 149).
\end{abstract}

Em lembaama, o presente não é marcado (talvez por ele ser óbvio para os participantes do ato da enunciação). É, portanto, o caso defaut. Isto é, a marca de tempo (MT) que aparece antes do verbo é zero.

(2)

\section{bsíléwóbólémbáámá}

bsí lé $\varnothing$-wób- ó lé- lémbáámá

$1 \mathrm{p} \quad \mathrm{IS} 1 \mathrm{p}$ Pres falar VF 9 Lembaama

'Nós falamos/estamos falando/falaremos lembaama'

\footnotetext{
${ }^{28}$ Não importa que a simultaneidade seja real ou não. A linguística não opera com o mundo "real”, mas com o mundo da linguagem e, por conseguinte, com efeitos de sentido, (FIORIN, 1996, p. 149).
} 
Esse exemplo mostra uma coincidência entre o ME e o MR. Ele pode ser traduzido de três maneiras diferentes em português: ele pode ser interpretado tanto pelo presente pontual e durativo (quando o momento de referência é mais longo do que o momento da enunciação ${ }^{29}$ ) quanto pelo futuro. Só o contexto, ou seja, a situação vai definir o significado dessa oração.

\section{$1.2 \mathrm{O}$ passado}

O passado marca uma anterioridade entre o momento do acontecimento e o momento de referência presente. O lembaama distingue três tempos passados: um passado recente, um distante e um remoto. Os dois primeiros são, respectivamente, marcados por morfemas específicos do tipo CV: mi- e maa- que são antepostos à raiz do verbo. O remoto é marcado pelo verbo - $k i$ 'estar' (no passado) e pelo morfema de tempo mí- (marca do passado recente) anteposto ao verbo principal.

\section{$1.3 \mathrm{O}$ passado recente}

O passado recente ( $\mathrm{P} 1)$ expressa um acontecimento que se realizou um pouco antes do momento da enunciação (presente). Tanto o momento de referência quanto o momento do acontecimento são passados. O P1 é marcado pelo morfema de tempo mí-, anteposto à raiz do verbo.

báán ’ámídzánama

$\begin{array}{llllllll}\text { bá- } & \text { áná } & \text { a } & \text { mí } & \text {-dz- } & \text { á } & \varnothing \text { - } & \text { nama } \\ 2 & \text { criança } & \text { IS2 } & \text { P1 } & \text { comer } & \text { VF } & 1 & \text { carne }\end{array}$

'As crianças comeram carne' (faz pouco tempo)

${ }^{29}$ Esse uso representa no sistema temporal presente o que o imperfeito faz no subsistema do pretérito (FIORIN,1996, p. 149). 


\subsection{O passado distante}

O passado distante (P2) expressa uma ação que já se realizou ou que já foi realizada há bastante ou muito tempo antes do momento da enunciação (presente). O P2 é marcado pelo morfema de tempo máá- anteposto à raiz do verbo. Assim como ocorre com os outros Tempos que vimos até agora, aqui também não há marcação do aspecto, já que não há mudança na vogal final do verbo.

\section{báán ’ámáádzánama}

bá- áná á máá -dz- á $\quad$ a- nama

2 criança IS2 P2 comer VF 1 carne

'As crianças comeram carne' (faz um tempo)

\subsection{O Passado remoto}

O passado remoto $(\mathrm{P} 3)$ se refere a uma ação anterior a outra ação passada. O passado remoto é expresso pela combinação do verbo auxiliar - $l i$ 'estar', que tem a forma $-k i$ no passado associado à forma do P1 (mí + verbo).

ntin’ébomádzí,

$\varnothing-$ ntini é bó má $\varnothing \quad-d 3^{-}$í

7 momento con $3 p$ IS3s MT vir PFTV

'Quando eles chagaram,

bsílékílémímaná

bsí lé $\varnothing$-k- í lé mí -man- a

1p IS1p MT estar VF IS1p P1 acabar VF

nós tinhamos acabado'

Esse Tempo é mais facilmente identificado quando se trata de relatar um fato anterior a outro no passado. Ele é marcado pelo morfema de passado recente mí-, colocado antes do verbo principal. Podemos notar que é o verbo auxiliar - $k i$ 'estar/ficar', não o principal, que tem a marca do aspecto perfeito ou do perfectivo (-1́) como vogal final. 
Há, portanto, uma correlação entre tempo e aspecto, sendo que o aspecto é marcado na primeira forma verbal e o tempo, na segunda.

\subsection{O futuro}

O futuro expressa uma posteridade do momento do acontecimento em relação a um momento de referência presente; indica uma ação que vai se realizar.

Em lembaama, distinguimos duas formas verbais para expressar o futuro:

a) sem marca de tempo e, portanto, que se confunde com o presente (cf. exemplo (2), acima). Expressa a ideia de um futuro mais próximo, podendo coocorrer com advérbios de tempo como:

i) lobi 'hoje',

ii) ossuugha 'amanhã',

iii) mbsa-ossuugha 'depois de amanhã'

mbs'osuurá

mbisá- osuurá

atrás de amanhã

iv) ngula-mbisa-ossuugha 'daqui quatro dias'

ngulambs' osuurá

Ø-ngula- mbisá- osuurá

7-lado atrás de amanhã

(6)

loßí mwáná ju alila

loßí mu- áná ju a $\varnothing \quad$-lil- a

hoje 1 criança esta IS1 F1 chorar VF

'Hoje esta criança vai chorar' 
b) introduzida pelo verbo auxiliar odze 'ir', que expressa a ideia de um futuro distante. Esse futuro pode ser introduzido por uma expressão de tempo como tsughu lemõ 'um dia'.

(7)

mwánáju, adz'okirir'owóró

mw- áná ju, a $\varnothing \quad-d z-\varepsilon \quad$ $\quad \varnothing \quad$-kirir- a o- wóró

1 criança esta, IS1 MT ir VF 12 tornar-se VF 1 soldado

'Esta criança tornar-se-á/ vai tornar-se soldado' (um dia)

Temos no exemplo acima uma forma verbal composta que expressa uma ideia planejada para se realizar em um futuro distante (um dia). Esse futuro é introduzido pelo verbo auxiliar odze 'ir', que acompanha o verbo principal okiriga 'tornar-se' (no infinitivo).

Dessa forma, em lembaama, os únicos tempos bem marcados por morfemas são os dois passados: o recente e o distante. O passado remoto é marcado pelo verbo auxiliar -li 'estar' que se torna - $k i$ no passado. O futuro distante é marcado pela gramaticalização do verbo odzé 'ir', que desempenha o papel de auxiliar, como em muitas línguas do mundo (francês, inglês, português, etc.). O presente é um caso default. Ele é marcado pelo morfema zero. Expressa também o futuro e o presente progressivo. Observamos que todos os morfemas ou lexemas (no caso do futuro com odzé 'ir'), marcadores de tempos aparecem sempre à esquerda da raiz verbal ou do verbo principal (no caso do futuro).

\section{Aspecto}

Encontramos diversas definições de Aspecto na literatura. Todas diferenciam Aspecto de Tempo, porque dizem respeito a uma visão interna do processo. A partir da definição estabelecida por Comrie (1976), Nurse conceitualiza o Aspecto como:

Aspect is grammaticalized expression of 'internal temporal constituency', ou seja, o Aspecto é a expressão gramaticalizada da constituição interna do tempo (NURSE, 2008, p. 80,129).

Da mesma maneira, temos também outras definições: 
O Aspecto diz respeito ao tempo, mas ao "contorno ou distribuição temporal" de um acontecimento ou estado de coisas e não à sua "localização no tempo" (LYONS, 1979, p. 331).

O Aspecto é a visão objetiva da relação entre o processo e o estado expressos pelo verbo e a ideia de duração e desenvolvimento. É a representação espacial do processo. (CASTILHO, 1968, p. 14)

O Aspecto designa, portanto, uma categoria gramatical que manifesta o ponto de vista do falante em relação à ação expressa pelo verbo. Pode ele considerá-la como concluída, isto é, observada no seu término, no seu resultado, ou pode considerá-la como não concluída (CUNHA; CINTRA, 2007, P. 396).

O levantamento da literatura sobre as línguas do mundo sugere as seguintes categorias de aspectos como as mais difundidas: o imperfectivo, que contrasta com o perfectivo e o anterior; o progressivo e o habitual. Além desses cinco, há um sexto Aspecto, menos difundido, apresentado por Nurse (2003, P. 96) e que é bastante difundido nas línguas bantas, exceto em lembaama: o persistivo. Trata-se de um aspecto que denota uma atividade que começou no passado e que continua até o momento da enunciação. Em português, seria algo como 'ainda estar + verbo no gerúndio'.

\section{$2.1 \mathrm{O}$ perfectivo}

Quando falamos do contraste perfectivo (PFTV)/ imperfectivo (IPFV), retomamos a afirmação de Creissels (2006, p. 196) de que existem, em muitas línguas, duas formas verbais distintas que se alternam na narrativa. Uma põe em sequência os eventos que constituem a trama da narrativa (é esta forma verbal que chamamos de perfectivo). A outra descreve as situações em que se desenrolam ou acontecem esses eventos (é essa que chamamos de imperfectivo).

Assim, o fato tratado perfectivamente ocupa uma determinada posição na linha de tempo e é visto como global, como um ponto fechado, como um todo, um conjunto, do qual não interessa demonstrar a constituição temporal interna, isto é, se durou um certo período de tempo ou não, se o falante quer expressar apenas o início da sua realização, ou o meio, ou o fim. O evento não é observado quanto à maneira como a fração de tempo nele contida é distribuída. Dessa forma, o perfectivo expressa o fato enunciado como global, sem parcializar ou marcar de alguma forma a sua temporalidade interna (NURSE, 2003, p. 96). 
Em lembaama, o aspecto perfectivo é marcado pela vogal final -í posposta à raiz ou ao radical do verbo, podendo coocorrer com advérbios de tempo como:

a) mbari 'ontem',

b) mbisá-mbari 'anteontem', mbsámbari

mbisá- mbari

atrás de ontem

c) ngula-mbisa-mbari 'antes de anteontem'(há quatro dias).

ngulambsámbari

$\varnothing$-ngula- mbisá- mbari

7-lado atrás de ontem

(8)

báán’ádzínama mbari

bá- áná á $\varnothing \quad \begin{array}{llll}-d z- & 1 & \varnothing- & \text { nama mbari }\end{array}$

2 criança IS2 MT comer PFV 1 carne ontem

'As crianças comeram carne ontem'

$\mathrm{O}$ aspecto perfectivo se encontra principalmente nas narrativas: nos contos e fábulas. Vejamos estes exemplos: 
$(9)^{30}$

nguj’ ódzí na Đkoso,

$\varnothing$ - ngujá ó $\varnothing \quad$-dz- $1 \hat{1} \quad$ na $\varnothing$ - nkoso

1- javalí IS MT vir PFTV com 7 ferro

'o javalí trouxe o ferro,

nd’ótúlí, nguj' ó vrîri

ndé ó $\varnothing \quad$-tul- 1 $\quad \varnothing \quad \varnothing$ - ngujá ó $\varnothing \quad$-vrír- i

3s IS3s MT forjar PFV 1 javalí IS1 MT voltar PFV

ele forjou. O javalí voltou'

$(10)^{31}$

y’ent jéré, bóamaja, olúm’ apara ndzásí, odzî́siri

ya e-ntjjére bó a ma -j- a o-lúmí a $\varnothing^{32}$-par- a $\varnothing$-ndzási

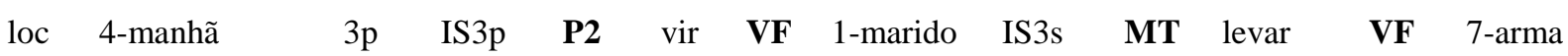

'De manhã,(quando) eles chegaram, o marido que levava uma arma no ombro

odzísiri ó mpaan’ótí

$\begin{array}{lllllll}\circ & \varnothing & \text {-dzísir- } & \text { i } & \text { ó } & \text { mpaaní } & \text { o-tî́ } \\ \text { IS3s } & \text { MT } & \text { esconder-se } & \text { PFTV } & \text { loc } & \text { perto de } & \text { 3-árvore }\end{array}$

escondeu-se perto de uma árvore'

Temos acima um exemplo com marcas de tempo e de aspectos: ma- (marca do passado distante), e $\varnothing$ - (marca que remete ao presente). Essa marca zero representa algo como um "pretérito imperfeito". Este apresenta os fatos como simultâneos, como formando um quadro contínuo, ou melhor, como vinculados ao momento de referência pretérito (FIORIN,1996, p. 158). Trata-se da descrição de uma cena no passado. Os fatos principais estão tanto no passado distante (marcado por $m a-$ ), como no perfectivo marcado pela vogal final -i no verbo dzisighi 'escondeu-se'. O exemplo mostra, portanto, uma convivência entre

\footnotetext{
${ }^{30}$ Este exemplo é tirado da fábula mbaama : o ferreiro $\boldsymbol{e}$ a tartaruga que se encontra no nosso corpus no apêndice.

${ }^{31}$ Exemplo tirado da obra de Adam (1971, p . 248)

${ }^{32}$ Trata-se do morfema zero que marca um presente. Aqui ele expressa um aspecto imperfectivo, é traduzido em português por um pretérito imperfeito. Ele indica uma ação em andamento ou uma descrição.
} 
acontecimentos que estão no primeiro plano - e levam as marcas do aspecto perfectivo, e a descrição que está no segundo plano, que não levam nenhuma marca do aspecto imperfectivo, pois em lembaama o imperfectivo é expresso pela ausência de marca aspectual.

\section{$2.2 \mathrm{O}$ imperfectivo}

O imperfectivo expressa a temporalidade interna de uma ação de diversas maneiras: considerando-a como um fragmento de tempo que se desenrola (expressão de cursividade), selecionando fases desse tempo interno (expressão das fases inicial, intermediária ou final), ou expressando, ainda estados resultativos que deem relevância linguística à constituição temporal interna de um processo que os antecedeu (COSTA, 2002, p. 30). Isto é, o imperfectivo (IPFV) expressa uma ação em curso.

Dados das línguas bantas citadas por Nurse (2003) indicam que os IPFV podem ser expressos pela flexão, que costuma vir no final, ou pelo uso de verbos auxiliares. Não há nenhuma flexão no final do verbo, já que a vogal final permanece a mesma do infinitivo. Portanto, em lembaama, o aspecto imperfectivo se expressa pela ausência de marca. Vejamos alguns exemplos.

Se um pai fizesse a seguinte pergunta para suas filhas ao chegar em casa, usando o verbo odzé 'ir':

(11a).

békùnilédze

bé kùni lé $\varnothing \quad-d 3^{-} \quad \varepsilon$

$2 \mathrm{p}$ onde IS3p MT ir VF

'(Para) onde vocês vão/estão indo/irão ?' 
A resposta imediata poderia ser esta:

(11b).

\section{bsílédzetériri}

bsí lé $\varnothing \quad$-dz- $\quad \varepsilon \quad \varnothing$-tériri

$1 \mathrm{p} \quad$ IS1p $\quad$ MT brincar $\quad$ VF $\quad$ 7-poço

'Nós vamos/estamos indo/iremos ao poço'

Como podemos observar, a marca de tempo do verbo é zero e a vogal final do verbo permanece a mesma do infinitivo, tanto na pergunta quanto na resposta. Além do mais, a tradução nos remete tanto ao presente pontual, ao presente progressivo - em português, 'vocês vão/estão indo' e 'Nós vamos/estamos indo' - quanto ao futuro do presente - 'vocês irão' e 'nós iremos'. Em todo caso, o processo está em curso. É por isso que se trata de um aspecto imperfectivo. O que importa aqui é o fato de a ação estar em desenvolvimento; o Tempo presente/futuro contém o aspecto imperfectivo; o que evidencia que o Aspecto é mais fundamental do que o Tempo nessa língua.

\subsection{O progressivo}

O progressivo para nós, faz parte do Imperfectivo. Mas para Nurse (2003, p. 98), é um aspecto diferente do imperfectivo. Segundo ele, o progressivo (PROG) é a quarta categoria dos aspectos. Ele representa uma ação em curso, que está acontecendo faz apenas alguns segundos, com relação ao momento da fala. O início e o fim da ação não importam. O que importa é o fato da ação estar em curso (NURSE, 2008, p.139). Assim, não é fácil distinguir o PROG de categorias semelhantes como o contínuo. Muitas línguas bantas podem contrastar essas duas categorias. Quando os dados fornecem simplesmente a tradução em uma língua mais conhecida como o inglês ou o português, sem contexto, não é possível saber de qual dessas duas categorias se trata, progressivo ou imperfectivo.

Vamos ver que não é o caso do lembaama, que difere das outras línguas bantas nos pontos mencionados acima.

Para Nurse, o progressivo parece ser uma categoria tão frequentemente renovada que é difícil dizer se o banto antigo o expressou por uma simples forma flexionada. Nas línguas 
bantas estudadas por Nurse (2003), ele é expresso por formas gramaticalizadas que visivelmente derivam de 'ser/estar' ou 'ter/haver' mais locativo e/ou deverbal, como 'estar com, estar em, ter/haver, etc.' (cf. BASTIN, 1989b; 1989c; HEINE et al, 1993). O banto tem vários verbos traduzidos em inglês como 'ser/estar' que, muitas vezes, fazem sentido no progressivo porque indicam um estado temporário (-li, -ri): 'estar em um lugar particular', que se torna 'estar em um momento particular'. 'Ter/haver', no banto, muitas vezes deriva de 'estar + com'. Assim, os presentes progressivos que envolvem -li/-ri mais -ku-/-i- (substantivo verbal), geralmente acompanhados de um locativo, são comuns. Os não-presentes muitas vezes acrescentam um auxiliar para indicar o tempo. As seguintes línguas servem de exemplos: luvale K14 (YUKAWA, 1987b), luba L33 (BECKETT, 1951), umbundu R11 (SCHADEBERG, 1990).

Concordamos, de fato, com Bastin, citada por Nurse (2003, p. 98). O aspecto progressivo em lembaama pode envolver o verbo -li 'estar'. Mas não necessariamente. Vejamos estes exemplos:

\begin{tabular}{|c|c|c|c|c|c|c|c|c|}
\hline bsí & le & $\varnothing$ & $-1-$ & $i$ & lé & $\varnothing$ & -wób- & כ́ \\
\hline $1 \mathrm{p}$ & IS $1 p$ & MT & estar & VF & IS $1 p$ & MT & falar & VF \\
\hline
\end{tabular}

Entretanto, é possível expressar o mesmo aspecto sem usar o verbo auxiliar -li 'estar'.

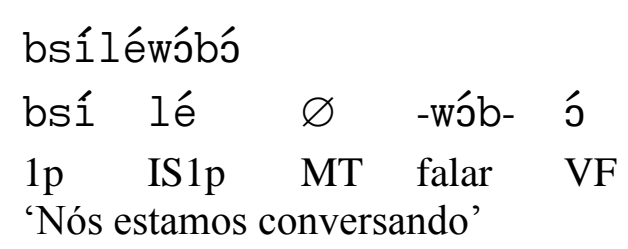

Porém, essa forma significa tanto 'estamos falando' como 'falamos' ou 'falaremos'.

O único efeito de sentido diferente entre essas duas orações é que a segunda (12b), pela ausência de - $l i$ 'estar', é a única que pode também significar uma ação futura. Como já foi dito, é uma forma default (sem marca de tempo, nem de aspecto). Em todo caso, trata-se de um progressivo que é também um imperfectivo, no sentido em que a ação não acabou, ainda está em andamento. 


\subsection{O habitual}

Concordamos com Nurse (2003, p. 98), ao afirmar que a forma habitual é um imperfectivo, no sentido em que a ação está em curso. Etudiosos das línguas africanas, porém, podem divergir em relação a afirmação de que o habitual é um tipo de aspecto imperfectivo. Para Comrie (1976) o imperfectivo contrasta com o perfectivo, e é um termo geral para habitual, progressivo e contínuo. Estudiosos mais recentes aprovam também o contraste básico entre imperfectivo e perfectivo. Nesse cenário, o imperfectivo representa um acontecimento ocorrendo em um longo período indefinido.

Para Creissels (2006, p. 183), o habitual é um tempo, e o autor propõe um presente habitual, que se refere a um acontecimento apresentado como se produzindo habitualmente, em um período de tempo que engloba o momento da enunciação.

O habitual (Hab), em lembaama, é um Aspecto e indica uma atividade que caracteriza um longo período ou algo que acontece por muito tempo, de modo costumeiro, repetido. Ele é muitas vezes associado, na maioria das línguas bantas, com reflexos da protoforma herdada do protobanto: $-a(n) g a$, no final do verbo, ou seja, à direita da raiz verbal. A final - $a(n) g a$ é muitas vezes associada ao IPFV. Um morfema zero, não marcado no tempo ou no aspecto, indicando que uma ação caracteriza um longo período não especificado, ocorre em diversas línguas bantas. Esse morfema é usado quando a distinção entre o IPFV, o PROG ou o Hab não é importante, relevante ou conhecida.

Em lembaama, o habitual é um aspecto marcado pela extensão (-ag-) realizado [-ar-], e pela vogal final, que repete a vogal da extensão.

\begin{tabular}{|c|c|c|c|c|c|c|c|c|}
\hline bsî & le & $\varnothing$ & -táám- & ar- & a & e- & tsurú & e- \\
\hline & IS1p & MT & brincar & Hab & Asp & 4 & Dia & 4 \\
\hline
\end{tabular}

'Nós brincamos/costumamos brincar todos os dias'

bsîletáámaa

bsí le $\varnothing$-táám- a( $(\gamma)$ a

$1 \mathrm{p}$ IS1p MT brincar Hab Asp

'Nós costumamos brincar' 
Nesse exemplo, de fato, podemos observar a presença do morfema (-ag-) realizado [-ar-] posposto à raiz do verbo. A marca de aspecto está também no alongamento da vogal final. De fato, observa-se, hoje em dia, que as duas formas estão em variação livre, o que mostra uma instabilidade, que pode vir a dar numa mudança, principalmente pelo fato de estar associada à fala dos jovens: há uma síncope da consoante velar/g/ do morfema do habitual /-ag-/ na fala dos falantes jovens, por exemplo, se comparados aos velhos. Assim, o encontro das vogais em harmonia (a da extensão habitual e a da vogal final do verbo) produz um alongamento. Trata-se de um alongamento compensatório, porque a queda do segmento consonantal provoca o alongamento vocálico, fato comum nas línguas. Dessa forma, no lugar de: táámara (para os velhos), temos: táámaa (para os jovens) 'brincar habitualmente'.

O habitual pode ser encontrado em provérbios, e se justifica pelo fato de os provérbios serem uma fonte importante da sabedoria do povo mbaama. Se o habitual em lembaama fosse um tempo como em português, seria o presente que Fiorin (2003, p. 169) chama de "presente omnitemporal ou gnômico. Vejamos o provérbio abaixo em que aparecem os verbos okwá 'morrer', osiílá 'sobrar/ficar':

\begin{tabular}{|c|c|c|c|c|c|c|}
\hline má & $\varnothing$ & -kw- & $a(\gamma)-$ & $a$ & bá- & ári \\
\hline IS2 & MT & morrer & Hab & Asp & $2-$ & pessoa \\
\hline
\end{tabular}

másilaabáári

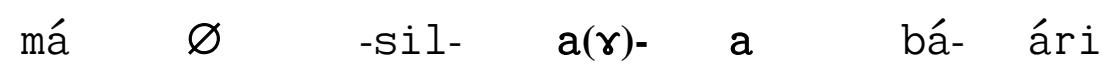

IS2 MT sobrar Hab Asp 2- pessoa

sobram pessoas habitualmente'. Isto é, o mundo não acaba, apesar das mortes. 
2.5 O habitual passado

O aspecto habitual no passado constrói-se a partir do perfectivo. Expressa uma ação que costumava ser realizada no passado. O passado habitual é marcado por um morfema de tempo zero anteposto à raiz do verbo. $\mathrm{O}$ aspecto habitual no passado (Habp) é expresso pela extensão /-ig-/ que se realiza [-ið-], posposta à raiz do verbo. Assim como no habitual presente, a consoante velar pode ser omitida, o que gera o alongamento da vogal final que apresenta uma harmonia vocálica e tonal com a vogal da extensão, isto é, identidade, repetição, da vogal da extensão (que está sempre na penúltima posição da estrutura verbal), no final do verbo (na vogal final). Vejamos este exemplo:

báán ’ádzirinama

bá- áná a $\varnothing \quad-d z^{-} \quad i(\gamma)-\quad i \quad \varnothing-$ nama

2 criança IS2 MT comer HabP Asp 1 carne

'As crianças comiam/ costumavam comer carne'

O aspecto habitual no passado encontra-se também na literatura (nos contos e fábulas). Vejamos um exemplo tirado da fábula 'o ferreiro e a tartaruga'(cf. Corpus em Apêndice).

mvur' akîí m’ osí

mv- uru a $\varnothing \quad-k-i(\gamma)$ i má o- sí

1 pessoa IS MT ficar Habp Asp loc 12 país

'Num país vivia um homem' (Introdução comum a muitos contos)

Na verdade, em lembaama, no que diz respeito ao habitual, estamos diante de um caso interessante: há uma interação entre tempo e aspecto, no habitual (presente/passado), pois é uma categoria verbal que apresenta elementos morfológicos e semânticos relativos tanto ao Tempo (pela marca de tempo que é zero) quanto ao Aspecto, pelo fato de veicular uma ação costumeira e de ser marcado por um morfema derivacional colocado à direita da raiz verbal. Porém, para nós, sempre se trata de um aspecto, pois partimos do princípio de que o aspecto é 
sempre marcado à direita da raiz do verbo, mas o Aspecto também é uma extensão pela

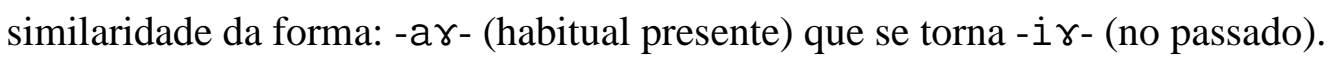

Resumindo, lembaama apresenta os seguintes aspectos:

1- o perfectivo, marcado pela vogal final -i;

2- o imperfectivo, sem marca específica, que indica uma ação em curso ou não concluída. Nesse sentido, consideramos também o habitual como um aspecto imperfectivo. Além disso, partimos da constatação de que, em lembaama, como na maioria das línguas bantas, o aspecto é geralmente marcado à direita da raiz verbal. Assim, o habitual é marcado pelos morfemas derivativos -ag- (para o habitual presente) e -ig- (para o habitual passado), e a vogal final que repete a vogal da extensão. Notamos que o habitual pode ser expresso pela eliminação da consoante velar, que resulta em um alongamento da vogal final do verbo.

Observamos, finalmente, que há apenas um aspecto que não é marcado em lembaama: o imperfectivo. O progressivo, que consideramos uma forma de imperfectivo, é marcado pelo verbo - $l i$ 'estar', em desaparecimento, que desempenha o papel de auxiliar que acompanha o verbo principal e, portanto, se coloca à esquerda do verbo principal. Dessa forma, como a duração encontrada no imperfectivo, encontra-se também no progressivo, logo só há dois aspectos nesta língua: o perfectivo e o imperfectivo.

\section{O Modo}

Modo refere-se à maneira pela qual o falante apresenta a verdade da proposição no discurso e no contexto do mundo real. Aqui estão incluídas expressões de probabilidade, possibilidade e certeza. Distinções de modo expressam o que o falante quer fazer com a proposição em uma conversação particular. Isso inclui a expressão de uma asserção (indicativo), a não-asserção (subjuntivo), uma ordem (imperativo), e um aviso ou uma advertência (admonitivo). Mesmo quando o modo é expresso como uma flexão verbal, ele tem toda a proposição no seu escopo, e não modifica apenas o verbo. Essas duas propriedades tornam o modo menos relevante para o verbo do que o Tempo e o Aspecto. Assim, devemos esperar que o modo seja uma categoria flexional de verbos menos frequente que o Tempo e o Aspecto, desde que não afete o significado de um verbo, pois exemplos de expressão lexical de distinções de modos são raros ou não-existentes (BYBEE, 1985, p. 22, 28). 
Os modos caracterizados por uma flexão verbal podem ser analisados sob esses dois critérios:

Modos com:

1. força ilocutória: imperativo, optativo, admonitivo, proibitivo, interrogativo (op. cit., p.170)

2. compromisso com a verdade da asserção: subjuntivo, dubitativo, provável, potencial, condicional.

A partir desses critérios elaborados por Bybee, apresentamos os modos que encontramos em lembaama.

\section{1 O imperativo}

Em lembaama, como em várias línguas, o imperativo é um modo que tem uma grande força ilocutória porque indica uma vontade, uma ordem, um conselho, um desejo etc. A principal característica do imperativo é que ele não expressa de maneira explícita os três sujeitos a que se refere, pois estão todos subentendidos. Entretanto, ele sempre expressa o índice do sujeito (IS). Vejamos este exemplo com o verbo okúná 'plantar'.

Quadro 9: imperativo do verbo okúná 'plantar'

\begin{tabular}{|l|l|l|l|l|l|}
\hline Pessoas & IS & MT & RV & VF & Tradução \\
\hline $2 \mathrm{~s}$ & $\varnothing-$ & $\varnothing-$ & kún- & á & Plante! \\
\hline $1 \mathrm{p}$ & lé- & $\varnothing-$ & kún- & á & Plantemos! \\
\hline 2p & le- & $\varnothing-$ & kún- & á & Plantem! \\
\hline
\end{tabular}

Todas as formas verbais do imperativo têm zero $(\varnothing)$ como marca de tempo, e a vogal final do verbo é a mesma do infinitivo. A segunda pessoa do singular do imperativo (2s) é a pessoa a quem nós nos referimos quando falamos no imperativo. Trata-se da segunda pessoa do singular e seu índice do sujeito é zero. A primeira pessoa do plural do imperativo se refere ao primeiro pronome pessoal do plural (inclusivo) e seu índice do sujeito é lé- (com tom alto). A segunda se refere ao segundo pronome pessoal do plural e seu índice do sujeito é le- (com tom baixo). 


\section{2 O condicional e o Subjuntivo}

O condicional e o subjuntivo são, como vimos, modos que têm um compromisso com a verdade da asserção. Bybee (1985) define o subjuntivo como um termo usualmente aplicado para formas verbais finitas especiais associadas com certos tipos de construções subordinadas. Os usos do subjuntivo variam consideravelmente entre as línguas. Uma língua pode usar o subjuntivo numa situação em que outra usa o indicativo. Na maior parte das vezes, subjuntivos aparecem em certas construções particulares, isto é, ocorrem como complementos de alguns verbos principais, ou depois de algumas conjunções. Quando ocorre depois de alguns verbos, o subjuntivo implica propósito, mesmo se não há conjunções. Na verdade, é difícil determinar o significado do subjuntivo numa dada língua. Há uma vasta literatura em línguas indo-europeias, mas não há uma solução satisfatória. Em geral, se pode dizer que o subjuntivo tem um sentido geral de "não-assertado" e então toma sentidos mais específicos no contexto em que ocorre (BYBEE, 1985, p. 186).

Em lembaama, o que chamamos de condicional é uma forma verbal que apresenta o processo como uma condição ou uma hipótese dentro de um contexto bem definido. $\mathrm{O}$ condicional é sempre seguido de uma outra forma verbal que evoca a consequência da proposição principal. Observamos uma concordância verbal entre essas duas formas. Vejamos um exemplo:

$$
\begin{aligned}
& \text { mvuur' osaweleve, } \\
& \text { mv- uuru o -s- á we le- vé, } \\
& 1 \text { pessoa Inf fazer VF 2s } 9 \text { bem, }
\end{aligned}
$$

\begin{tabular}{|c|c|c|c|c|c|c|}
\hline $\mathrm{w} \varepsilon$ & 0 & $\varnothing$ & -S- & í & ndé & le- \\
\hline $2 s$ & $I S$ & $M T$ & fazer & $V F$ & $2 \mathrm{~s}$ & 9 \\
\hline
\end{tabular}

'Se alguém te fizer o bem,

$$
\text { w’osîndelevé }
$$

'faça-lhe o bem (também)' 
Nesse exemplo, temos duas orações: a primeira ( mvuur' osaweleve 'Se alguém te fizer o bem') expressa uma condição: A segunda (w’osíndelevé‘faça-lhe o bem’) é a consequência. Nem o índice do sujeito nem o tempo são indicados na primeira oração. Na segunda, temos um morfema zero no lugar do morfema de tempo. O verbo tem uma marca de aspecto perfectivo indicado pela vogal final -í. Conforme a definição do subjuntivo, apresentada, pensamos que essa forma verbal da segunda oração (consequência da primeira) seja um subjuntivo porque, de fato, aparece nessa construção particular como consequência da proposição principal.

O condicional se encontra bastante nos provérbios. Vejamos este exemplo:

lekú okisá ggwúrú, alil ’áwí

\begin{tabular}{|c|c|c|c|c|c|c|c|c|c|}
\hline le $-\quad k^{w} u ́$ & ó & -kis- & á & $\varnothing-$ & ngwúrú & a- & lili & a & $-w-$ \\
\hline morte & $\operatorname{Inf}$ & Não encontrar & $V F$ & 1 & mãe & 2 & chorões & IS 2 & acabar \\
\hline
\end{tabular}

'se a morte não encontrasse/encontrar a mãe, não haveria/haverá mais chorões. Isto é, se a mãe não falecesse/falecer, ninguém choraria/chorará'

O exemplo acima é um provérbio. Nele, temos uma condição ou uma hipótese: lekw' okisá ygwúru 'se a morte não encontrasse a mãe', e uma consequência: alil 'áwí 'não haveria mais chorões'. Podemos observar que não há presença de índice de sujeito, nem marca de tempo no primeiro verbo que expressa a condição. Ele permanece no infinitivo. O índice de sujeito (a) e a marca de aspecto perfectivo (a vogal final -í́) só aparecem no segundo verbo, que expressa a consequência. Portanto, em lembaama, a expressão da condição ou da hipótese é feita pelo uso de um infinitivo sem marca de tempo e sem índice de sujeito na oração principal. Assim, a estrutura do condicional é: Sujeito + Infinitivo.

Finalmente, vimos que o subjuntivo aparece, aqui, num contexto bem definido, ou seja, a sua presença é condicionada pelo uso do condicional. Ele não tem estrutura própria porque retoma a marca do perfectivo que é vogal final -í. 


\section{$3.3 \mathrm{O}$ indicativo}

Em lembaama, como em várias outras línguas, o indicativo, como o próprio nome já diz, indica fatos reais e certos ou tidos como tal, seja no presente, seja no passado ou no futuro. Dessa maneira, o indicativo é constituído por todos os tempos descritos anteriormente (cf. Tempo): o presente, o passado recente, o passado distante, o passado remoto, o futuro próximo e o futuro distante.

\section{Conclusão}

Este capítulo apresentou uma análise geral do tempo, aspecto e modo (TAM) em lembaama. Recorremos, quando foi preciso, a estudos de vários autores como Benveniste (1974), Comrie (1985), Costa (2002), Creissels (2006), Castilho (1968), Bybee (1985), Fiorin (1996; 2003), Lyons (1979) e Nurse (2003; 2008). Nurse (2003, p. 90-102 e 2008), que estudou muitas línguas bantas, tem como proposta fundamental que as categorias tempo, modo e aspecto sejam vistas nos termos da linguística geral. Ele conclui que o aspecto é mais fundamental que o tempo. Esse panorama geral, inevitavelmente sincrônico, envolve uma discussão das estruturas e daquilo que pode ser assumido por um estágio inicial do banto. Essa abordagem é baseada no princípio de que o aspecto e o tempo são membros interligados do mesmo sistema. O sistema é destinado ao uso e é também modificado pelo uso. Nurse (2003, p. 102) sugere que futuras investigações úteis sobre aspecto e tempo deveriam focalizar três questões:

1- o que as categorias envolvem ou implicam?

2 - como se combinam no sistema?

3- como são usadas na prática?

Podemos dizer que o ato da enunciação envolve um falante, um espaço (aqui/lá) e um Tempo (agora/então) em qualquer língua. Ao produzir um enunciado, o falante combina morfemas e lexemas que seguem a ordem sintática da língua. Quanto ao sentido do enunciado, ele vai depender do contexto em que será produzido. Isto é, a enunciação não pode ser feita de qualquer forma em qualquer língua. O seu sucesso vai depender de fatores linguísticos e extralinguísticos.

Portanto, concordamos em grande parte com Nurse e destacamos algumas características da morfologia verbal do lembaama relacionadas às categorias de Tempo, Aspecto e Modo. Verificamos que, nessa língua, a codificação do aspecto e do tempo pode ser 
feita pela flexão verbal e pelo uso de verbos auxiliares (como oka 'ficar', odze 'ir', osagha 'procurar', omana 'acabar', etc). Vimos também que é possível ter dois verbos flexionados na mesma oração em lembaama (cf. Passado remoto).

No que diz respeito ao aspecto, descobrimos que lembaama apresenta dois principais aspectos:

i) O perfectivo, marcado pela vogal final -1́, possui geralmente um tom alto. Sua estrutura é: sujeito + índice do sujeito+zero+radical do verbo + vogal final -í.

ii) $\mathrm{O}$ imperfectivo que indica uma ação em andamento e inclui o progressivo - que pode ser expresso pelo verbo - $l i$ 'estar'. Contudo, a tendência hoje é de apagá-lo sem que haja mudança no sentido da oração. Dessa maneira, a oração no progressivo acaba tendo o mesmo sentido da oração no presente e no futuro, que possuem o aspecto imperfectivo. Sua estrutura é:

sujeito+índice do sujeito+zero+(-li)+índice do sujeito+verbo.

O imperfectivo inclui também o habitual, marcado geralmente pelo morfema -ag- no presente e -ig- no passado. Tudo vai depender da vogal final do verbo que forma uma harmonia vocálica e tonal com a vogal do morfema marcador do aspecto. Observamos uma variação manifesta no habitual pela possibilidade de eliminar a consoante velar $\left(-g_{-}\right)$desse morfema, que provoca um alongamento da vogal final, já que apresenta harmonia vocálica e tonal com a vogal da extensão, isto é, identidade, repetição da vogal da extensão. Essa variação, ou instabilidade, se observa mais na fala dos mais jovens. A estrutura do habitual é: sujeito+índice do sujeito+zero+radical $+(\mathrm{Hab})+V F$ alongada

Exceção feita do aspecto imperfectivo, os morfemas de aspecto em lembaama são sempre pospostos ao radical do verbo (ou seja, os aspectos são sempre marcados à direita do radical do verbo). É o caso dos aspectos perfectivo e habitual.

Quanto ao tempo, descobrimos que lembaama tem três tempos principais:

1) Um presente que não tem marcas, e que se confunde com o presente pontual, o progressivo e o futuro. Sua estrutura é:

sujeito+índice do sujeito+radical+vogal final.

2) Dois futuros:

a) Um mais próximo (F1), sem marca, que se confunde com o presente pontual e o progressivo.

b) Outro, mais distante, marcado pelo verbo auxiliar odze 'ir'. Sua estrutura é: sujeito+índice do sujeito+-dze+verbo. 
3) Três passados:

a) Um recente (P1), marcado pelo morfema mí- de tom alto e anteposto ao radical do verbo. Sua estrutura é: sujeito+índice do sujeito+mi+verbo.

b) Um distante (P2), marcado pelo morfema máá- de tom alto, e também anteposto ao radical do verbo. Sua estrutura é: sujeito+índice do sujeito+máá+verbo.

c) Um remoto (P3), expresso pela junção do verbo auxiliar $-k i$ 'estar' (passado de -li) e o morfema do passado recente mi-. Sua estrutura é:

Sujeito+índice do sujeito+-ki+índice do sujeito+mi+-verbo.

Contrariamente aos morfemas de aspectos, os morfemas de tempo são sempre antepostos ao radical do verbo. É o caso dos dois morfemas dos passados recente e distante.

Quanto ao modo, descobrimos três principais modos. São eles:

i) O imperativo: com três pessoas (a segunda do singular, a primeira do plural e a segunda do plural). O índice do sujeito só não aparece no singular. A primeira e a segunda pessoa do plural se distinguem pelo tom - alto na primeira, e baixo na segunda. Sua estrutura é: (índice do sujeito)+verbo.

ii) O condicional aparece bastante nos provérbios e não tem nenhuma marca específica. Sua estrutura é a mais fácil de ser reconhecida: sujeito + verbo no infinitivo. Ele é acompanhado por uma forma verbal que chamamos de subjuntivo, conforme a definição de Bybee (1985). O subjuntivo aparece em contextos bem definidos, mas sem estrutura própria, já que retoma a do perfectivo: a vogal final -í.

iii) O indicativo, que é constituído pelos Tempos citados acima: o presente, o passado e o futuro. Nele, os fatos são tidos como reais ou verdadeiros. 


\section{CONSIDERAÇÕES FINAIS}

O presente trabalho teve como principal objetivo analisar a morfologia verbal do lembaama. Para isso, buscamos primeiro apresentar a estrutura verbal das línguas bantas que usamos como ponto de referência para definir a estrutura verbal do lembaama, uma língua banta da floresta. A análise revelou que a estrutura verbal dessa língua é composta dos seguintes elementos: sujeito, índice do sujeito, negaçãol, marca de Tempo, raiz do verbo, extensão, vogal final ou marca de Aspecto, objeto(s) ou índice do objeto, negação2 que se seguem numa ordem fixa na oração. Observamos que a posição 5 ocupada pelo limitativo na estrutura do protobanto não ocorre na estrutura verbal desta língua. Notamos também que outro fato que difere o lembaama das outras línguas bantas é que essa língua não distingue a posição sufixo ou extensão da pré-final. Constatamos ainda que o índice do objeto, que é geralmente anteposto à raiz do verbo na maioria das línguas bantas (do sudeste da África principalmente), é posposto ao verbo em lembaama. A negação, por sua vez, é representada pelo morfema descontínuo composto por dois elementos: ka- (negação1) e -ní (negação2). Sendo que na estrutura verbal, $k a$ - aparece depois do índice sujeito (à esquerda da raiz do verbo) e - $n i$ aparece depois do índice objeto (à direita da raiz do verbo), é o último elemento da estrutura do verbo.

Em seguida, ao estudar a derivação verbal em lembaama, constatamos ainda que a estrutura das extensões desta língua difere daquela encontrada nas outras línguas bantas pelo fato do lembaama ter acrescentado à estrutura -VC- preexistente no protobanto, estruturas do tipo -C-, -CV- e -CVC-. A extensão mais comum e mais fácil de ser reconhecida nessa língua é aquela que marca o habitual, tanto no presente (-ag-) como no passado (-ig-). Nessa extensão, notamos um apagamento da consoante velar (-g-) que gera o alongamento da vogal final do verbo nos falantes mais jovens, trata-se de um alongamento compensatório que é comum em várias línguas. $\mathrm{O}$ estudo dos sufixos derivativos do lembaama revelou também a existência de uma correlação entre o valor gramatical e o valor semântico das extensões. Dessa maneira, vimos que seres humanos e animados são envolvidos em orações que apresentam uma transitividade alta. $\mathrm{O}$ estudo da transitividade mostrou, ainda, que é uma noção fundamental nessa língua porque distingue ações e estados, por exemplo.

Por último, estudamos as categorias Tempo, Aspecto e Modo (TAM) nessa língua. A análise revelou três tempos principais: um presente que não tem marcas e que se confunde com o presente pontual, o progressivo e o futuro. Dois futuros: um mais próximo, sem marcas, que se confunde com o presente pontual e o progressivo; outro, mais distante, 
marcado pelo verbo auxiliar odze 'ir'. Três passados: um recente, marcado pelo morfema míde tom alto e anteposto ao radical do verbo; um distante, marcado pelo morfema máá- de tom alto e anteposto ao radical do verbo; um remoto, expresso pela junção do verbo auxiliar $-k i$ 'estar' e o morfema do passado mí-. Assim, contrariamente aos morfemas de Aspectos, os morfemas de Tempo são sempre antepostos ao radical do verbo. É o caso dos dois morfemas que marcam os passados recente e distante.

O estudo do Aspecto revelou que os aspectos do lembaama podem ser reduzidos a dois: o perfectivo, marcado pela vogal final -í; o imperfectivo, sem marca específica, que indica uma ação em curso ou não concluída. Nesse sentido, consideramos também o habitual como um aspecto imperfectivo. O habitual revelou-se uma categoria que apresenta elementos morfológicos e semânticos que dizem respeito tanto ao Aspecto quanto ao Tempo. A análise dos tempos e dos aspectos revelou que o Aspecto é mais fundamental em lembaama. No que diz respeito aos modos, descobrimos os três principais. São eles: o imperativo, o condicional e o indicativo.

Finalmente, como este é o primeiro trabalho de descrição sobre a morfologia verbal desta língua, esperamos ter trazido para o debate linguístico fatos novos numa língua banta que até então não tinha sido estudada.

Nosso trabalho não foi exaustivo, pois ainda há muito para estudar nas línguas bantas e no lembaama, em particular, sobre muitos aspectos. Com relação ao verbo, sobretudo, considerando que essas línguas são reconhecidas como "Verby languages", resta descrever com maior profundidade a atuação de fenômenos como tons e focos na estrutura verbal. 


\section{REFERÊNCIAS}

ADAM, J. J. Folklore du haut-ogooué: proverbes, devinettes, fable mbede. Issy-les Moulineaux: Imprimerie Saint-Paul, 1971.

ADAM, J. J.; BITON, A. Dictionnaire ndumu-mbédé-français et français-ndumu-mbédé. Petite flore de la région de Franceville (Gabon), Grammaire ndumu-mbédé. Libreville: Archevéché de Libreville, 1969.

ANDJEMBÉ, Leonard. Le mythe Olendé. Sources, récits, essai de lecture Philosophique. Libreville: Wanda, 1999.

BASTIN, Y. El prefijo locativo de la clase 18 y la expresión del progresivo presente en Bantu (2). In: Estudios Africanos v. 4, n.7, p.61-86, 1989c.

BASTIN, Y.; PIRON, P. Classifications lexicographiques: bantou, bantou et bantoide. De l'intérêt des 'groupes flottants'. In: HOMBERT \& HYMAN (Eds.). Bantu Historical Linguistics: theoretical and empirical perspectives. California, Stanford:CSLI, p. 149$64,1999$.

[Angenot]. Les langues bantoues. In: Inventaire des etudes linguistiques sur les pays d'Afrique noire d'expression française et sur Madagascar, p. 123-186, maps. Daniel Barreteau (ed.). Paris: conseil International de la langue Française, 1978.

BEARTH, T. Sintax. In: NURSE, D.; PHILIPPSON, G. The bantu languages, New York: Routledge, p.121-142, 2003.

BECKETT, H. W. Handbook of Kiluba. Mulongo: Garenganze Evangelical Mission, 1951.

BENNETT, P.R.; STERK, J. P. South Central Niger-Congo: a reclassification, SAL v.8, n.3, p. 241-73, 1977.

BENVENISTE, Emile. Problèmes de lingüistique générale. V.1. Paris: Gallimard, 1966.

Problèmes de lingüistique générale. V.2. Paris: Gallimard, 1974.

BLANCHON, J.; ALIHANGA, M. Notes sur la morfologie du Lempiini de Eyuga. In: Pholia, CRLS, Université Lumière-Lyon2, Lyon, v.7, p. 23-40,1992.

BLANCHON, J. Tone cases. In: BLANCHON, J.; CREISSELS, D. Issues in Bantu Tonology. Köln: Rüdiger Köppe, p.397-412, 1999.

Les classes 9, 10 et 11 dans le groupe bantou (B40). In: Pholia, n.2, p. 5-22, 1987 b. BLEEK, H.W.I. The languages of Mozambique, London: Harrison and Sons, 1856.

A comparative grammar of South African languages. Part I. Phonology, Cape Town and London: J. C. Juta and Trübner \& Co, 1862.

Comparative Grammar of South African Languages. Part 2. The concord. Section 1: The noun, Cape Town and London: J. C. Juta and Trübner \& Co, 1869.

BONVINI, E. Classes d'accord dans les langues négro-africaines.Un trait typologique du Niger-congo, exemple du kasim et du kimbundu. In: Fait de langues, Revue de linguistique, Paris, Ophrys, n.8, p. 77-88, 1996.

BOTNE, R. Future and Distal -ka-'s: Proto-Bantu or Nascent Form(s)? In: HOMBERT \& HYMAN (eds.). Bantu Historical Linguistics: Theoretical and Empirical Perspectives. Stanford: CSLI, p. 473-515,1999. 
BRESNAN, J. \& KANERVA, J. M. Locative inversion in Chichewa: a case study of factorization in gramar, In: Linguistics Inquiry, v. 20, n. 1, p.1-50, 1989. Also forthcoming In: E. Wehrli and T. Stowell, eds., Syntax and Semantics 24: Syntax and the Lexicon, Academic Press, New York.

BYBEE, Joan L. Morphology: a study of the relation between meaning and form. Amsterdam/Philadelphia: John Benjamins Publishing Company, 1985.

BYBEE, J.; PERKINS, R.; PAGLIUCA, W. The evolution of grammar: tense, aspect, and modality in the languages of the world. Chicago: University of Chicago Press, 1994.

CASTILHO, Ataliba. Introdução ao estudo do aspecto verbal na língua portuguesa. Marília, Faculdade de Filosofia, Ciências e Letras, 1968 (Coleção de Teses, 6).

COMRIE, B. Aspect. Cambridge: Cambridge University Press, 1976.

Tense. Cambridge: Cambridge University Press, 1985.

Language universals and linguistics typology. Oxford: Blackwell Publishers, 1989

COSTA, S.B.B. O Aspecto em português. São Paulo: Contexto, 2002.

COUPEZ, A. Étude de la langue Luba. L30. Tervuren: MRAC,1954.

CUNHA, C.; CINTRA, L. Nova gramática do português contemporâneo. $4^{\mathrm{a}}$ ed. revista e ampliada. São Paulo, Lexikon, 2007.

CREISSELS, Denis. Description des langues négro-africaines et théorie syntaxique. Université Stendhal, Grenoble : Ellug, 1991.

Aperçu sur les structures phonologiques des langues négro-africaines. $2^{\text {nd }}$ édition. Grenoble: ELLUG, Université Stendhal,1994.

Conjunctive and disjunctive verb in Tswana. In: South African Journal of African Languages, v.16, n.4, p.109-115,1996.

La problématique du circonstant dans une langue où il existe une forme applicative du verbe (sur l'exemple du tswana)'. In: Rémi, S.; A. Roman (éds.), Le circonstant. Lyon: Presses Universitaires de Lyon, p.115-137, 1998.

Typology. In: HEINE \& NURSE (Eds.). African Languages. Cambridge: Cambridge University Press, p. 231-58, 2000.

La nature hybride de l'infinitif tswana. Lille, 2004. Disponível em <<http://www.ddl.ish-lyon.cnrs.fr/fulltext/Creissels/Creissels2004.pdf >> acesso em: 03 maio 2010.

Syntaxe générale: une introduction typologique - v.1, Catégories et constructions. Cachan: Germes - Lavoisier, 2006.

Syntaxe générale: une introduction typologique - v.2, la phrase . Cachan: Germes Lavoisier, 2006.

DIMMENDAAL, G. J. Morphology. In: HEINE \& NURSE (Eds.). African Languages. Cambridge: Cambridge University Press, p. 161-193, 2000.

DIXON, ROBERT M. W. Ergativity. In: Language, n.55, New York: Linguistic Society of America, p.59-138,1979.

DOKE, C. M. Bantu Linguistics Terminology. London: Longmans and Green, 1935.

DUBOIS, J. et al. Dictionnaire de Linguistique. Librairie Larousse, Paris: 1973. 
DUBOIS, J. et al. Dicionário de Linguística. Tradução dirigida e cordenada por Izidoro Blikstein. São Paulo: Cltrix, 2006.

FIORIN, J. L. As Astúcias da Enunciação - As categorias de pessoa, espaço e tempo. São Paulo: Ática, 1996.

Introdução à Linguística II. Princípios de análise. São Paulo: Contexto, p.161-185, 2003.

GREENBERG, J. H. Vowel and nasal harmony in Bantu languages. In: Revue Congolaise/Zaïre, n.5, p.813-20,1951.

Some universals of grammar with particular reference to the order of meaningful elements. In GREENBERG, J. H.(ed.). Universals of language, $2^{\text {nd }}$ ed. Cambridge, MA: MIT Press, 1963b.

The languages of Africa. The Hague: Mouton, 1963a

The languages of Africa. The Hague: Mouton \& Co, 1966.

How does a language acquire gender markers? In: GREENBERG (Ed.). Universals of human language: Word structure, v.3. Stanford University Press, v. 3, p. 47-82 1978a, $1978 b$.

GRÉGOIRE, C. The Bantu languages of the forest. In NURSE, D.; PHILIPPSON, G. The bantu languages, New York: Routledge, p. 349-370, 2003.

GUARISMA, G. kpā? (A53). In: NURSE, D.; PHILIPPSON, G. The bantu languages, New York: Routledge, p.307-334, 2003.

GUILlAUME, G. Temps et verbes. Paris : Champion, 1968.

GÜLDEMANN, T. The genesis of verbal negation in Bantu and its dependency on functional features and clause types. In: HOMBERT and HYMAN (eds.). Bantu Historical Linguistics: Theoretical and Empirical Perspectives. Stanford: CSLI, p. 545-87, 1999.

GUTHRIE, M. The classification of the Bantu Languages. London : International African Institute (IAI), 1948.

The classification of bantu languages. London: IAI, 1953.

Comparative Bantu: an introduction to the comparative linguistics and prehistory of the bantu languages. Farnborough: Gregg Press, 1967-71. 4v.

Comparative Bantu. Farnborough: Gregg Press, 1971. v.2.

HEINE, B. A Tipology of African languages based on the order of meaningful elements. Berlin: Dietrich Reimer, 1976.

HEINE, B.; VOBEN, R. Sprachtypologie. In: HEINE, SCHADEBERG, WOLFF (Ed.). Die Sprachen Afrikas. Hamburg: Buske, p. 407-44,1981.

HEINE, B. et al. Conceptual shift, a lexicon of grammaticalization processes in African languages. In: Afrikanistische Arbeitspapiere (AAP), v. 34, n.5, 1993.

HEINE, B.; NURSE, D. African Languages. Cambridge: Cambridge University Press, 2000.

HOPPER, P.J.; THOMPSON, S.A. Transitivity in Grammar and Discourse. In: Language, New York: Linguistic Society of America, v.56, n.2, p. 251-299,1980. 
HYMAN, L. M. Phonology and noun structure. In: HYMAN (Ed.). Aghem Grammatical structure. SCOPIL, n.7, p. 1-72,1979.

HYMAN, L. M. Relative time reference in the Bamileke tense system. In: Studies in African Languages $(S A L)$, v. 11, n. 2, p. 227-237, 1980.

HYMAN, L.; WATTERS, J. R. Auxiliary Focus. In: SAL, v.15, p. 233-73, 1984.

HYMAN, L. M. Suffix ordering in Bantu: a morphocentric approach. In G. E. Booij (ed.), Yearbook of Morphology. London: Dordrecht Kluwer, p. 245-82, 2002.

JOHNSTON, H. H. A comparative study of the Bantu and Semi-Bantu languages. Oxford: Clarendon Press, 1919-22. 2 v.

KAMANDA, K. Éléments de description du zamba, langue bantoue (C31e) du Zaïre. Mémoire. Brussels : Université libre de Brussels, 1991.

KAMBA MUZENGA, J. G. Les formes négatives dans les langues bantoues. Tervuren: Koninklijk Museum voor Midden-Africa, 1981.

KATAMBA, F. Bantu nominal morphology. In: NURSE, D.; PHILIPPSON, G. The bantu languages, New York: Routledge, p. 103-120, 2003.

KUTSCH LOJENGA, C. Kibudu: a bantu language with nine vowels. In: Africana Linguistica, Tervuren: n.9, p.127-34,1994a.

The vowel system of Bila: a Bantu language of the northern Bantu borderland in Zaire. Leiden, 1994b.

LEWIS, M. Paul. Ethnologue: Languages of the World, sixteenth edition. Dallas: Summer Institute of Linguistics (SIL), 2009. Disponível em $<$ http://www.ethnologue.com $\gg$, acesso em: 11 de junho de 2010.

LYONS, J. Introdução à Linguística Teórica. [Introduction to Theoretical Linguistics]. Tradução de Rosa Virgínia Mattos e Hélio Pimentel. São Paulo: Editora Nacional/EDUSP, 1979.

MAHO, J. A classification of the Bantu languages: an update of Guthrie's referential system. In: NURSE, D.; PHILIPPSON, G. The bantu languages, New York: Routledge, p.639-651, 2003.

MANN, M., DALBY, D. et al. A thesaurus of African languages, London: Hans Zell Publishers. 1987.

MARCHAL-NASSE, C. Esquisse de la langue tsogo: phonologie et morphologie. Mémoire. Université Libre de Bruxelles, 1979.

De la phonologie à la morphologie du nzébi, langue bantoue (B52) Du Gabon. PhD thesis. Brussels: Université Libre de Bruxelles, 1989.

MEINHOF, C. Grundriss einer Lautlehre der Bantusprachen, Leipzig: F. A. Brockhaus. Revised edition 1910, Berlin: Dietrich Reimer, 1899.

Das verbum in der Isubu-Sprache. In: Zentrum für Allgemeine Sprachwissenschaft (ZAS), Typologie + Universalienforschung. 3. A23. Berlin, p. 206-34, 1889-90a.

Das Zeitwort in der Benga-Sprache. In : ZAS 3. A34, p. 265-84,1889-90b.

Die Sprache der Herero in Deutsch Südwestafrika. R31. Berlin, 1906a. 
Linguistische ..., 8. Bondie, 9. Zigula. Mitteilungen des Seminars für Orientalische Sprachen(MSOS), 1906b.

Grundzüge einer vergleichenden Grammatik der Bantusprachen, Berlin: Dietrich Reimer. Revised edition 1948, Hamburg : Von Eckardt and Messtorff, 1906.

MEINHOF, C. ; VAN WARMELO, N. J. Introduction to the phonology of the Bantu languages. Berlin: Dietrich Reimer, 1932.

MEEUSSEN, A. E. 'Essai de Grammaire Rundi', in Annales du Musée Royal du Congo Belge, Séries Sciences Humaines, Linguistique, vol. 24, Tervuren : MRAC. D62, 1959.

Bantu grammatical reconstructions. Africana Linguistica III, $\mathrm{n}^{\circ}$ 61. Tervuren: Musée Royal de l'Afrique Central. 1967.79-121.

Bantu lexical reconstructions, Tervuren: MRCA [reprinted in 1980], 1969.

MOTINGEA MANGULU, A. Étude comparative des langues Ngiri de l'entre UbangiZaire. Leiden: Center for non-Western Studies (CNWS), 1996.

NGUNGA, A . Introdução à lingüística bantu. Maputo: Universidade Eduardo Mondlane, Imprensa Universitária. 2004.

NICHOLS, J. Linguistic diversity in time and space. Chicago and London: University of Chicago Press, 1992.

NSUKA NKUTSI, F. Les structures du relatif dans les langues bantoues, Tervuren: MRAC, Annales Sciences Humaines 108, 1982.

NURSE, D. Classification of Sample Bantu Languages of Tanzania. E, F, G, (J), M, P. AL/AL5, n.1, p.1-150, 1979a.

NURSE, D. ; PHILIPPSON, G. The Bantu Languages. New York: Routledge. 2003.

NURSE, D. Tense and Aspect in Bantu. New York: Oxford University Press. 2008.

OKOUDOWA, B. Descrição preliminar de aspectos da fonologia e da morfologia do lembaama, 2005. 102p. Dissertação (Mestrado em Linguística) - Faculdade de Filosofia, Letras e Ciências Humanas, Universidade de São Paulo, São Paulo.

PEDRO, José Domingo. Étude grammaticale du kimbundu (Angola),1993. Thèse (Doctorat en sciences du langage), Université René Descartes, Sorbonne, Paris.

SCHADEBERG, T. C. Derivation. In NURSE, D.; PHILIPPSON, G. The bantu languages, New York: Routledge, p.71-89, 2003.

Spirantization and the 7-to-5 vowel merger in Bantu, in M. Dominicy and D. Demolin (eds) sound Change (Belgian Journal of Linguistics 9), Amsterdam: John Benjamins, 1994-5. 73-84.

A Sketch of Umbundu. Cologne: Rüdiger Köppe Verlag (RKV), R11,1990a.

Schon-noch-nicht-mehr: das Unerwartete als grammatische Kategorie im Swahili. G42. Frankfurt: Frankfurter afrikanische Blätter (FAB) 2, p. 1-15,1990b.

La morphologie verbale du Bantu commun et les langues bantoues du Cameroun. In:

L'expension bantoue. Viviers, p.503-509,1980.

TIMBERLAKE, A. Hierarchies in the genitive of negation. In Slavic and East European Journal, n.19, p. 123-38,1975.

Reanalysis and actualization in syntactic change. In: Li, p.141-77,1977. 
TWILINGIYIMANA, C. Éléments de description du doko, Tervuren: MRAC Annales Sciences 116, 1984.

WILLIAMSON, K.; BLENCH, R. M. Niger-Congo. In: HEINE and NURSE (Eds.). African Languages: An introduction. Cambridge University Press. Cambridge, p. 1-41, 2000.

WILLIAMSON, K. Niger-Congo overview. In: Bendor-Samuel (ed.). The Niger-Congo languages: a classification and description of Africa's largest language family. Lanhan:University of America, p. 3-45, 1989a.

Benue-Congo overview. In: Bendor-Samuel (ed.). The Niger-Congo languages: a classification and description of Africa's largest language family. Lanhan:University of America, p. 247-274, 1989b.

WATTERS, J. R. Syntax. In: Heine et al. African Languages: An introduction. Cambridge University Press. Cambridge, p.194-230, 2000.

XAVIER, M., \& M.H.Mateus (orgs). Dicionário de Termos Lingüísticos. Lisboa: Edições Cosmos. 1992.

YUKAWA, Y. A tonological study of Luvale verbs. In: YUKAWA (Ed.). Bantu Linguistics: Studies in Zambian Languages. Tokyo: ILCAA, v.1, p. 1-33,1987b. 
APÊNDICES 


\section{O CORPUS}

Apresentamos, abaixo, o corpus que usamos para a elaboração deste trabalho. Ele é composto de uma lista de verbos que, em parte, tiramos da nossa dissertação de Mestrado (OKOUDOWA, 2005, p. 75); de uma lista de provérbios contendo verbos na sua maioria, extraídos da obra do arcebispo J.J.Adam (1971, p. 11-357). Como este trabalho registra mais de quinhentos provérbios e mais de oitenta contos e/ou fábulas nessa obra, selecionamos alguns para este estudo.

Diferentemente do trabalho de Adam, nosso trabalho é foneticamente transcrito com anotações de tons e indicação de algumas elisões pelo sinal do apóstrofo. Por outro lado, fizemos uma transcrição fonológica das consoantes labializadas e palatalizadas. O alfabeto usado para as transcrições é o fonético internacional de 1993, corrigido em 1996.

1-Verbos: apresentamos, a seguir, os verbos que foram objeto da nossa análise, separados em diferentes grupos, pelo critério da transitividade.

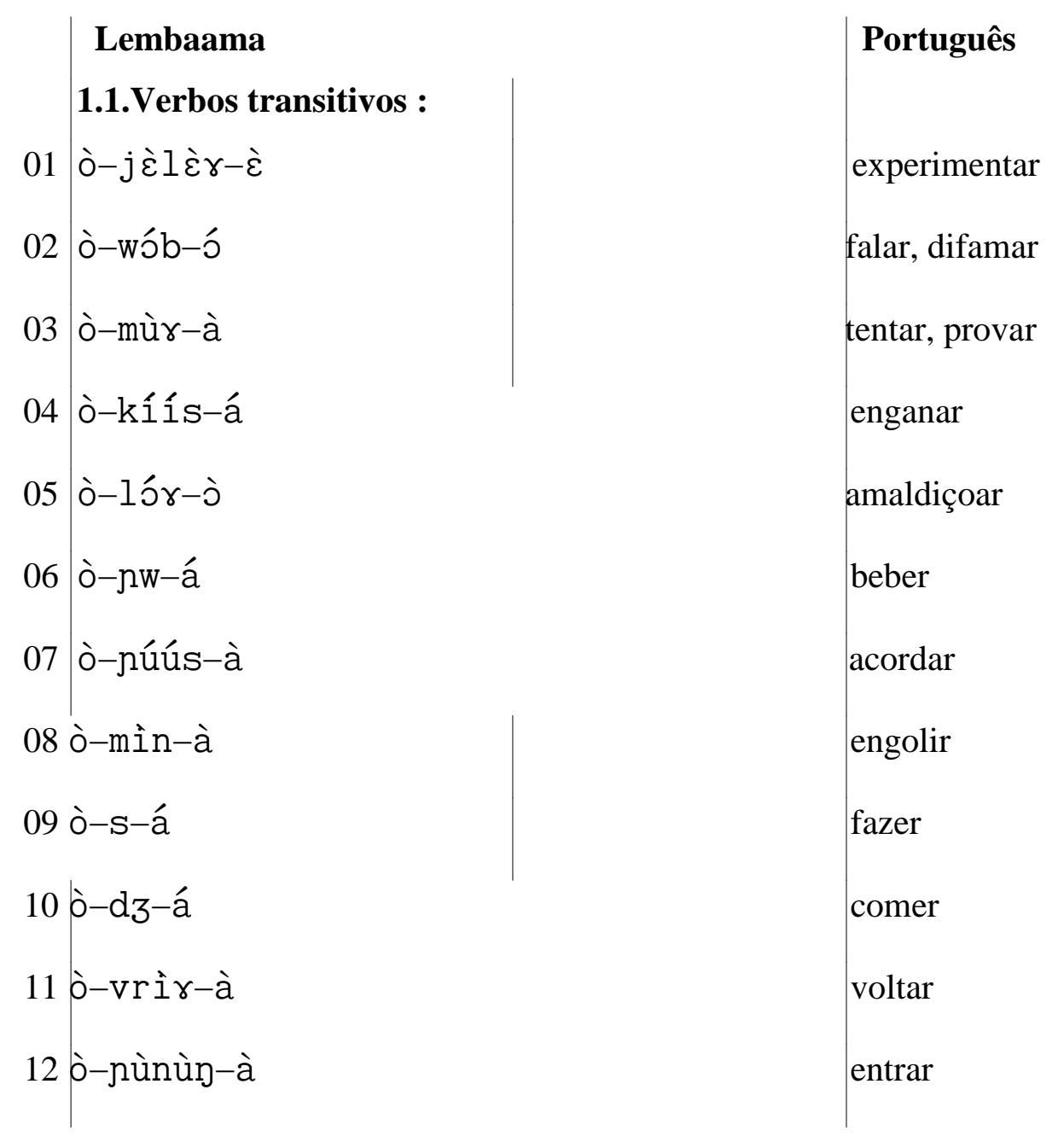




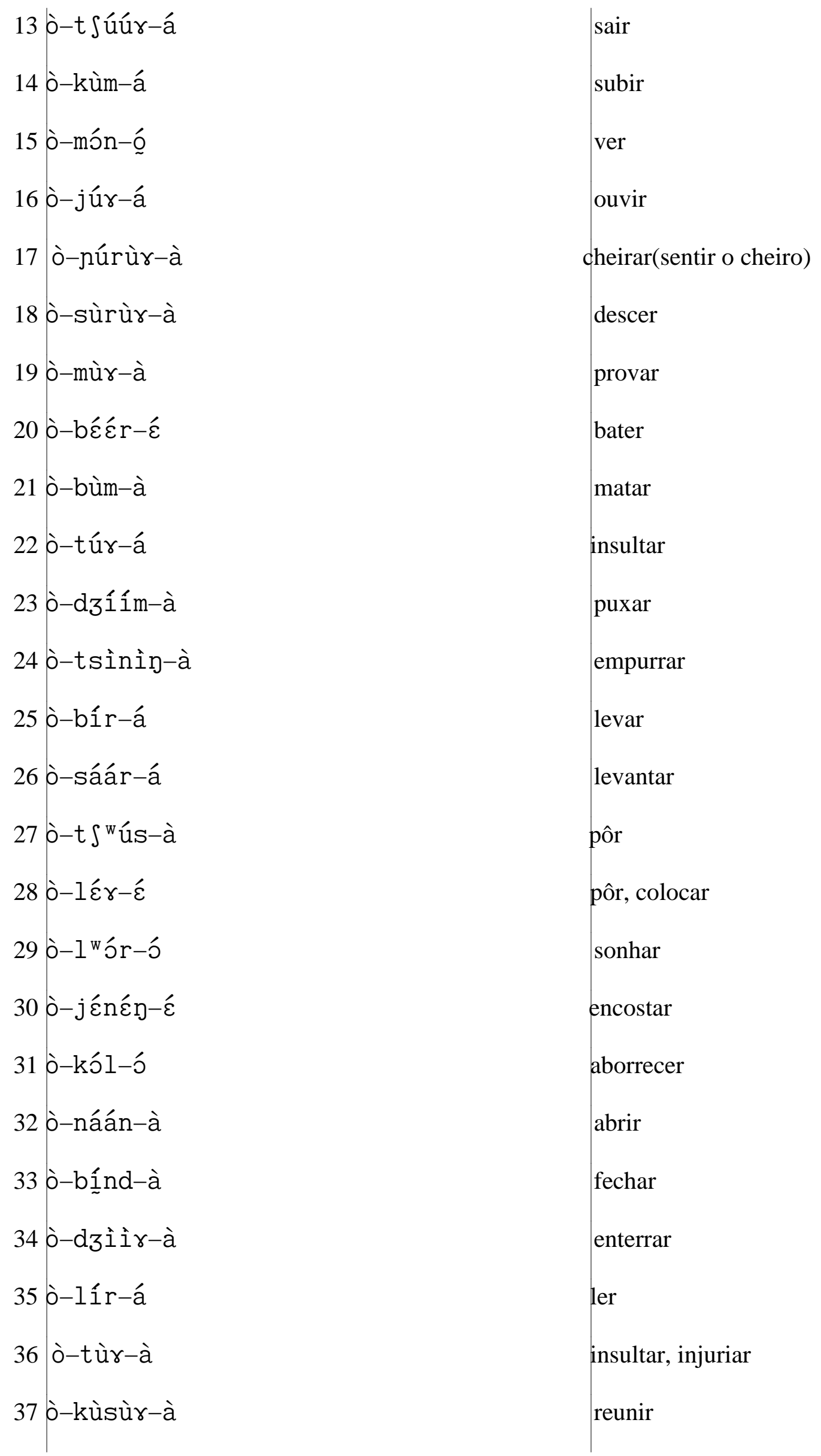




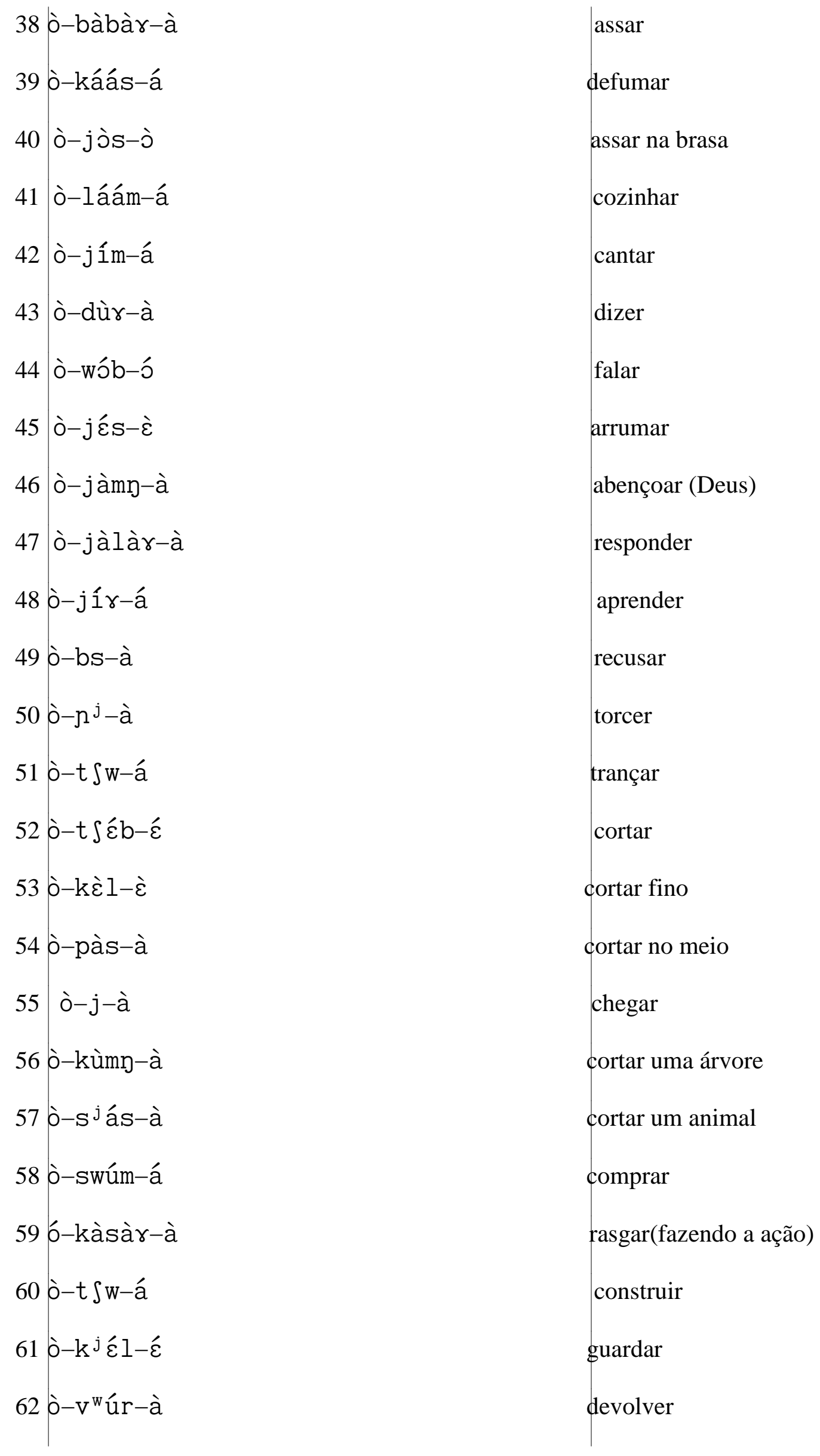




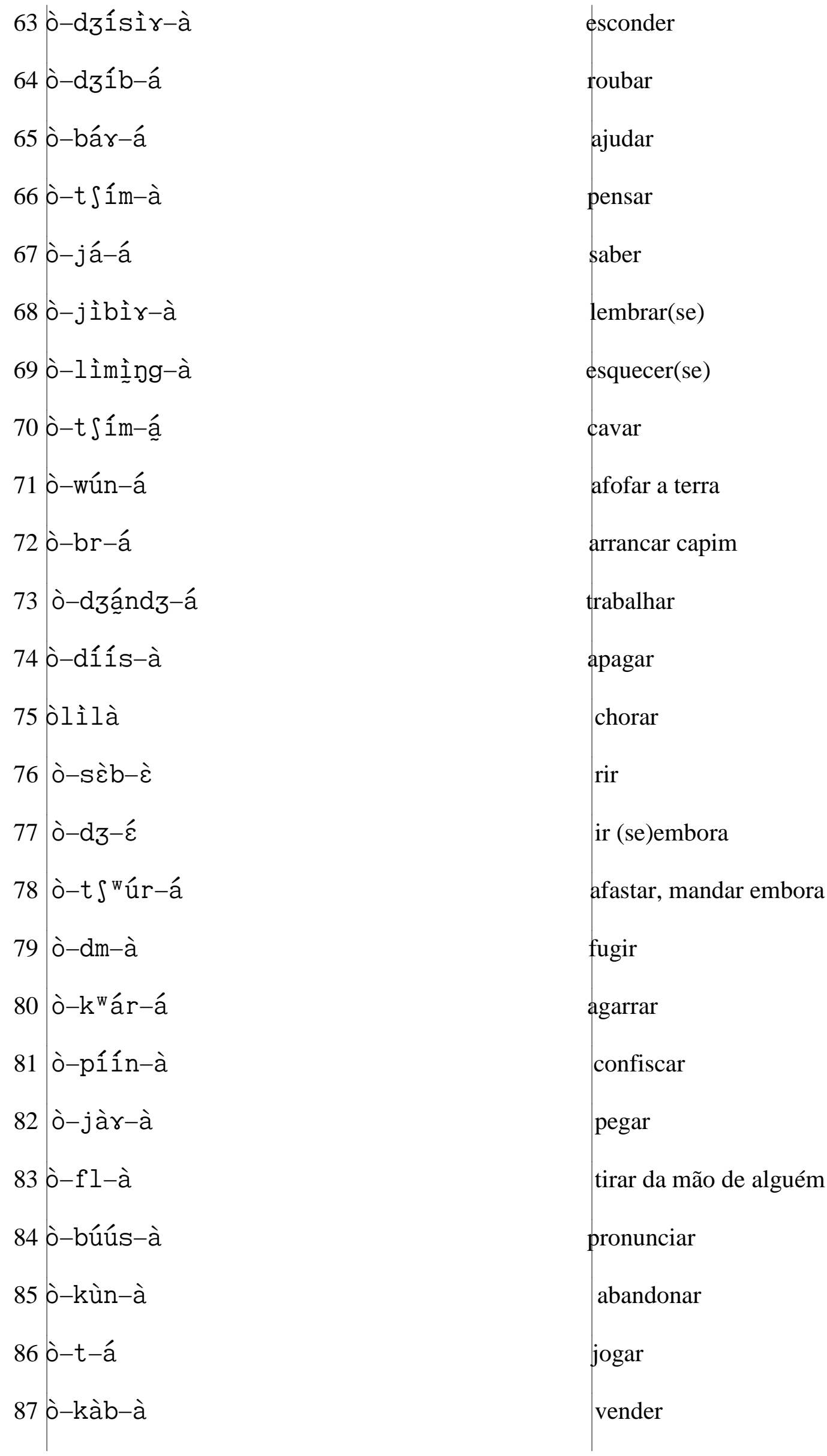




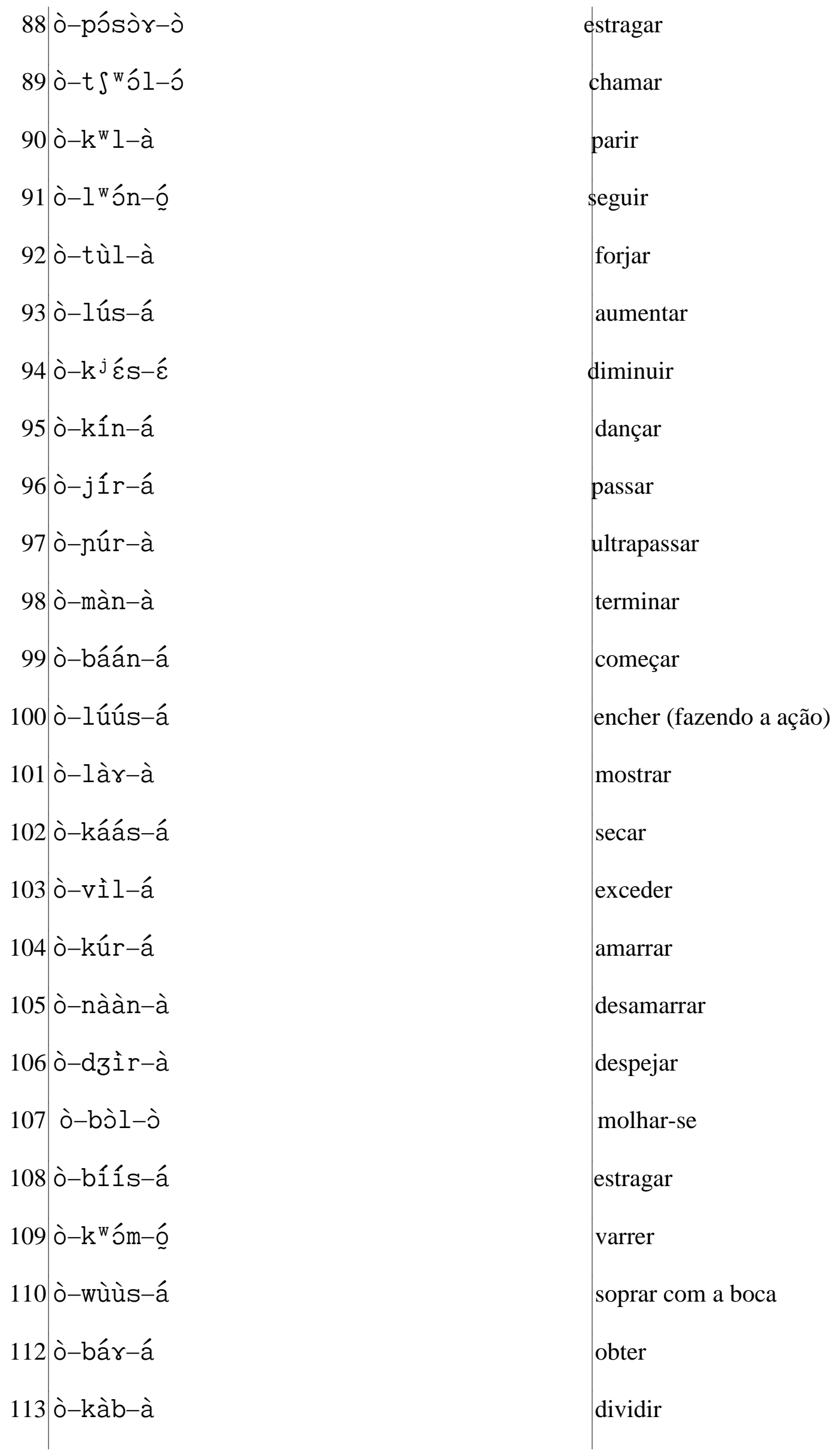




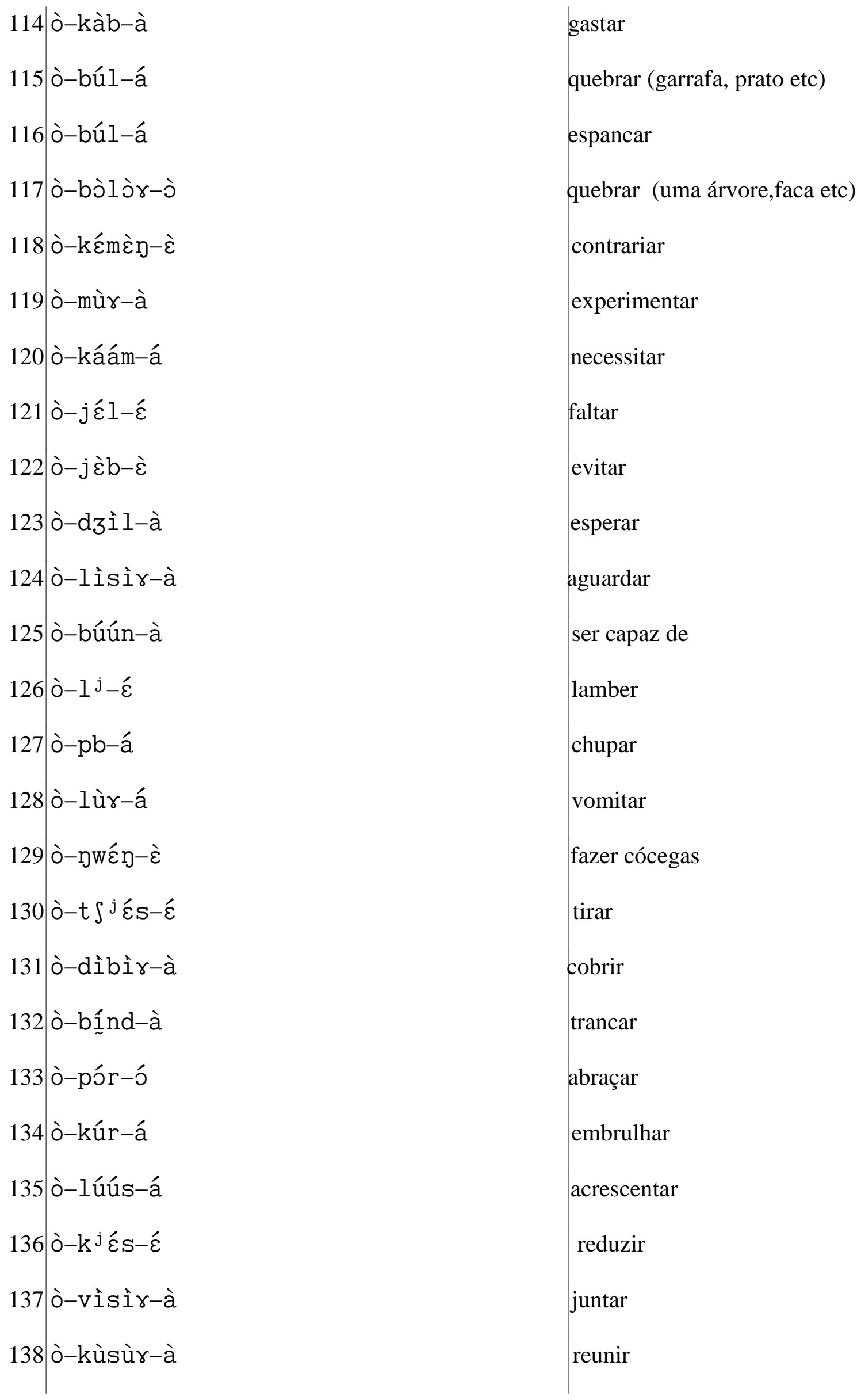




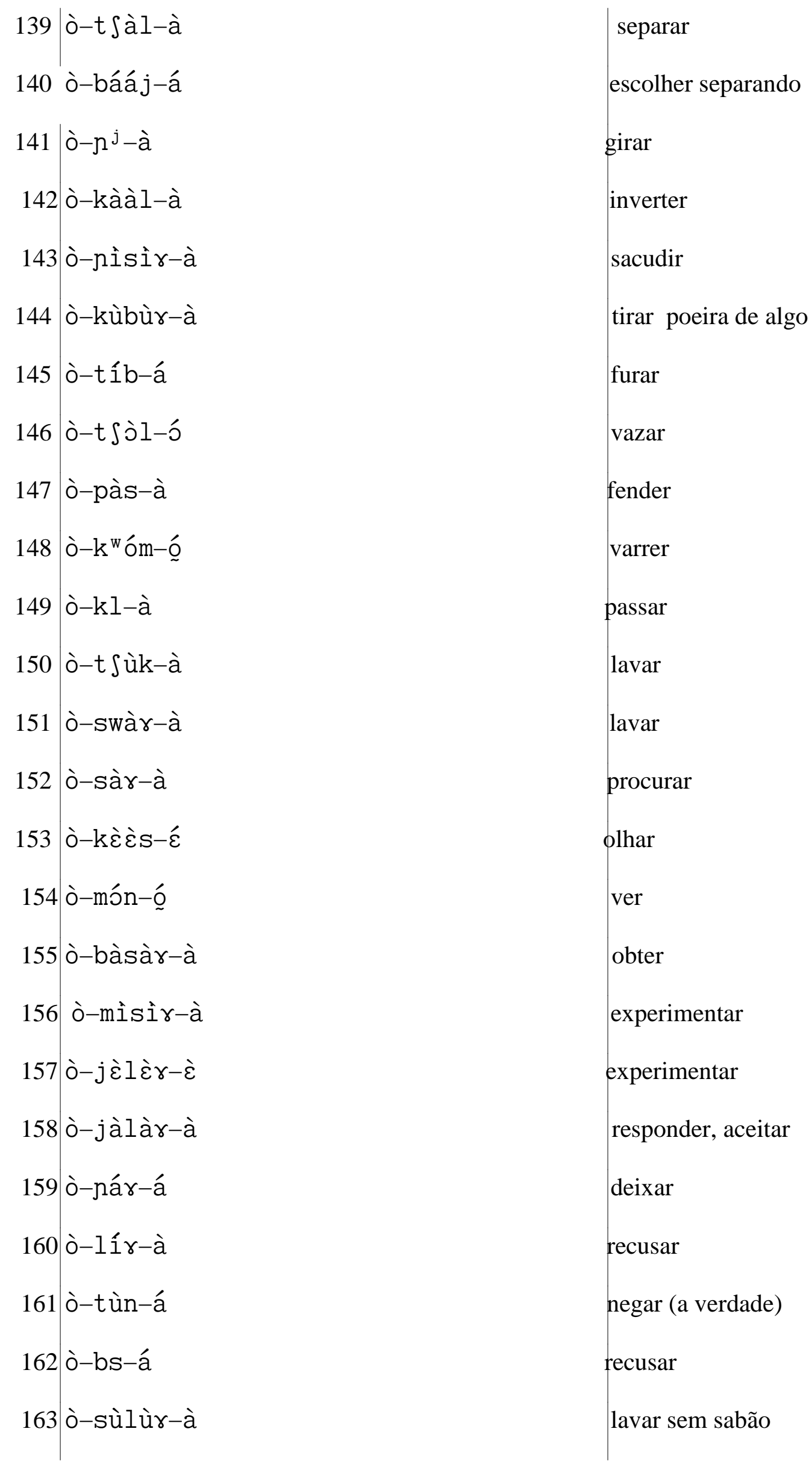




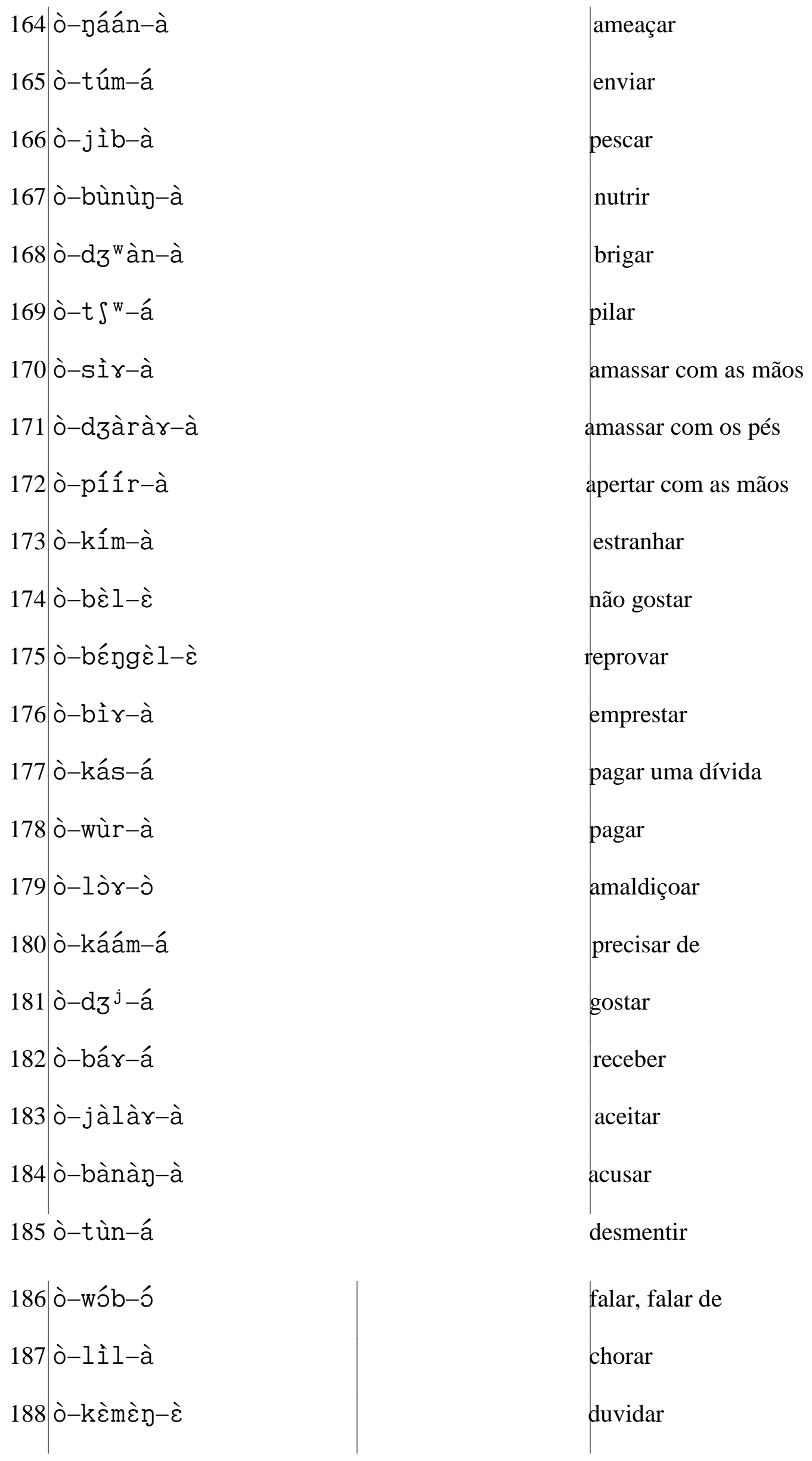




$$
\begin{aligned}
& 189 \text { ò-júr-á } \\
& 190 \text { ò-júsùr-à } \\
& 191 \text { ò-sàr-à } \\
& 192 \text { ò-dzî́b-á } \\
& 193 \text { ò-vwúl-á } \\
& 194 \text { ò-k j }-a ̀ \\
& 195 \text { ò-nùr-à } \\
& 196 \text { ò-nớn-ò } \\
& 197 \text { ò-jór-ó } \\
& 198 \text { ò-j jèn غ̀n-غ̀ } \\
& 199 \text { ò-kîî́s-á } \\
& 200 \text { ò-kúr-á } \\
& 201 \text { ò-bír-á } \\
& 202 \text { ò-bìr-á } \\
& 203 \text { ò-tîn-á } \\
& 204 \text { ò-làmìn-à } \\
& 205 \text { ò-p } \mathrm{p}^{j}-\mathrm{a} \\
& 206 \text { ò-sàlàr-à } \\
& 207 \text { ò-n-á } \\
& 208 \text { ò-lààs-à } \\
& 209 \text { ò-láás-á } \\
& 210 \text { ò-káál-à } \\
& 211 \text { ò-t-á } \\
& 212 \text { ò-fùr-à } \\
& 213 \text { ò-bùnùn-à }
\end{aligned}
$$

entender 


$$
\begin{aligned}
& 214 \text { ò-t Sàl-à } \\
& 215 \text { ò-náán-à } \\
& 216 \text { ò-t } \int^{j} \varepsilon s-\varepsilon \\
& 217 \text { ò-bààn-à } \\
& 218 \text { ò-br-á } \\
& 219 \text { ò-bî́ís-á } \\
& 220 \text { ò-t Sàl-à } \\
& 226 \text { ò-d3 jà } \\
& 227 \text { ò-kwól-à } \\
& 228 \text { ò-wùbùr-à } \\
& 229 \text { ò-wùr-á } \\
& 230 \text { ò-wr-à } \\
& 231 \text { ò-wùrùr-à } \\
& 232 \text { ò-swól-ó } \\
& 233 \text { ò-bááj-á } \\
& 234 \text { ò-swว̀l-ò } \\
& 235 \text { ò-fùr-à } \\
& 236 \text { ò-d3ìr-à } \\
& 237 \text { ò-Sغ̀l } \mathrm{\varepsilon} \gamma-\grave{\varepsilon} \\
& 238 \text { ò-vìsìr-à } \\
& 239 \text { ò-nààs-à } \\
& 240 \text { ò-dî́ís-á } \\
& 241 \text { ò-dîís-á } \\
& 242 \text { ò-sìb-à } \\
& 243 \text { ò-kún-á }
\end{aligned}
$$

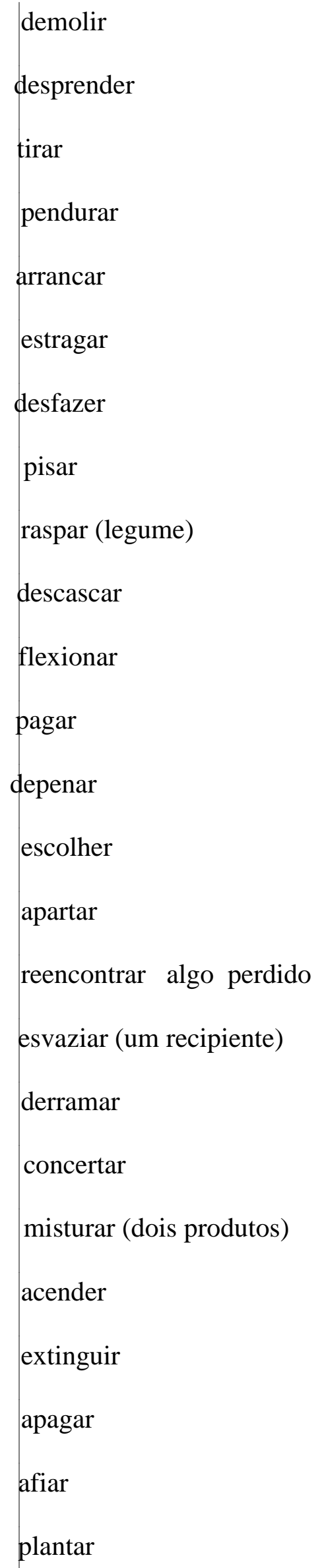




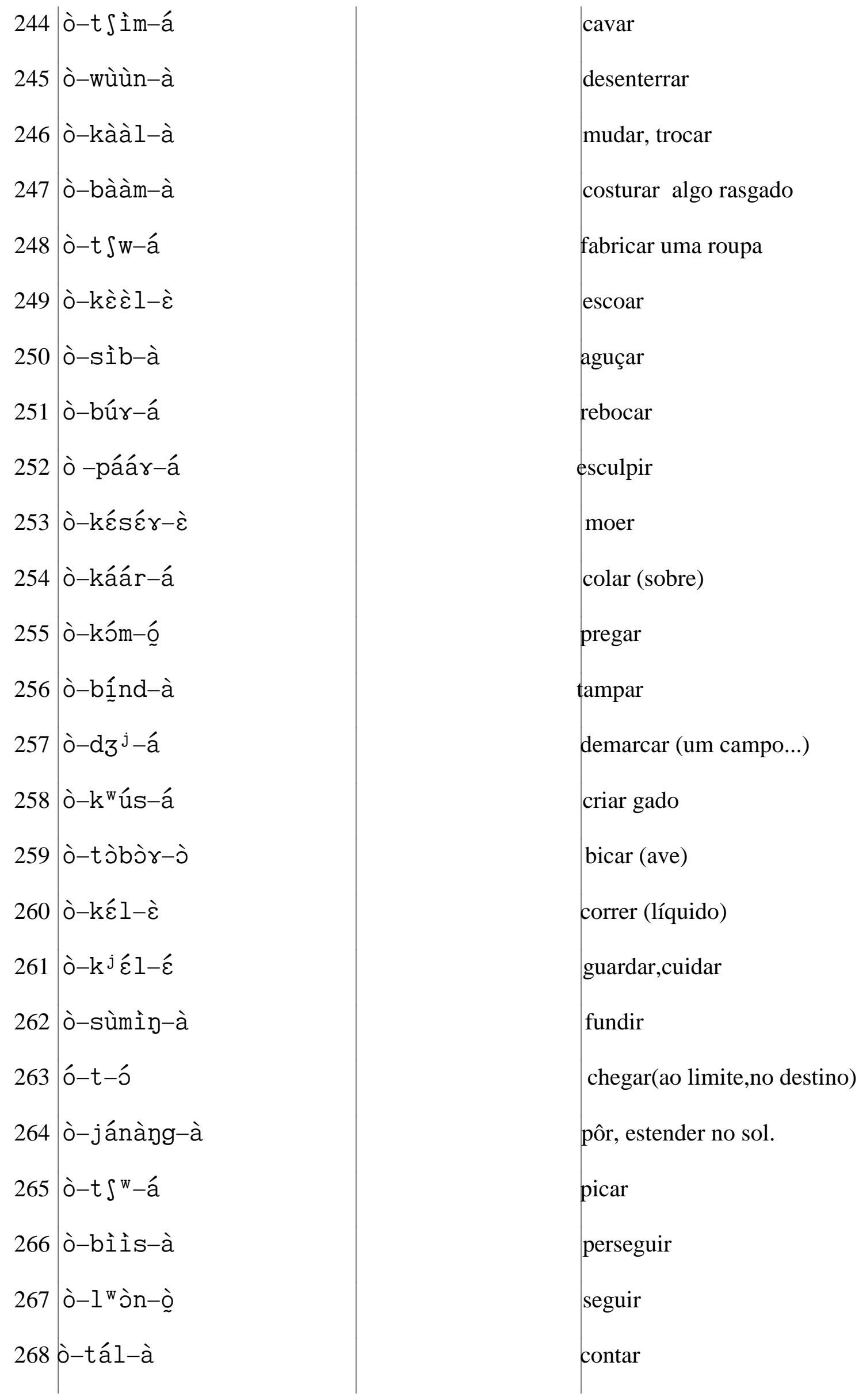




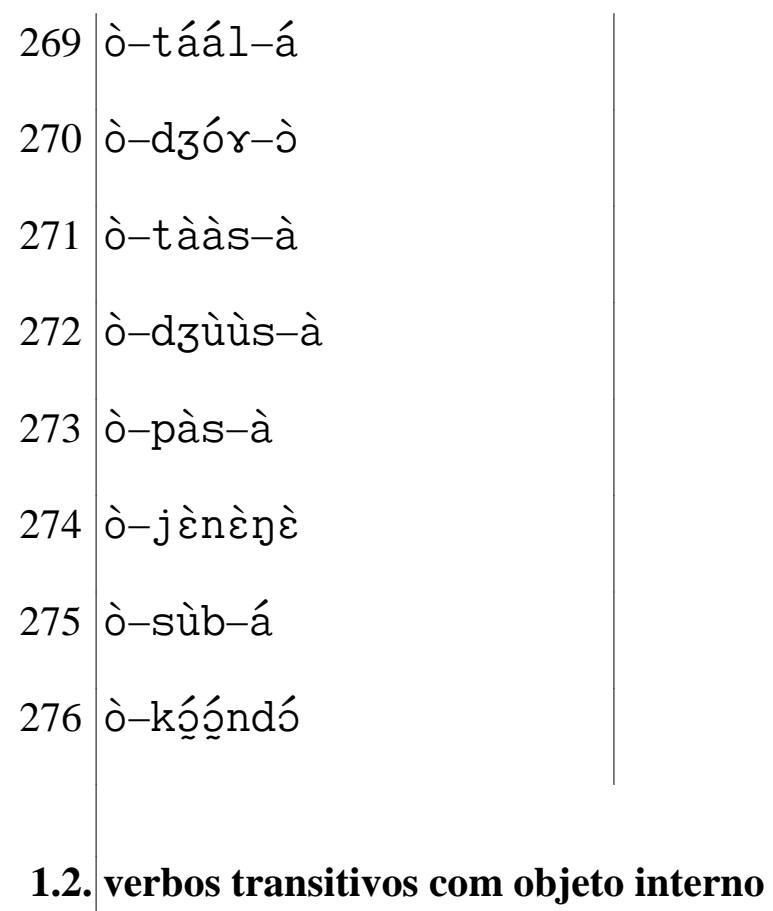

\subsection{1. com substantivo}

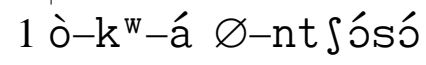
morrer $8^{33}$ - razão

2 ò-bár-á Ø-ntsósó ganhar 8- razão

3 ò-ts-á Ø-tóló dormir 9- sono

4 ò-t $\int-a ́$-mpììí dormir 7-noite

5 ò-ts-á ò-mfí dormir 11-relação sexual

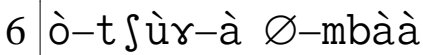
queimar 7-fogo

7 ò - $\mathrm{V}^{\mathrm{w}}-\mathrm{à} \quad \varnothing-\mathrm{mbàà}$ queimar-se 7-fogo

8 ò-láás-á à-mfá vestir 8-roupas

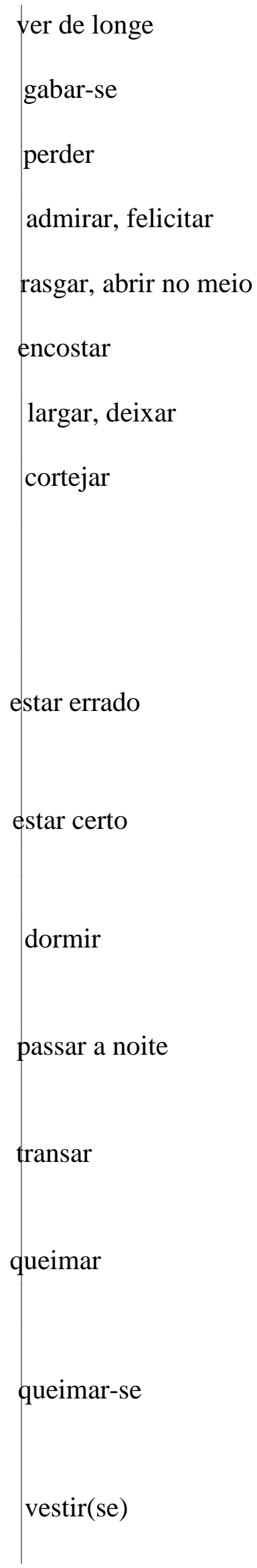

${ }^{33}$ Os números correspondem à classe nominal do substantivo. 


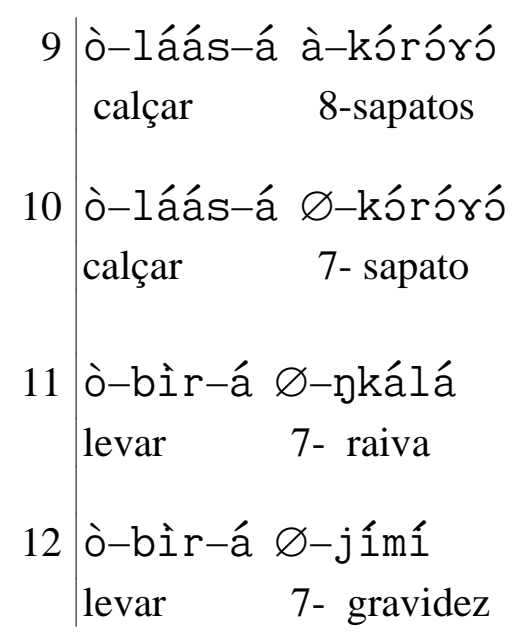

13 ò-bjò̀ $\quad \varnothing-n k a ́ l a ́$

$14 \mid$ ò-mp-á á-bómó

dar 8-dotes

15 ò-bér-é $\varnothing-m f^{a} a$

bater 7-roupa

16 ò-t $\int w-a ́$ m̀-fú

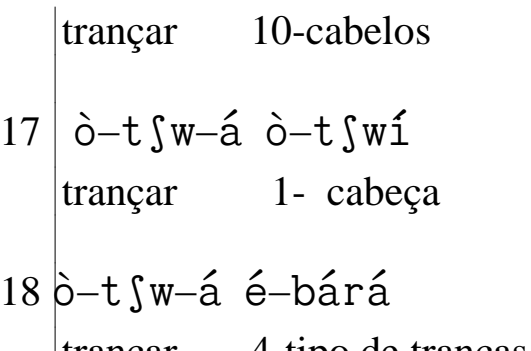

19 ò-t $\int w-a ́$ trançar $\varnothing-d$-tipo de tranças

d9-tsw-á

construir 7-casa

20 ò-nw-á $\varnothing-b^{j} \varepsilon ́ 1 \varepsilon$

beber 7- seio

21 ò-nw-á à-bjélé

beber 8-seios

22 ò-nw-á lé-káá

beber 9- tabaco

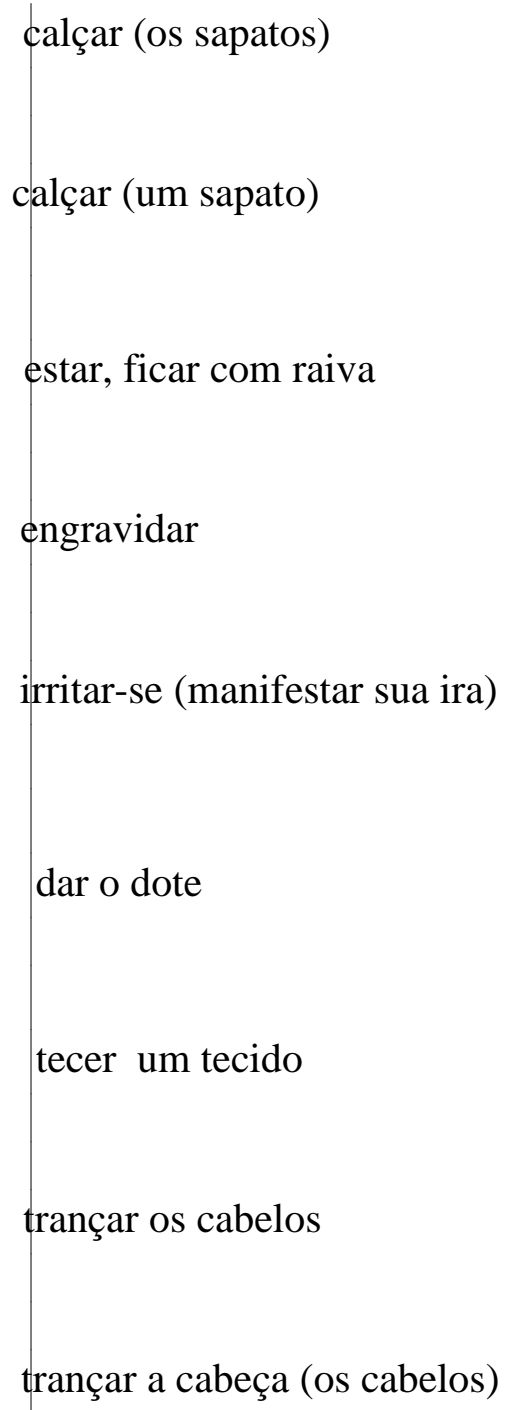




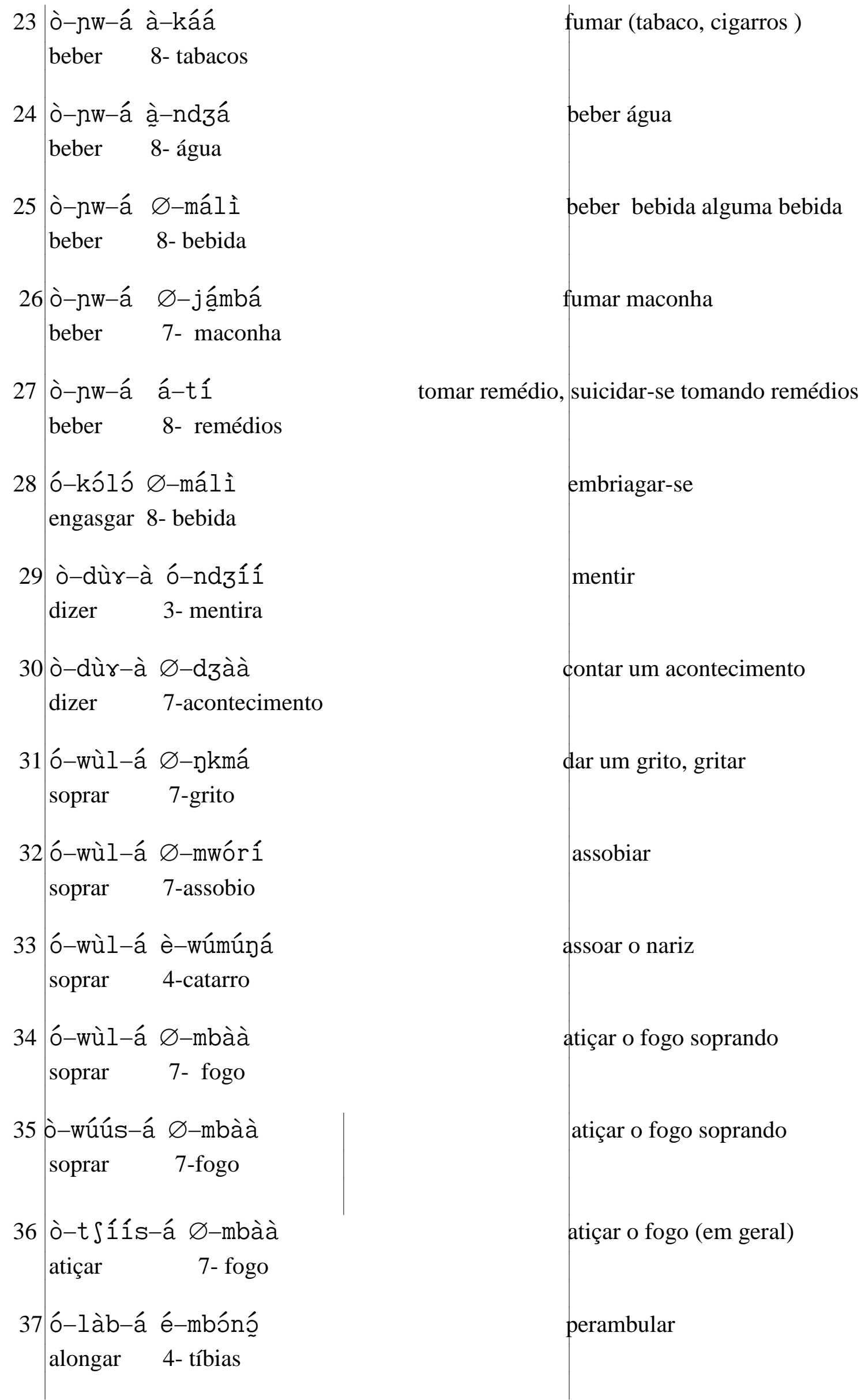




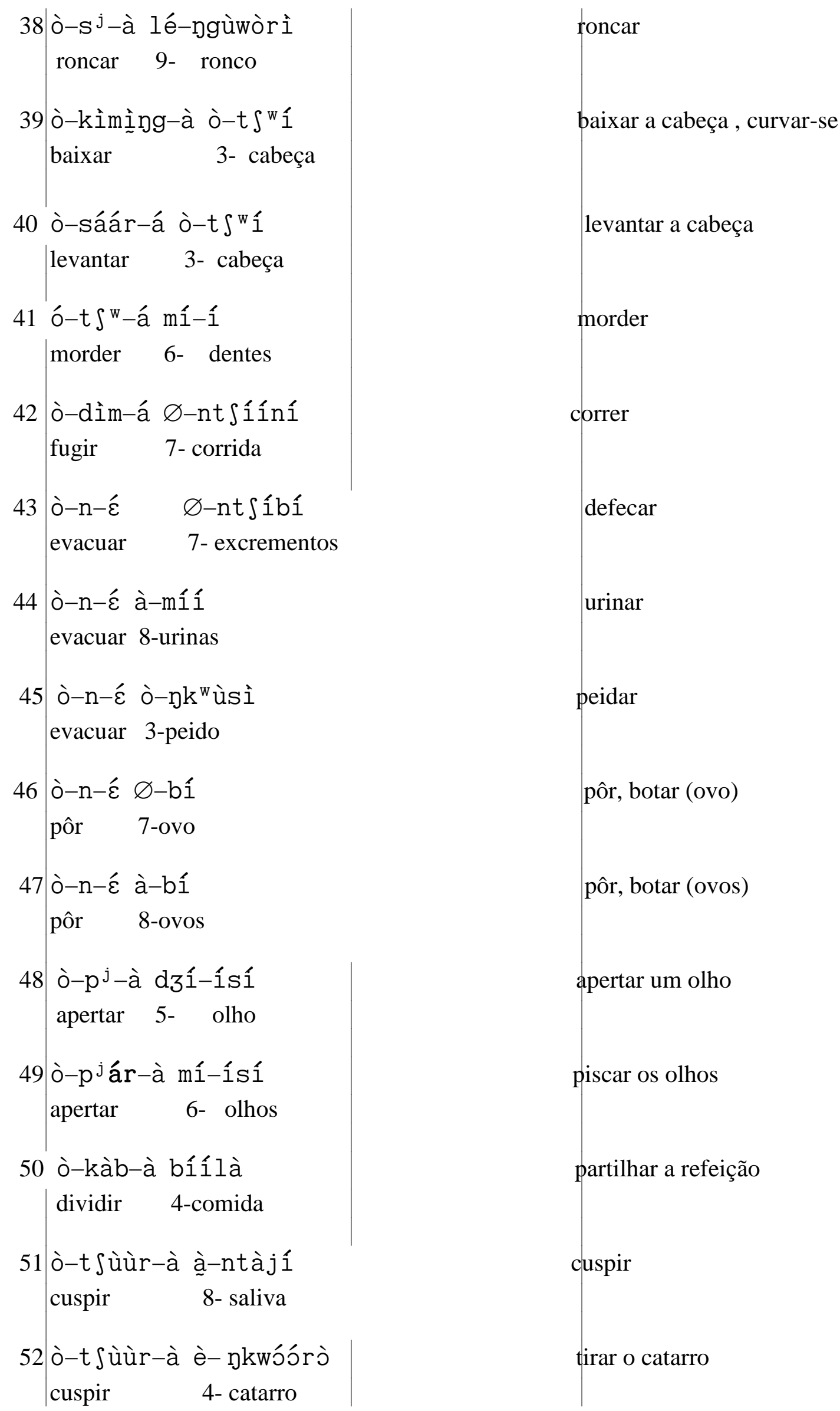




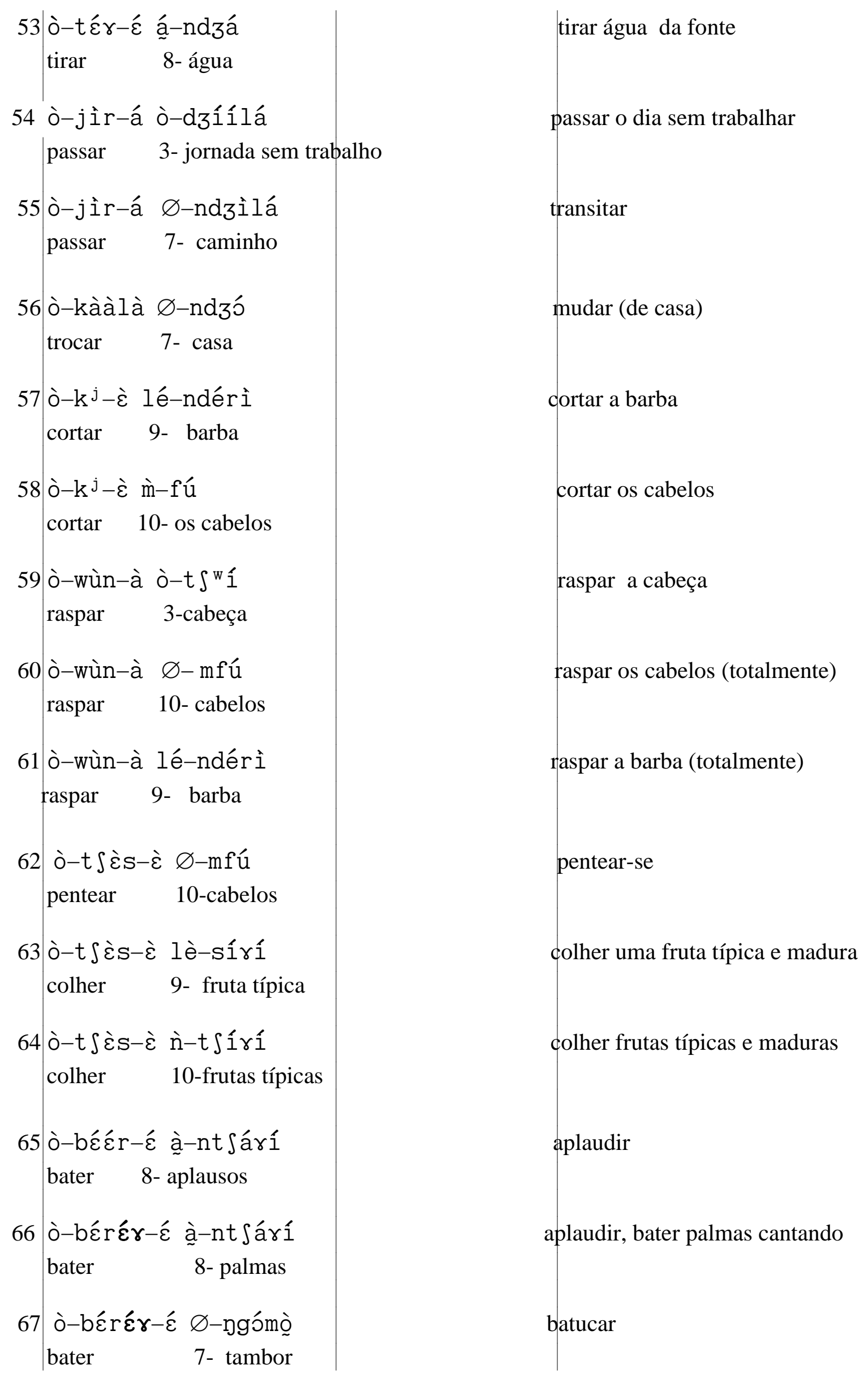




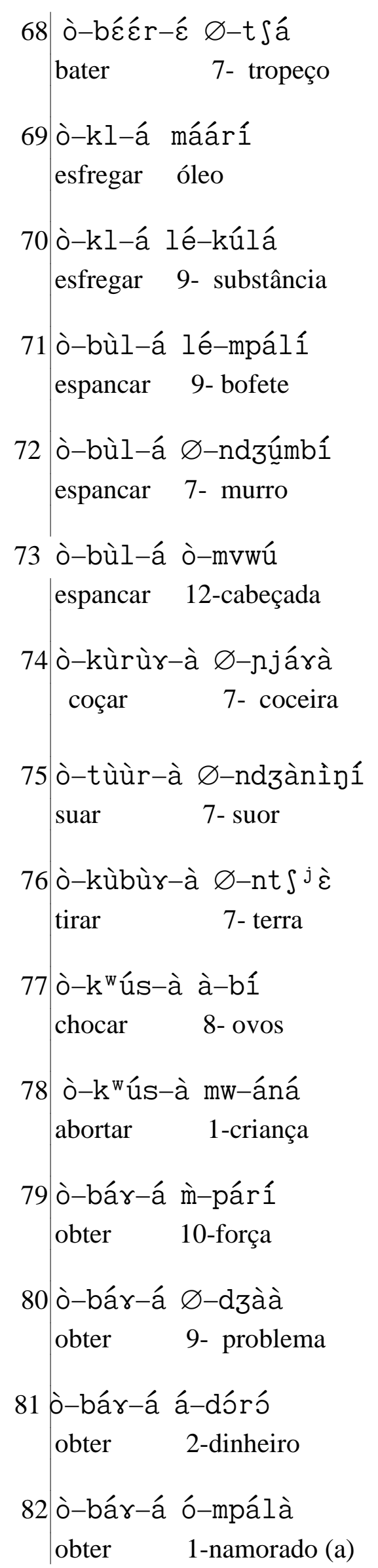

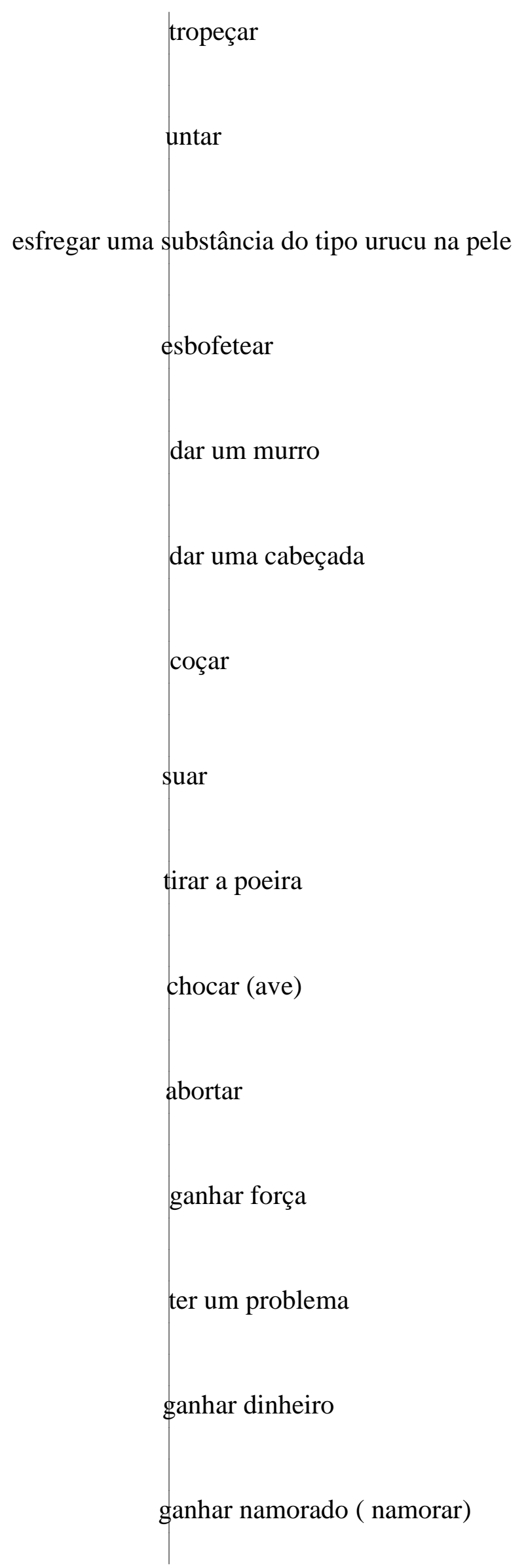




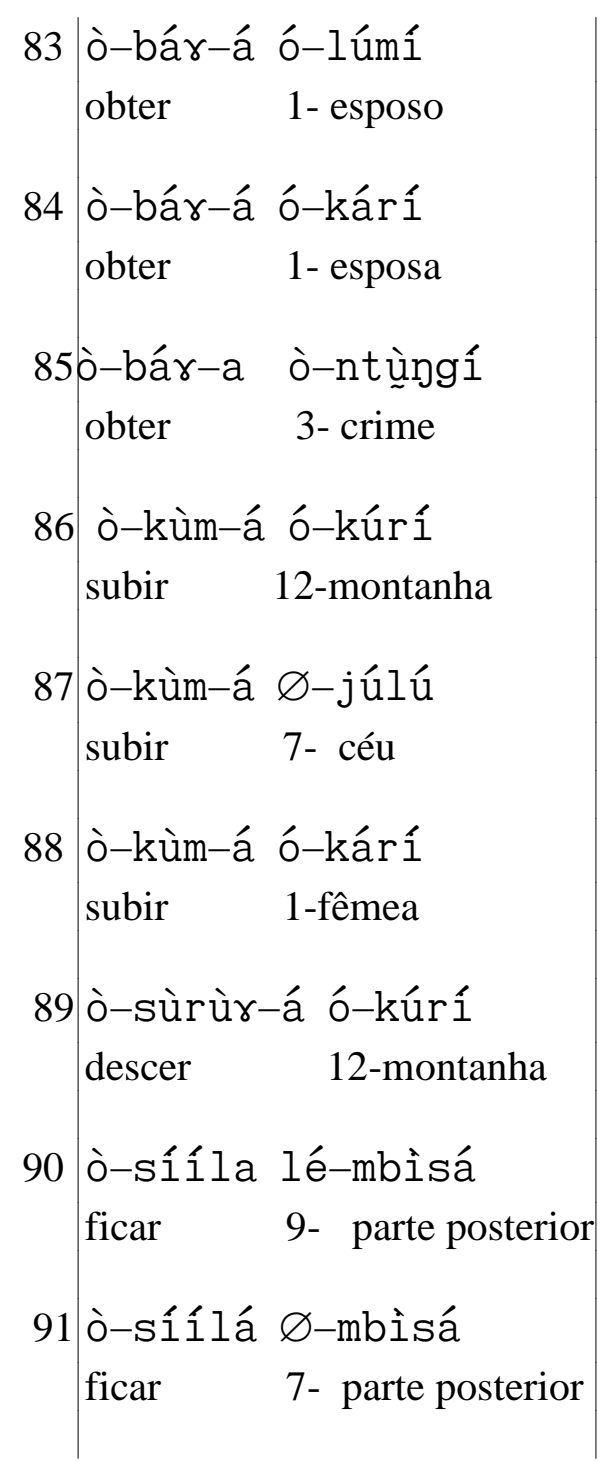

92 ò-d3wan-á $\varnothing$-ygrù brigar 7-briga

93 ò-dz ${ }^{j}-a ́$ Ø-tángà armar 7- armadilha

$$
94 \mid \begin{array}{ll}
\text { ò-tîn-á } & \varnothing \text {-ndîrì } \\
\text { marcar } & \text { 7-amizade } \\
96 \mid \begin{array}{ll}
\text { ò-tín-á } & \varnothing \text {-bárá } \\
\text { cortar } & \text { 7-faca } \\
\text { ò-tb-á } & \varnothing \text {-sòrí } \\
\text { furar } & \text { 7-agulha } \\
\text { ò-tb-á } & \varnothing \text {-bárá } \\
\text { furar } & 7 \text {-faca }
\end{array}
\end{array}
$$

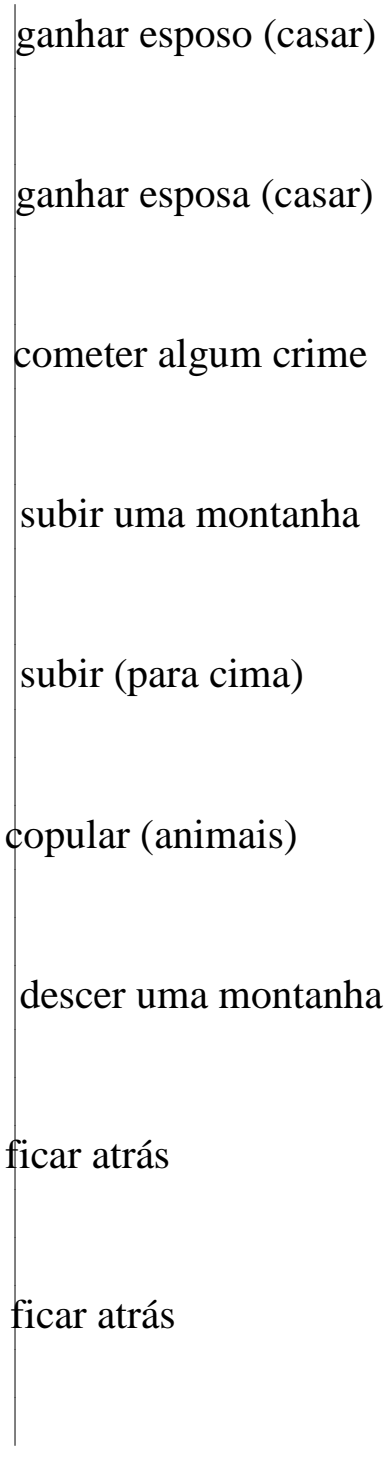

brigar

armar uma armadilha (para animais)

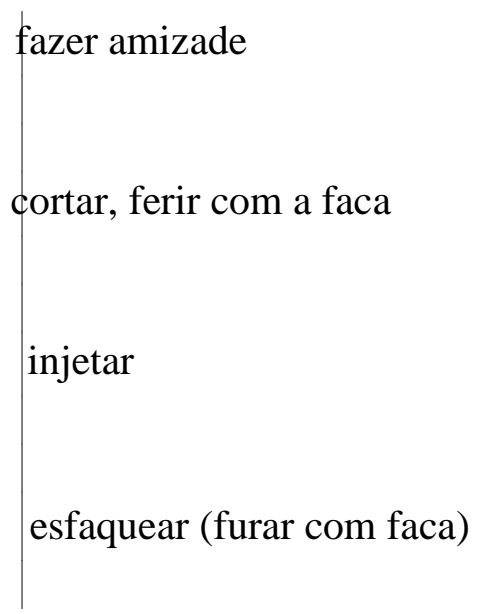




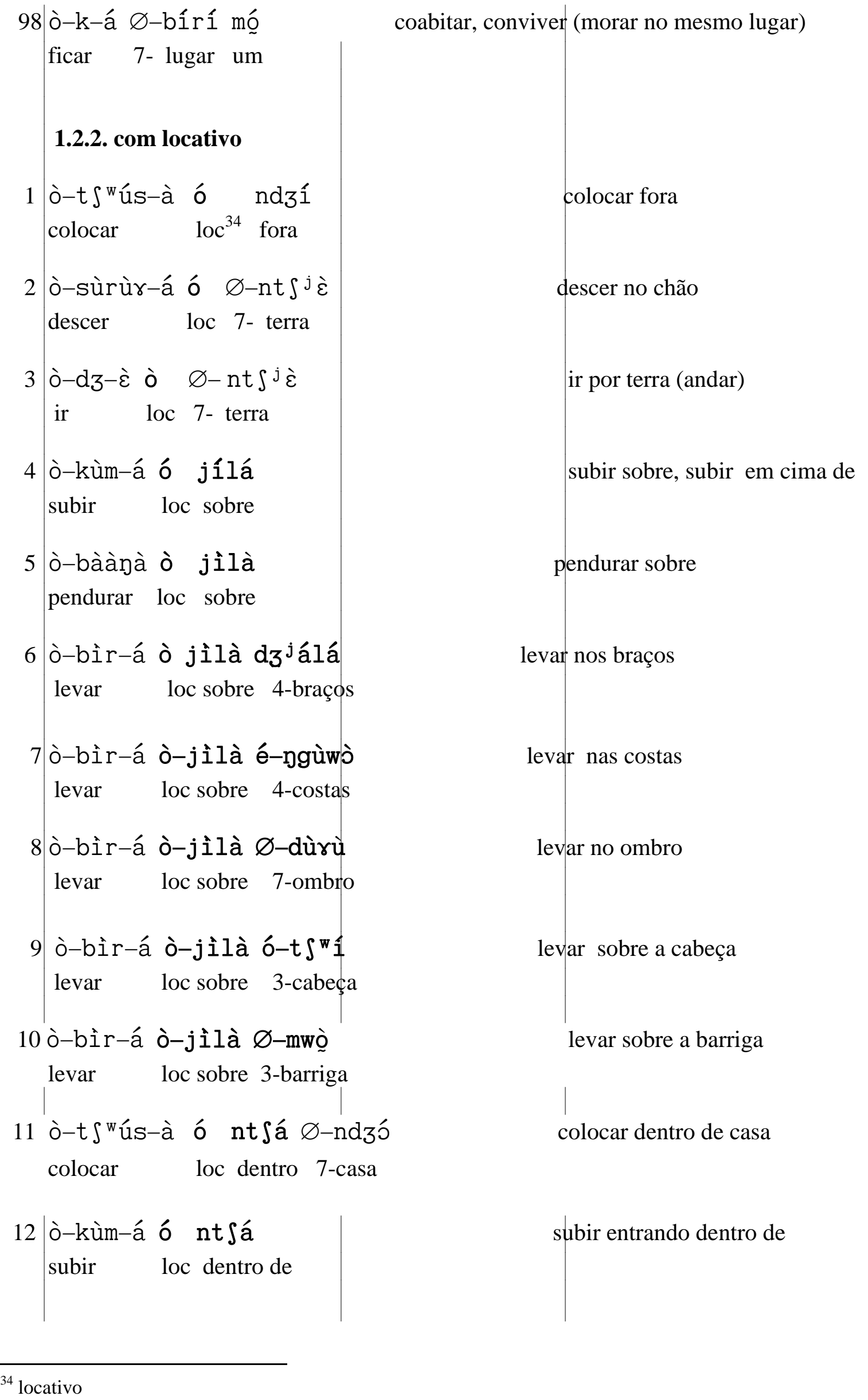


$13\left|\begin{array}{lrr}\text { ò-1-ó má } & \text { á-ndzá } \\ \text { pôr } & \text { loc } & \text { 8- água }\end{array}\right| \quad$ pôr na água (pôr de molho)

1.2.3.com advérbio, preposição e/ou ideofone que indicam a maneira, a quantidade, etc.

1 ò-jàlàr-à mà ó-t $\int^{w} \hat{1}$ responder $\operatorname{prep}^{35} 3$ - cabeça

2 ò-wóbó má à-wàwà falar prep 8 -ideofone ${ }^{36}$ (cochicho)

3 ò- $d z^{-\varepsilon}$ nà ò- $d z^{j} \varepsilon^{\varepsilon}$ ir prep passeio

4 ò-ts-á yà deitar prep

5 ò-sîíl-á nt Seeérí sobrar $\quad \operatorname{adv}^{37}$ pouco

6 ò-sííl-á kwùná sobrar adv. muito

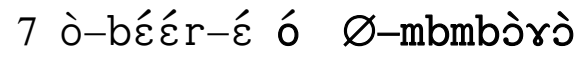
bater prep 7-ideofone (com força)

8 ò-nùsùr-à lé-mbìsá | acordar 9- atrás

$10\left|\begin{array}{lll}\text { ò-bìr-á ó } & \text { dz }{ }^{j} \text { álá } \\ \text { levar } & \text { prep } & \text { 4-braços } \\ \text { ò-bìr-á m’é-ngùwò } \\ \text { ò-bìr-á má } & \text { é-ngùwò } \\ \text { levar } & \text { prep } & \text { 4-costas } \\ \text { ò-bìr-á ó } & \varnothing \text {-dùrù } \\ \text { levar } & \text { prep } & 7 \text {-ombro }\end{array}\right|$
responder com a cabeça

cochichar, falar baixo

passear

deitar com

sobrar pouco

sobrar muito bater com força, de maneira aplicada acordar por último, acordar atrasado

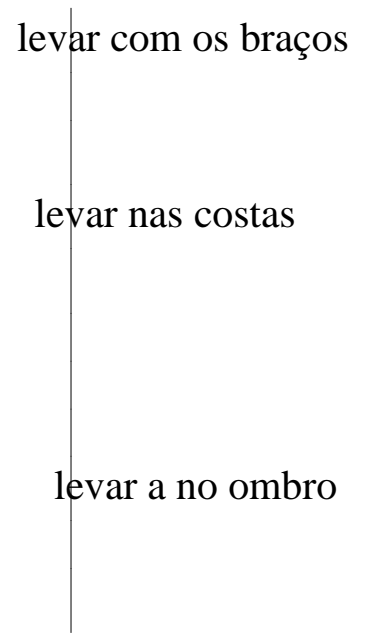

\footnotetext{
${ }^{35}$ Preposição

${ }^{36}$ Trata-se da associação de um som e de uma idéia. É uma palavra que é muitas vezes de origem onomatopaica que descreve um predicado, qualificador, ou advérbio de maneira, cor, cheiro, ação ou intensidade. ${ }^{37}$ Advérbio
} 
12

$\left|\begin{array}{lll}\text { ò-bìr-á m’ó-t } \text { w }^{\mathrm{i}} \\ \text { ò-bìr-á } & \text { mó } & \text { ó-t } \int^{w} \hat{1} \\ \text { levar } & \text { prep } & 3-\text {-cabeça }\end{array}\right|$

13 ò-bìr-á ó $\varnothing$-mwò

levar prep 3-barriga levar na cabeça

levar na barriga

1.3. Verbos leves: são verbos cuja significação é dada pelo complemento.
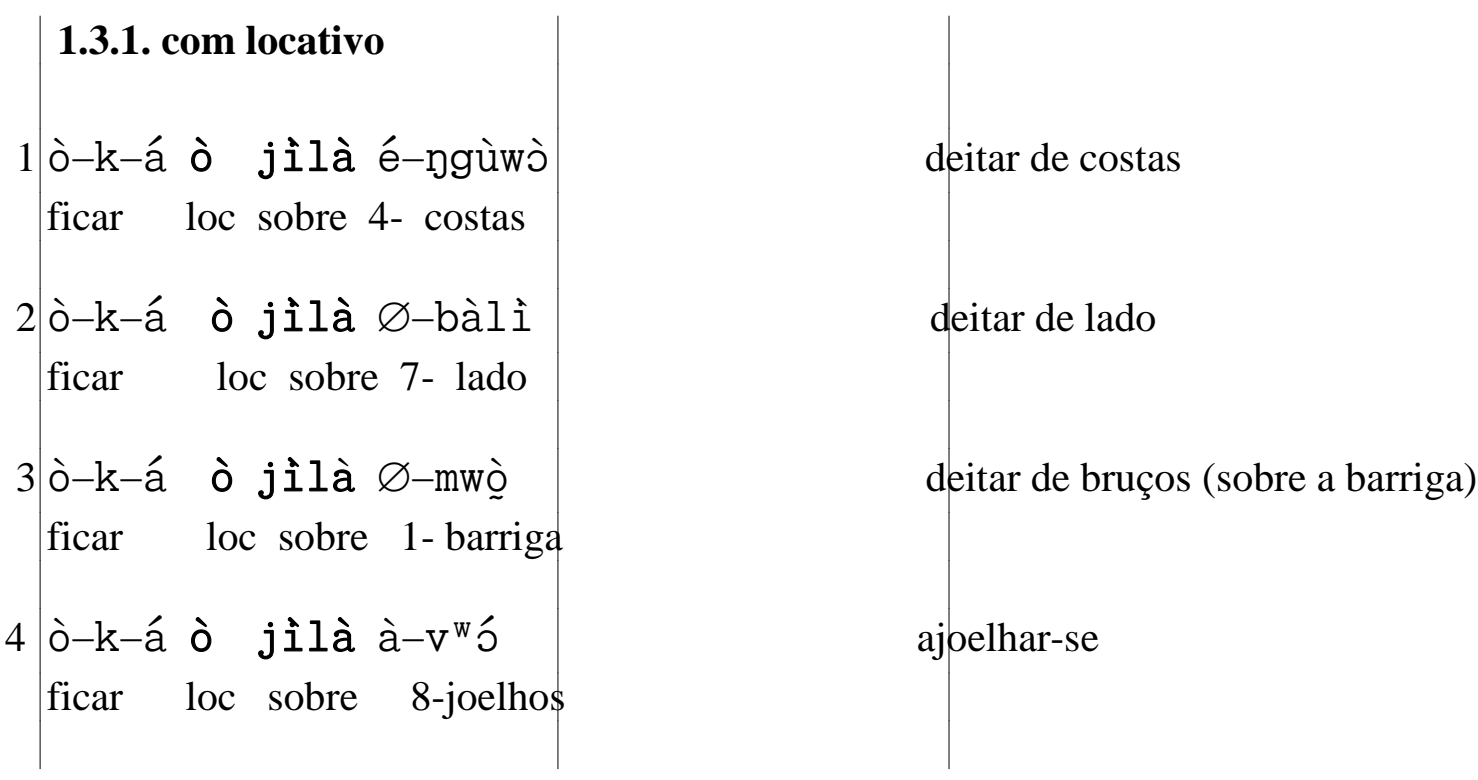

\subsection{2. com preposição, advérbio, qualificador e/ou ideofone que indicam a maneira, o lugar, o instrumento, etc}
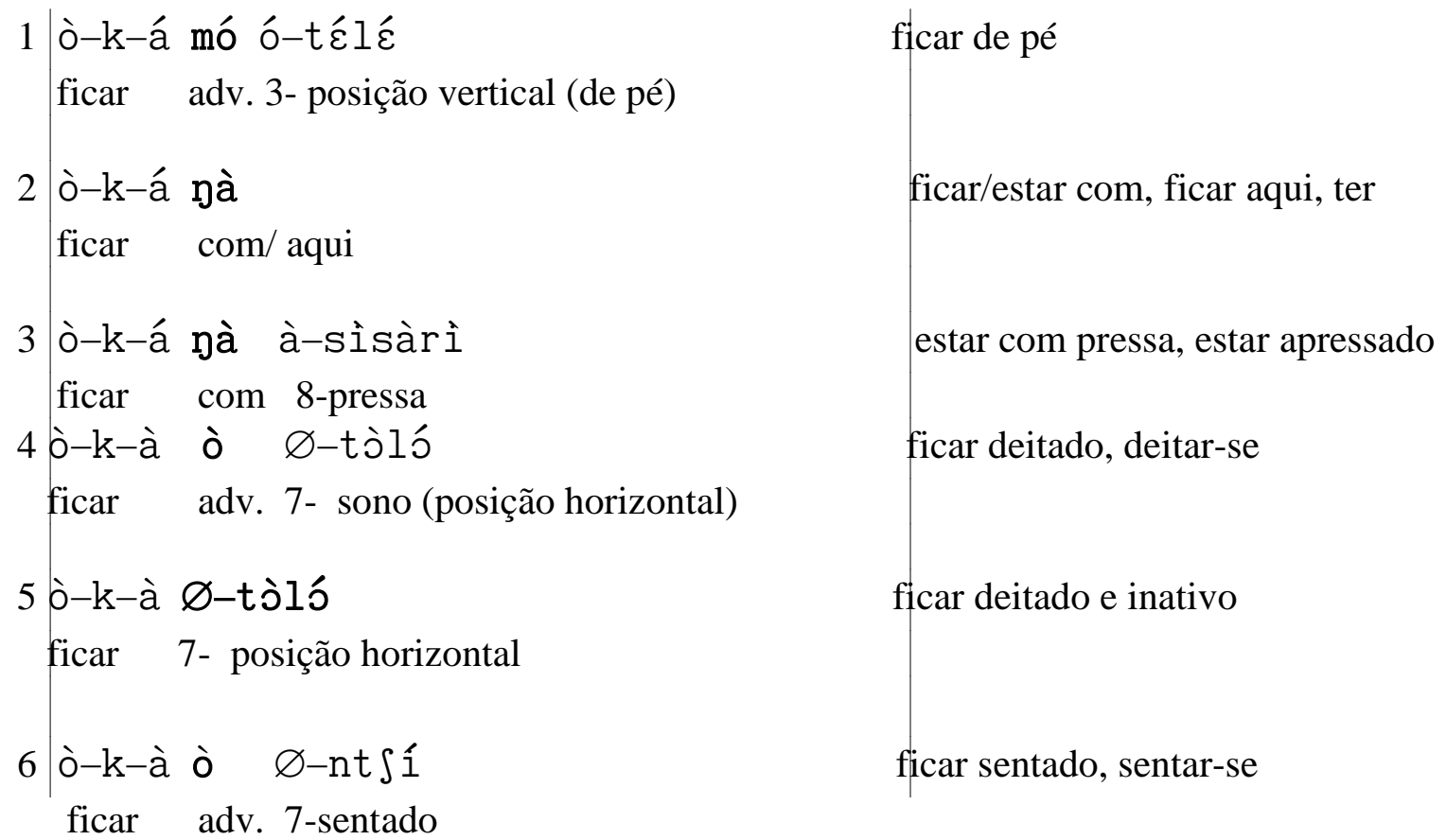


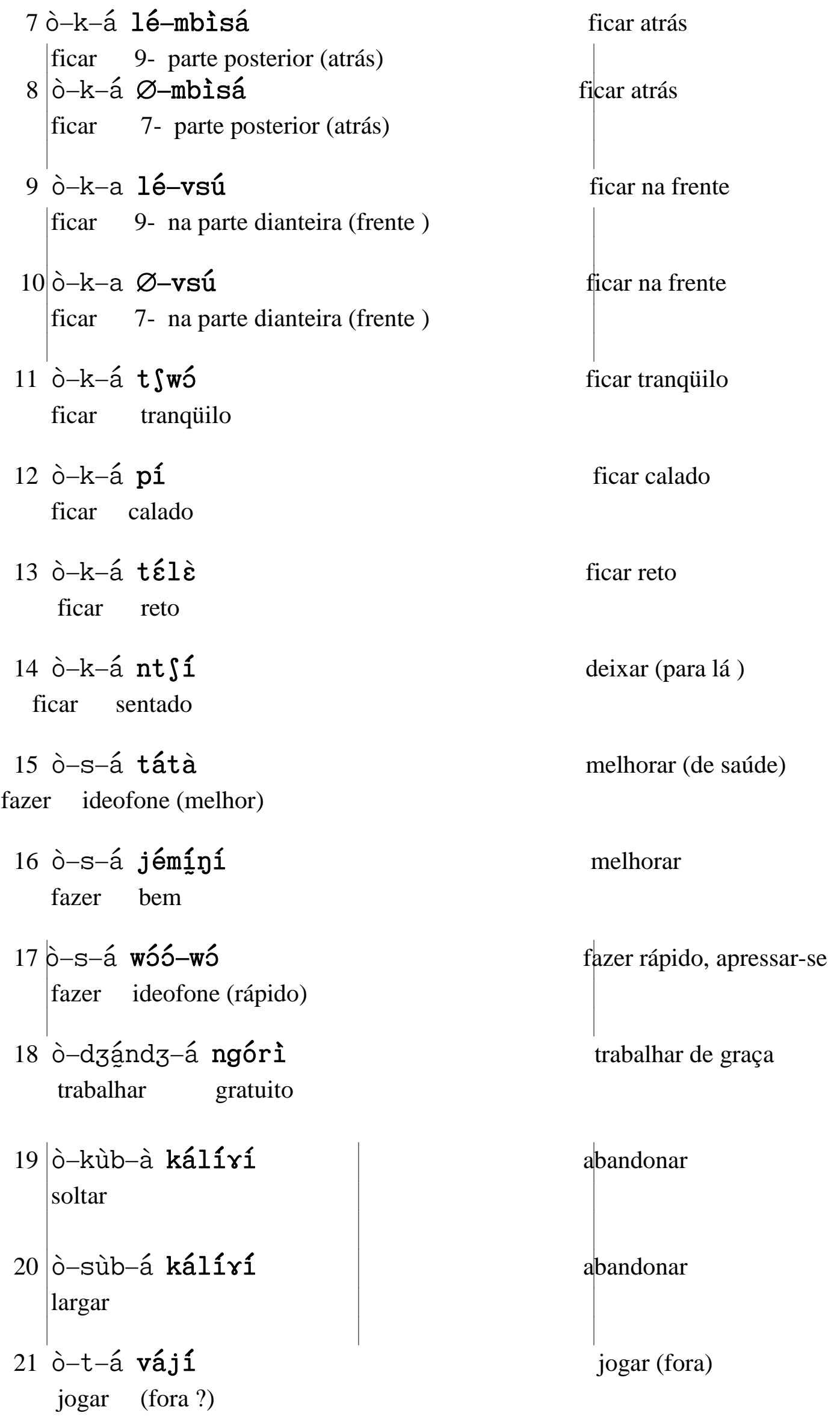




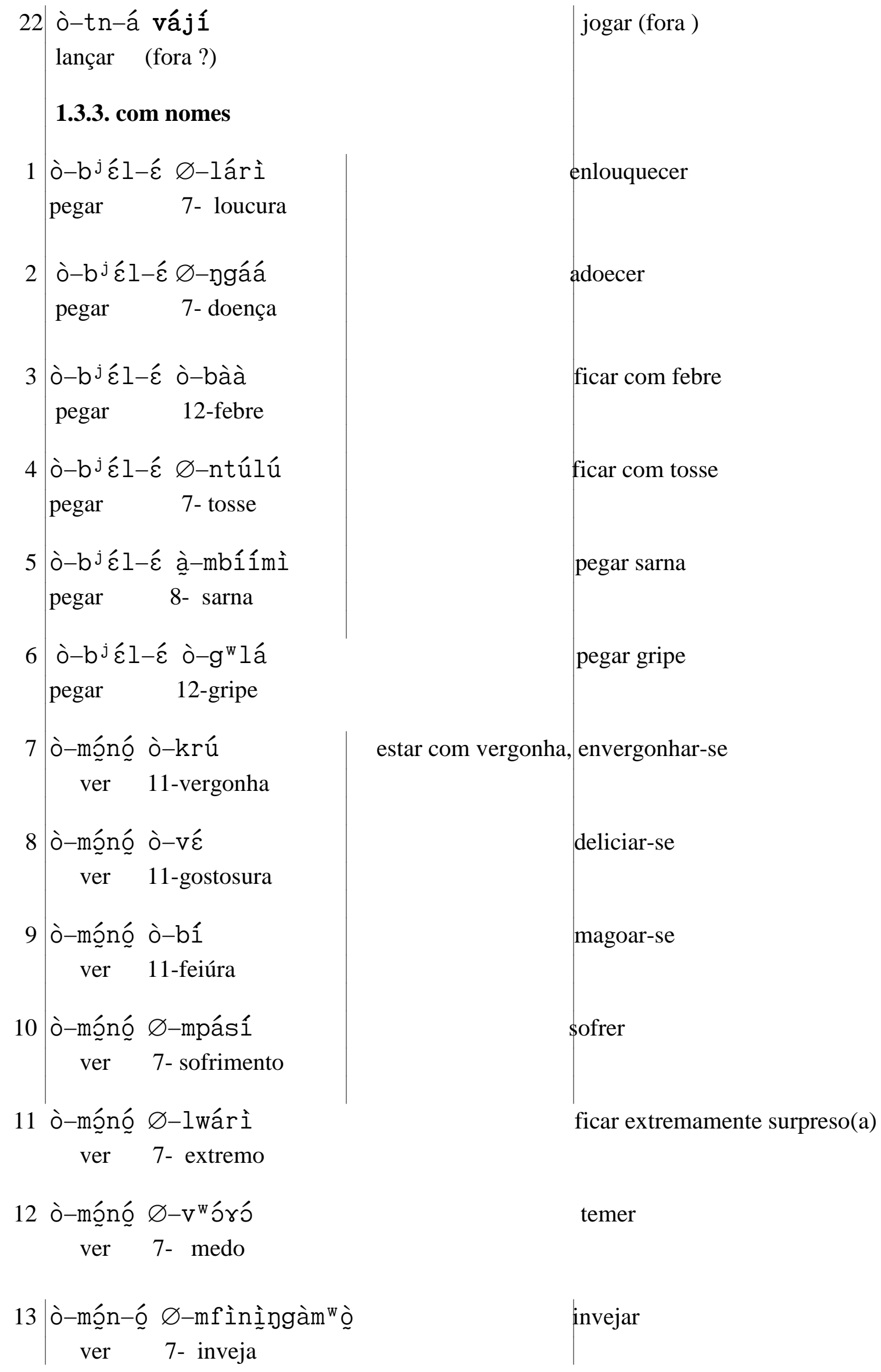




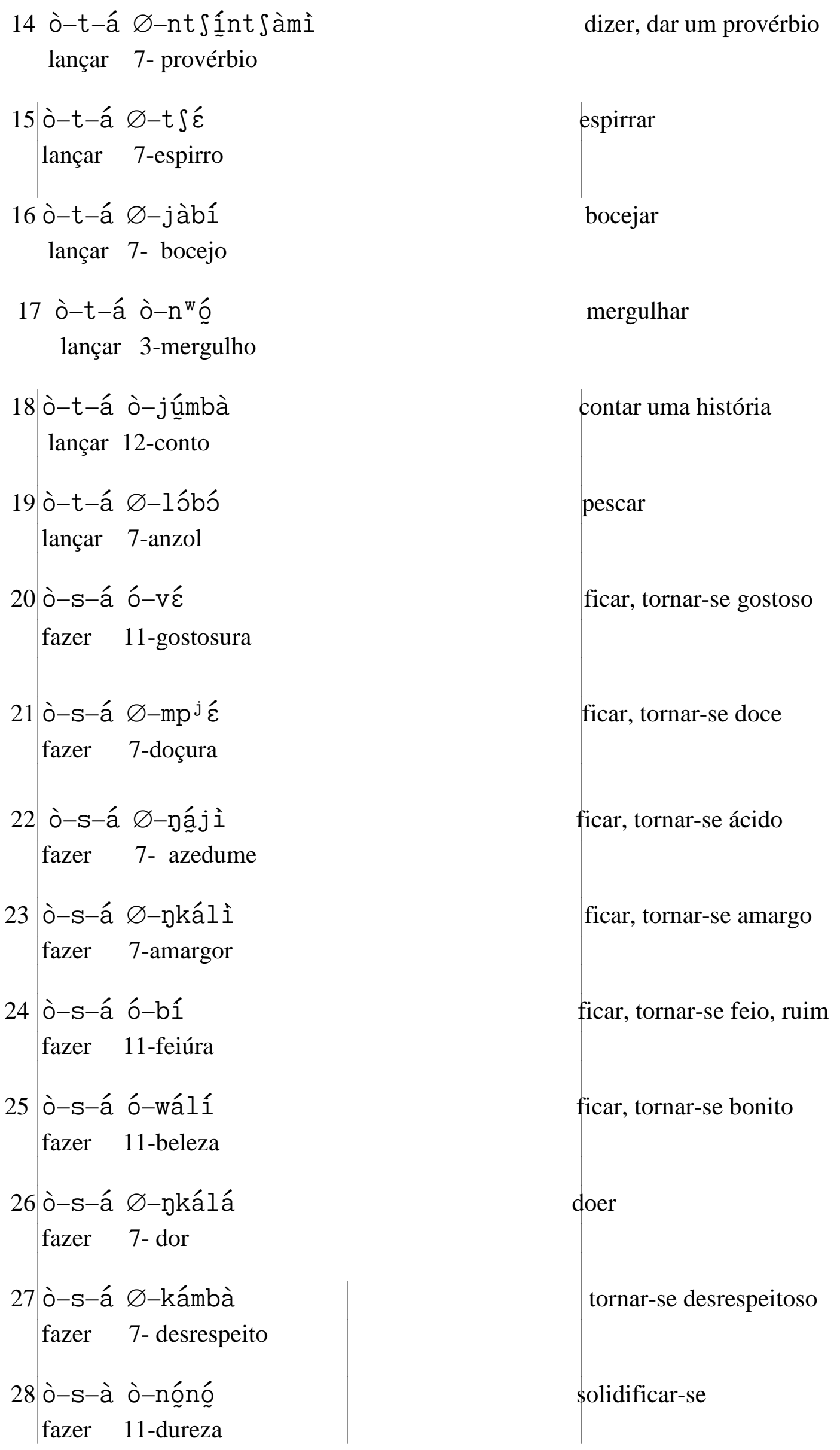




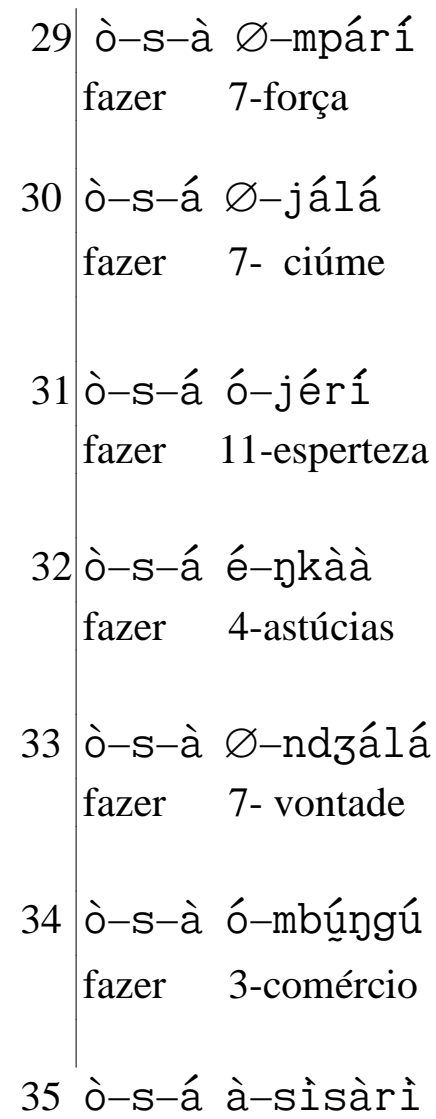

35 ò-s-á à-sìsàrì fazer 8-pressa

36 ò-dzórò $\varnothing$-mparí gabar-se 7-força

37 ò-dzórò á-dóró gabar-se 2-dinheiro

38 ò-t j jéśc ò-kî́ngá tirar 11-virgindade

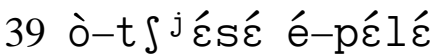
tirar 4-pratos

40 ò-t ${ }^{j} \varepsilon^{\varepsilon}$ ś á-bíî́ tirar 8-bichos do pé

41 ò-t $\int^{j} \varepsilon s-\varepsilon$ à-mfá tirar 8-roupa

42 ò-t $\int^{j} \varepsilon s-\varepsilon$ à-kóróró tirar 8-sapatos

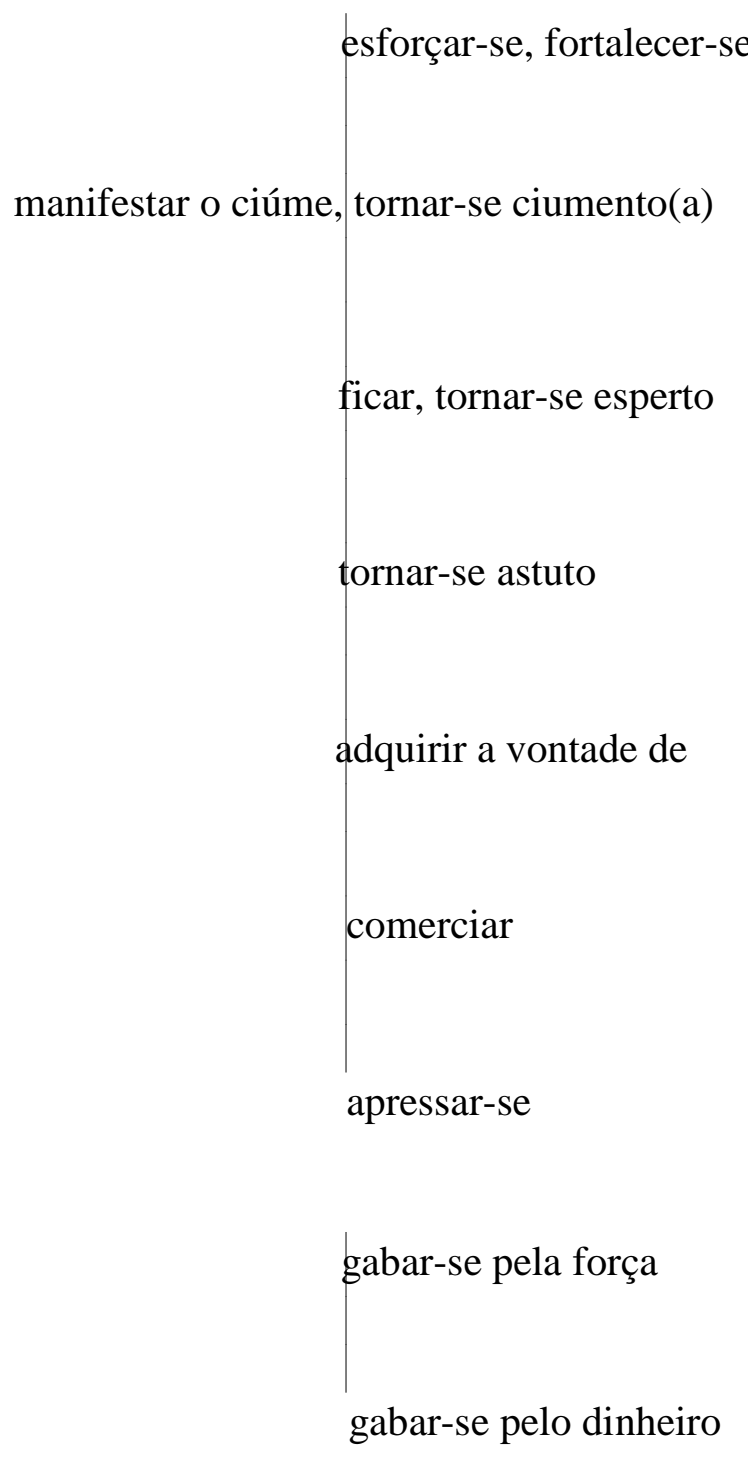

desflorar

desfazer a mesa depois de comer

tirar os bichos do pé

despir(se)

tirar os sapatos, ficar descalço 


\subsection{Verbos Transitivos com dois objetos}

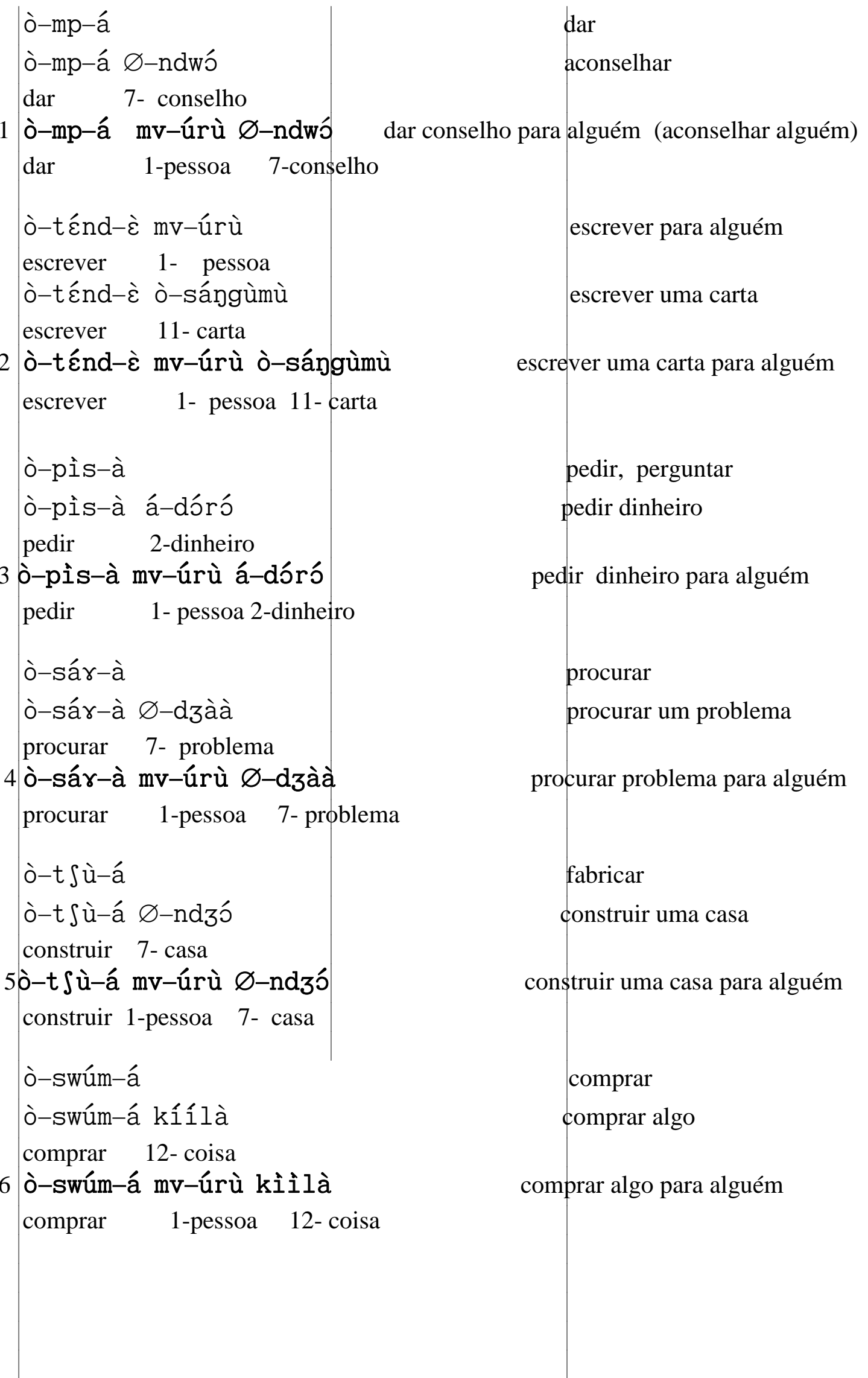




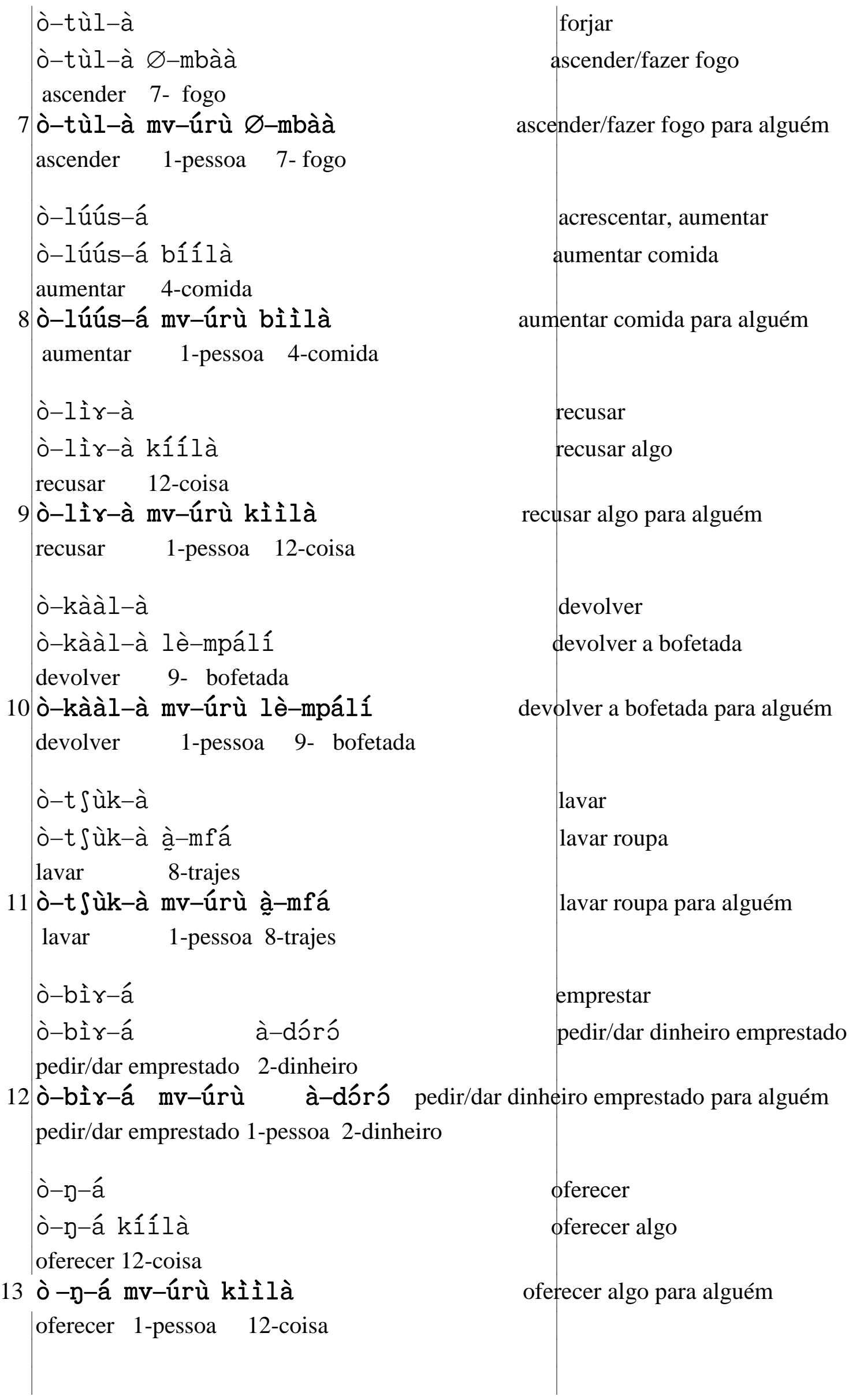




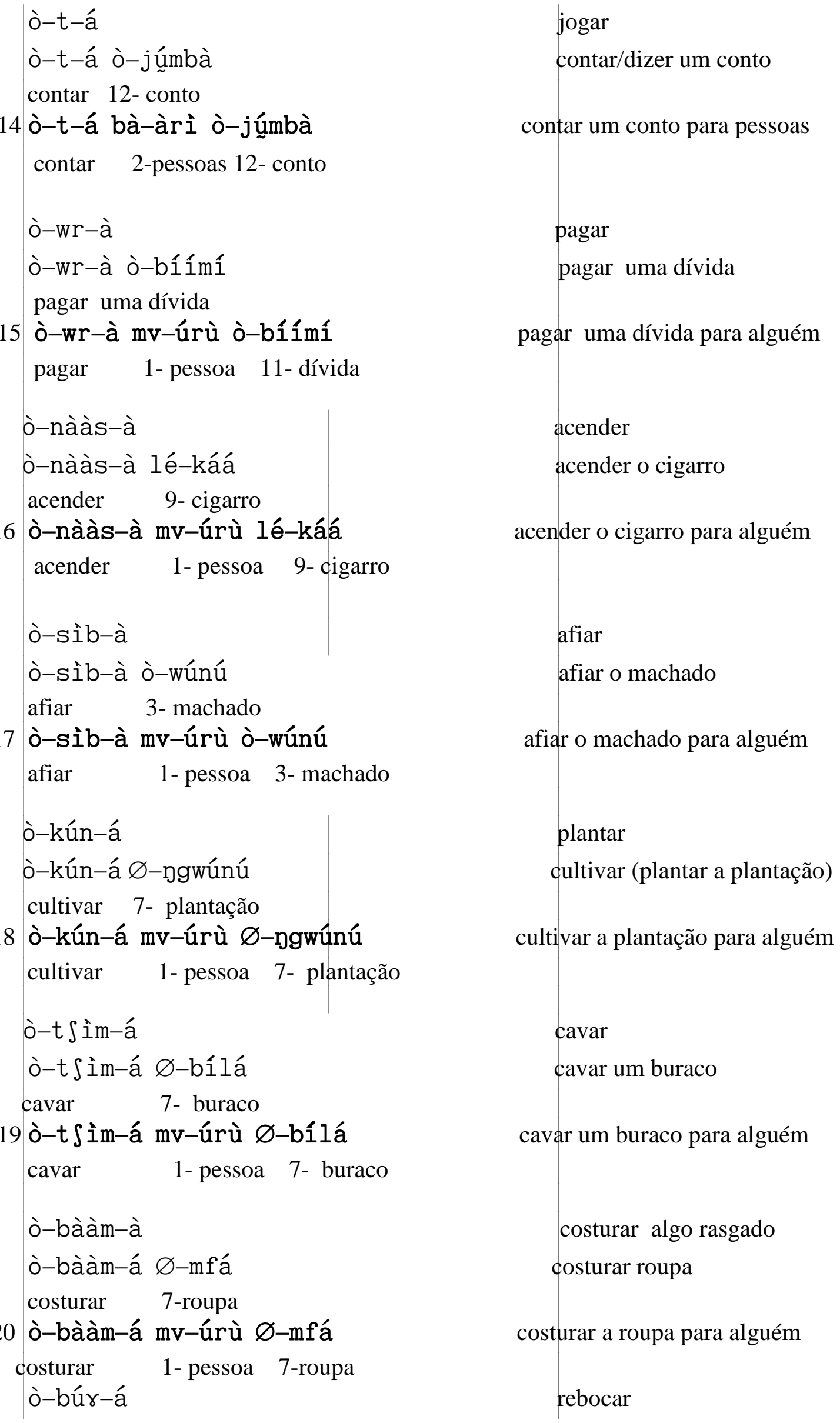




$$
\begin{aligned}
& \text { ò-búr-á } \varnothing \text {-ndzó } \\
& \text { rebocar 7-casa } \\
& 21 \text { ò-búr-á mv-úrù Ø-ndzó } \\
& \text { rebocar 1-pessoa 7-casa } \\
& \text { ò-k }{ }^{j} \varepsilon^{\prime} l-\varepsilon \\
& \text { ò-k } \mathrm{k}^{\mathrm{j}} \varepsilon 1-\varepsilon \text { kíî́là } \\
& \text { guardar 12-algo }
\end{aligned}
$$

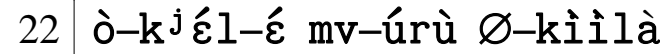

guardar 1-pessoa 12-algo

ò-bî́nd-à

ò-bî́n'nd-à - -ndzó

trancar 7-casa

23 ò-bî́ñ-à mv-úrù $\varnothing$-ndzó

trancar 1-pessoa 7- casa

ò-náán-à

ò-náán-à $\varnothing$-ndzó

abrir 7- casa

24 ò-náán-à mv-úrù $\varnothing-n d 3 o ́$

abrir 1-pessoa 7- casa

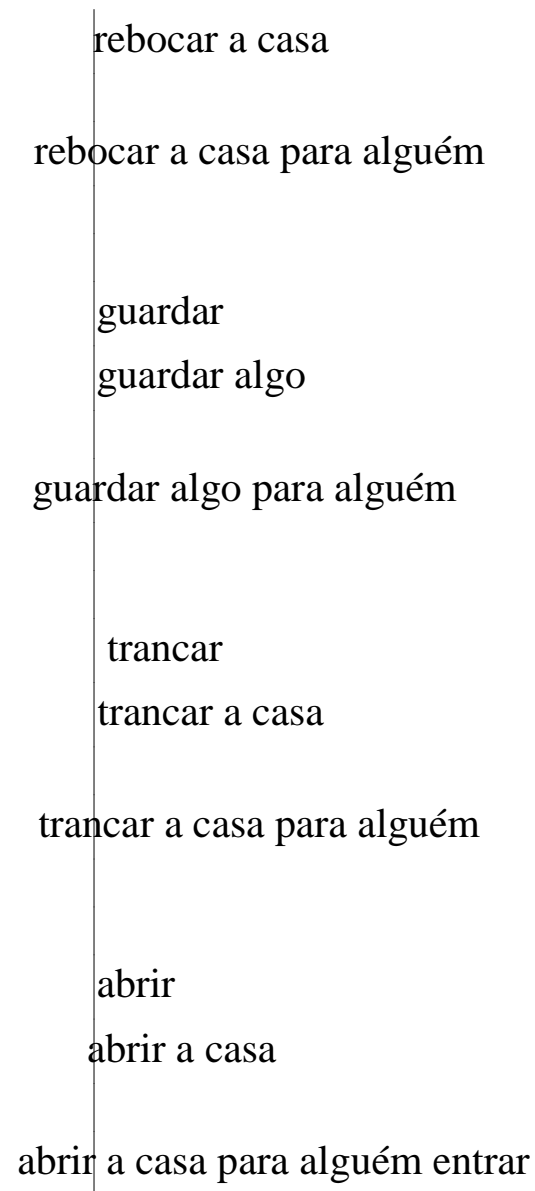




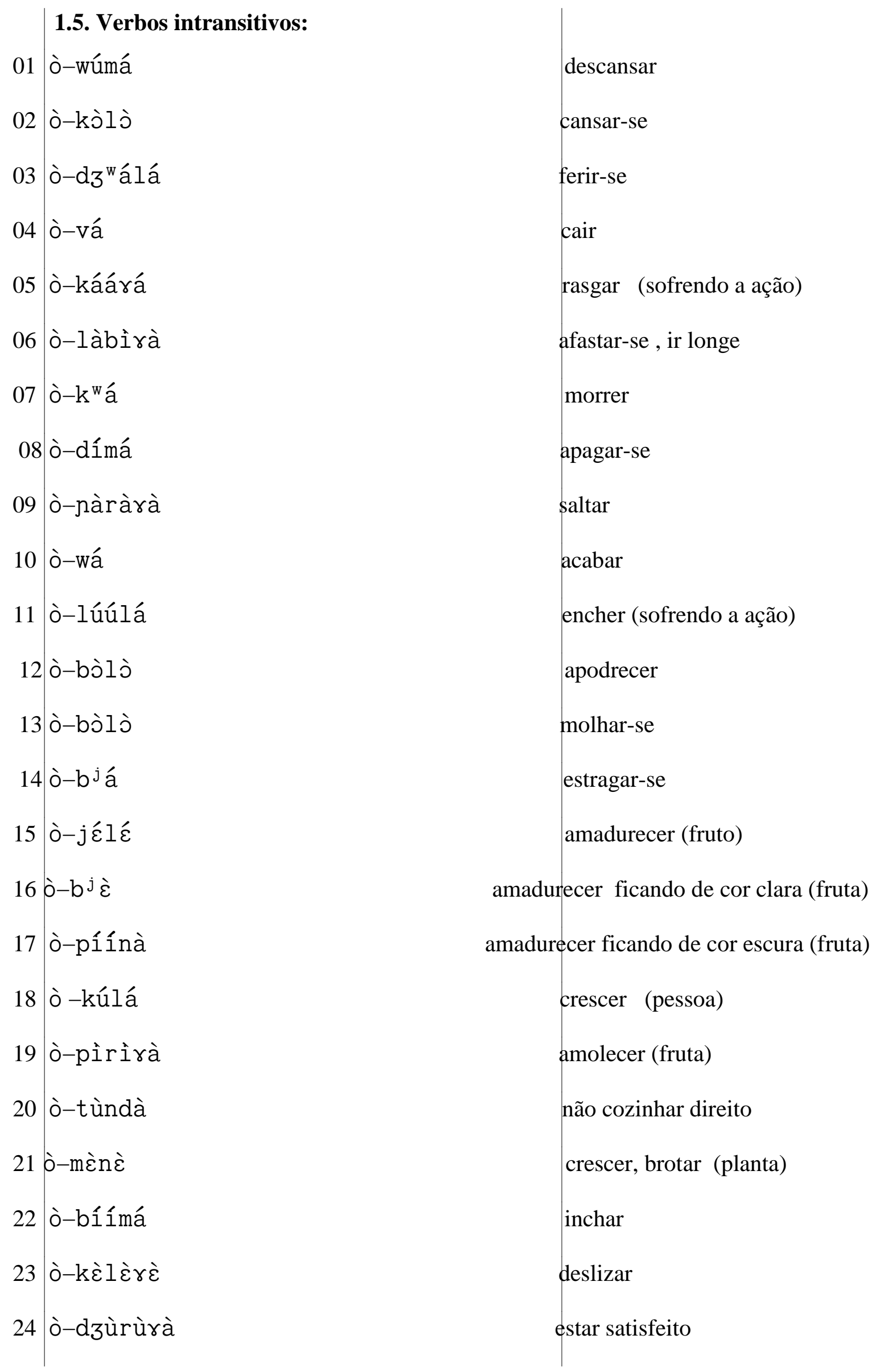




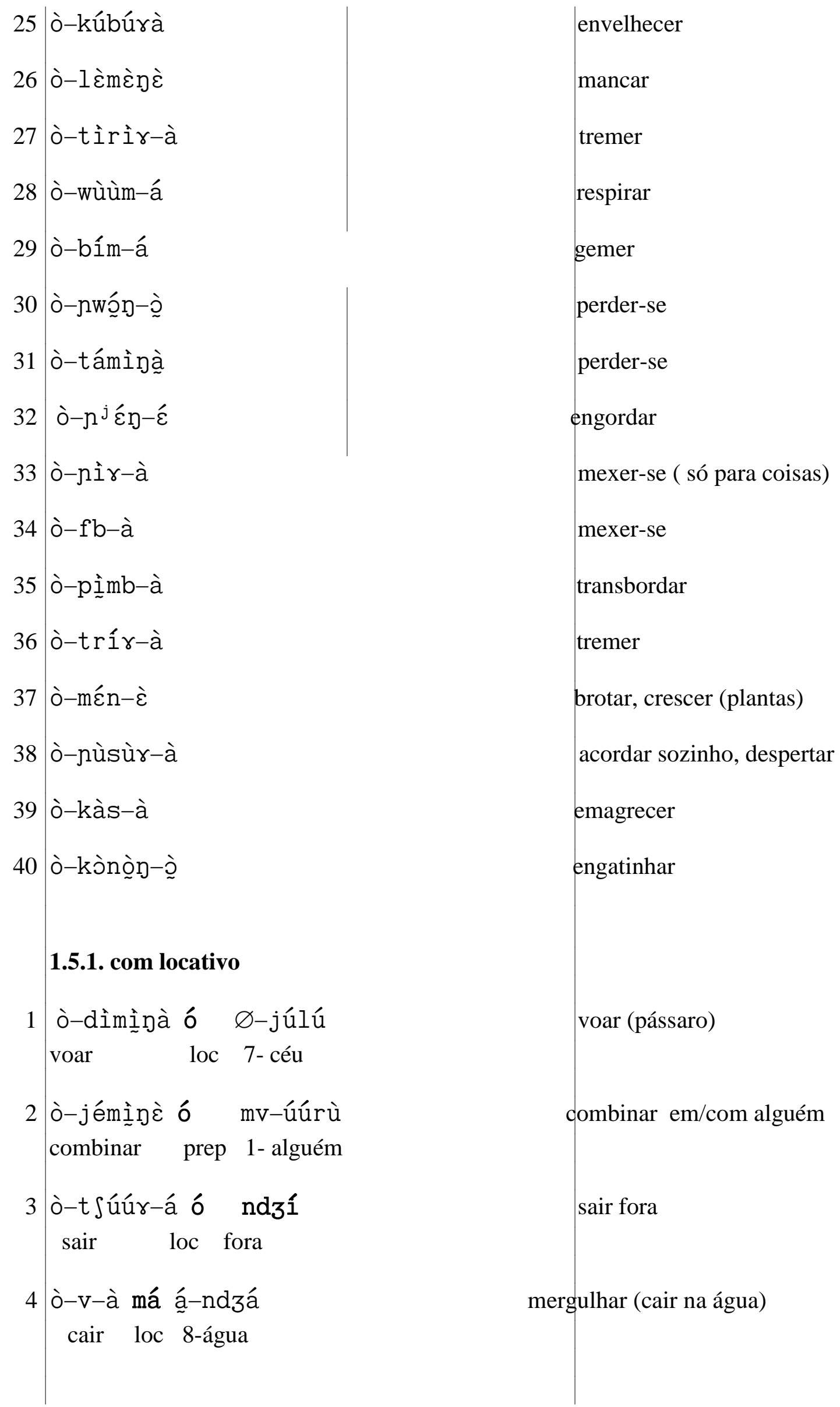



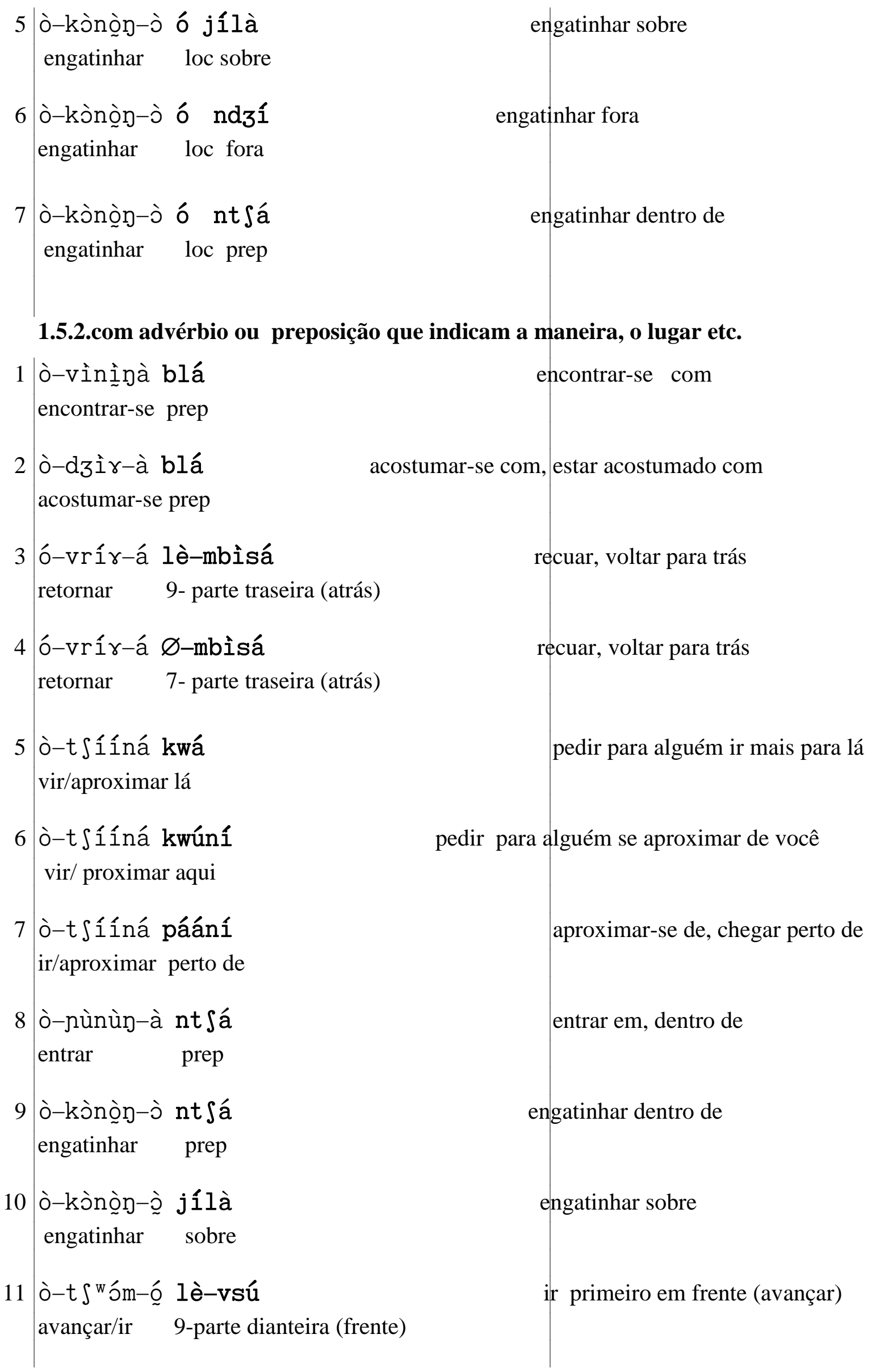
12 ò-t $\int^{w}$ óm-ó $\varnothing$-vsú

avançar/ir 7-parte dianteira (frente)

mas temos:

13

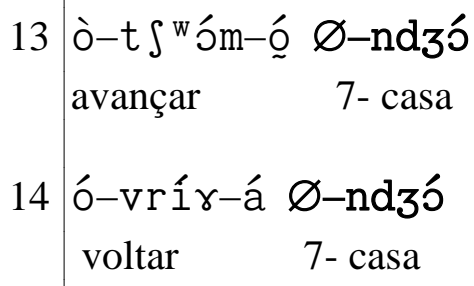

it primeiro em frente (avançar)

\subsubsection{Verbos intransitivos que se referem a fenômenos naturais:}

02

ò-nór-ó [Ø-mvlá à nóró ]

chover

1- chuva IS chover

03 ò-bál-á [Ø-mwî̃ á bálá ] fazer sol 1-sol IS fazer sol

03

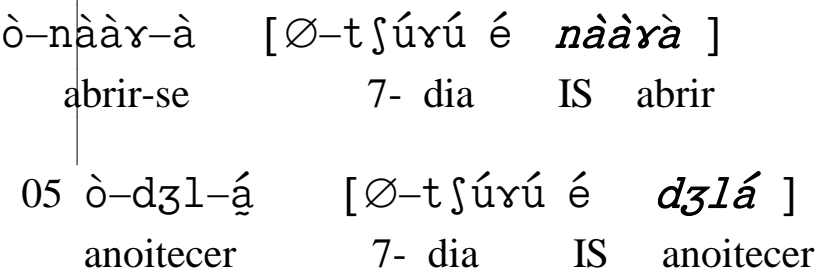

avançar para casa

voltar para casa

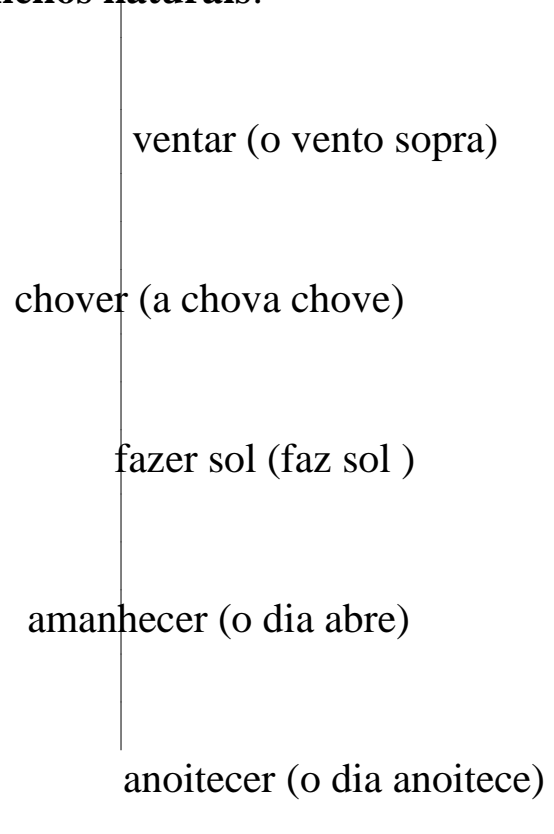

\subsection{Expressões idiomáticas}

01. Ø-ndzàlà ò-s-á

a fome se manifesta

7- fome

fazer

02. $m$

$\begin{array}{ll}\varnothing \text {-ndzàlà è sá } \\ \text { 7-fome } & \text { IS fazer }\end{array}$

03. $\varnothing-m p^{j} \varepsilon \quad$ à-ndzá ò-s-á

a sede se manifesta

7- gosto

8- água fazer

04. $m \varepsilon \grave{\varepsilon} \varnothing-m p^{j} \varepsilon$ à-ndza è sá

estou com sede

estou com fome

1s 8-gosto 8-água IS fazer

${ }^{38} 1^{\mathrm{a}}, 2^{\mathrm{a}}, 3^{\mathrm{a}}$ pessoa do singular/ $\mathrm{P}$. ou $\mathrm{pl}=$ plural. 
05. Ø-tòlo ò-s-á

o sono se manifesta

7- sono fazer

06. mè $\varnothing$-tòlo lé sá

estou com sono

1s 7-sono IS fazer

\subsection{Verbos que expressam ações diferentes:}

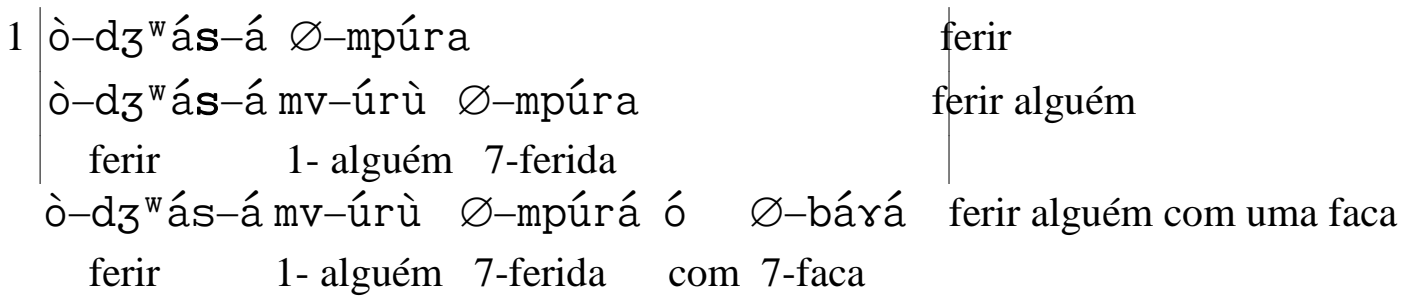
2 ò-d3ª́l-á $\varnothing$-mpúrá
mv-úrù ó mí dz'wál-á $\varnothing$-mpúrá
1-pessoa IS P1 ferir-se 7-ferida

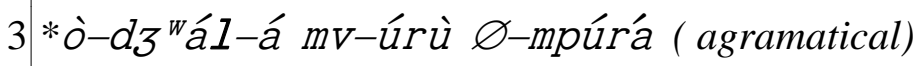
ò-tb-á

ferir-se

a pessoa feriu-se

urar

4 ò-tb-á

$\varnothing$-sòrí

injetar

furar 7- agulha

ò-tb-á mv-úrù $\varnothing$-sòrí

injetar alguém

furar 1-pessoa 7-agulha

ò-tb-á

5 ò-tb-á Ø-bárá

furar 7- faca

ò-tb-á mv-úrù $\varnothing$-bárá

furar 1- pessoa 7 -faca

6 ò-tbìr-á

urar-se (furar sozinho)

$7 \mid \begin{aligned} & \text { ò-dz-á } \\ & \text { ò-dz-á è-sáání } \\ & \text { comer 4- mal-entendido }\end{aligned}$

comer

resolver o mal-entendido

ò-d3-á mv-úrù è-sáápí fazer alguém confessar suas mágoas e tirá-las

comer 1-alguém 4-mal-entendido 
8 ò-kùr-a

ò-kùr-a $\varnothing-n t \int w a ́$

ò-kùr-á mv-úrù $\varnothing-n t \int w a ́$ amarrar 1-alguém 7- proteção

ò-búl-á

9 ò-búl-á lè-mpálí

espancar 9-bofetada

ò-búl-á mv-úrù lè-mpálí

espancar 1-pessoa 9-bofetada

10 mw-áná à búlá ò-lạ́ngù

1-criança IS quebrar 1-garrafa

11 ò-búlùr-à

ò-táálá ó mí búlùrà

12-espelho IS P1 quebrar-se

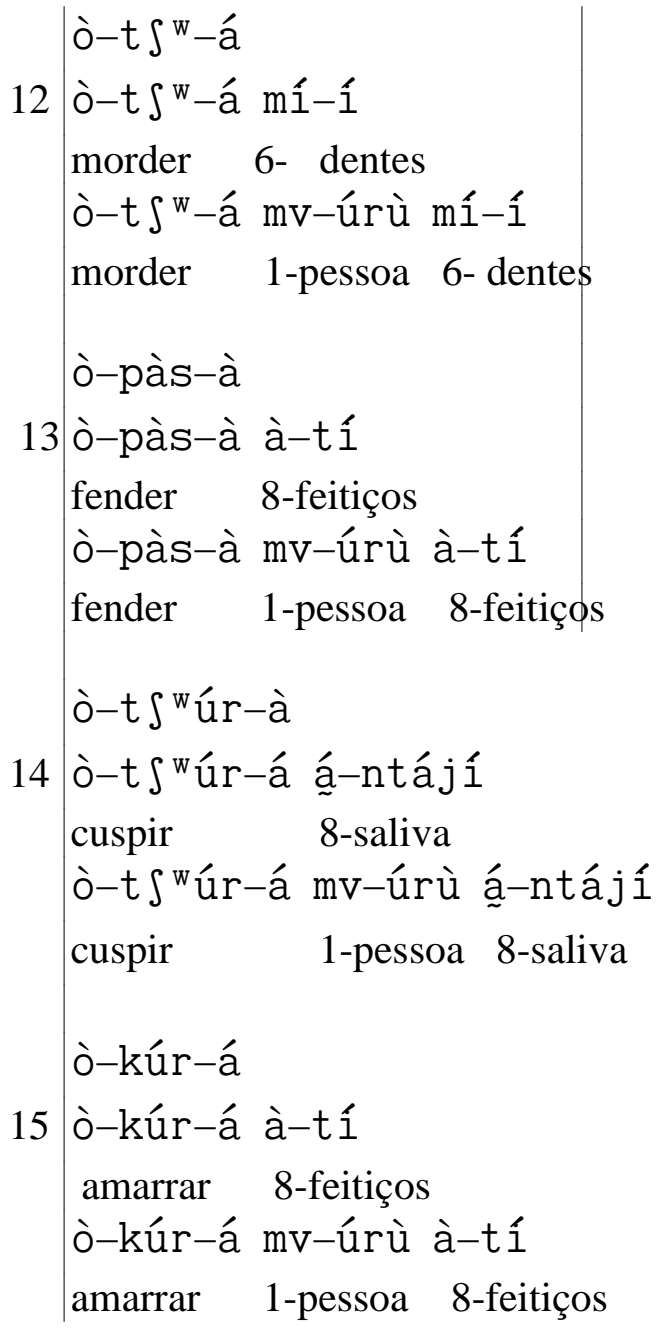

amarrar

proteger contra a bruxaria

proteger alguém contra a bruxaria

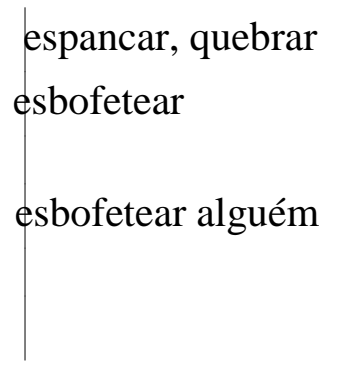

a criança quebra a garrafa

quebrar-se

o espelho quebrou-se

morder
morder com os dentes
morder alguém
fender
tornar-se bruxo ou mágico
tornar alguém bruxo ou mágico
pôr para fora da boca
cuspir
cuspir em alguém
amarrar
fazer um feitiço 


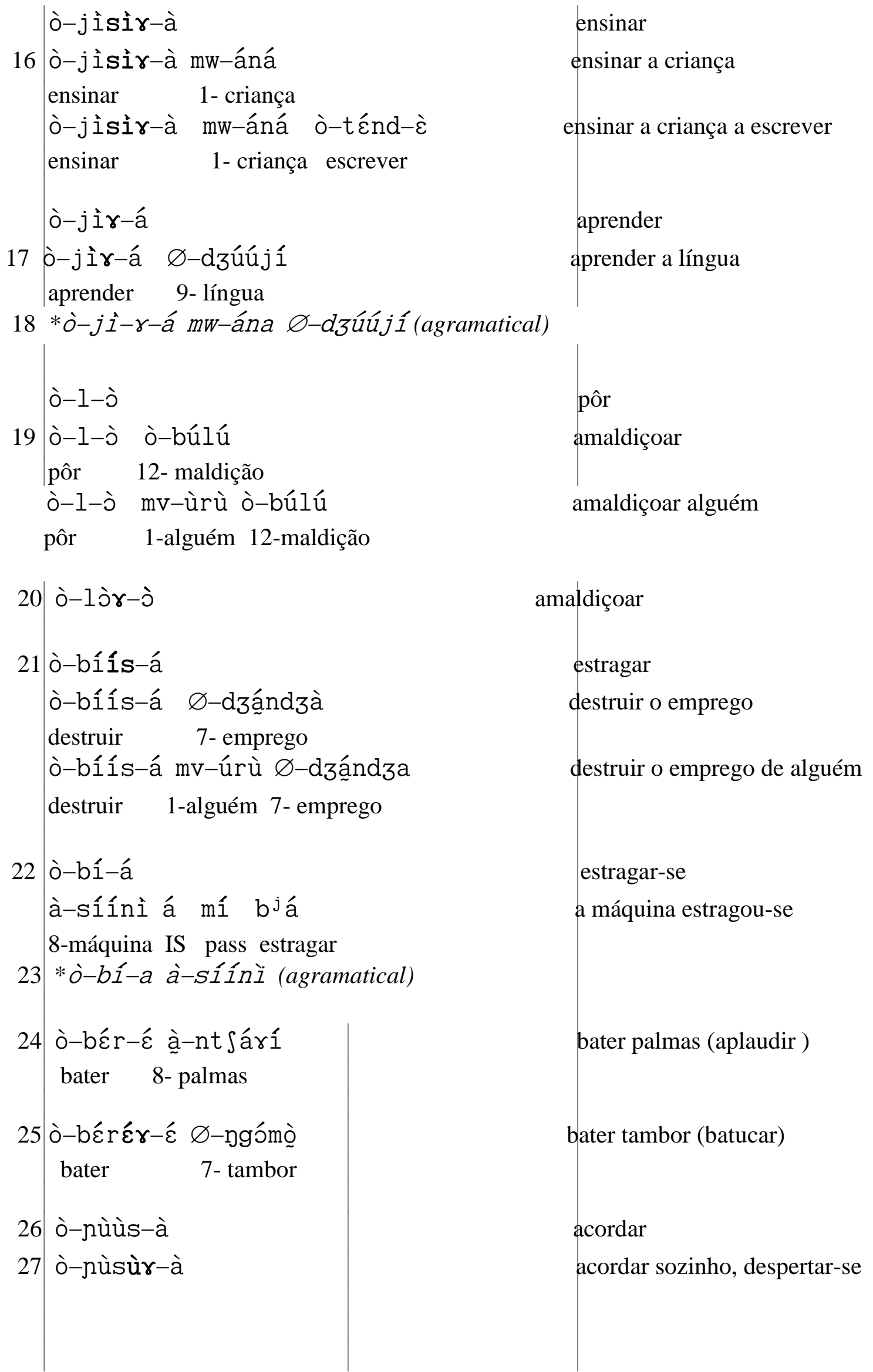




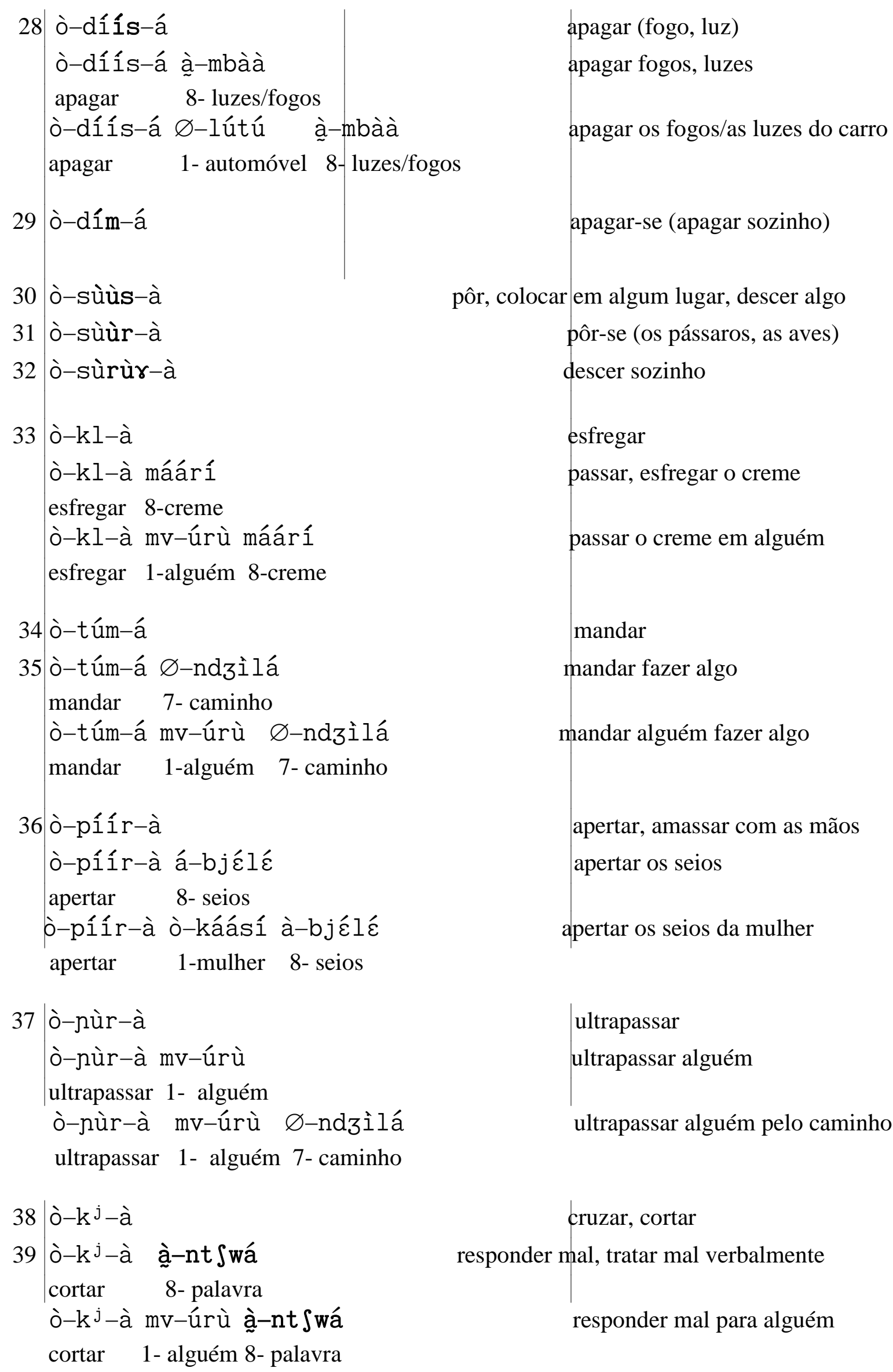




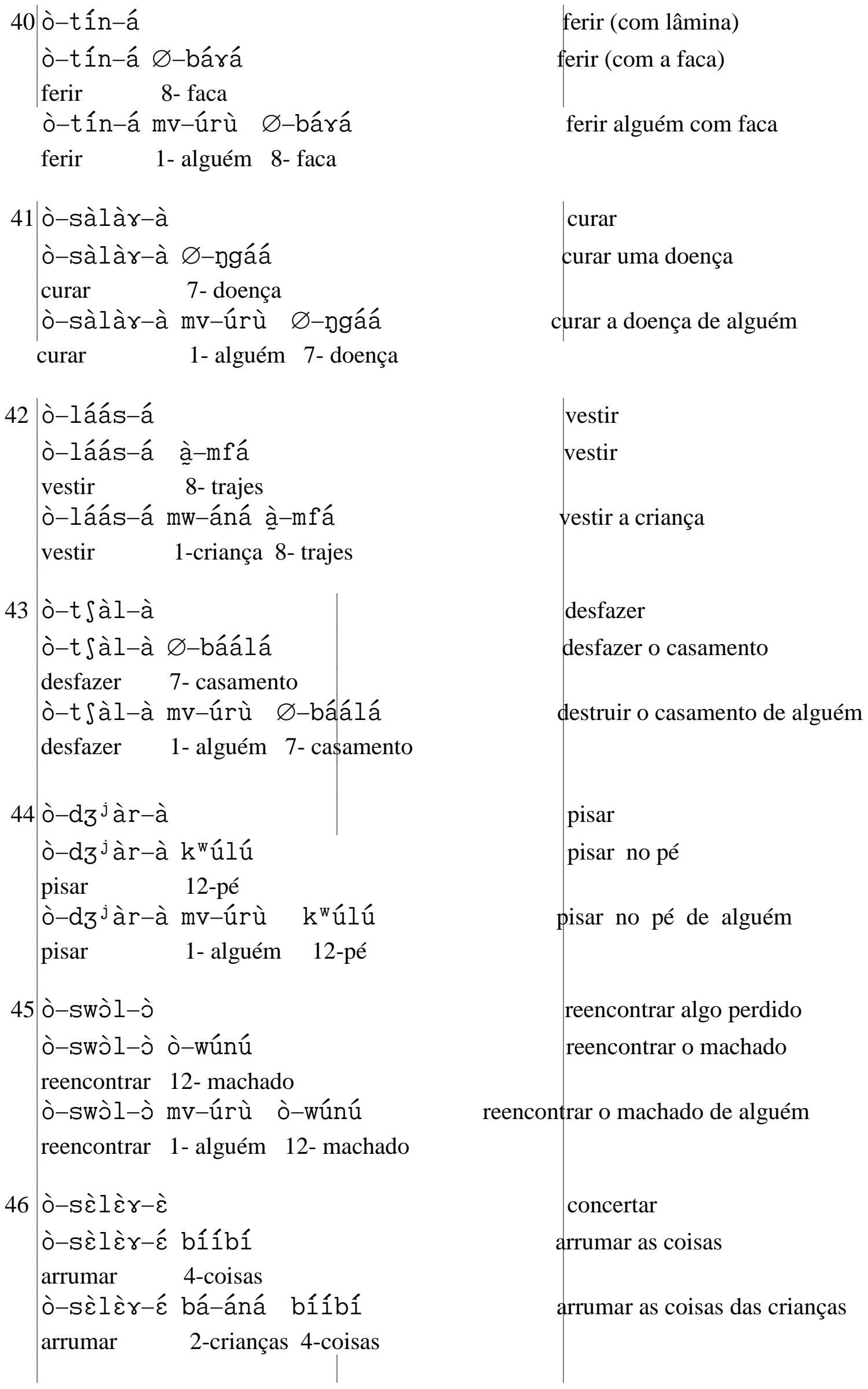




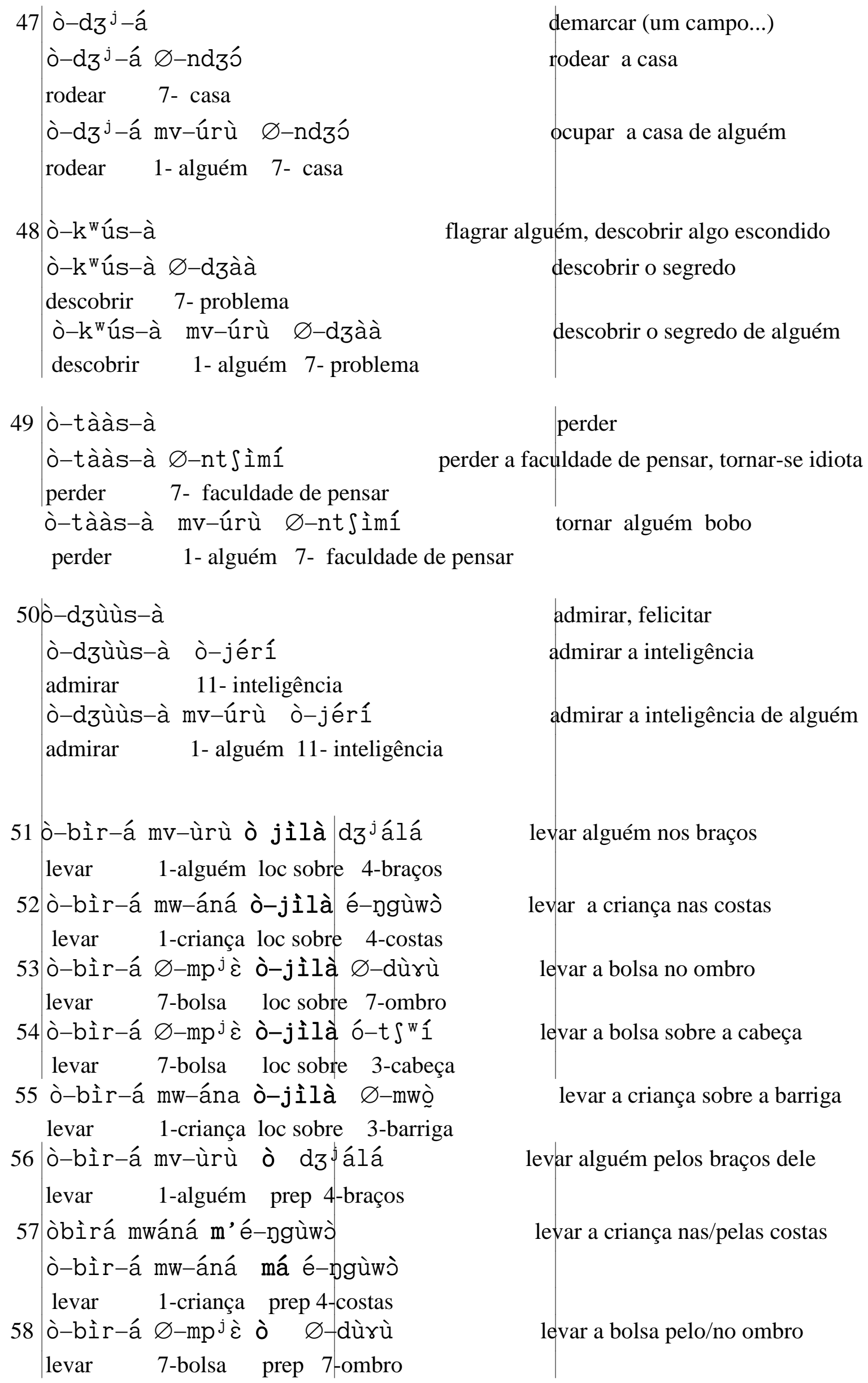




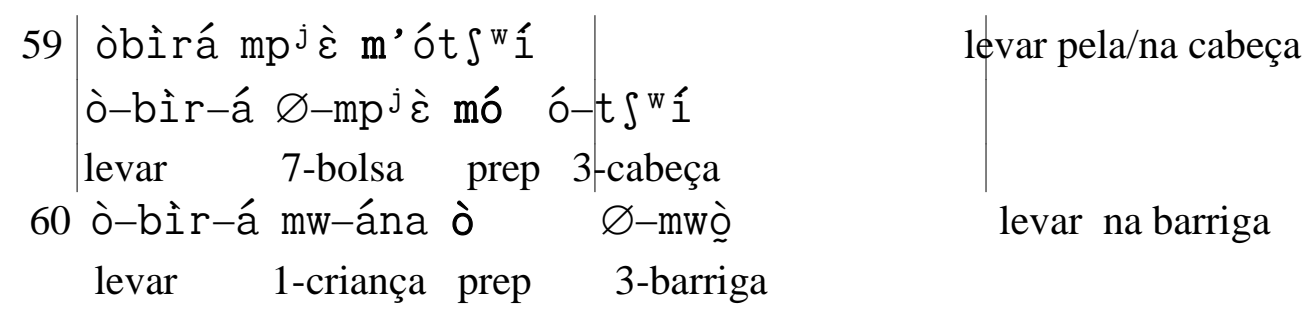

\section{2- Provérbios}

$\mathrm{Na}$ transcrição dos provérbios, da fábula e do conto, daremos na primeira linha (L1)o enunciado em lembaama, na segunda linha (L2), a segmentação morfológica; na terceira (L3), faremos a descrição gramatical e a tradução dos elementos do enunciado. Finalmente, na quarta linha (L4), daremos a tradução do sentido do enunciado em português.

\section{Provérbios no presente}

\section{I.1. sem negação}

1. 11. m’ $e^{39}$ li n’o nt jó é ndz jámí

12. me / e/ li/ ya/ o /ø-nt jje /é /ø-ndz jámí

13. $1 \mathrm{sg}^{40} / \mathrm{IS} /$ estar/aqui/ em/ 7-terra / de/ 1 - Deus

14. 'Estou na terra de Deus: ela pertence a todo mundo'

2. 11. maam'asó, o monó ya ndz jámí 'tudo depende de Deus'

12. maami/asó / o / monớ/ ya / ø-ndz jámí

13. 6-coisas/ todas/ IS / ver / com/ 1- Deus

14. 'Quem decide, é Deus: tudo depende de Deus'

\section{I.2. com negação}

1. 11.maam’ obí ka jkwóno kalí ní

12. maami / obí/ ka/ ø-nkwónơ/ kalí / ní

13. 6-coisas/ ruim/Neg/ 7-família /não /Neg

14. ' chatice não significa falta de parentes. Isto é, apesar de ter família, a pessoa pode ser ruim'

2.11.okáás' a dze, a ka dzá lesóró le nama ní

12.o-káásí/ a / dze/ a / ka/ dzá / le-sóró/ le/ ø-nama / ní

13. 1-mulher/ IS / ir / IS / Neg/ comer/9-figado / de / 1- animal / Neg

14. 'a mulher que vai-se embora, não vai comer o fígado da caça. Isto é, ela estará ausente no bom momento.'

\footnotetext{
${ }^{39} \mathrm{Na}$ transcrições notamos apenas o tom alto. Como a língua tem dois tons (alto e baixo), na ausência do tom alto, temos o baixo.

${ }^{40}$ Abreviações: IS: índice sujeito sg: singular $\quad$ pl: plural $\quad$ IO: índice objeto Neg: negação Hab: habitual loc: locativo Imp.: imperativo P.A .: Prefixo do Adjetivo Ideo: ideofone Con: conectivo 


\section{Provérbios no passado}

\section{II.1. sem negação}

1. 11. ndz jám’á sứmbí báári m’ékwú

12. ø-ndz ${ }^{j}$ ámí/ a / sứmbí / bá-árí / ma /é-kw

13. 1-Deus /IS / criar-pass / 2 -pessoas/ por/ 4 -costumes

14. 'As pessoas são viciosas por natureza. Isto é, não me censurem por nada. A culpa não é minha.'

2. 11. sáábé lé sứmb’ $a k^{j}$ ' o mpár’ é ndz ${ }^{j}$ ámí

12. sáábé/ lé / sứmbî́ / a-kª / ó / ø-mpárîl é / ndz jámí

13. $1 \mathrm{pl} \mathrm{/} \mathrm{IS} \mathrm{/} \mathrm{fabricar-pass/} \mathrm{8-redes/} \mathrm{com/} \mathrm{7-força} \mathrm{/} \mathrm{de/} \mathrm{Deus}$

14. 'Fizemos as redes graças à força de Deus. Isto é, a sabedoria dos velhos vem de Deus'

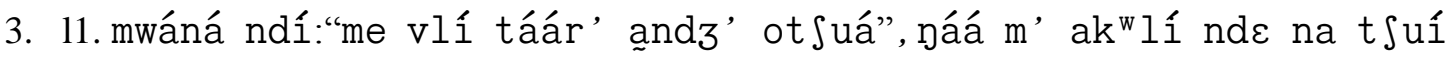

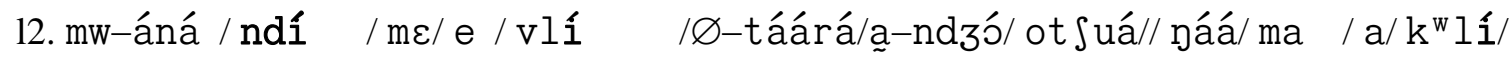

13.1-criança/dizer-pass/1sg/ IS/ ultrapassar-Pass/1-pai/ 8-casas/construir// mas/aquela/IS/ parir-pass/

12. nde/na /a / t Juí

13. $3 \mathrm{sg} /$ quem /IS / construir-Pass

14. O filho disse: 'construí mais casas que meu pai. Mas quem construiu aquela onde ele nasceu? Isto é, nunca se deve menosprezar os velhos'

\section{II.2. com negação}

1. 11. m’é ló nî kwóró, ka mé járí ní

12. me /é / ló /ní / kwóró / ka / me /é /járí / ní

13. 1sg/ IS/ pôr-pass/apenas / 12-braço/ Neg / 1sg / IS /pegar-pass/ Neg

14. 'só pus o braço, não peguei. Isto é, só perguntei, não pretendo faze-lo'

\section{II.3.Provérbios com presente + passado}

1.11. ot ${ }^{w} 1$ ró lwóró mvuur' a ndé rá móní

12. o-t Jwíl /ó / Ø-lwóró / mv-uuru / a / ndé / á / móní

13. 3-cabeça/IS /7- sonhar / 1- pessoa / que/3sg / IS / ver-pass

14. 'a cabeça só sonha com quem ela viu. Isto é, pensa-se primeiro em quem encontramos'

2.11.mpur’akaas'elíbí, abalar'elíbí, ojérí ggwurá me, mvuur'a mpí m’opiri bla lent Júrú

12. Ø-mpuru/ a-kaasí /e-líbí /a-balara / e-líbí //o-jérí / /Ø-ygwurú/ a/ me

13. 7- vila / 8- mulheres / 4-bandidas/2-homens / 8-bandidos// 12-inteligente/7-plantação/ de/ 1sg

12. mv-uuru / a / mpí /me / o-piri /bla / le-ntsúrú

13. 1-pessoa / IS / dar-Pass / 1sg /3- vegetal/com /9- fruta

14. 'Numa vila onde as mulheres são bandidads, os homens bandidos, é inteligente minha mãe, a que me deu mandioca e frutas. Isto é, ela cuida de mim. Sem ela não haveria ninguém'

\section{II.3.1. na forma negativa}

1.11. me ri dze bla n’okó ní,me nde ro ma ré sá

12. me / ri/ dze/ bla/ na/ o-kó/ ní/ me/ nde/ ó / ma / e/ sa

$13.1 \mathrm{sg} / \mathrm{neg} / \mathrm{ir} / \mathrm{com} / \mathrm{com} / 1$-sogro/neg/ $1 \mathrm{sg} / 3 \mathrm{sg} / \mathrm{o}$ que /que / IS/ fazer

14. 'por que não posso ir com meu sogro ? O que que eu faria para ele ?

Isto é, não ganho nada brigando com ele’ 


\section{II.4. Provérbios com passado + presente}

1.11.angkaam’avwúlí mwórí mó sasi, mpure mvưúr'odze mó tírá jkwóno

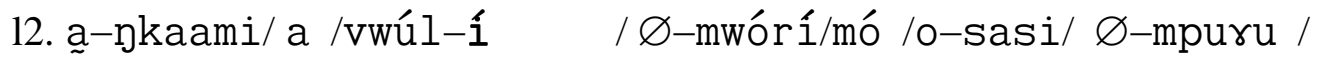

13. 2-formigas/ IS / atravessar-pass/ 1-rio /loc /12-corda/ 7-vila /

12. e /mv-uúru/ o / dze / mó / o / tírá / Ø-nkwóno

13. de/1-pessoa / IS/ ir / com / IS / falar /7-família

14. 'formigas atravessaram o rio graças a uma corda, só se pode entrar na casa de alguém falando com um parente dele. Isto é, nunca se pode esquecer que há intermediários'

\section{Provérbio expressando o habitual}

\section{III.1.Habitual sem negação}

1. 11. m’ákwaa báári, m’ásiilaa báári

12. ma / á / kw-aa / bá-ári / ma /á /siil-aa/ bá-ári

13. quem / IS / morrer-Hab/2-pessoas/ quem/IS / ficar- Hab/2-pessoas

14. ' nasce gente, morre gente e a vida continua'.Isto é, há sempre gente na terra.

\section{III.2.Habitual com negação}

1. 11. ndz jám’á ka dziáá bîíla ní, nd’ó dz’étímá

12. Ø-ndz ámî/ a/ ka/ dzi -áá / bîíla/ nî / ndé/ o/ dzá/ é-tîmá

13. 1- Deus / IS/ Neg/ comer-Hab/4-comida/ Neg/ 3sg/ IS/ comer/4-corações

14. 'Deus quer homens, não quer oferendas deles (que são destinadas aos antepassados)'

\section{IV.Provérbios no futuro ${ }^{41}$ do subjuntivo}

\section{IV.1. sem negação}

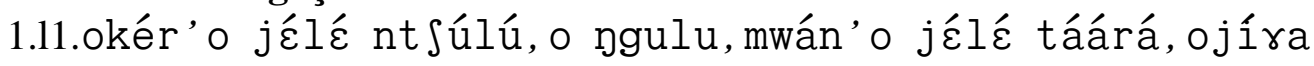

12.o-kérí / o / jélé / Ø-nt Súlú / o-ggulu / mw-áná /

13. 3- rio / IS / faltar / 7-nascente / 3- lago / 1- criança/

12. o / jélé / Ø-táárá / o-jíra

13. IS/ faltar / 1- pai / 12- escravo (a)

14. 'um rio sem nascente é um lago, uma criança sem pai, um escravo. Isto é, ele(a) será infeliz'. Seria algo como 'se um rio não tiver nascente, é um lago. Uma criança que não tiver pai será escravizada'

2.11. okwi ro lo kalírí pkwés'o sá buni

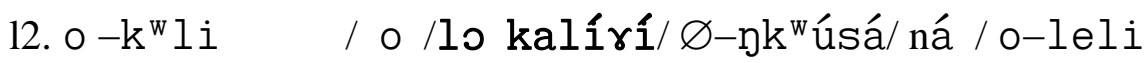

13. 1-mãe biológica/ IS / abandonar /7- abandono / com/ 1-babá

14.'se a mãe biológica abandonar, imagine o que poder acontecer com a babá!? Isto é, nada vale a mãe '

3. 11. oburá na táárá we na ngwúrú

12. o-burá / na / Ø-táárá / we / na / Ø-ygwúrú

13. 12 -amizade / com/ 1- pai /2sg / com/ 1-mãe

14. 'amizade com o pai enquanto tiver uma mãe. Isto é, você é bem tratado graças a ela'

\footnotetext{
${ }^{41} \mathrm{O}$ futuro pode também ser expresso pelo presente. Isto é, pela ausência de marcas de tempo.
} 


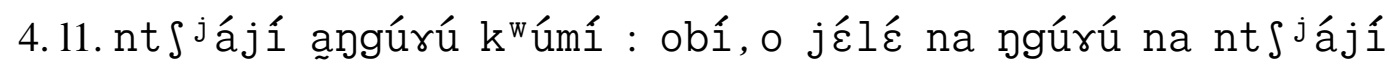

12. Ø-nt jájí / a-ngúrú / kwúmí/ o-bí / o /jélé / na /

13. 1-órfão / 2-mãe / dez / 11-feiura / IS / faltar / com /

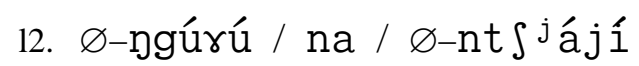

13. 1- mãe / com/ 1-órfão

14. 'o órfão tem dez mães: se o mal não vier das mães virá do órfão. Isto é, ele é ruim por que há muita gente para cuidar dele'

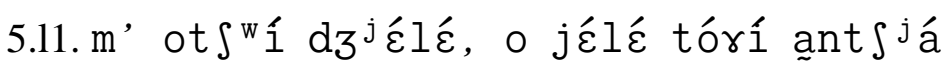

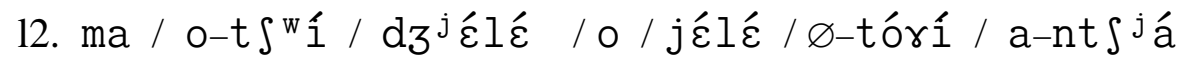

13. loc / 3-cabeça / dois / IS / faltar / 7-sangue / 8- lágrimas

14. 'na cabeça há duas coisas: se não for sangue são lágrimas. Isto é, com ventosas, ou tira-se sangue e a gente fica curado, ou então a gente morre e então, há lágrimas’

6.11.lekwú le kísá ngwúrú, a lil’ a wí

12.le-kúúle / kísá / Ø-ngwúrú / a-lili / a / wí

13.9-morte / IS / enganar/ 1- mãe / 2-chorões / IS / acabar

14.'se a morte não encontrar a mãe, não haverá mais chorões. Isto é, se a mãe não falecer, ninguém vai chorar'

7. 11. nkér' o láámá, w’ o jós' akó, bî́íla m’ olúmá ndé

12. Ø-pkérí/o /láámá / we / o / jósó / a-kó / bîíla /mó /o-lúmi/á /nde

13. 1-irmã /IS / cozinhar/ 2sg / IS / cozinhar/ 7-bananas/4-comida/Con-de/1-marido/Con- de/ 3sg

14. 'quando a sua irmã for cozinhar, e se você cozinhar bananas, a comida é do marido dela. Isto é, é preciso que os membros de uma família se ajudem entre eles'

\section{IV.2. com negação}

1.11. ndz jám'otumá mvưúru ndzilá nd'ó búún' obsá j’ó mpárí ní

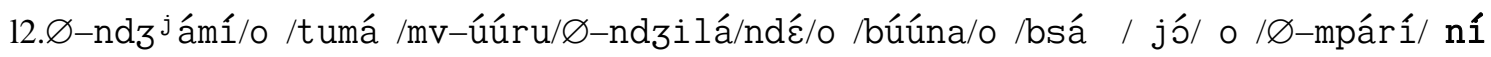

13. 1- Deus /IS /mandar/1-pessoa /7-caminho /3sg /IS/ poder /IS / recusar/I.O/ pela / 7- força /Neg

14. 'Se Deus mandar alguém fazer algo, a pessoa não pode recusar pela sua própria força. Isto é, não se pode resistir a Deus'

2. 11. táár'o kº́ wo líl' abur' a táárá, k’a we ní

12. Ø-táárá / o / kwá / we / / líl-1̂ / a-burá / a/ Ø-táárá / ká / a / we / ní

13. 1- pai / IS / morrer/ 2sg/IS/ chorar-pass/ 2-amigos/de/ 1-pai / / Neg/ de / 2sg / /Neg

14. 'se seu pai falecer, chore pelos amigos dele, não chore pelos seus. Isto é, os amigos do seu pai não são seus.'

3.11.okar ó sébé ndzal' olúmí, obol' o nd' ánkúlú ka molúmí ní

12.o-karí /ó / sćbé / Ø-ndzala / o-lúmí / o-bolo / o/ ndé/

13.1-esposa / IS / rir /7-fome / 1-marido/1-preguiça/de/3-sg /

12.ankúlú / ka / mo / o-lúmí / ní

13. mesmo (a) / Neg / de / 1- marido/ Neg

14. 'a mulher que rir da fome do marido, ri da preguiça dela mesma. Isto é, ela puni a se mesma' 
4.11.w'o mon'okwúúrú n’amvu, wo mpí nd’ atîbí, amvú máá ko jérí ní

12. we / o / mono /o-kwúúrú / ga / a-mvu / we / o / mpí /

13. 2 sg / IS / ver / 1- velho / com / 6- cabelos broncos/ 2sg / IS / dar- subj/

12. ndé/ a-tîbí / a-mvú / máá / ka / o-jérí /ní

13. 2sg/ 8-conselhos/ 6-cabelos brancos/Neg / 11-inteligência/ Neg

14. 'se você encontrar um velho de cabelos brancos, dê-lhe conselhos: aqueles cabelos brancos não são sinônimo de sabedoria. Isto é, os mais velhos também podem ser aconselhados'

\section{Provérbios no futuro do subjuntivo + imperativo}

\section{V.1. sem negação}

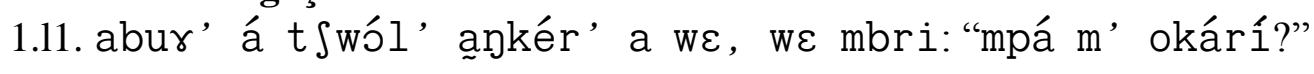

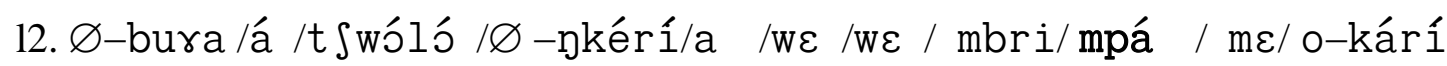

13. 1-outro /IS /cortejar /1-irmã /con-de /2sg /2sg /dizer / Imp-dar/ 1sg/1-mulher

14. 'Se outra pessoa cortejar a sua irmã, será que você vai dizer: "dê-me a mulher ?" Isto é, um jovem que corre atrás das mulher é infeliz e nunca casar-se-á.

\section{V.2. com negação}

1.11.nt jáj’’o sííla bla we, w’o mpí ndé biila, ka mpáá ndé maami ní 12.Ø-ntsjájí/o /sííla /bla /we // we / o / mpí / ndé /biila //

13. 1-órfão /IS / morar /com / 2sg / 2sg / IS / dar-Imp/3sg /4-comida //

12. ka / mpáá /ndé /maami/ ní

13. Neg/ dar - Imp./ 3sg / 6- coisas/ Neg

14. 'se deixarem um órfão contigo, dê-lhe comida. Não lhe dê lenga-lenga! Isto é, é uma regra de solidariedade. Não prejudique-o!'

\section{V.3. com negação + habitual}

1.11.we na mwáná jkérí, ka turáá ggúrú balara ní

12. we / na / mw-ánánkérí/ ka / tur-áá /Ø-ngúrúbalara / ní

\section{2sg/ com/ 1- sobrinho / Neg/insultar-Hab/ 1- tio / Neg}

14.'se você tiver um sobrinho, não tenha costume de insultar o seu tio. Isto é, você pode ser a próxima vítima'

\section{Provérbio no imperativo presente + presente do indicativo com negação}

1.11. dzá, odzá ro we, obárá bárî k’on’ové ní

12. dzá / o-dzá / o / we // o-bárá / ka /o-nª́ / o-vé / ní

13. comer-Imp./ comer / con-de / 2sg// receber / Neg / 3-boca / 3- bom / Neg

14. 'coma sua própria refeição; se isso for o que recebeu, a boca não é boa. Isto é, só se curte realmente, aquilo que recebemos pelo próprio esforço' 


\section{3- Fábula mbaama : o ferreiro e a tartaruga}

1.11.ot ${ }^{w} 1 \hat{~}$ blá nkrú

12. o-tulí / blá / Ø-nkrú

13.1-ferreiro/ com / 1-tartaruga

14. 'O ferreiro e a tartaruga'

2.11. mvur' akiîí m’ osí. nd' ákí otulí.
12. mv-uru / a/ kíí / má / o-sí / ndé / a / kí / o-tulí

13. 1-pessoa/ IS/ ficar-Pass-Hab/ loc / 12-país/ 3sg /IS / ser-pass/ 1-ferreiro

14. 'Num país, vivia um homem que era ferreiro'

3. 11. ndé na báár' ásîíso ndí

12. ndé/ ya / bá-ári/ á-síísó / ndî

13. $3 \mathrm{sg} / \mathrm{com} / 2$-pessoas/2-todas / dizer que-pass.

14. 'Ele disse a todas as pessoas que'

4.11. ntin' é me ré twiá, m’ówóßó na mvuru ní m’ótulá pí.

12. Ø-ntini / é / me/ é/tulá/ me/ o/ wóßó/ na /mv-uru/ nî/ me/ó /tulá/ pí

13. 7-momento/ que/ 1sg/ IS/ forjar/ 1sg/ IS/ falar / com /1-pessoa/ Neg/ 1sg/ IS /forjar/quieto 14. 'quando forjo, não falo com ninguém. Forjo quieto'

5.11. nguj' ódzí na nkóso, nd’ ót ${ }^{w} l i ́$ nguj’ ó vríri.

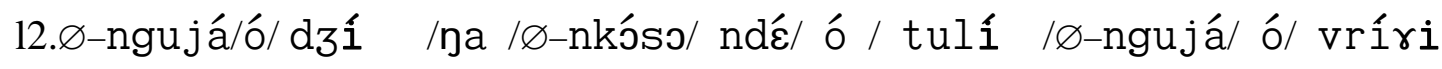

13.1-javalí /IS/ vir-pass/com/7-ferro /3sg /IS /forjar-pass/1-javalí / IS/ voltar-pass

14. 'o jabalí trouxe o ferro, ele forjou. O javali voltou'

6. 11. bimb’ódzí na nkóso nd’ótwií pí, nd’ówóßó ní.

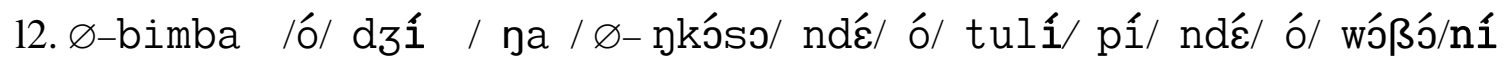

13.1-antelope1 /IS/ vir-pass/ com/ 7-ferro / 3sg / IS/ forjar-pass/ 3sg / IS / falar / Neg

14. 'O antelope1 trouxe o ferro, ele forjou quieto, ele não falou'

7. 11. osb’ódzî́ aykóso, nd' ótwlî́ pî, nd’ówóßjó nî.

12.o-sibí / ó /dzî́ /na /Ø-nkóso/ndé/ ó/tulî́ / pî́ / ndé/ ó/ wóßó/ nî

13.12-antelope2/ IS/ vir-pass/ com/ 7-ferro / 3sg/ IS/ forjar-pass/quieto/3sg/ IS/ falar / Neg

14. 'O antelope2 trouxe o ferro. Ele forjou quieto, ele não falou'

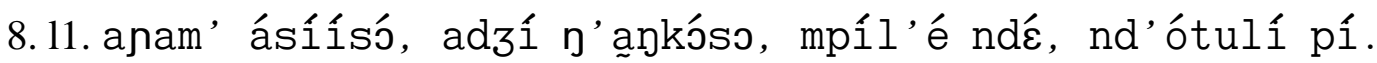

12. a-nama/á-sísó/a/ dzî́ / pa/ a-Đkóso/ mpîlî́/ é/ ndé/ ndé/ ó/tulí/ pí

13.2-animal/2-todos/IS/vir-pass/com/8-ferros/loc /con.-de $/ 3 \mathrm{sg} / 3 \mathrm{sg} / \mathrm{IS} /$ forjar-pass/ quieto

14. 'Todos os animais trouxeram ferros para ele. Ele forjou quieto'. 
9. 11. nd’ówóßó ya bó ní.

12. ndé/ ó/ wóßó/ ná / bó / ní

13. $3 \mathrm{sg} / \mathrm{IS} / \mathrm{falar} / \mathrm{com} / \mathrm{3pl} / \mathrm{Neg}$

14. 'ele não falou com eles'

10.11. pa mba, t túrú le mó, jkrú odzí ya jkóso mó ntú, mpil'ótulí.

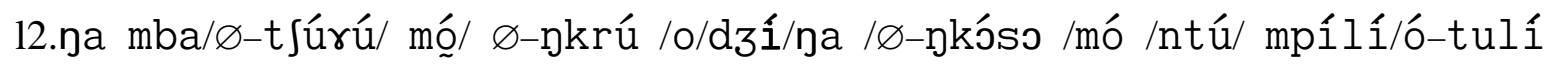

13.Então / 7-dia / um/1-tartaruga/IS/ vir-pass/com/7-ferro/ um/ só / loc. /1-ferreiro

14. 'Então, um dia, a tartaruga trouxe um ferro só para o ferreiro'

11.11. pkrú ya ndé ndí w’otulá m’ówúnú, w’otulá me ropímí

12. Ø-pkrú / pa/ ndé/ ndí /we /ó/tulá /me /o-wúnú /we /ó/tulá /me/o-pímí

13. 1-tartaruga/com/3sg/dizer-pass/2sg/IS/forjar-subj/1sg/7-machado/2sg/IS/forjar-subj/1sg/7-enxada

14. 'A tartaruga disse a ele: me forje um machado e uma enxada'

12.11. w'otwlá me ndzuú, w’otwlá me ggmá, w’otwlá me sórí,

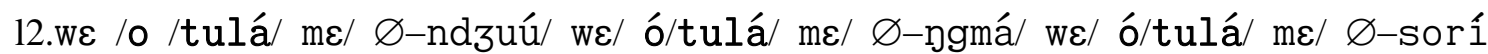

13.2sg/IS/forjar-subj/1sg/7-panela/2sg/IS/forjar-subj/1sg/7-facão /2sg/ IS/ forjar-subj/1sg/ 7-agulha

14. 'me forje uma panela, me forje um facão, me forje uma agulha'

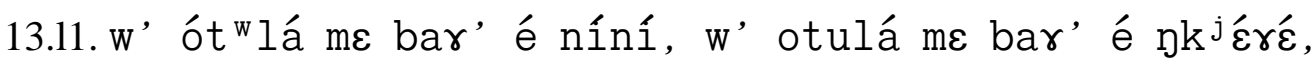

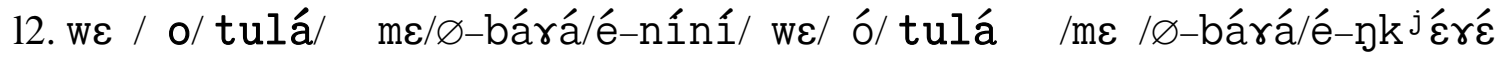

13.2sg/IS/forjar-subj/1sg/7-faca/P.A-grande/2sg/IS/forjar-subj/1sg/7-faca / P.A-pequena

14. ' me forje uma faca grande, me forje uma faca pequena'

14.11. w’ otulá me ndzuú á káá

12. we / o/tulá / me/ Ø-ndzuú/á la-káá

13. 2sg/ IS/ forjar-subj/ 1sg/ 7-panela /con.-de/ 8-tabaco

14. 'me forje um cachimbo'

15.11. na mbaa, otwl'ó késí jkrú pubúbú.

12. na mbaa/ o-tulí / ó / késí / Ø-nkrú / pubúbú

13. Então / 1-ferreiro / IS / olhar-pass / 1-tartaruga / ideo ${ }^{42}$

14. 'Então, com grande surpresa, o ferreiro olhou para a tartaruga'

16. 11.ot' l’ákan' ás jélí.

12. o-tulí/ a-kaní / á / sjélí

13.1-ferreiro/ 8-recursos / IS / parar-pass

14. 'O ferreiro não sabia o que fazer'

${ }^{42}$ Ideofone que indica a surpresa 
17. 11. ndé na Đkrú ndí Đkós’ é we dzi, ti mơ ntú,

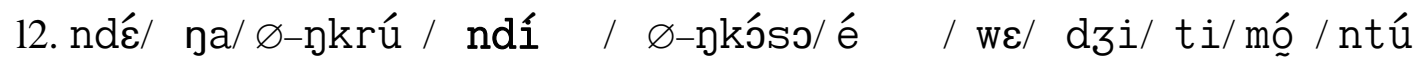

13. $3 \mathrm{sg} / \mathrm{com} / 1$ - tartaruga/ dizer-pass/7-ferro /con-de/2sg/ este/é /um / só

14. 'Ele disse para a tartaruga que: este teu ferro é um só'

18. 11. we mbri m’ ét "lá w' owúnú ,

12. we / mbri/ me/ é / tulá / we / o-wúnú

13. $2 \mathrm{sg} /$ dizer /1sg / IS / forjar-subj / 2sg / 7-machado

14. 'você quer que eu te forje um machado'

19. 11. na ropíímí, na dzwó, na ygmá, na sorí, Đ’ a bárá muélé,

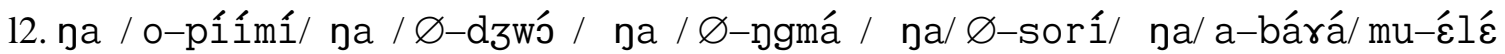
13.com/7-enxada / com / 7-zagaia / com / 7-machete/ com/7-agulha/ com/ 8-faca / 8- duas 14. 'com uma enxada, uma zagaia, um machete, uma agulha, duas facas'

20.11. ja nd3w' á káá,

12. nà / Ø-ndzuú / á / à-káá

13. com / 7-panela / con-de / 8-tabaco

14. ' com cachimbo'

21.11. bjá bîî́b' ésíísó m’ ot "lá we dzó búni

12. bjá / biibí/ e-síísó/ me / ó / tulá / we / dzó / búni

13. aquelas/4-coisas/4-todas /1sg / IS / forjar-subj/ $2 \mathrm{sg} /$ elas / como

14. 'como você quer que eu te forje tudo isso ?'

22.11. jkrú pa ndé ndí me dưí we vuá, mbaa, mé jưî́ ndî́,

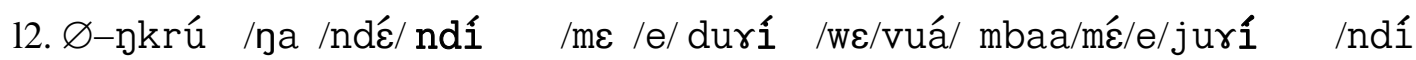

13. 1-tartaruga/com /3sg /dizer-pass/1sg/IS/ dizer-pass/2sg/isso/porque/1sg/IS/ouvir-pass/dizer que

14. 'A tartaruga disse para ele: ' te disse isso porque ouvi dizer que'

23.11. w’ á ka wóßóó na báári ní

12. we / á / ka / wóßóó / pa / bá-ári / ní

13.2sg / IS / Neg / falar-Hab / com / 2-pessoas / Neg

14. 'você não costuma falar com pessoas'

24. 11. yá w’ omí wóßó dzaa lé mí wá

12. ná / we / o / mí / wóßó / dzaa / lé / mí / wá

13. mas / 2sg / IS / pass/ falar / 4-problema/ IS / pass / acabar

14. 'Mas como você já falou, acabou o problema' 
ANEXOS 
Classificação genética das línguas africanas do tronco Nigero-Congolês ao grupo banto

(cf. Williamson \& Blench, 2000)

Williamson \&

Blench 2000;

Schadeberg

2003

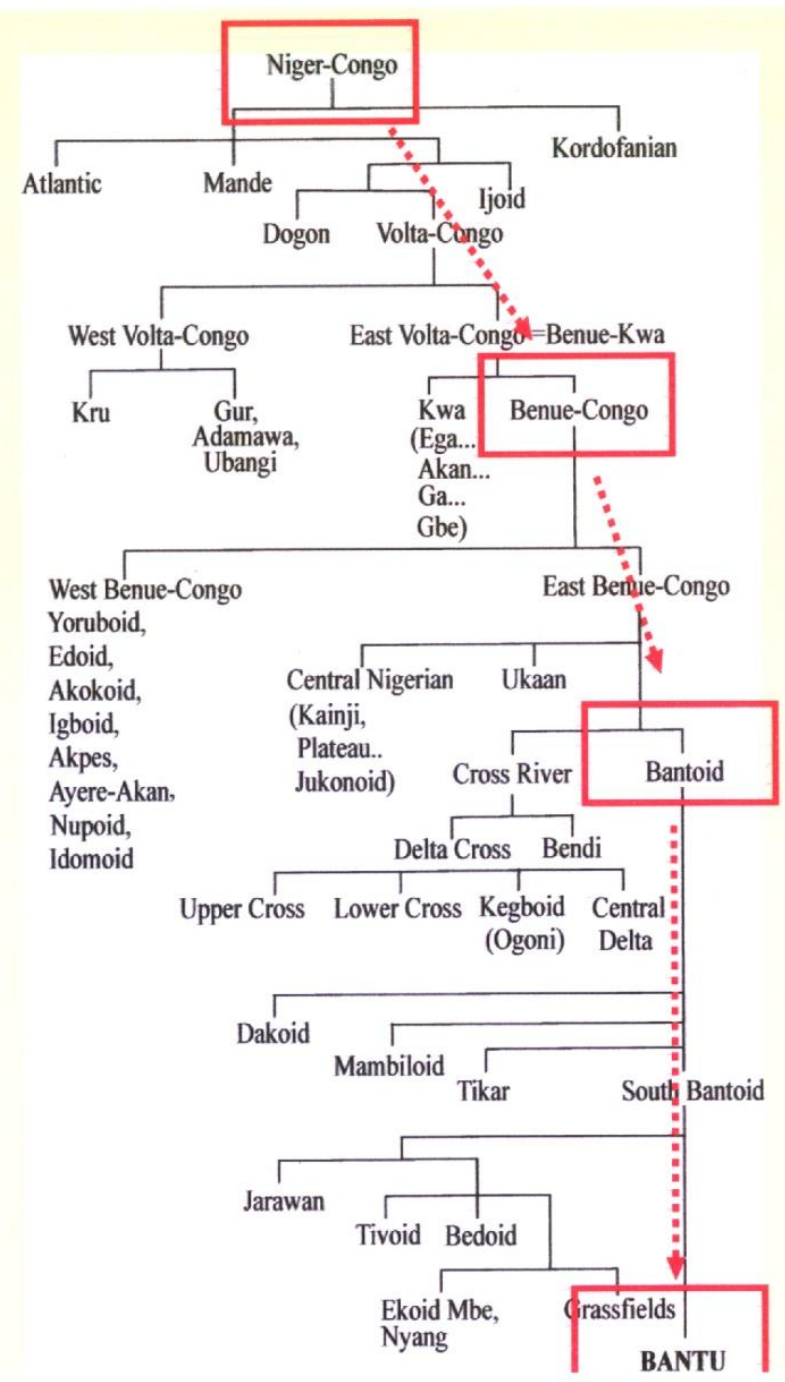




\section{MAPAS}

\section{(1) MAPA DAS LÍNGUAS DA GRANDE FAMÍLIA NIGERO-CONGOLESA}

(cf. Williamson \& Blench, 2000)

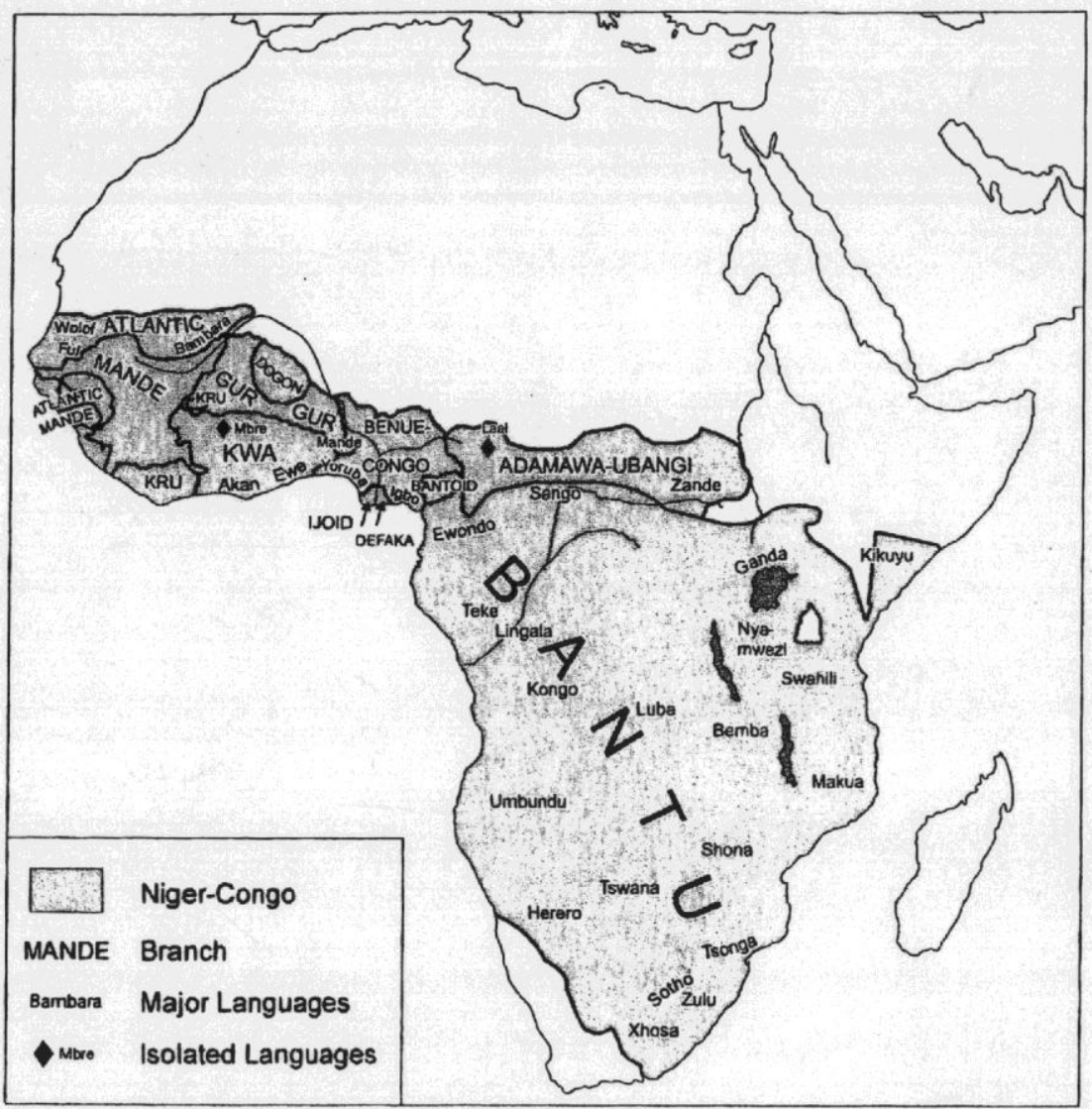

Map 2.2. Niger-Congo. 
(2) Mapa que apresenta o grupo Benuê-Congo e seu subgrupo Banto (cf. Nurse \& Philippson, 2003:2)

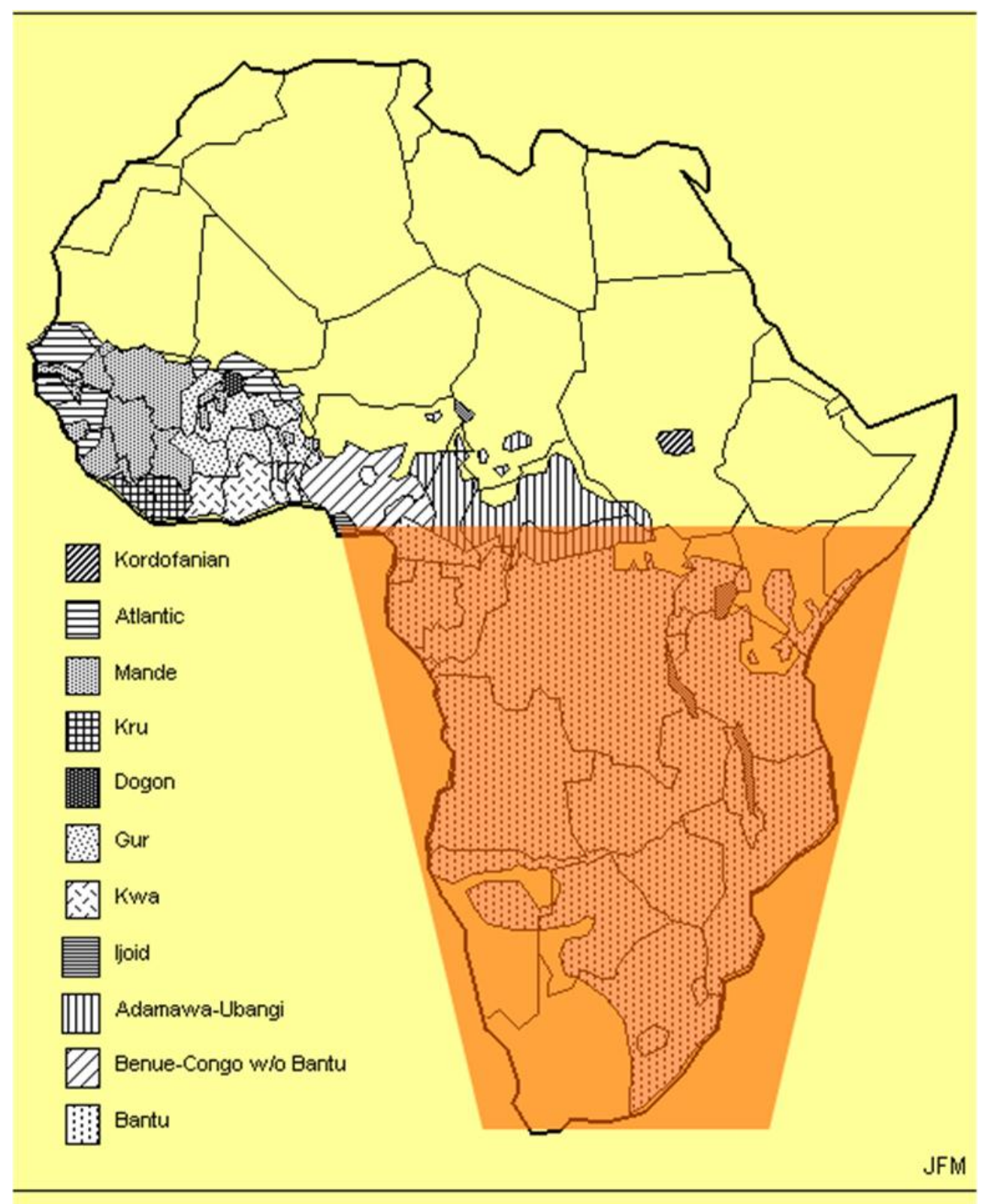


(3) LÍNGUAS BANTAS CLASSIFICADAS EM GRUPOS (cf. Yvonne Bastin, 1978)

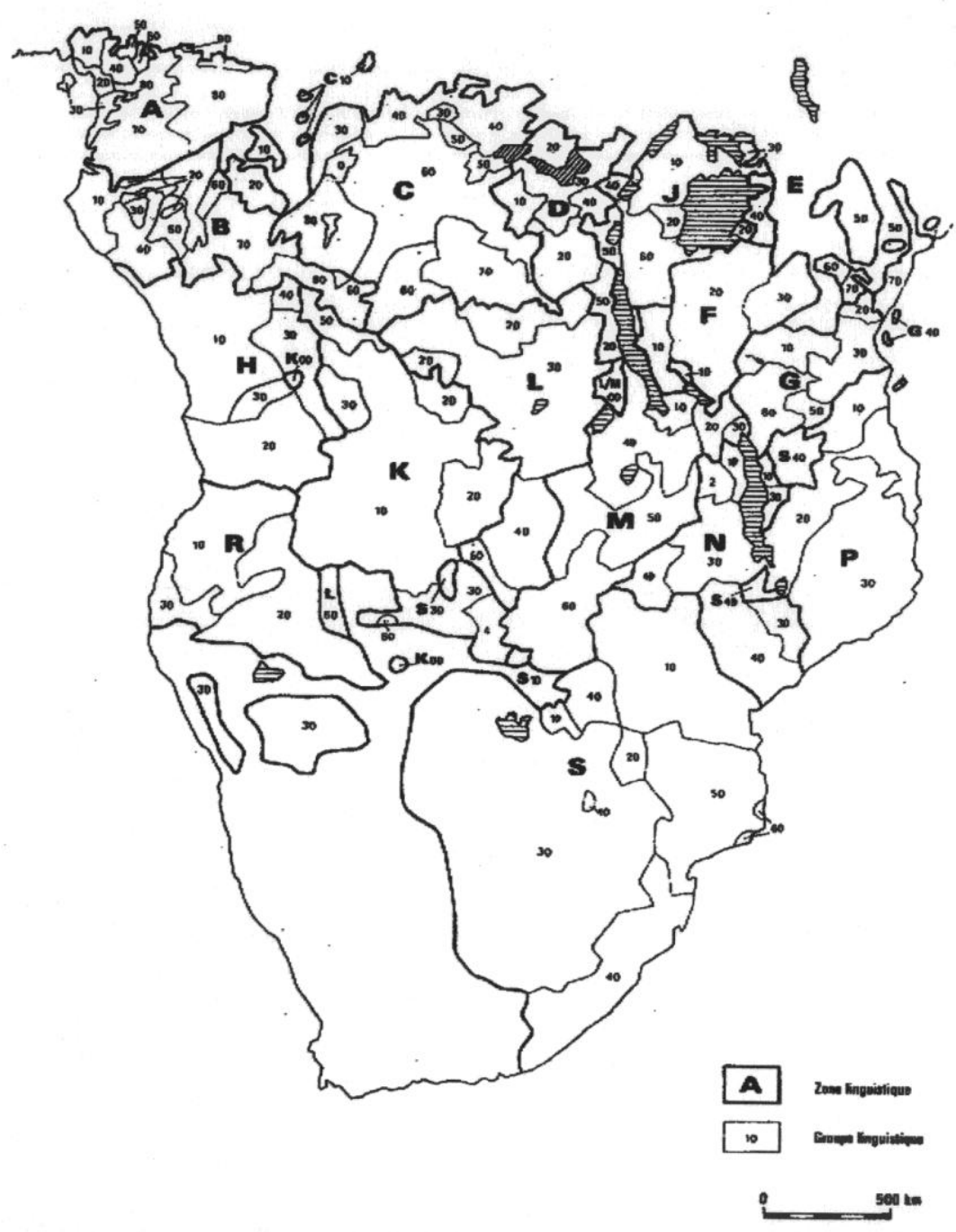


(4) PRINCIPAIS LÍNGUAS BANTAS DA FLORESTA

(cf. Claire Grégoire, 2003)

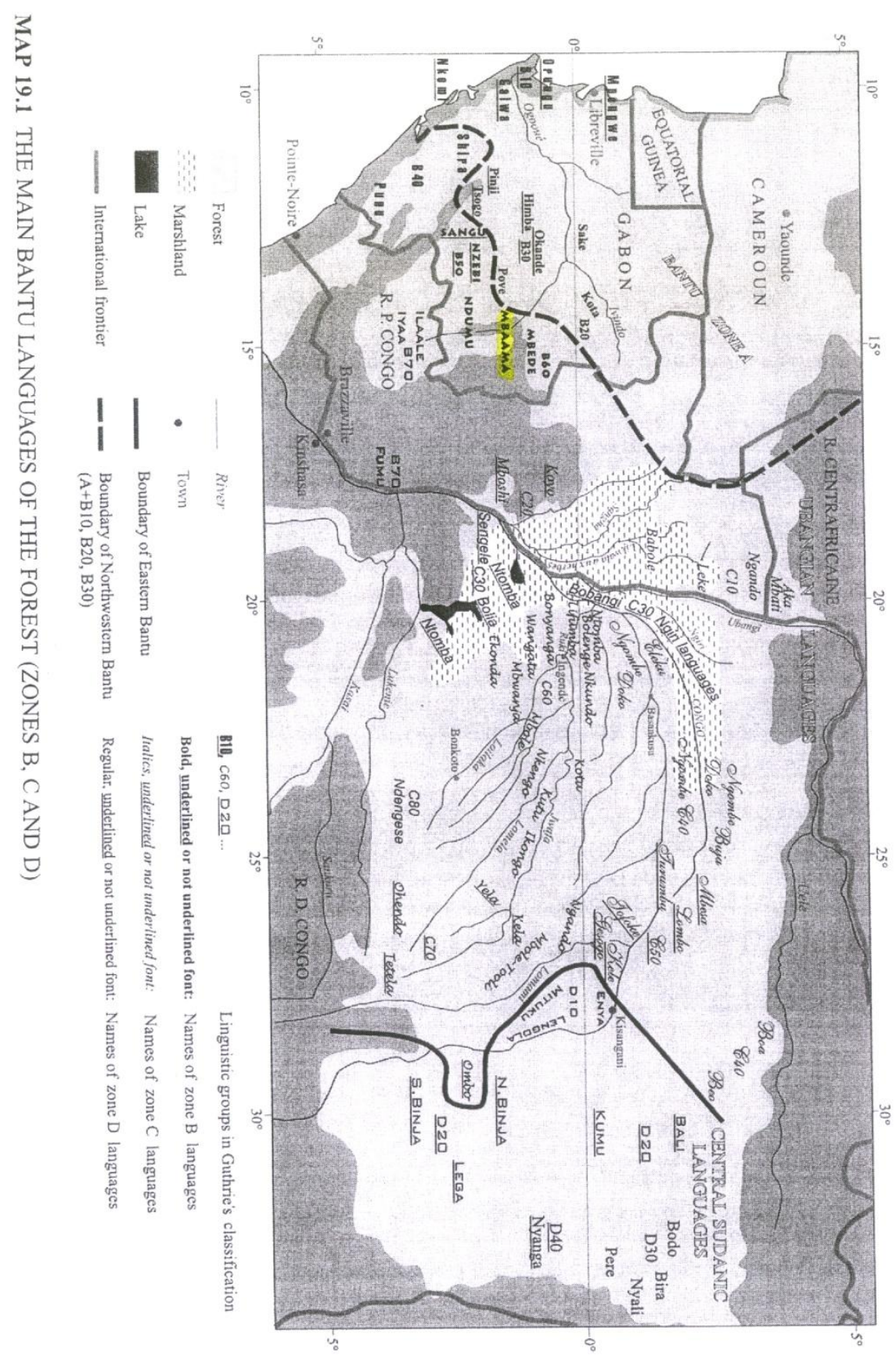


(5) PRINCIPAIS LÍNGUAS DO GABÃO (cf. Michel Voltz,1989)

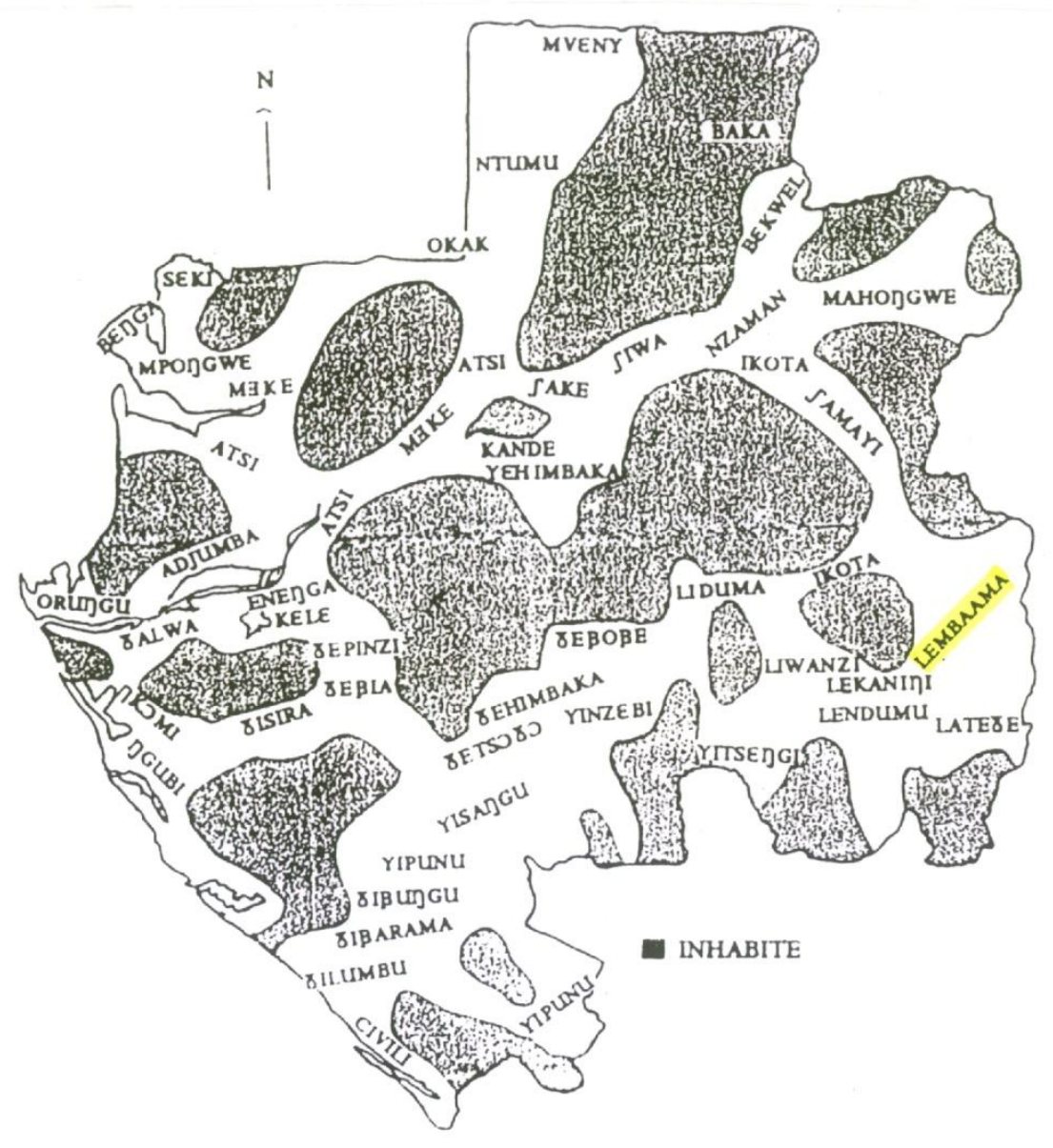

